\title{
The City of Shadows
}

by

Alexandra Blanchet

A thesis submitted to the Faculty of Graduate and Postdoctoral Affairs in partial fulfillment of the requirements for the degree of

Master
in
Architecture

Carleton University

Ottawa, Ontario

(C) 2017

Alexandra Blanchet 


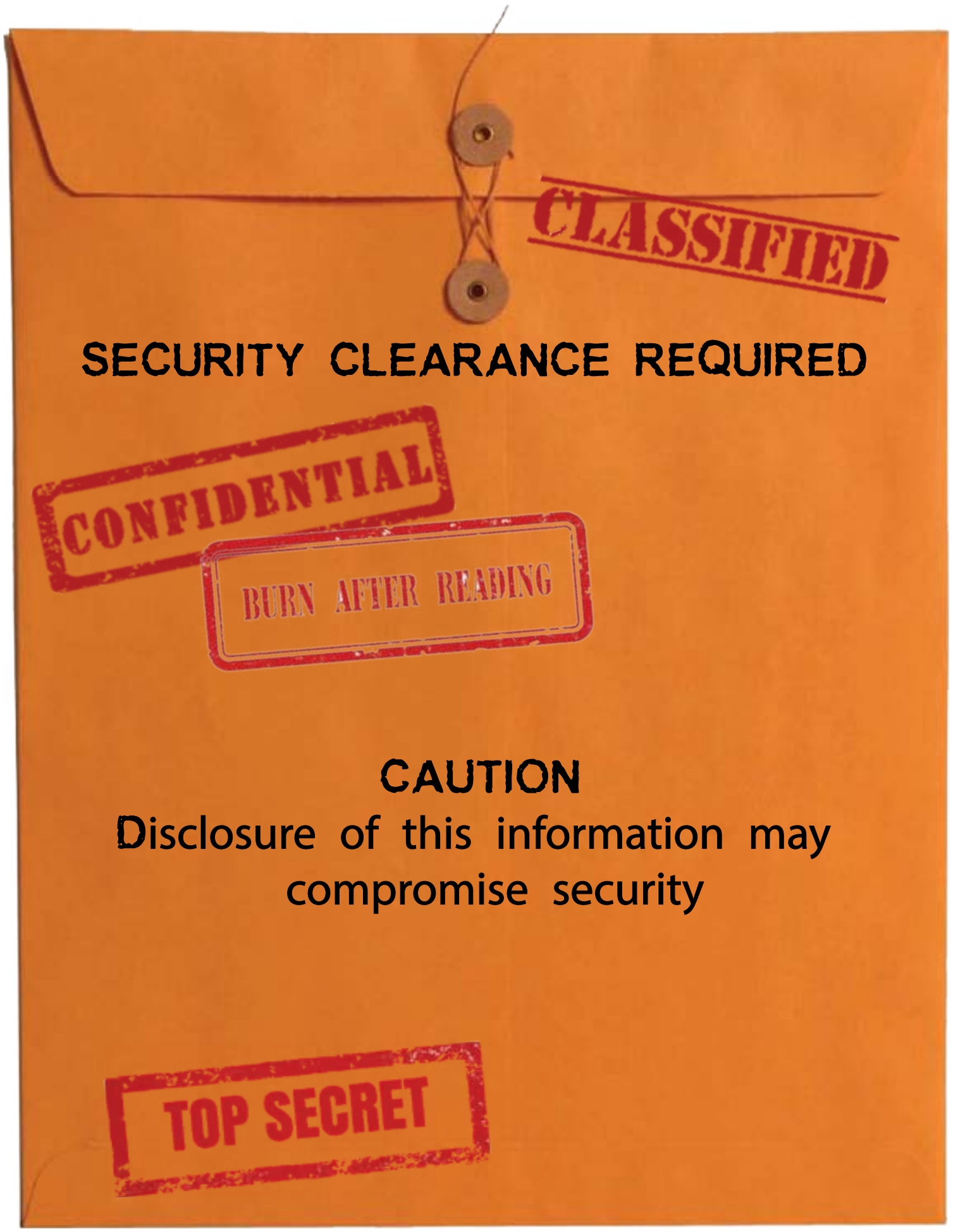




\section{Confidentiality Agreement}

This CONFIDENTIALITY AGREEMENT is made by and between

Sandra Blanche AND

Special Recruit

By signing this document, the Recruit agrees to a total non-disclosure and shall imperatively destroy these documents after reading. Should the Recruit disagree and refuse to sign this agreement before reading they will prosecuted to the full extent of the law.

I have read this document and agree:

Signature:

Full name:

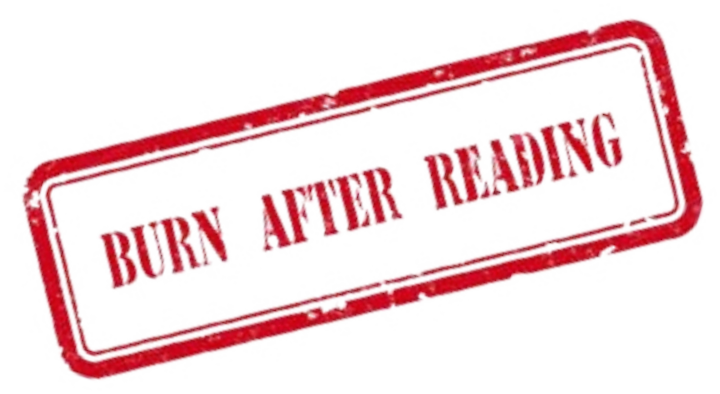




\section{Québec :}

April 1 ${ }^{\text {st }}, 2017$

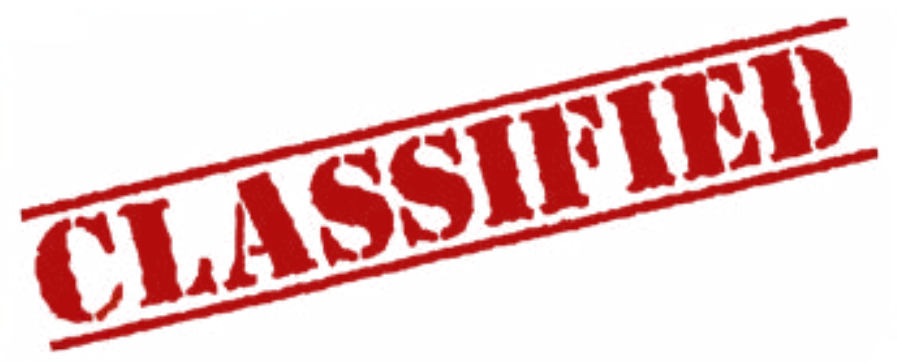

Azrieli School of Architecture and Urbanism

File Number 100904328

Carleton University

202 Architecture Building

1125 Colonel By Drive

Ottawa, Canada

K1S 5B6

This document contains confidential information and is intended only for the individuals named. If you are not the named addressees, you will be prosecuted for unauthorized access to secret information. A French version of this letter follows.

\section{Object: The City of Shadows - Final report}

Dear members of the Faculty,

As requested by Mister Yvan Cazabon, Associate Director and Associate Professor at Carleton University, please find enclosed documents of the most importance. Above all, we wish to acknowledge Professor Cazabon's tenacity and perseverance in regards to obtaining these documents; his irrefutable arguments convinced us to share our information with you and establish a partnership with your institution.

We are part of Ltd., an organization sponsored by the government to conduct studies on interprovincial affairs. You accepted to be our private consultant on the City of Shadows case. The City of Shadows is a codename for an operation that we currently have ongoing at Place du Portage in Hull, Québec, on the other side of the Ottawa River. We are finally able to share these documents with you.

In introducing yourself with the current case, it should be stated that the National Capital Region has been under political, cultural and social turmoil for more than half a century. Political instabilities occurred during Pierre Trudeau's prime-ministerial election in 1968 and then the establishment of Place du Portage in Old Hull, which was meant to represent an attempt at unification with Ottawa, our riparian neighbours. Stemming from reliable sources, the recent election of Trudeau junior as head of the Liberal party leads us to believe that other closed-door interventions regarding the future of Hull are happening again, without the Ministry of Quebec being consulted. Our plans to resist the advances of the Federal expansion into Hull were in vain 48 years ago; the early acquisition of lands 


\section{Québec :}

adjacent to expropriated properties were not enough to slow down the establishment of the Portage buildings. It is our duty to consider the possibility of a ramification or detachment of the cause of this identity crisis; to consider a thesis and an anti-thesis to the project, to propose a political change.

The following study considers the historical background of both Ottawa and Hull as well as the previous consultations between the NCC and both governments.

The intent of this investigation is to reconnect elements of the existing urban fabric at key locations that the Portage Complex somehow corrupted or discontinued. Strategies related to the original design of the government buildings by Etienne Gaboury are being used in the investigative process. For the sake of this study, we focused on a particular area by the shoreline below ground, in alignment with the Place d'Accueil to propose a thesis and anti thesis strategy. This new point of connection is meant to bring the inhabitants away from a governmental setup, set a different pace in order to experience the space at a more human scale. Mediums such as collage, drawing and printmaking are being used to express this sensorial approach. Printmaking plays an important role in the representational process as it intrinsically relates to the tension between the thesis and the anti thesis.

We are convinced that the actions undertaken to reconnect la Place d'Accueil with the shoreline contribute to reconcile the people and their land, the City with its history. The architectural intervention is a critique of the governmental apparatus, how it can be seen from the inside and the outside.

You will find attached all necessary documentation in order to proceed to the analysis. We are looking forward for the Azrieli School of Architecture and Urbanism to share their final recommendations.

We trust in your discretion, at all levels.

Sincerely,

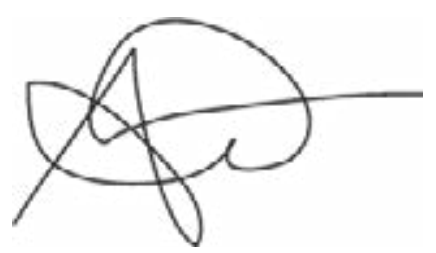

Sandra Blanche

Ramification: Ottawalnational-centrique (thèse) Ltd Détachement: Québec/provincial-centrique (anti...)

N.B. \#1 The use of both official languages in this report is relevant to express the political, cultural and social dualities because things do get lost in translation.

N.B. \#2 The non-disclosure of our organization is deliberated. Our confidentiality agreement with the government obliges us to keep some information classified in this report. 


\section{Québec}

$1^{\text {er }}$ Avril 2017

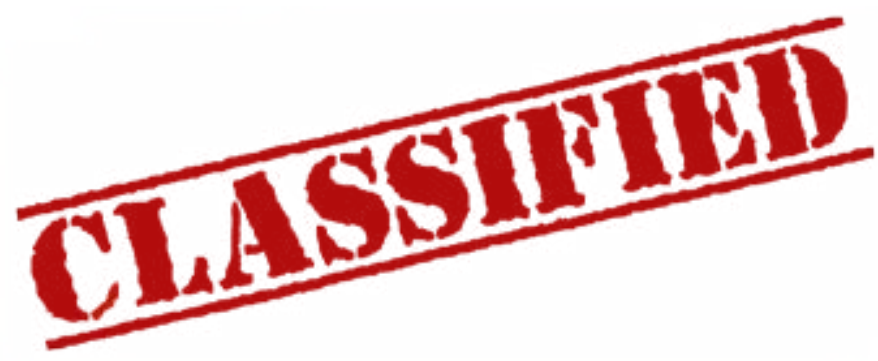

École Azrieli d'Architecture et d'Urbanisme

Numéro de dossier: 100904328

Université de Carleton

202 Bâtiment d'Architecture

1125 Promenade Colonel By

Ottawa, Canada

K1S 5B6

Ce document contient des informations confidentielles et est destiné uniquement aux personnes nommées. Si vous n'êtes pas les destinataires désignés, vous serez poursuivis pour accéder aux informations secrètes sans autorisation.

\section{Objet : La Cité des Ombres - Rapport final}

Chers membres de la Faculté,

Tel que demandé par Monsieur Yvan Cazabon, directeur associé et professeur associé à l'Université de Carleton, nous vous prions de trouver ci-joint des documents de haute importance. Nous tenons avant tout à saluer la ténacité et la persévérance de Professeur Cazabon tant qu’à l'obtention de ces documents ; ses arguments irréfutables nous ont convaincu de partager nos informations en toute confiance et établir un partenariat avec votre établissement.

Nous faisons partie de gouvernement pour mener des études sur les affaires interprovinciales. Vous avez accepté d'être notre consultant privé sur l'affaire Cité des Ombres. La Cité des Ombres est un nom de code pour une opération que nous avons actuellement en cours à la Place du Portage à Hull, au Québec, de l'autre côté de la rivière des Outaouais. Nous sommes enfin en mesure de partager ces documents avec vous.

Afin de vous familiariser avec le cas actuel, il convient de préciser que la région de la capitale nationale a subi des turbulences politiques, culturelles et sociales depuis plus d'un demi-siècle. Des instabilités politiques se sont produites au cours de l'élection ministérielle de Pierre Trudeau en 1968, puis l'établissement de la Place du Portage dans le Vieux-Hull, qui présentait une tentative d'unification avec Ottawa, nos voisins riverains. D'après de sources fiables, la récente élection de Justin Trudeau 


\section{Québec :}

comme nouveau chef du Parti Libéral nous porte à croire que d'autres interventions à huis clos se font présentement sur l'avenir de Hull, sans que le Ministère du Québec ne soit consulté.

Nos plans pour résister aux avancées de l'expansion fédérale dans Hull ont été en vain il ya 48 ans; l'acquisition anticipée de terres adjacentes aux propriétés expropriées n'a pas suffi pour ralentir l'établissement des bâtiments du Portage. Il est de notre devoir de considérer la possibilité d'une ramification ou d'un détachement de la cause de cette crise d'identité. Pour examiner une thèse et une antithèse du projet afin de proposer un changement politique.

L'étude suivante considère les antécédents historiques d'Ottawa et de Hull ainsi que les consultations antérieures entre la CCN et les deux gouvernements. L'objectif de cette enquête est de reconnecter les éléments du tissu urbain existant à des emplacements clés que le complexe du Portage a quelque peu corrompus ou abandonnés. Stratégies liées à l'originale conception des bâtiments du gouvernement par Etienne Gaboury font parties intrégrantes du processus.

Dans le cadre de cette étude, nous nous sommes concentrés sur une zone particulière au long de la rive, au niveau sous terrain. Le tout en alignement avec la Place d'Accueil afin de proposer une stratégie de thèse et d'anti-thèse. Ce nouveau point de connexion est destiné à éloigner les habitants d'une configuration gouvernementale, de proposer un rythme différent et ressentir l'espace à une échelle plus humaine. Des supports tels que collage, dessin et la gravure sont utilisés pour exprimer cette approche sensorielle. La création d'estampes joue un rôle important dans le processus de représentation, car elle se rattache intrinsèquement à la tension entre la thèse et l'anti-thèse.

Le rapport prend en considération le contexte historique des villes d'Ottawa et de Hull ainsi que les consultations entre la NCC et les gouvernements provinciaux et fédéraux. Le but de cet enquête est de reconnecter les éléments existants du tissu urbain aux endroits clés du Complexe du Portage ; celui étant corrompu et discontinué. Les stratégies urbanistes d'Étienne Gaboury pour la conception originale des bâtisses gouvernementales sont utilisées dans le cadre du processus.

Ramification: Ottawalnational-centrique (thèse) Détachement: Québec/provincial-centrique (anti...) 


\section{Québec :}

Nous sommes convaincus que les actions entreprises pour reconnecter la Place d'Accueil avec son rivage contribuent à reconcilier les habitants avec leur terre, la ville avec son histoire. L'intervention architecturale est une critique de l'appareil gouvernemental, comment il est possible de l'observer de l'intérieur et de l'extérieur.

Vous trouverez ci-joint toute la documentation nécessaire afin de procéder à l'analyse. Nous attendons hâtivement à ce que l'école Azrieli d'Architecture et d'Urbanisme partage avec nous leurs recommandations finales.

Nous avons confiance en votre discrétion, à tous prix.

Cordialement,

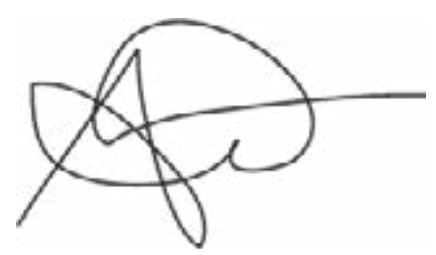

Sandra Blanche

Ltd.

N.B. \#1 L'utilisation des deux langues officielles dans ce rapport est pertinente pour exprimer les dualités aux niveau politique, culturel et social, car les choses se perdent dans la traduction.

N.B. \#2 La non-divulgation de notre organisation est intentionelle. Notre accord de confidentialité avec le gouvernement nous oblige à garder certaines informations confidentielles dans cette enquête. 


\title{
The City of Shadows - La Cité des Ombres
}

\author{
Acknowledgements
}

This investigation would have not been possible without the precious contribution of knowledgeable and experienced agents.

First and foremost, to Agent Caz, also known as Mister Yvan Cazabon, associate Professor at Carleton University. Agent Caz accepted to become my main liaison agent in this operation and without him the City of Shadows would have not seen the light. His diligent and rigorous advice on tactics on a weekly basis were accompanied with eloquent architectural concepts that I could not all quite understand at first. They were riddles for me to resolve as I was going along this experimental process. In a timely manner, as he promised, all the pieces of the puzzle finally came together. All the answers were there since the beginning, just kindly waiting for me to decode them. I feel privileged to have worked under him for this past year and am grateful for everything I learned with him.

My fellow colleague agents were also an indispensable source of motivation and inspiration for the City of Shadows case. I truly value the expertise and moral support of my team. The never-ending hours of work in room 208 and the "Queen" just brought us closer together.

I infinitely appreciate the dynamism of our entire department. It was always nice to encounter any of my coworkers in the streets of Building 22, these little things that bring light to your day and teach you to bury negative thoughts with smile and kindness.

Although I was required to comply with the confidentiality agreement of this case, I was blessed by the unconditional love and moral support of my family, partner and closest friends. Their presence made me feel that I was not alone during the darkest moments of this investigation.

My experiments in printmaking would have not been successful without the help of Agent Rob, also known as Professor Robert Hinchley from the Ottawa School of Art. He helped to refine my technique in the research of light and shadows and the excavation of materiality.

Truly and sincerely, thank you. 
$\begin{array}{ll}\text { Illustrations } & \mathrm{x} \\ \text { Preface } & 1\end{array}$
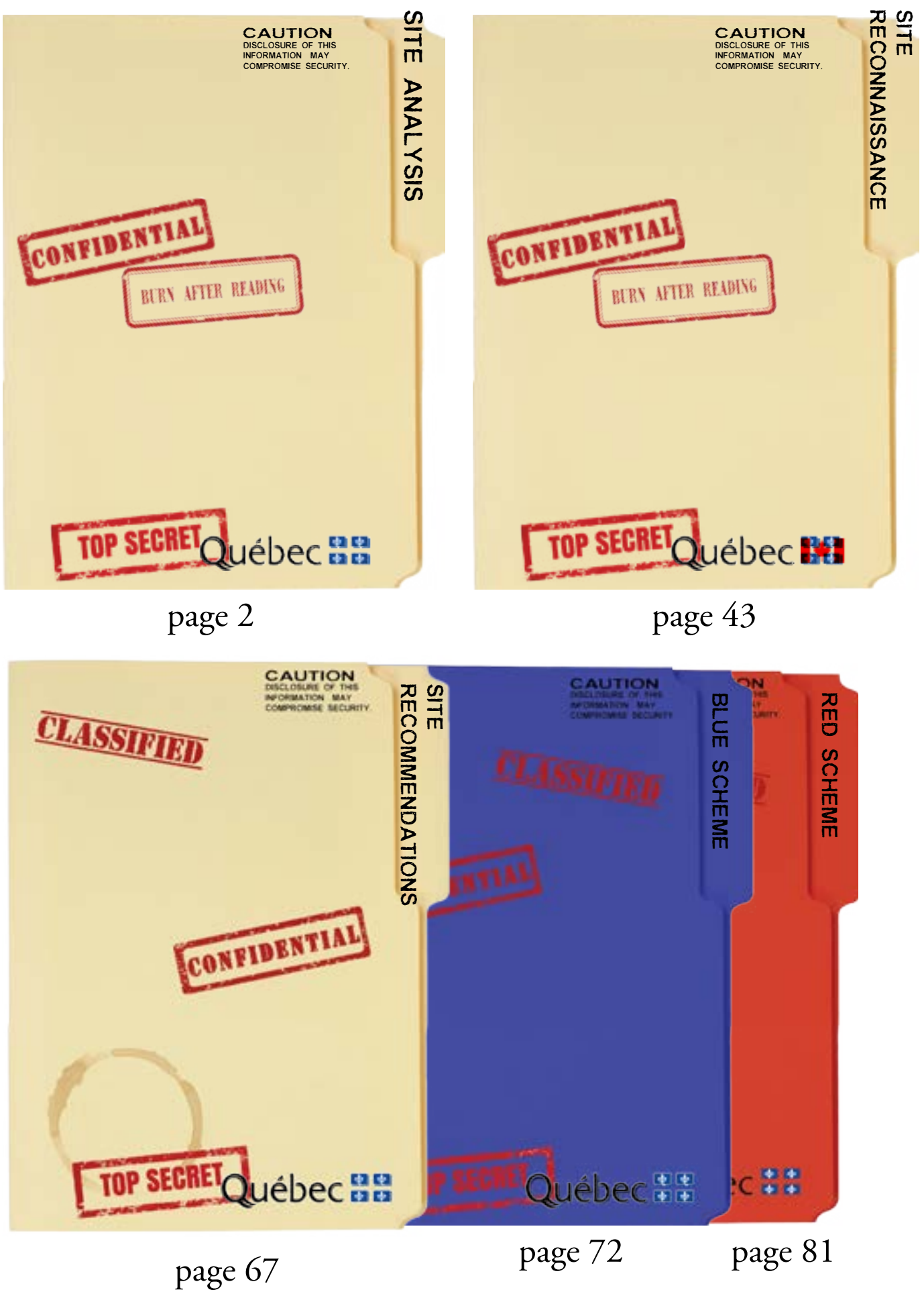

Bibliography 91

Appendices 95 


\section{The City of Shadows - La Cité des Ombres}

\section{Illustrations}

This is the list of all sketches, maps, photos and drawings by author unless otherwise noted.

\section{SITE ANALYSIS}

Illustration 1 Site map $\quad$........3

Illustration 2 a) Historic photo $\quad$........4

< http://niche-canada.org/2015/05/29/chess-2015-chaudiere-field-trip-a-primer/>

b) Historic photo <http://www.histoireforestiereoutaouais.ca/en/d3/\#10>

c) Historic photo $<$ http://niche-canada.org/2015/05/29/chess-2015-chaudiere-field-trip-a-primer/>

d) Historic photo <http://workershistorymuseum.ca/category/eb-eddy/>

e) Historic photo <idem $>$

f) Historic photo <idem>

Illustration 3 a) Historic photo

<http://outaouais.quebecheritageweb.com/article/great-hull-fire-1900>

b) Historic photo <idem>

c) Historic photo <idem>

d) Historic photo <idem>

e) Historic photo <idem>

f) Historic photo <idem>

Illustration 4 Great fire map

<http://outaouais.quebecheritageweb.com/article/great-hull-fire-1900>

Illustration 5 Collage. Historic photos

a) Historic photo <http://www.pastottawa.com/quartier/hull/>

b) Historic photo <http://niche-canada.org/2015/05/29/chess-2015-chaudiere-field-trip-a-primer/>

c) Historic photo <idem>

d) Historic photo <idem>

e) Historic photo $<$ http://outaouais.quebecheritageweb.com/article/great-hull-fire-1900>

f) Historic photo <idem>

g) Historic photo <idem>

h) Historic photo $<$ http://ottawacitizen.com/news/local-news/the-night-parliament-burned> 

i) Historic photo
<http://ottawacitizen.com/news/local-news/the-night-parliament-burned>
j) Historic photo <http://www.pastottawa.com/quartier/hull/>
k) Historic photo <idem $>$
l) Historic photo <idem $>$
m) Historic photo <idem $>$
n) Historic photo <idem $>$
o) Historic photo <idem $>$
p) Historic photo <idem $>$
q) Historic photo <idem $>$

Illustration 6 a) Historic photo <http://www.history.com/topics/prohibition>

b) Historic photo <idem $>$

c) Historic photo <idem $>$

d) Historic photo <https://www.pinterest.com/jrderocher/model-t-s/>

e) Historic photo <idem $>$

f) Historic photo <http://www.history.com/topics/prohibition>

Illustration 7 Historic photo

<http://niche-canada.org/2015/05/29/chess-2015-chaudiere-field-trip-a-primer/>

Illustration 8 Aerial map $\quad$ …...16

Illustration 9 Aerial map $\quad$.......17

Illustration 10 Aerial map $\quad$........18

Illustration 11 Aerial site picture (modified) $\quad$........19

<http://urbsite.blogspot.com/2013/12/hull-1969-1995.html>

Illustration 12 a) Historic photo <http://www.pastottawa.com/quartier/hull/>

b) Site photo <idem $>$

c) Historic photo <idem $>$

d) Site photo <idem $>$

Illustration 13 a) Historic photo <idem>

b) Site photo <idem $>$

c) Historic photo <idem $>$

d) Site photo <idem $>$

Illustration 14 a) Historic photo

<http://outaouais.quebecheritageweb.com/article/philemon-wright-1760-1839>

b) Historic photo <http://freemasonry.bcy.ca/biography/eddy_e/eddy_e.html>

c) Historic photo <http://www.canadahistory.com/sections/Politics/pm/johnmacdonald.htm>

d) Historic photo <http://www.thecanadianencyclopedia.ca/en/article/jean-lesage/>

e) Historic photo <http://www.canoe.ca/che-mun/102trudeau.html>

f) Historic photo <https://www.pinterest.com/explore/justin-trudeau-father/?lp=true> 
Illustration15 a) Newspaper cut, The Ottawa Journal

b) Newspaper cut, The Ottawa Journal

c) Newspaper cut, The Ottawa Journal

d) Newspaper cut, The Ottawa Journal

e) Newspaper cut, The Ottawa Journal

f) Newspaper cut, The Ottawa Journal

Illustration16 a) Newspaper cut, The Ottawa Journal

b) Newspaper cut, The Ottawa Journal

c) Newspaper cut, The Ottawa Journal

d) Newspaper cut, The Ottawa Journal

e) Newspaper cut, The Ottawa Journal

f) Newspaper cut, The Ottawa Journal

Illustration 17 NCC letter <http://urbsite.blogspot.com/2013/12/hull-1969-1995.html> _......27

Illustration 18 a) Newspaper cut, Ottawa Journal

b) Newspaper cut, Ottawa Journal

Illustration 19 a) NCC diagram <http://urbsite.blogspot.com/2013/12/hull-1969-1995.html>

b) NCC diagram <idem>

Illustration 20 a) NCC diagram <idem>

b) NCC diagram <idem>

Illustration 21 Idem as illustration 11

Illustration 22 a) Gaboury diagram

<http://urbsite.blogspot.com/2013/12/hull-1969-1995.html>

b) Gabroury diagram <idem>

Illustration 23 Gaboury letter <idem>

Illustration 24 Gaboury diagram <idem> $\quad$........34

Illustration 25 Gaboury diagram <idem> $\quad$........35

Illustration 26 Gaboury diagram <idem> $\quad$........36

Illustration 27 Gaboury diagram cidem> $\quad$........37

Illustration 28 Site photo <http://www.placeduportage.ca/> $\quad$........38

Illustration 29 Site photo $\quad$.........39

SITE RECONNAISSANCE

Illustration 30 Train map $\quad$........45

Illustration 31 Wood carving photo $\quad$........46

Illustration 32 Demographic map $\quad$........47

Illustration 33 Highlight map $\quad$........48

Illustration 34 a) Site photo $\quad$........49

b) Site photo

c) Site photo 

d) Site photo
e) Site photo
f) Site photo

Illustration 35 a) Site photo

b) Site photo

c) Site photo

d) Site photo

e) Site photo

Illustration 36 Study \#2 \& \#3
a) Collage 1
b) Collage 2
c) Collage 3
d) Carving photo
e) Print photo

Illustration 37 a) Collage 1

b) Collage 2

c) Collage 3

Illustration 38 Idem as Illustration 33

Illustration 39 Flipbook
a) F1 - Pictures 1 to 40
b) F2 - Pictures 41 to 81
c) F3 - Pictures 41 to 81

Illustration 40 Shadow map

Illustration 41 a) Site section

b) Zoomed in shadow map

Illustration 42 Study \#4
a) Collage-carving
b) Collage-carving
c) Collage-carving
d) Collage-carving
e) Collage-carving

Illustration 43 Study \#5

Illustration 44 Study \#6

Illustration 47 Study \#9
a) Massing model
b) Massing model
c) Massing model

Illustration 48 Precedent Studies 

a) Site photo
b) Site photo
c) Site photo (Confidential)
d) Site photo

Illustration 49 Precedent Studies
a) Site photo
b) Site photo (Confidential)
c) Site photo (Confidential)
d) Site photo (Confidential)
e) Site photo

\section{SITE RECOMMENDATIONS}

Illustration 50 Preliminary drawings
a) Perspective
b) Section drawing

Illustration 51 Preliminary Section drawing .70

Illustration 52 Preliminary Plan drawing

Thesis

Illustration 53 Plan drawing ........73

Illustration 54 Section drawing

Illustration 55 Section drawing

Illustration 56 a) Sectional model

b) Sectional model

c) Sectional model

Illustration 57 a) Vignette

b) Vignette

Illustration 58 a) Section drawing

b) Section drawing

Illustration 59 Vignette

........79

Illustration 60 Section drawing

Anti-thesis

Illustration 61 Section drawing

Illustration 62 Section drawing

Illustration 63 Plan drawing

Illustration 64 Section drawing

Illustration 65 a) Vignette

b) Vignette

Illustration 66 Vignette

........87

Illustration 67 a) Section drawing

b) Section drawing 


\title{
The City of Shadows - La Cité des Ombres
}

\author{
Preface
}

"There are two sides to every story. An inside and an outside." - Mister X

The City of Shadows is a codename. It holds the information of the medium, the key understanding of the thesis and of the anti thesis.

Printmaking employs techniques and methods that can express something more viscerally and sensorially. It is the intuitive excavation of materiality.

A carving, for the purpose of printmaking, is like an intermediate between drawing and sculpture. It produces a deeper feeling, a layering of impressions where an experience can be built. A special characteristic of printmaking is also in the printing process itself. The print is the transfer of the embossed impression of the carved surface. Depending on the material used, wood or metal, the inscription of the etching will be translated in a certain way on paper. On one hand, working with wood leaves the hand to more intuitive gestures in accordance with the fibre of the material. On the other hand, the use of metal such as zinc and steel allows for more accuracy and multiplies the possibilities for etching techniques and mixed textures of increased depth. ${ }^{1}$

The print is also shifty. It is the mirrored image inscribed on a surface by only its shadows. The carving and the print together represent the positive-negative phenomenon of an impression. Thus, printmaking is the impression left on a material by another material; a binary tension is established. Ottawa and Hull have a similar binary tension or bipolar connection. ${ }^{2}$ Ottawa, enlightened by its power has extended its reach with the development of the Portage buildings, casting their shadows across Hull.

The construction of the Portage building has asepticised the neighbourhood, depriving it from a real, continuous, and quality pedestrian experience. The proposed reconciliations set within the Portage Complex are meant to bring the inhabitants away from a governmental setup, to dwell at a different pace while allowing them to experience the spaces at a more human scale.

Printmaking plays an important role in the representational process as it intrinsically relates to the tension between the thesis and the anti thesis. The creation of new moments as such will contribute to reconnections between the people and their land, the City with its history. 


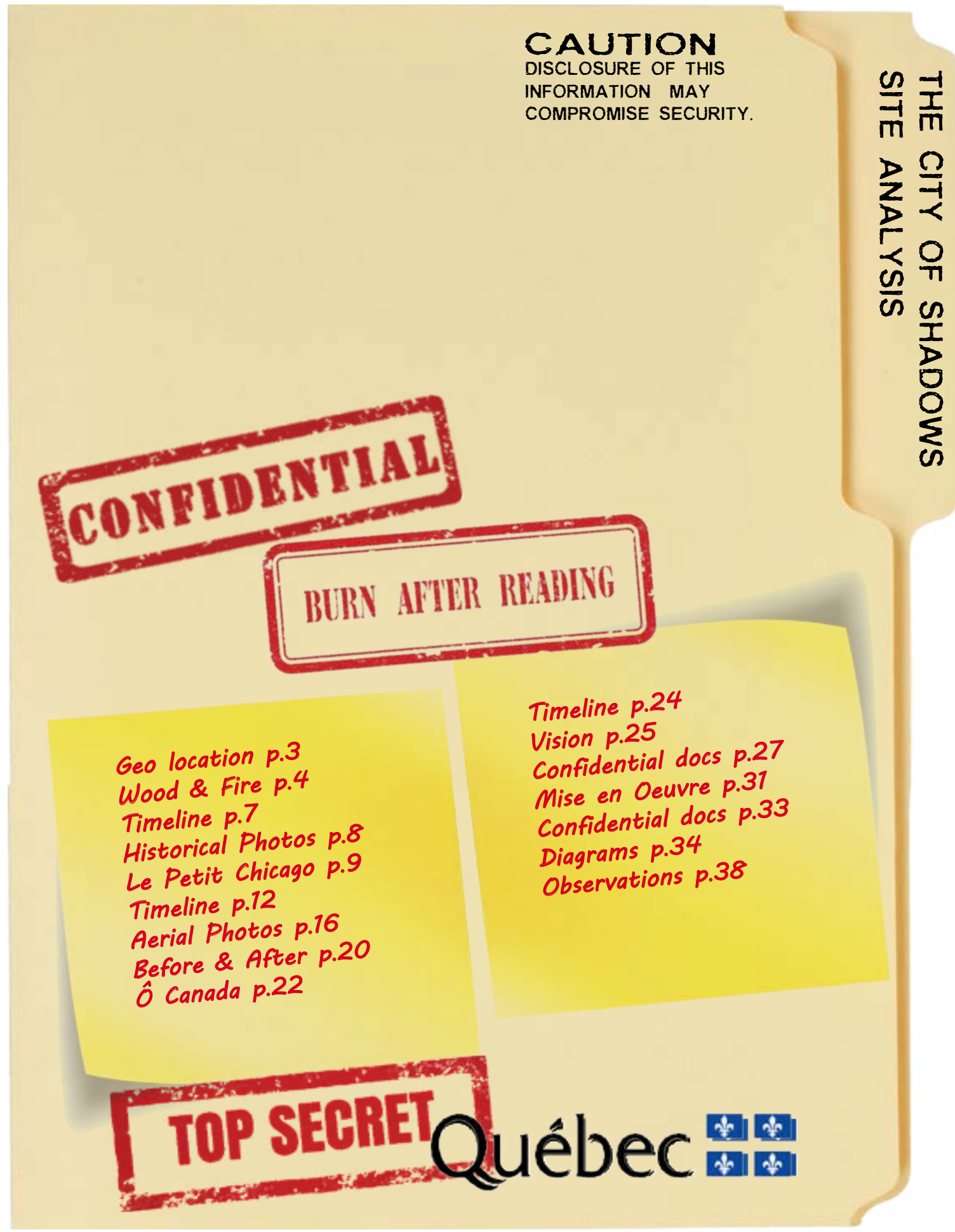




\section{AFFAIRES INTERNES \\ Québec :}

\section{GEOGRAPHICAL LOCATION}

Coordinates of the site: $45.425560,-75.714143$

Approximate population of Hull: 69,004

$80 \%$ French as first language $9 \%$ English as first language ${ }^{3}$

Hull is geographically considered an Island

Illustration 1 Site map

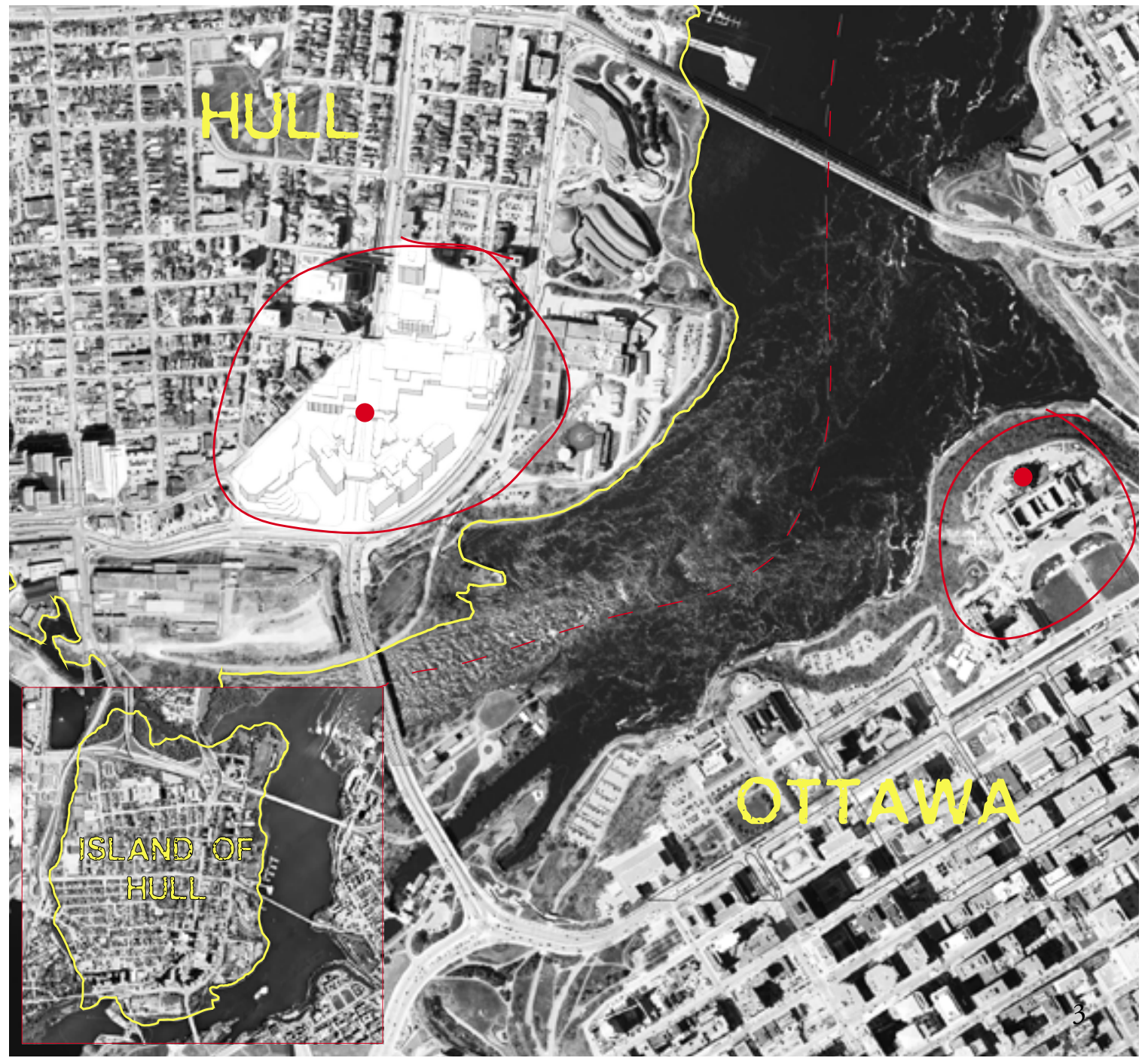




\section{AFFAIRES INTERNES \\ Québec 疃}

\section{HULL \\ HISTORY}

\section{Wood \& Fire}
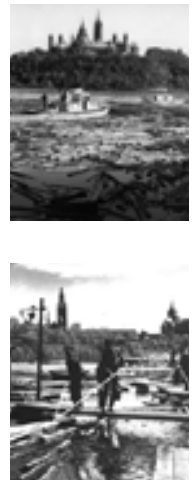

Hull is the oldest district in the city of Gatineau, located north of the Ottawa River shore. Founded in 1800 by Philemon Wright, the city was originally called "Wright's Town". ${ }^{4}$ Hull is first known as a worker area. A majority of Hull's inhabitants are employed by the EB Eddy factories and the city's Lumber companies. All aggregated by the water, the industries are overlooked by the Parliament in Ottawa (formerly known as Bytowne ).

Le coeur de la création de Hull est fondé sur l'industrialisation du bois d'ceuvre, du papier et des allumettes qui a d'ailleurs monopolisé la rive québécoise sur plusieurs décennies. Le caractère industriel fait entièrement partie de l'identité hulloise. Plusieurs de ses vestiges occupent toujours la bordure de l'eau. Le métier de draveur dans la Rivière des Outaouais, principalement à Hull, a connu sa popularité dû au nombre son extinction d'ici 1990.
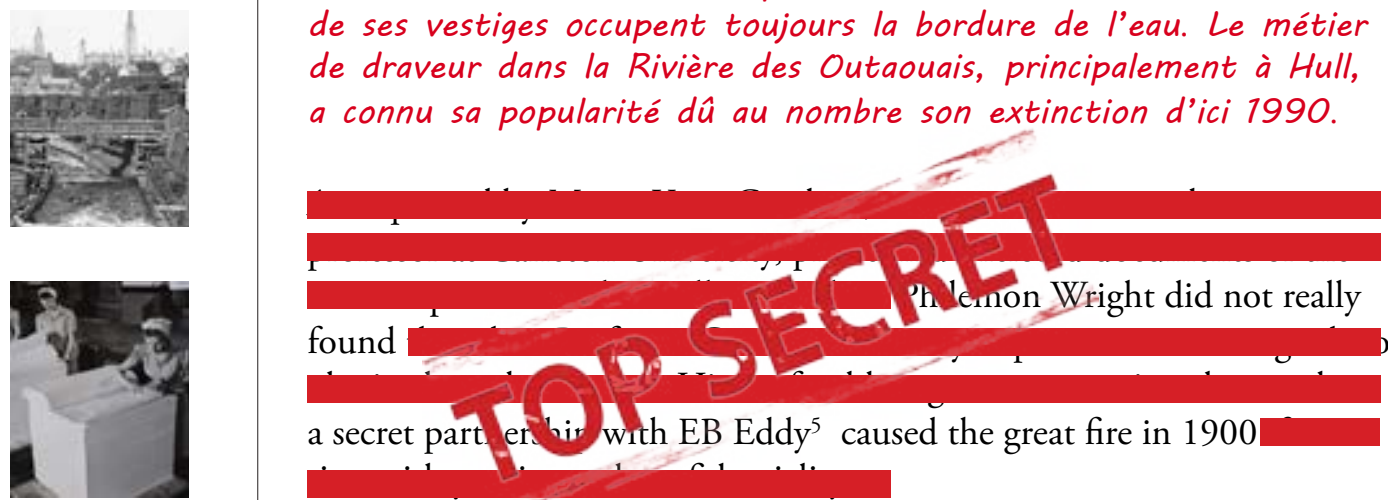

a secret part fer with EB Eddy ${ }^{5}$ caused the great fire in 1900

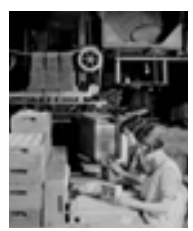

Suite à l'incendie du Parlement à Montréal en 1849, Ottawa est reconnue pour sa localisation géographique. Apparemment plus sure pour recevoir le Parlement et éviter toute attaque surprise de la part de l'ennemi. Hull et Ottawa sont reconnues comme étant la région de la Capitale Nationale en 1850. ${ }^{6}$ Un grand feu a causé la reconstruction de Hull et Ottawa en 1900.

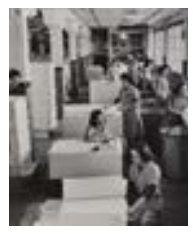

With the high demand for workforce, the area was populated and built very quickly. The dwellings, also called match houses, are flimsy and made of low cost materials. These same buildings are at the origin of multiple fires occurring between 1870 and $1971 .^{78}$ 


\section{AFFAIRES INTERNES \\ Québec}

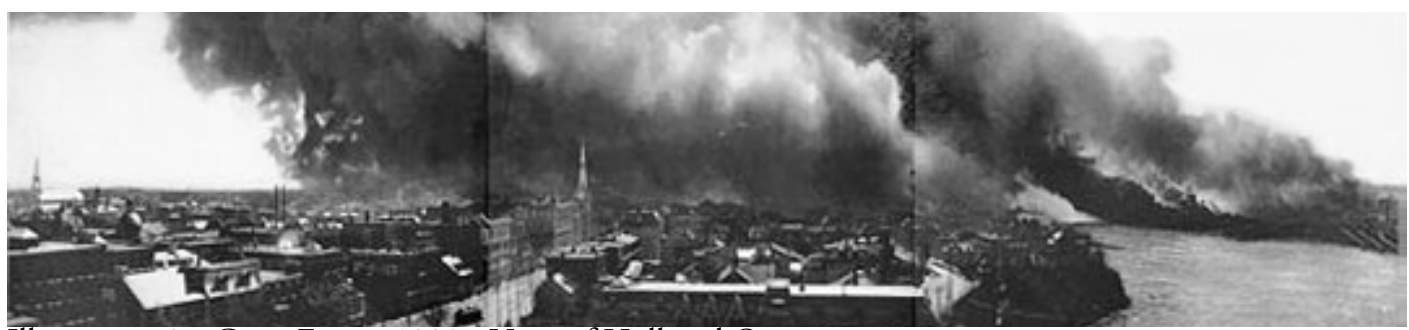

Illustration 3a Great Fire in 1990 - View of Hull and Otrawa
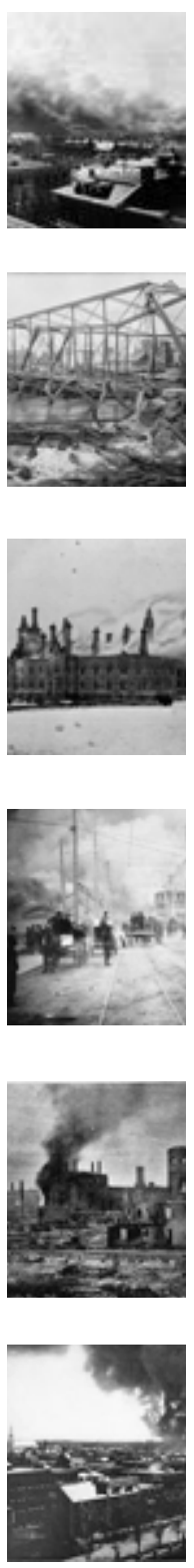

The very inflammable substances from the factories acted as an amplifier for the Great Fire of April 26th, 1900. In a matter of a couple of hours, the fire has traveled South from Vaudreuil and St Redempteur street by the shore where Eddy Mills and Hull Lumber Company have been destroyed. ${ }^{9}$

The Laurier's family was involved in several

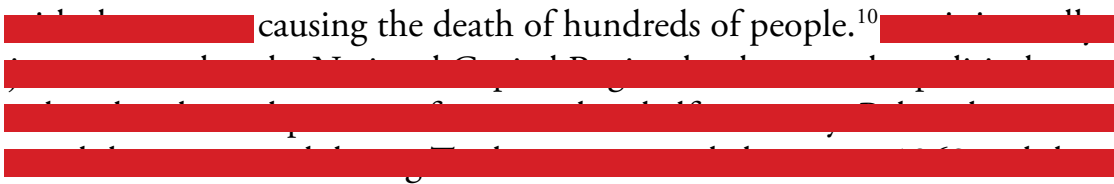

${ }^{11}$ Over 3,200 buildings were destroyed; 1,300 in Hull and 1,900 in Ottawa. The event leaves 5,789 people without a place to live and to work.

The damages in Hull for this period is estimated at $\$ 3,300,494$ of which only $25 \%$ has been covered by insurance. In 2017-dollar value, the damages are estimated at $\$ 89,283,317 . .^{12}$

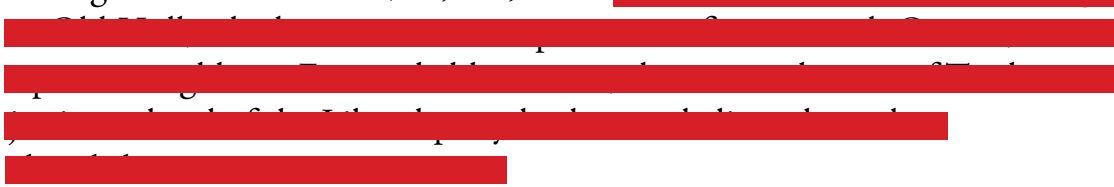

"Besides monetary assistance $(\$ 956,962.77)$, great quantities of food and clothing were sent in from all over Canada and transported free of charge by the railroads. " 13

The Great fire damaged 276 acres in Hull and 440 acres in Ottawa; millions of board feet of lumber were burned. ${ }^{14}$ 
AFFAIRES INTERNES

Québec 봄

\section{HULL}

\section{TIMELINE}

Industrial/Fire

Chaudière Bridge Construction 1828

(Union Bridge)

E.B. Eddy Company was created 1854

Alexandra Bridge Construction

Hull-Ottawa Great fire 1900

Parlement incendié 1916

Canadian International Paper mill 1926

Chaudière dam Construction

Museum of Canadian History 1989

built on lumber company site

Attached documents:

Great fire map, fire pictures

\section{Socio-Cultural}

1800 Hull founded by Philemon Wright

1850 Ottawa named

National Capital

1917 Night life (2000)

1918 Prohibition on the sale

of alcohol in Hull (1920)

Contrebande

1985 Hull criminalité $7^{\text {er }}$ au Québec

2000 Hull criminality rate $-75 \%$

2002 Merging Hull and Gatineau

2004 Hull's bar closing hours set at 2 a.m. 


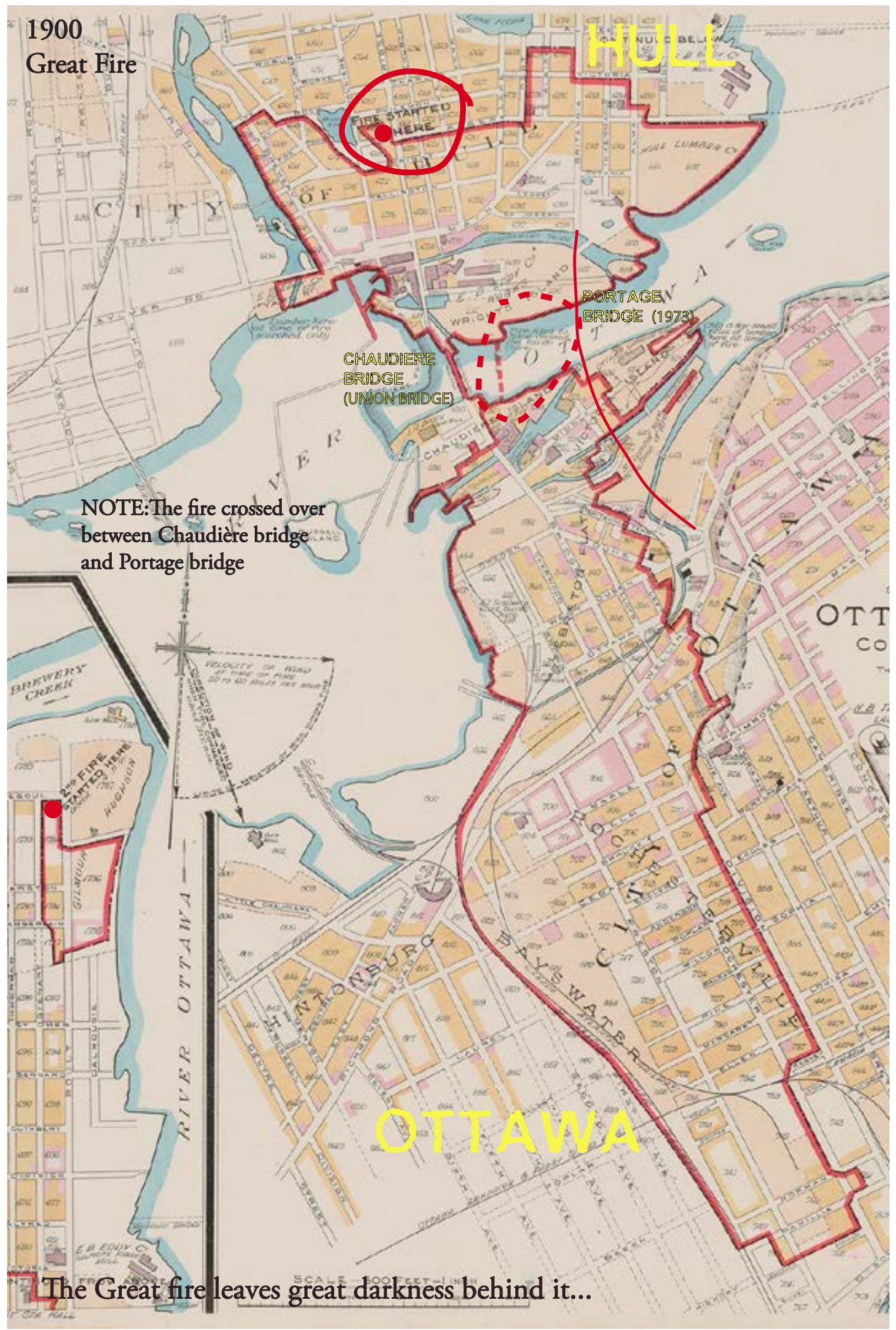




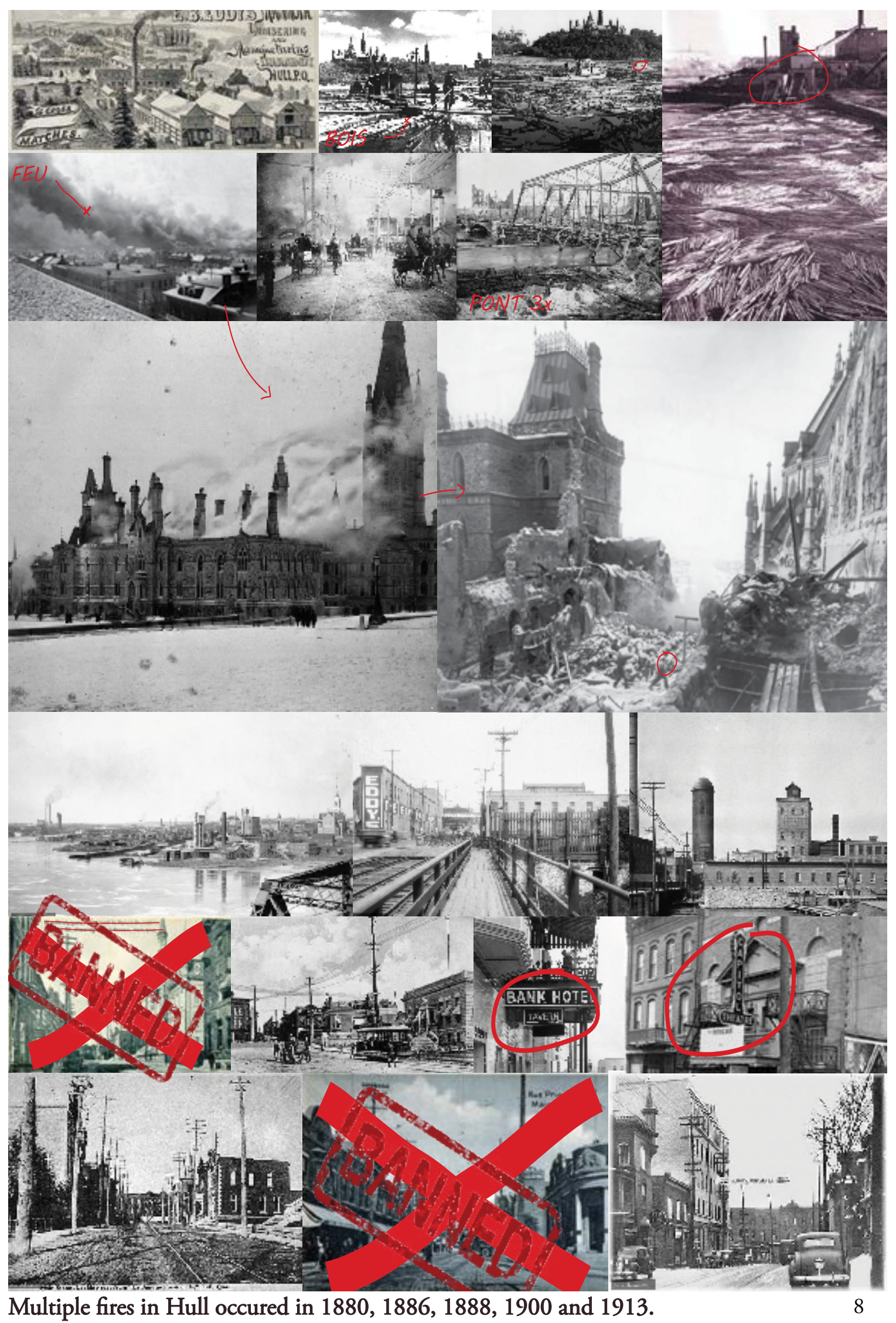




\section{AFFAIRES INTERNES \\ Québec}

\section{HULL \\ HISTORY}

Molotov cocktail at

Le Petit Chicago

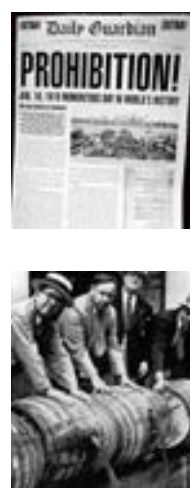

Prohibition of alcohol in Canada occurred in various stages. The country nationally banned the sale of alcohol from 1918 to 1920 . A few provinces repealed the ban only in the late 1920's which allowed a fruitful trade with the US, obliged to the Eighteenth Amendment of the Constitution from 1920 to $1933 . .^{15}$ One of the most renowned crime organizer, Al Capone, succeeded to the bootlegging business in Chicago; bringing fine products to Canadian drinkers.

Al Capone was frequently found in Hull, enjoying the pleasure of gambling houses, taverns and women. It is under these circumstances that Hull found the name of "Le Petit Chicago". ${ }^{16}$
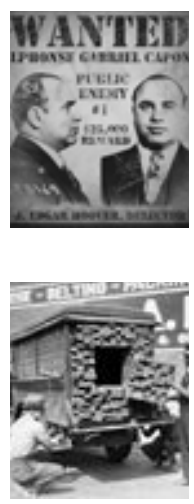

Although prohibition is affecting albeit differently both provinces of Quebec and Ontario but differently; Hull lives under prohibition from May 1918 to July 1919 while Ottawa endures it from 1916-46. Although "prohibition overlapped in both provinces for a period of about fourteen months, the flow of Ontario-to-Quebec drinkers did not wane." ${ }^{17}$ Clandestine bars and bootlegging activities are taking root in Old Hull. Production of illegal moonshine and underground bars are not stopped by public morality movements. ${ }^{18}$

La relation incestueuse entre Hull et Ottawa est à l'origine de ses sombres moeurs. Hull grandit tel un rhizome, dans l'ombre et sous terre tandis que la grande soeur. Ottawa, s'élève de toute sa grandeur en prônant la paix en haut de sa tour. La ville de la capitale nationale resserre les écluses de la moralité chez ses gens et se débâcle avec effervescence dans chaque taverne, bar et maison de jeu, en aval, de l'autre côté de la rive.

Many Ontarians head to Hull to drink and it results of numerous arrests for alcohol-related offences. Between 1920 and 1930, 75\% of the people arrested in Hull were from out of province. ${ }^{19}$ Although the number of arrests declined after 1946, Hull remains a center of attraction for its night life. 


\section{AFFAIRES INTERNES \\ Québec}

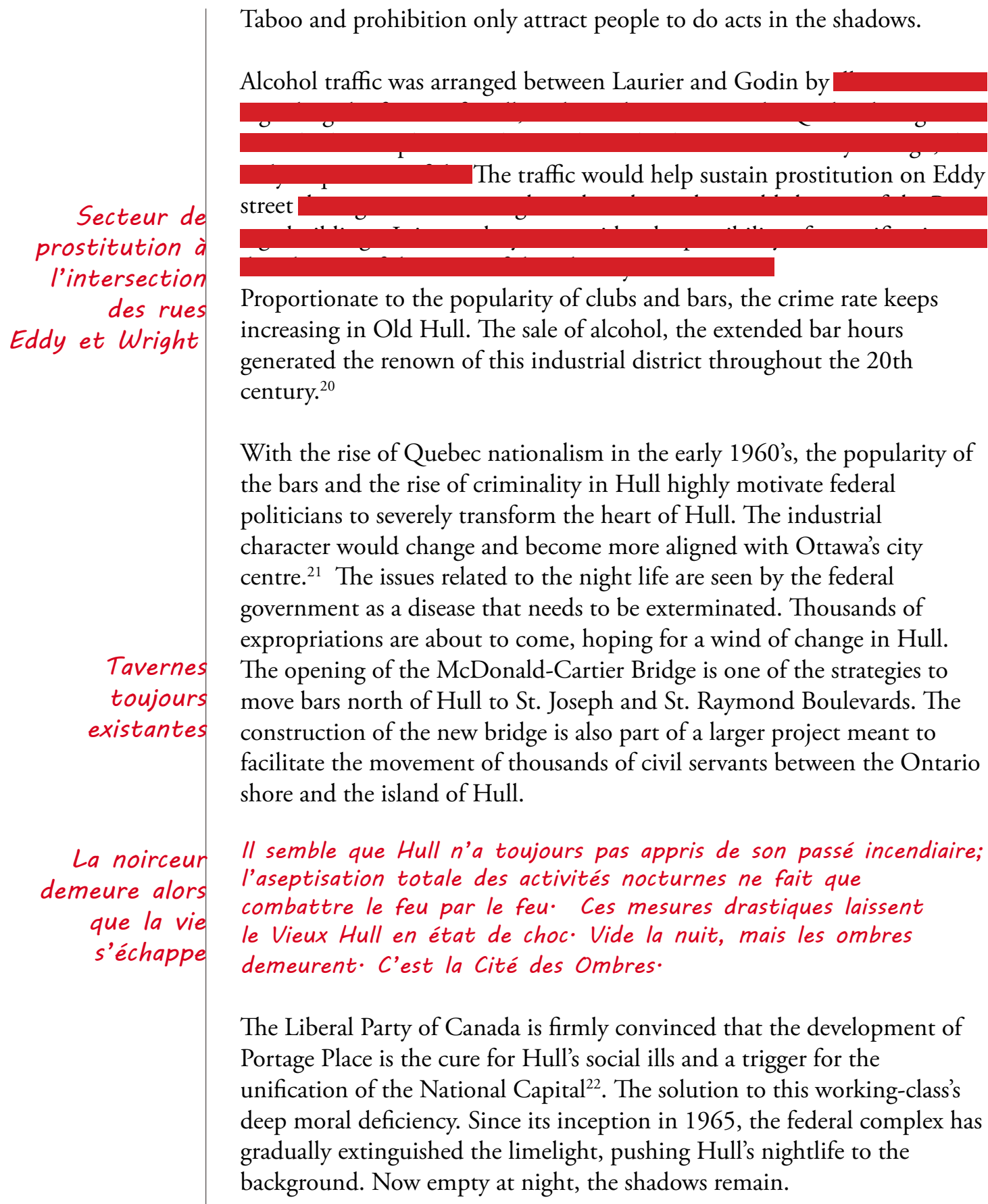

The Liberal Party of Canada is firmly convinced that the development of Portage Place is the cure for Hull's social ills and a trigger for the unification of the National Capital ${ }^{22}$. The solution to this working-class's deep moral deficiency. Since its inception in 1965, the federal complex has gradually extinguished the limelight, pushing Hull's nightlife to the background. Now empty at night, the shadows remain. 


\section{AFFAIRES BILINGUES INTERPROVINCIALES \\ Québec}

This is the City of Shadows. 
HULL

\section{MAIN TIMELINE}

Industrial/Fire

Socio-Cultural

Political

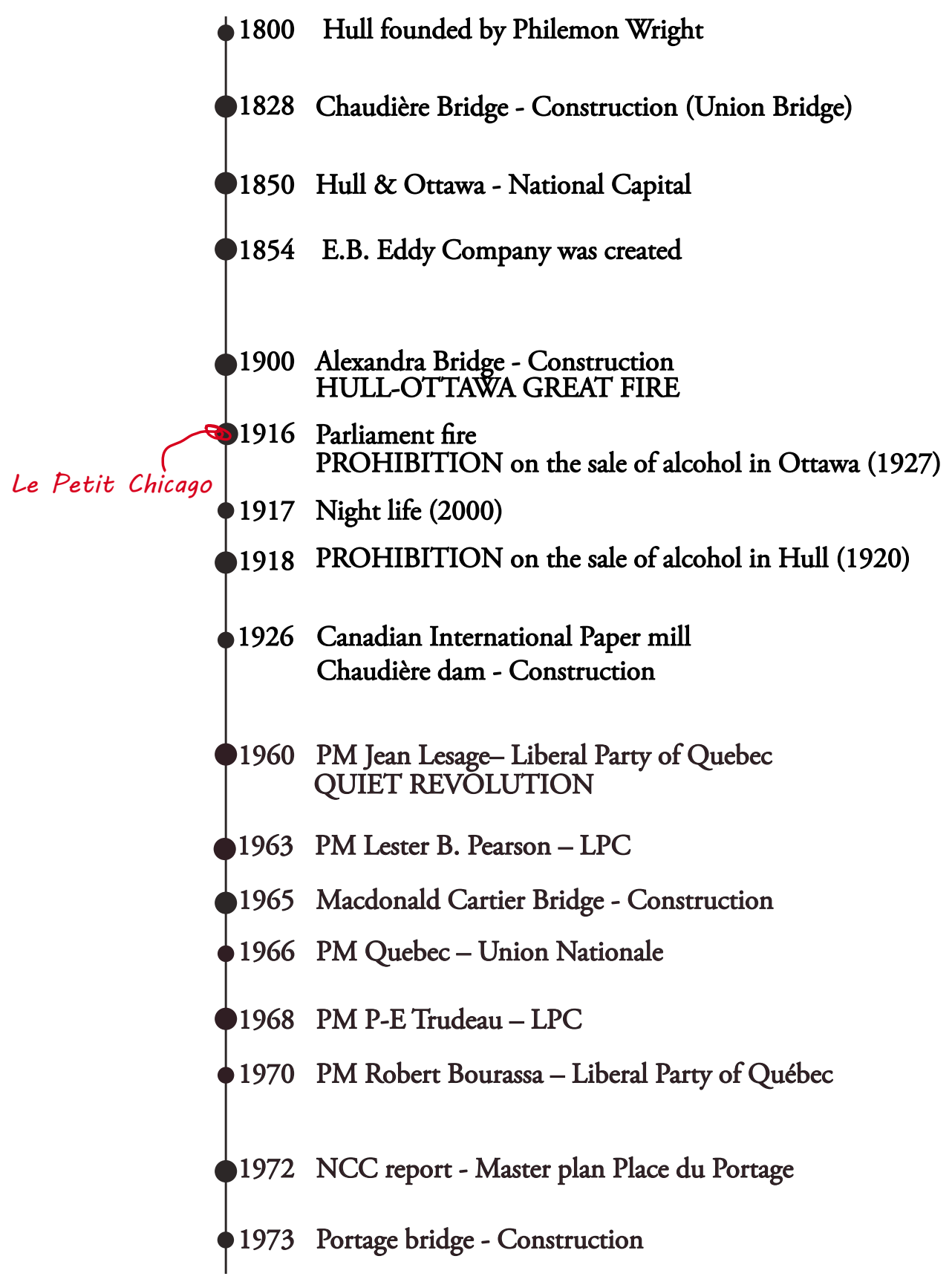




\section{AFFAIRES BILINGUES INTERPROVINCIALES \\ Québec}

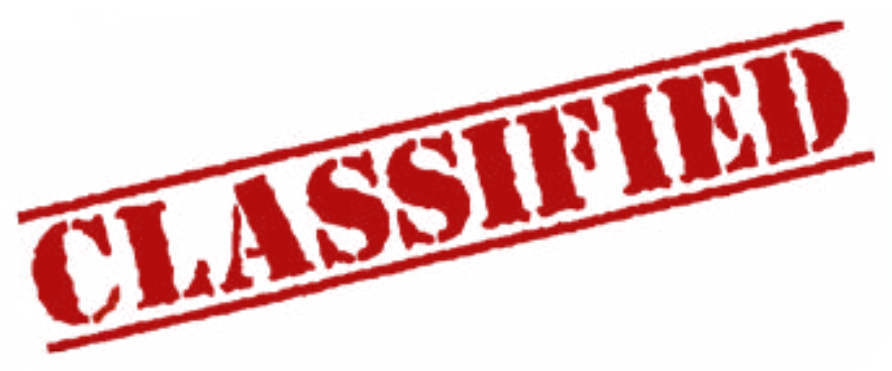

The following evidence contributes to the understanding the evolution of the implementation of the Portage Buildings Phases I-I-III-VI. 


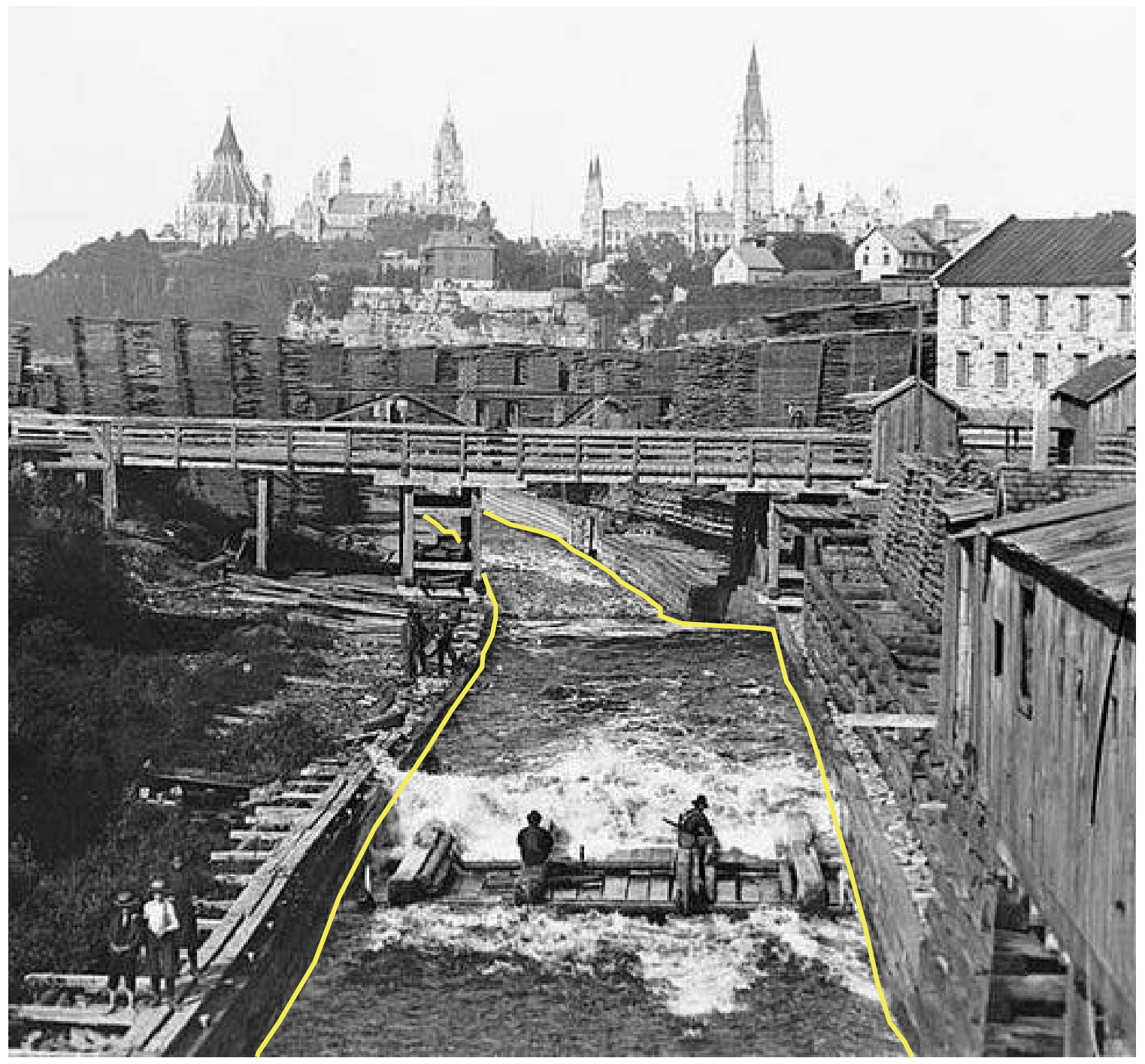

Illustration 7 Timber slide in Hull 


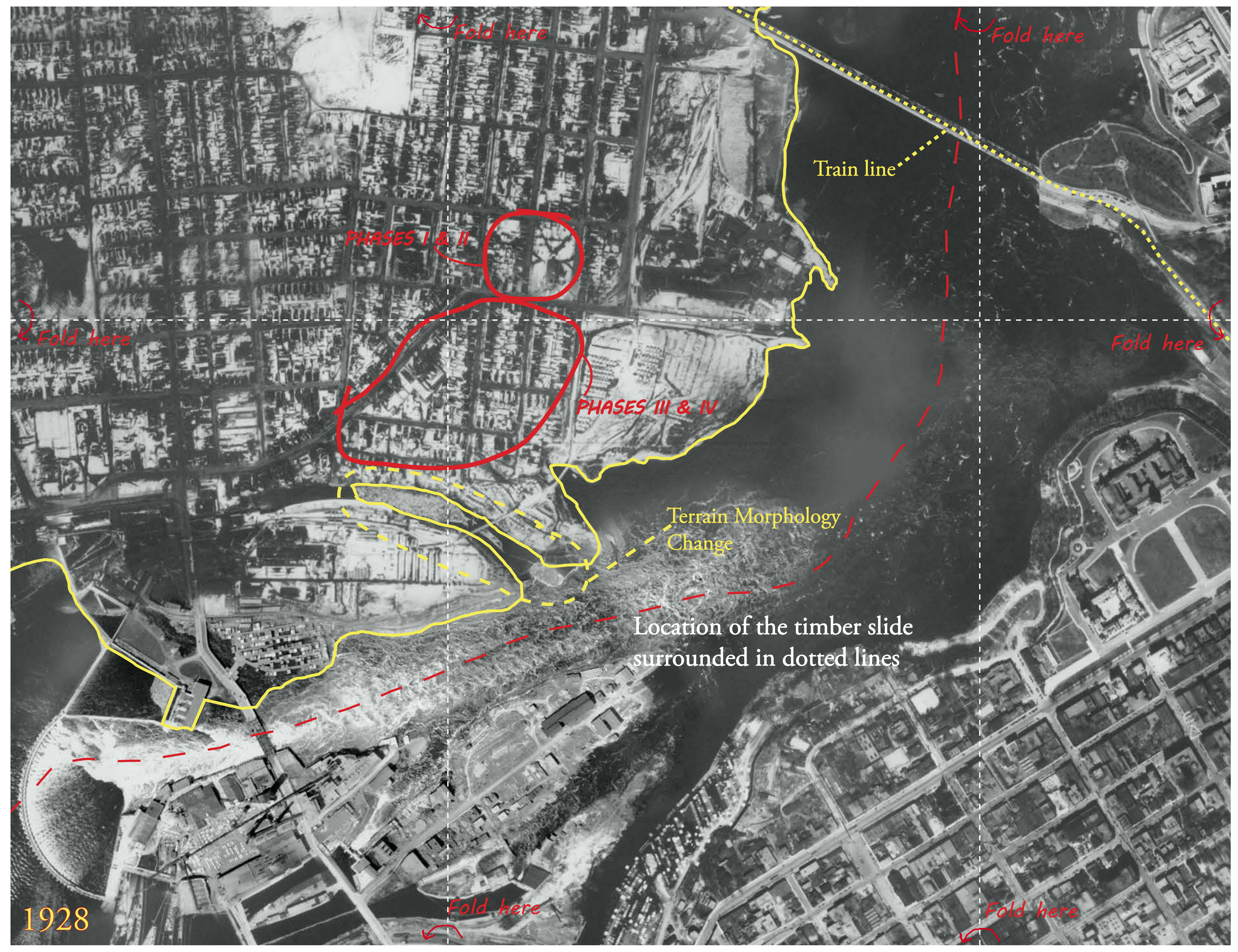




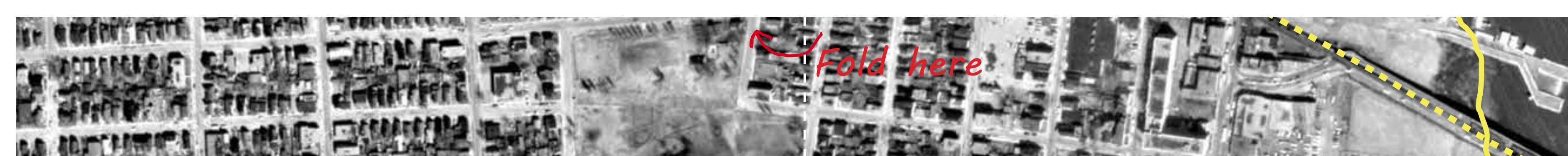

Yow

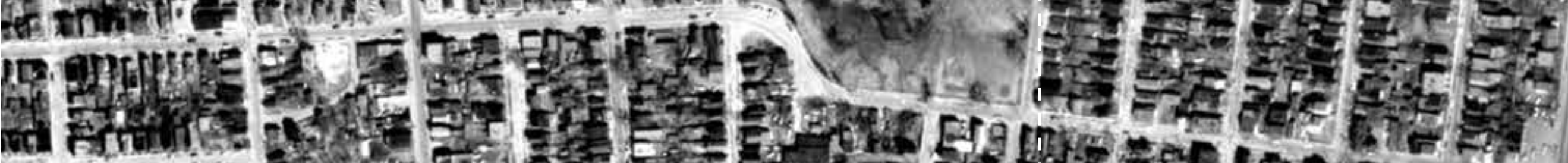

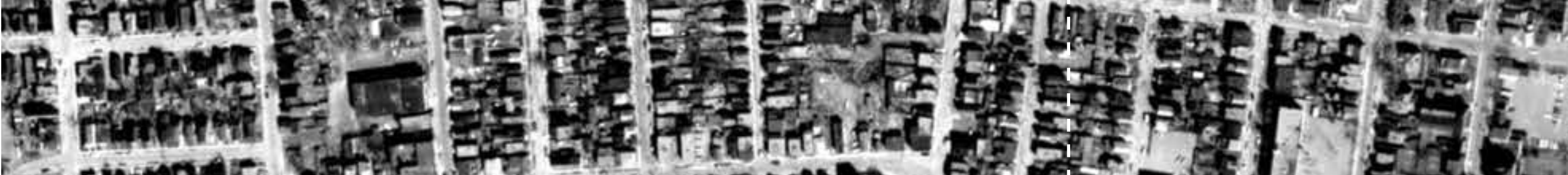

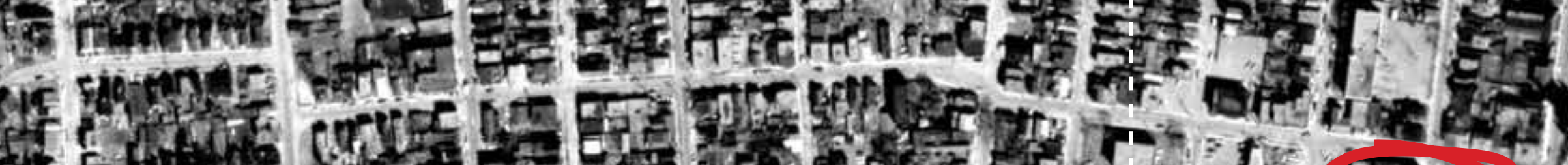

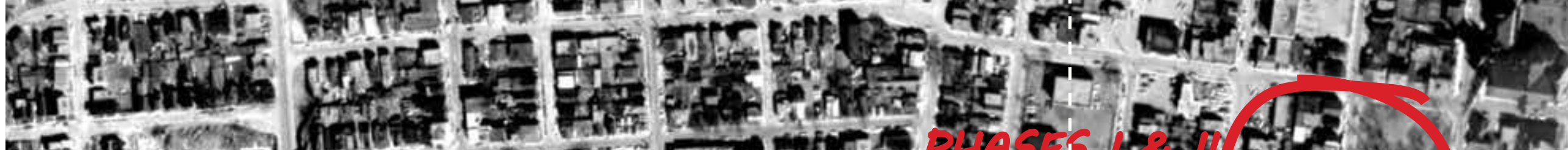

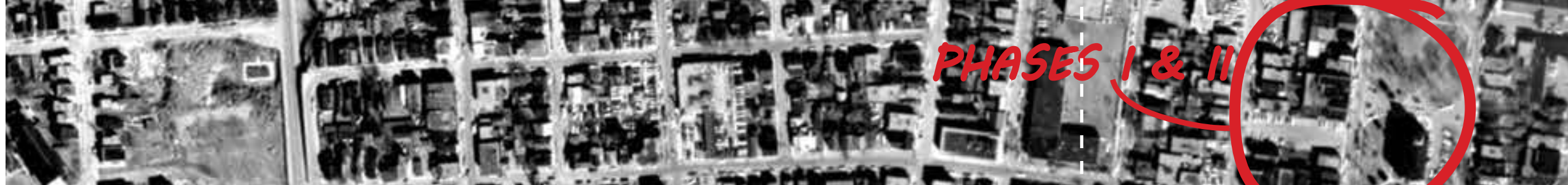

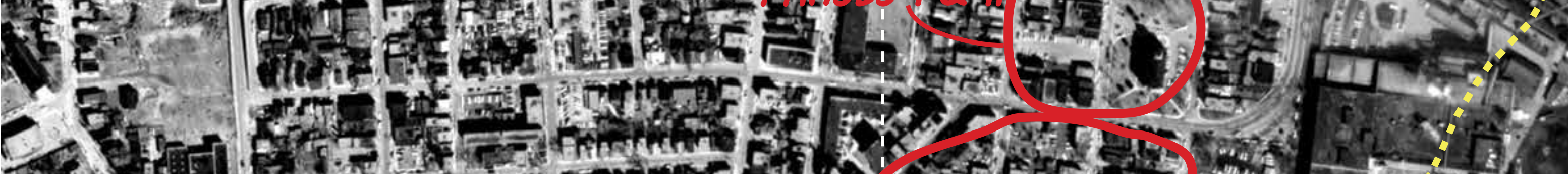
Thumb to

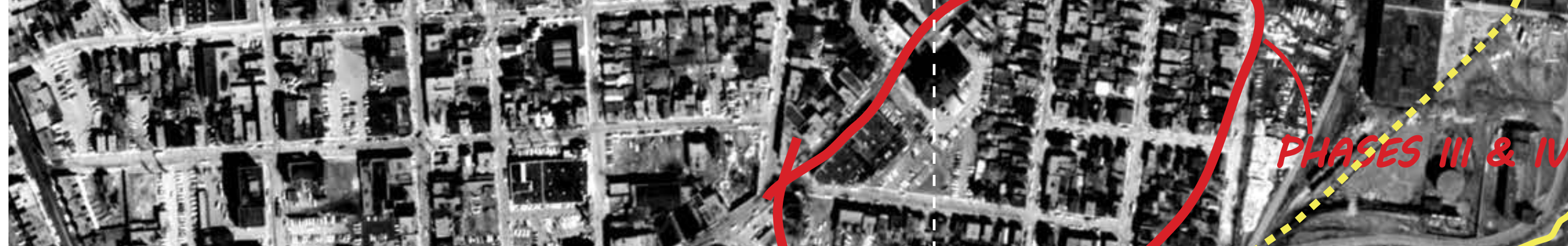

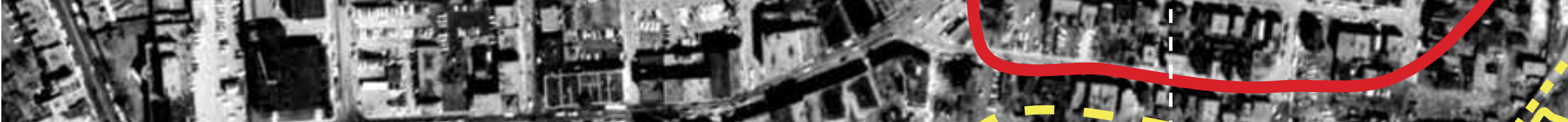

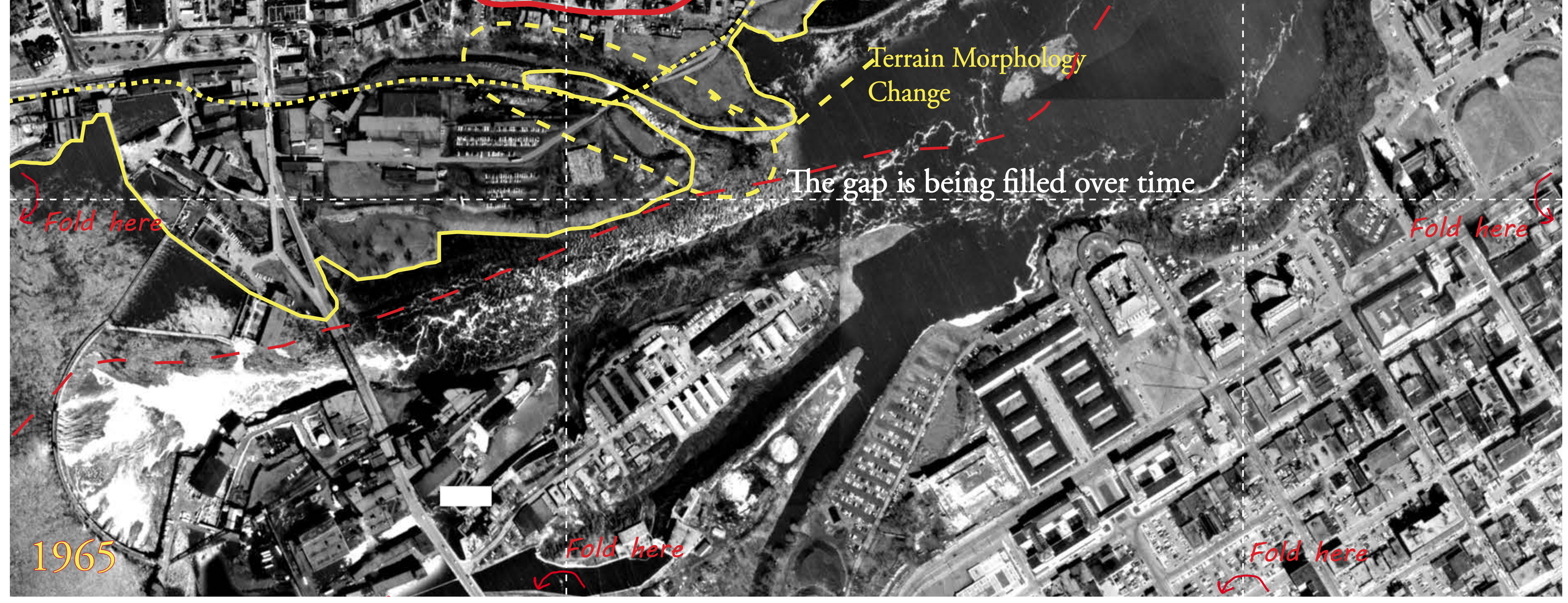




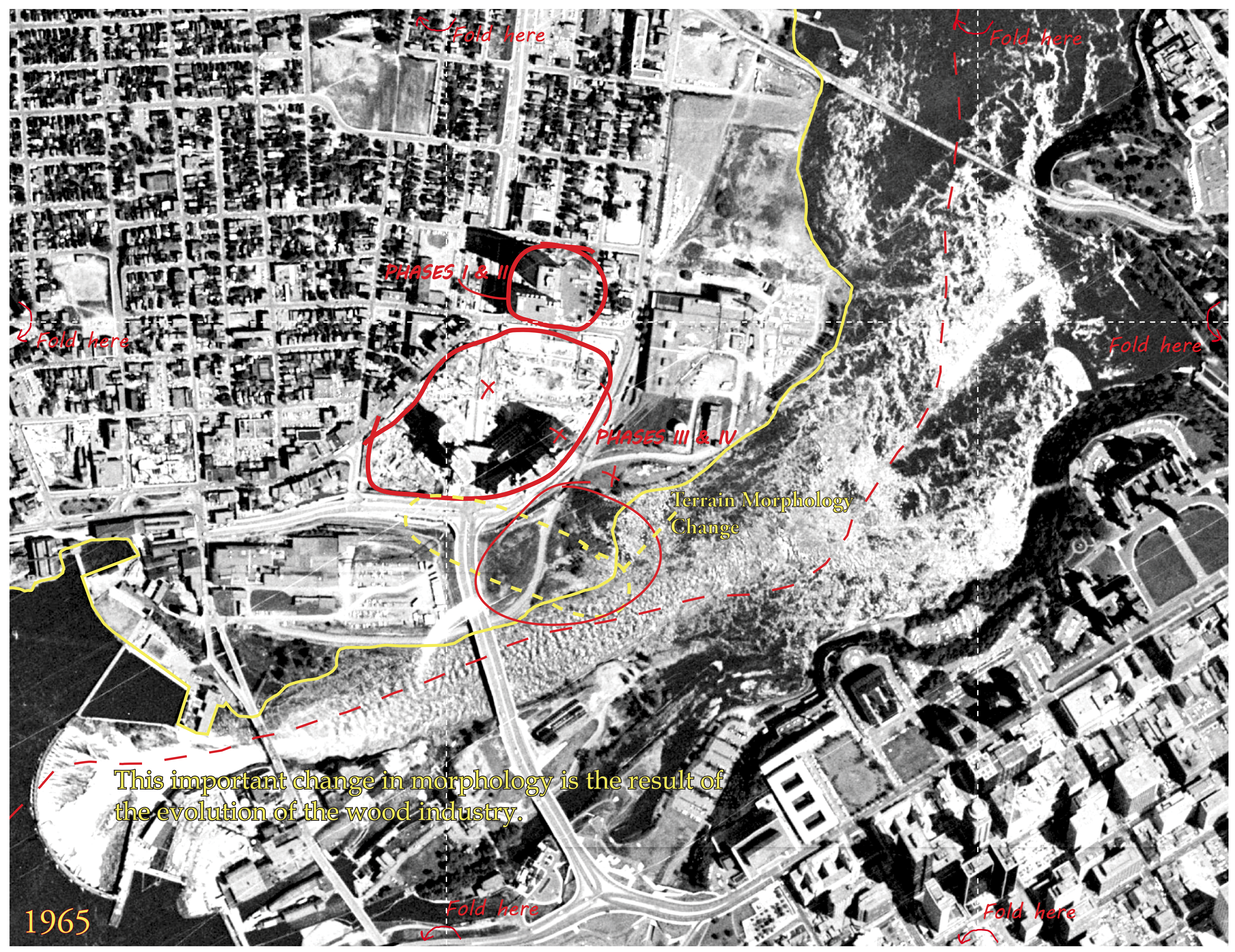




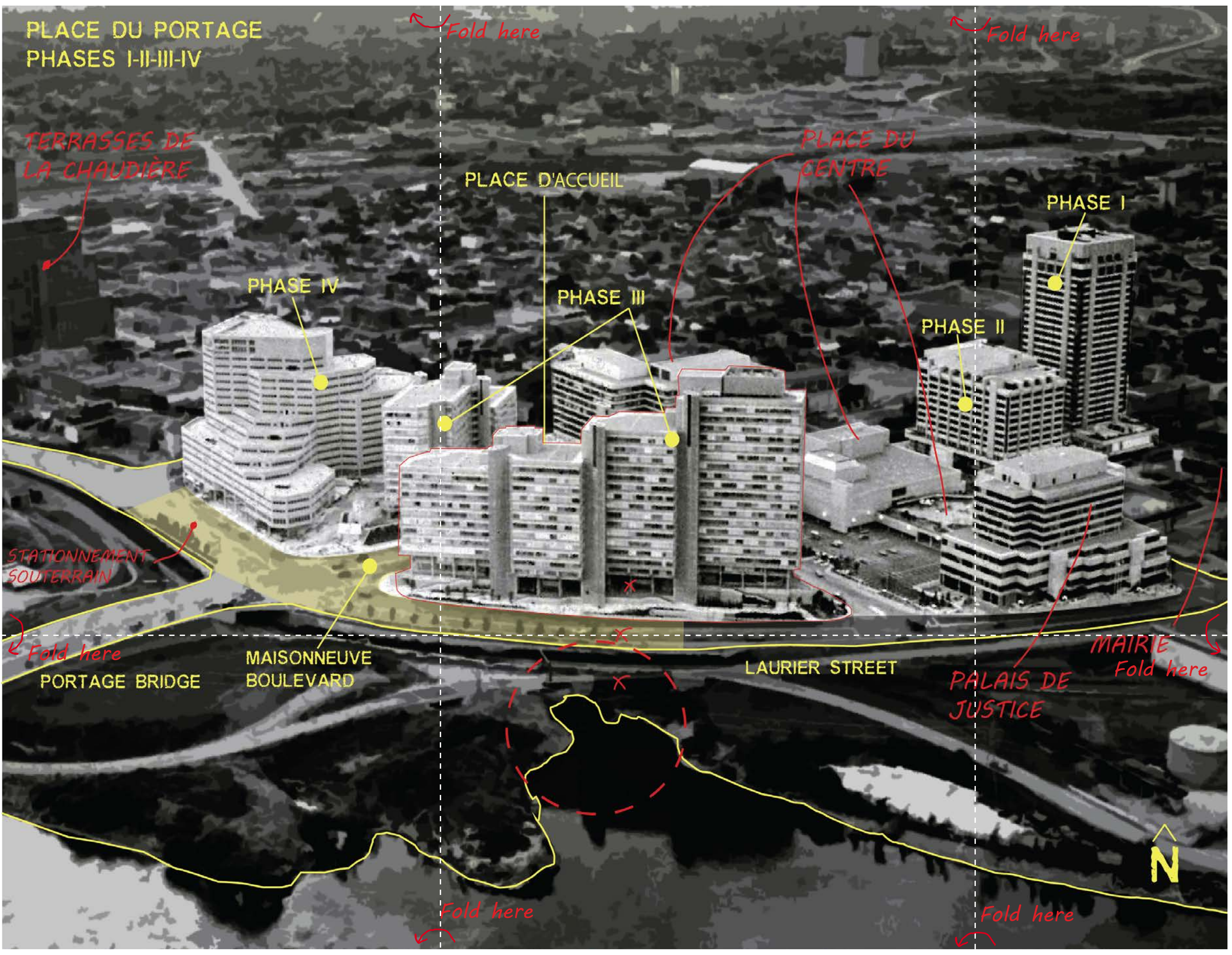




\title{
AFFAIRES BILINGUES INTERPROVINCIALES \\ Québec
}

\author{
BEFORE \& AFTER
}

The aerial photographs clearly show the varying delineations of the shore between 1928 and today. The match, wood and paper industries have greatly affected the morphology of the terrain. The railroad system originally connecting Hull and Ottawa saw drastic changes on the Hull side with its replacement by bike paths and the creation of new main roads.

Illustrations $12 \mathrm{a}, \mathrm{b}$ View of Hull from Ottawa

Few industrial vestiges remain

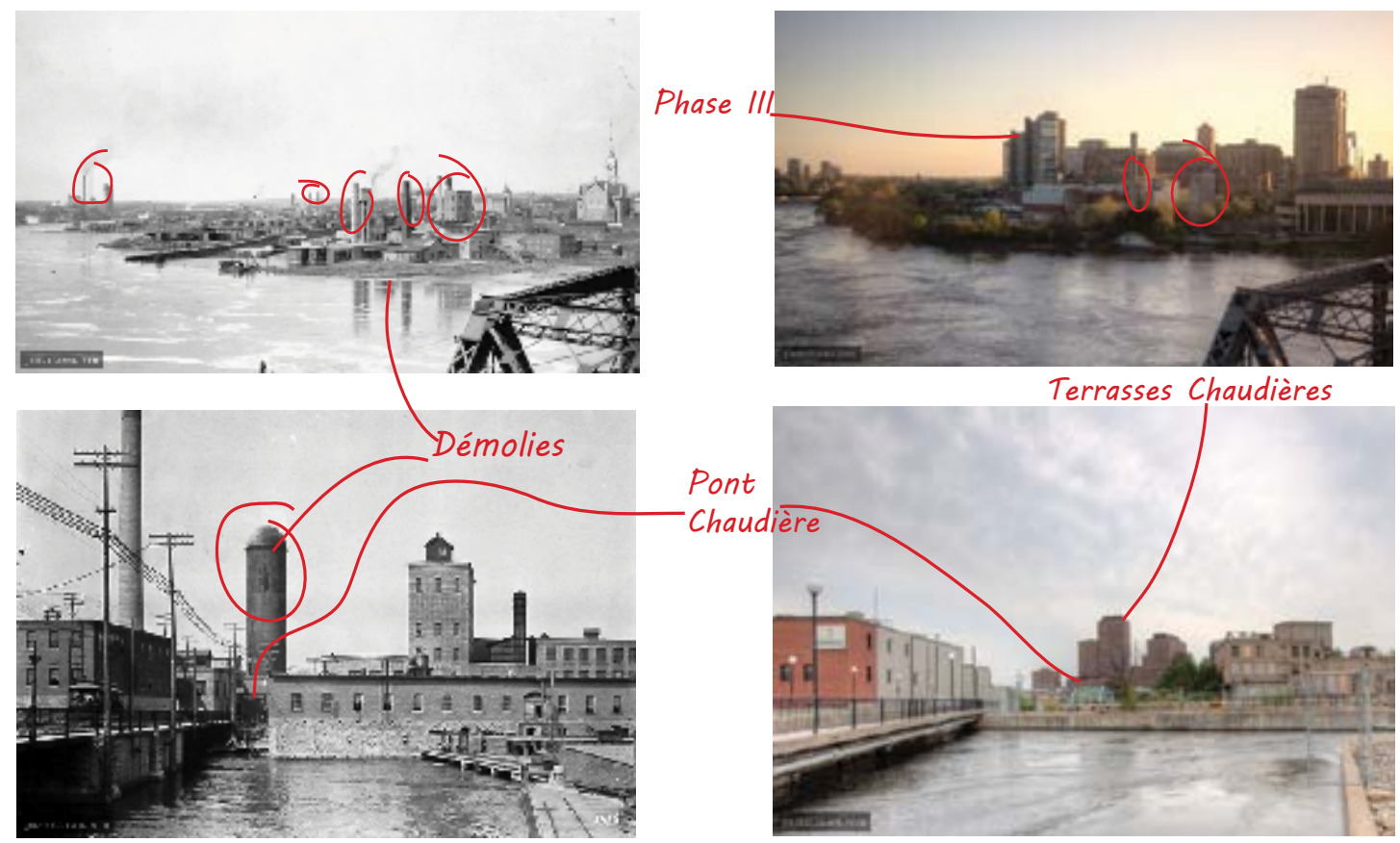

Ilustrations $12 \mathrm{c}, \mathrm{d}$ View of Hull from Booth Street

(Chaudière bridge) 


\section{AFFAIRES BILINGUES INTERPROVINCIALES \\ Québec 毘}

\section{BEFORE \& AFTER}

Malgré la démolition et l'éradication d'emblèmes industriels historiques au niveau de la surface, les ancrages demeurent... Bien que seulement 48 ans ont passé depuis l'établissement des bâtisses Portage, l'allure topographique est méconnaissable. (Voir photos aériennes)

With the examination of the historical pictures of the wood industries, the opening in the terrain identified on the maps signify a timber slide at the river's shore. That opening and timber slide are filled over time.

$\underline{\text { Illustrations } 13 \mathrm{a}, \mathrm{b}}$ View \#1 Promenade du Portage (Main street)
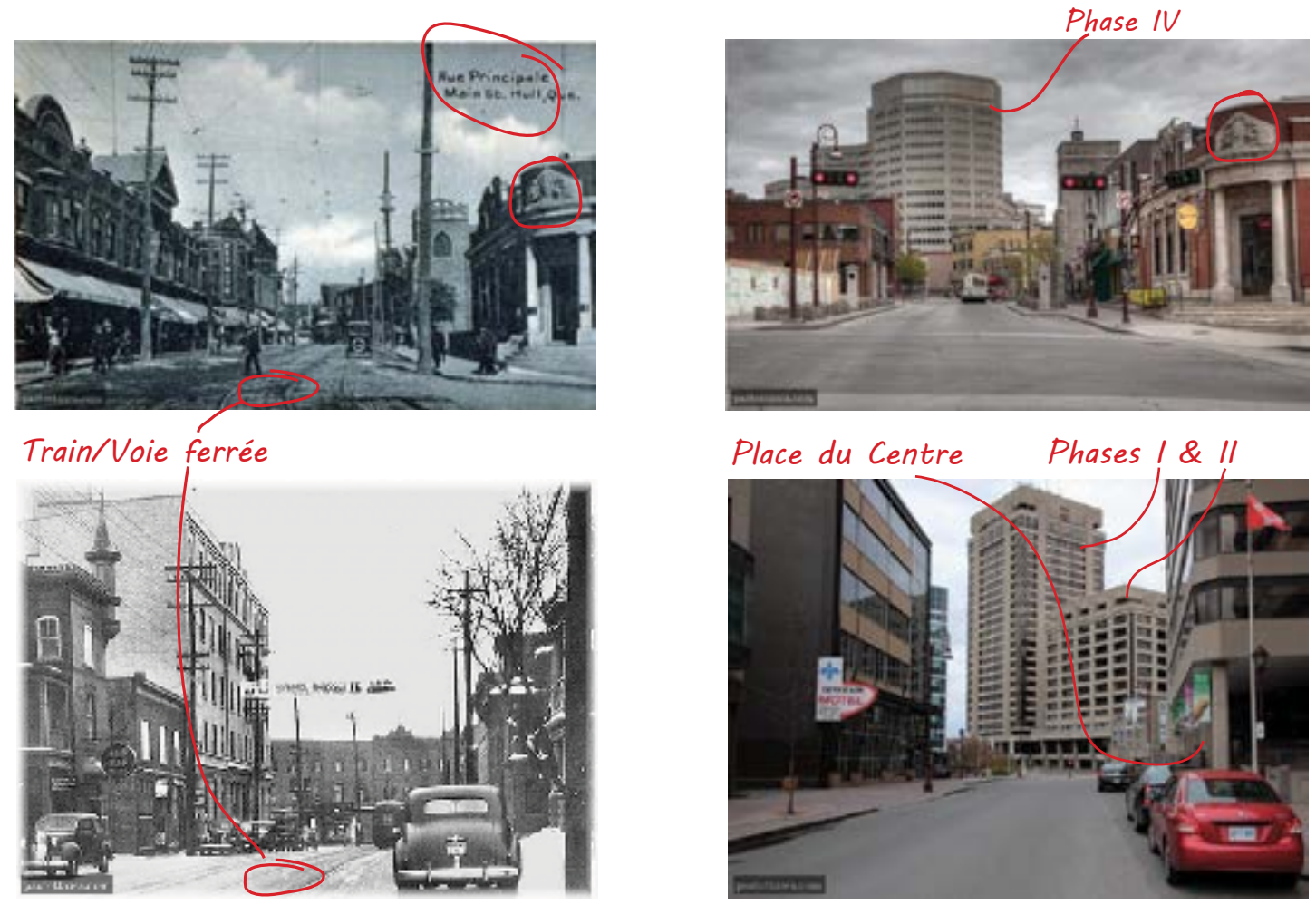

\section{Illustrations $13 \mathrm{cdd}$ View \#2 Promenade du Portage ( Main street)}




\section{AFFAIRES INTERNES \\ Québec 疃}

\section{HULL \\ HISTORY \\ Ô Canada}

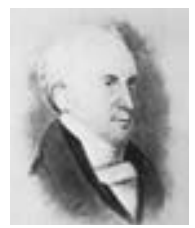

La Révolution tranquille consiste en une réorientation de l'État québécois qui adopte les principes de l'État-providence. Une séparation entre l'Église catholique et l'État, et la construction d'une nouvelle identité nationale québécoise s'éloignent du nationalisme traditionnel canadien-français. ${ }^{23}$
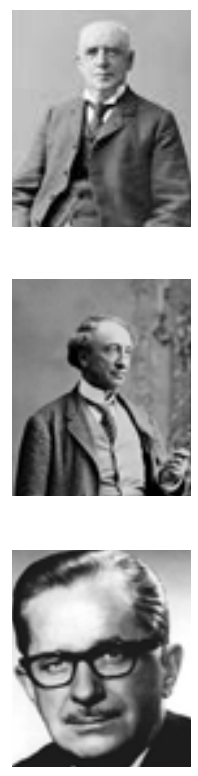

The Quiet Revolution is an important break in the history of Quebec. It is the continuation of an evolution that began in the nineteenth century by the advent of industrialization and urbanization. The Revolution begins after the death of Quebec's Prime Minister Maurice Duplessis of the National Union in 1959. The next provincial election of 1960 brings to power Jean Lesage of the Liberal Party. The Quiet Revolution spans from 1960 for almost two decades. During this short period of history, Quebec defines a new identity detached from religious beliefs. ${ }^{24}$

Depuis la dissolution de l'Union Nationale en 1970, une tension politique se continue entre les partis Libéral et Québécois sur plusieurs décennies. La croissance de l'appareil gouvernemental provincial interventionniste frictionne avec la philosophie centralisatrice du gouvernement fédéral.

Lester B. Pearson leader of the Liberal party of Canada starts his mandate as the Prime Minister of Canada in 1963. Pierre Elliott Trudeau takes over the mandate for the same party in 1968 until 1979.

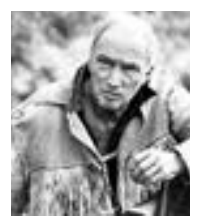

English-Canada is concerned about the changes taking place within Quebec society and the demands of its population. In 1963, Prime Minister Lester B. Pearson asks the question: "What does Quebec want?"

"Que faire pour assimiler le Québec?"

Canada institutes the Royal Commission on Bilingualism and

Biculturalism in an attempt to answer the question to satisfy the demands of Quebecers. However, the implementation of the proposed measures only increases the division between English-speaking Canadians and Francophone Quebecers. ${ }^{25}$ 


\section{AFFAIRES INTERNES \\ Québec}

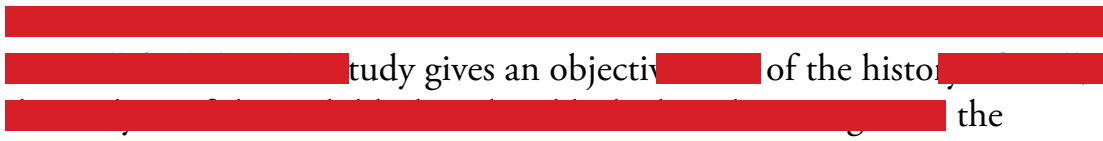

observations of the analysis and the resulting recommendations.

land expropriations.

Les Canadiens-anglais considèrent que les mesures mises en place par le gouvernement fédéral sont des concessions inacceptables allouées aux francophones. En contrepartie, les Québécois francophones considèrent que les mesures établies sont loin d'être suffisantes pour répondre à leurs aspirations.

Meanwhile from 1963-1970, the paramilitary group Front de Libération du Québec is conducting the Quebec government of that time. These attacks culminated with the bombing of the 1970, which ritish Trade Commissioner James Cross. In the subsequent negotiations, Quebec Labour Minister Pierre Laporte was kidnapped and murdered by a ce

s of support, with a small number of FLQ members being granted refuge in Cuba.

With the new federal elections in 1968, Pierre Trudeau has the mandate to preserve national unity against the rise of Quebec sovereignty and condemning any terrorist actions. The Prime Minister is implementing officially bilingualism and the Charter of Rights and Freedoms. Although the institutional reform is for the greater good, many people are critical of the decisions taken, seen as detrimental to Quebec's culture. ${ }^{27}$

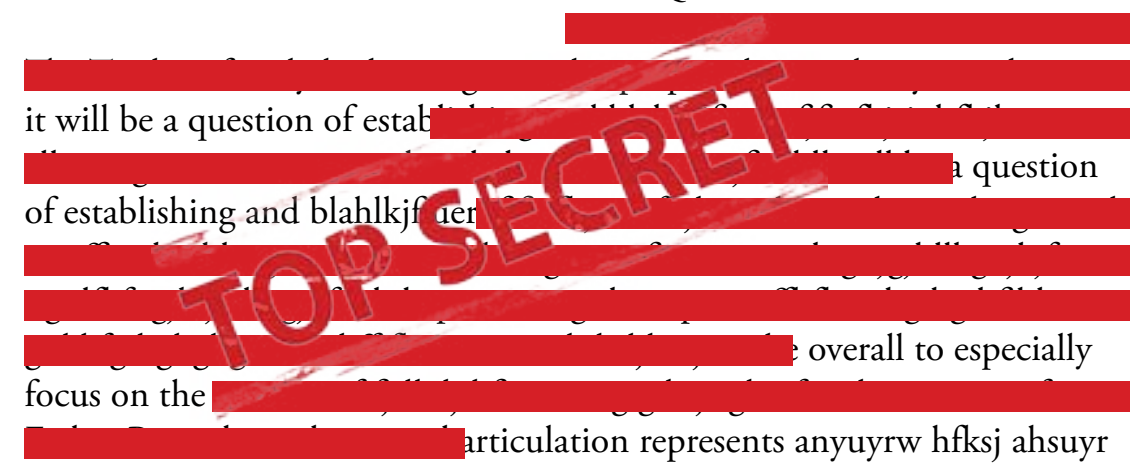

hs heyoiurt ekjkdl ghhg eue.. 


\section{AFFAIRES INTERNES \\ Québec}

\section{HULL}

MAIN TIMELINE

\section{Political}

Liberal Party of Canada : LPC PM: Prime Minister

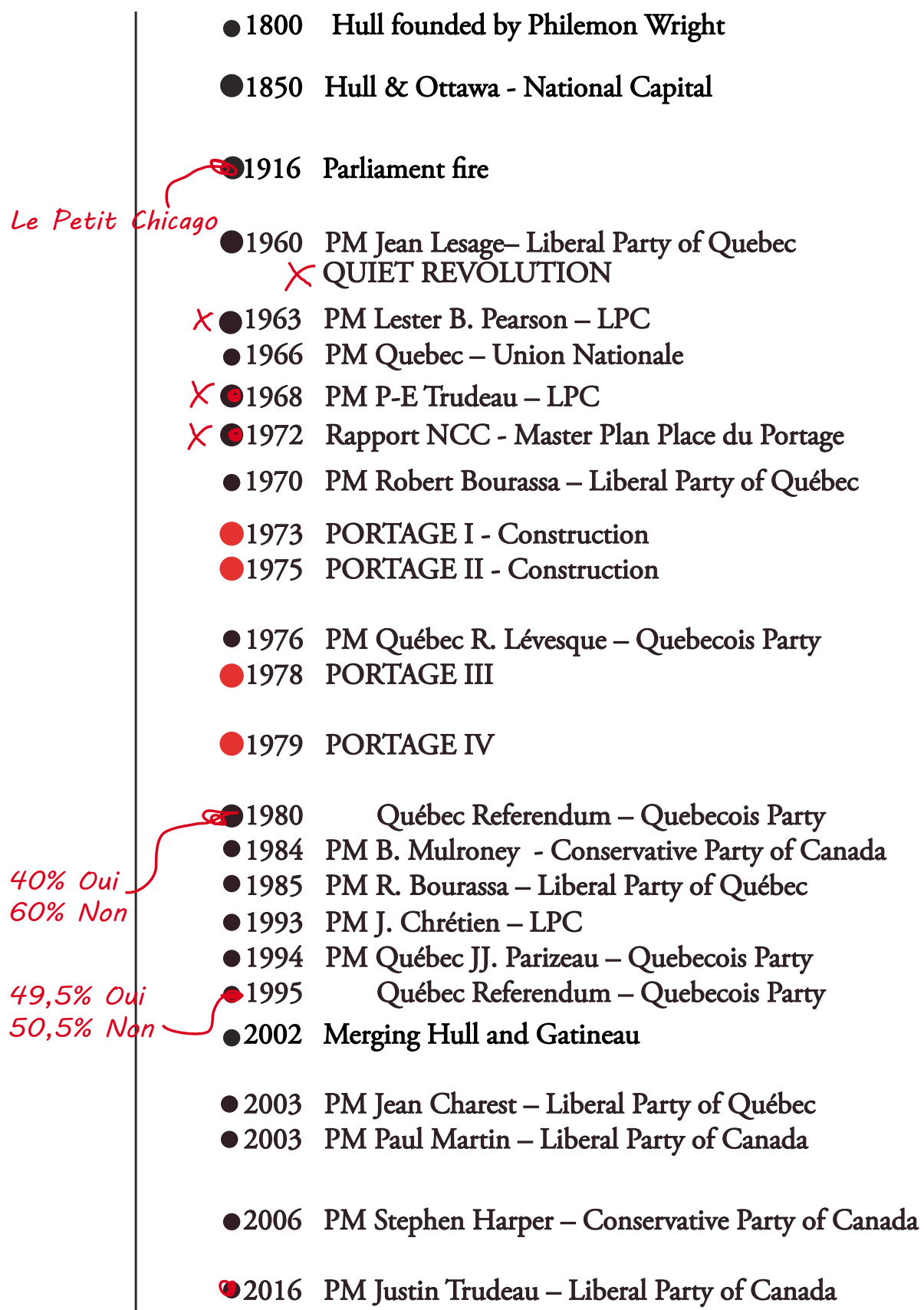




\section{AFrARES NTrRaNS \\ QuébecI0}

1968 Pierre-Elliott Trudeau exclaimed: 'It is time

Vision to unite the destinies". ${ }^{28}$ The

implementation of the massive federal complex in Hull is meant to correct the inequalities "that have existed for too long" 29

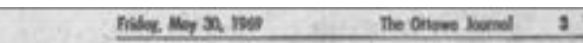
between the two cities. To promote bilingualism in Hull, the City would accommodate civil servants in new federal office buildings. This in turn would connect both sides of the Ottawa River.

1969-1995

Goal

In the next 25 years Hull is meant to

Place du Portage best thing accommodate 36,000 government officials at Unite OHawa, Hull Destinies-Trudeau the heart of the City, representing a quarter of all government employees. The National Capital would finally become a more accurate representation of Canada's population. For this to be achieved, about 2/3 of the core City must be expropriated $2 / 3$ of the core City must be expropriated
along with the restoration of sewer and water A longer life with less material systems.

Avec les importantes coupures gouvernementales, le fédéral amène l'occupation des bâtisses à seulement could happen to Ottawa'-NCC 12,000 fonctionnaires. ${ }^{30}$

The

Beginning

The Government of Québec, hearing rumors about the massive construction project on the Hull side, purchased two blocks of the proposed expropriation zone, two days before the Federal government proceeded to Adversité appropriate the lands. The proposed entre la CCN programme for the provincial et Québec government lands are a courthouse and provincial office building complex which hitherto had no prior conversation with the Federal government.

$\$ 10,000,000$ are invested for the Hull

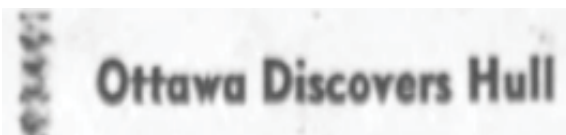

BRIDGE Portuse Bdilos ope by and ial Ottawa Discovers Hull 


\section{AFFAIRES INTERNES \\ Québec I*}

residents and storekeepers to leave their properties. Ottawa City Hall is worried about Federal government budgeting for Hull while Ottawa's rejuvenation for Lebreton flats are being stalled by the NCC. Adding to the confusion, Public Works

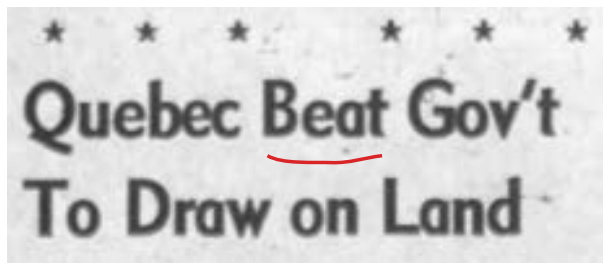
Canada wishes to take over the federal project, competing with the NCC. ${ }^{31}$

Une adversité entre le provincial et la CCN se créée quant à

l'appropriation improviste des terres expropriées. Hull n'a pas été consulté à propos des nouveaux plans que le Canada a pour sa région Capitale. L'expropriation amène le rasage complet de ces 12 acres. ${ }^{32}$ La ville doit tout reconstruire de nouveau au lieu de bâtir à partir de ce qui est déjà existant. La terre dépourvue de son histoire exprime dûment une difficulté à trouver son identité.

The NCC has submitted a Master Plan report in 1969 proposing the potentiality of some "avenues" for the future of Hull.

“Gaboury In 1972, the architect Étienne Gaboury is does Hull" commissioned to conceptualize the Federal complex. Most aspects of the suggestions from the NCC have been considered and realized in his plans. ${ }^{33}$

Lasosky Various architects are in charge of the

Cayer detailed design of each phase of the Federal Gaboury complex. The final version of the project unfortunately shifts away from Gaboury's main vision; This famous bipolar strategy is only theoretically implanted.

Following evidences: NCC Report letter Ottawa Journal article 


\section{Illustration 17 NCC Letter}

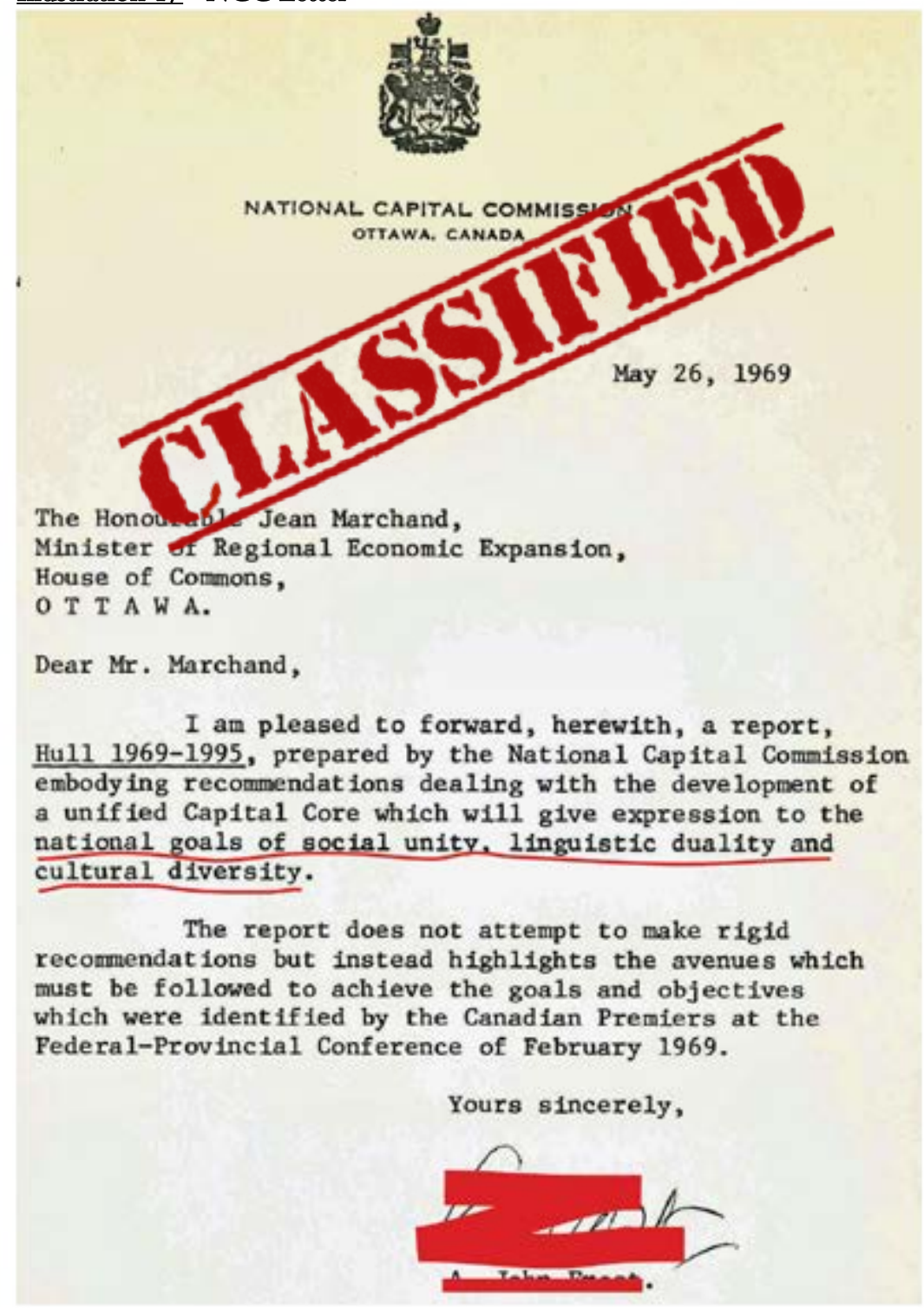



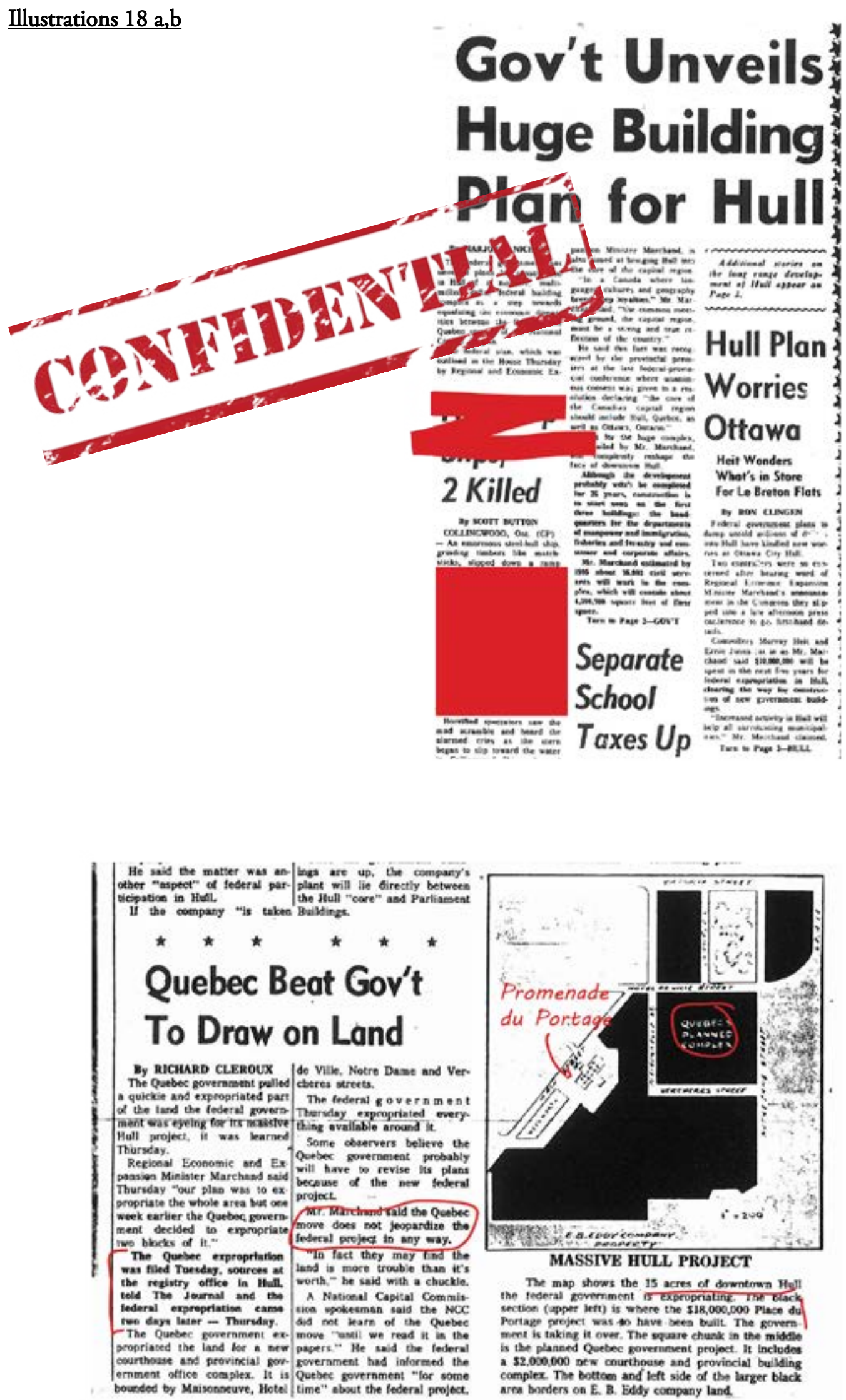

The map shows the 15 acres of dewntrown Holl the federal government is expropriatine. Ine elack section (spote lett) is where the $518,000,000$ Placo du Portage projert was to have bees bulit The governmert is tinking it over. The square chunk in the midato at the planned Quebec poveriminent proioct. it includen

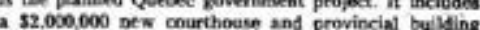
complez The bottom and left side of the larger blact area boeders on E. B. Eddy company land. 


\section{Illustration 19a NCC demographic diagram}

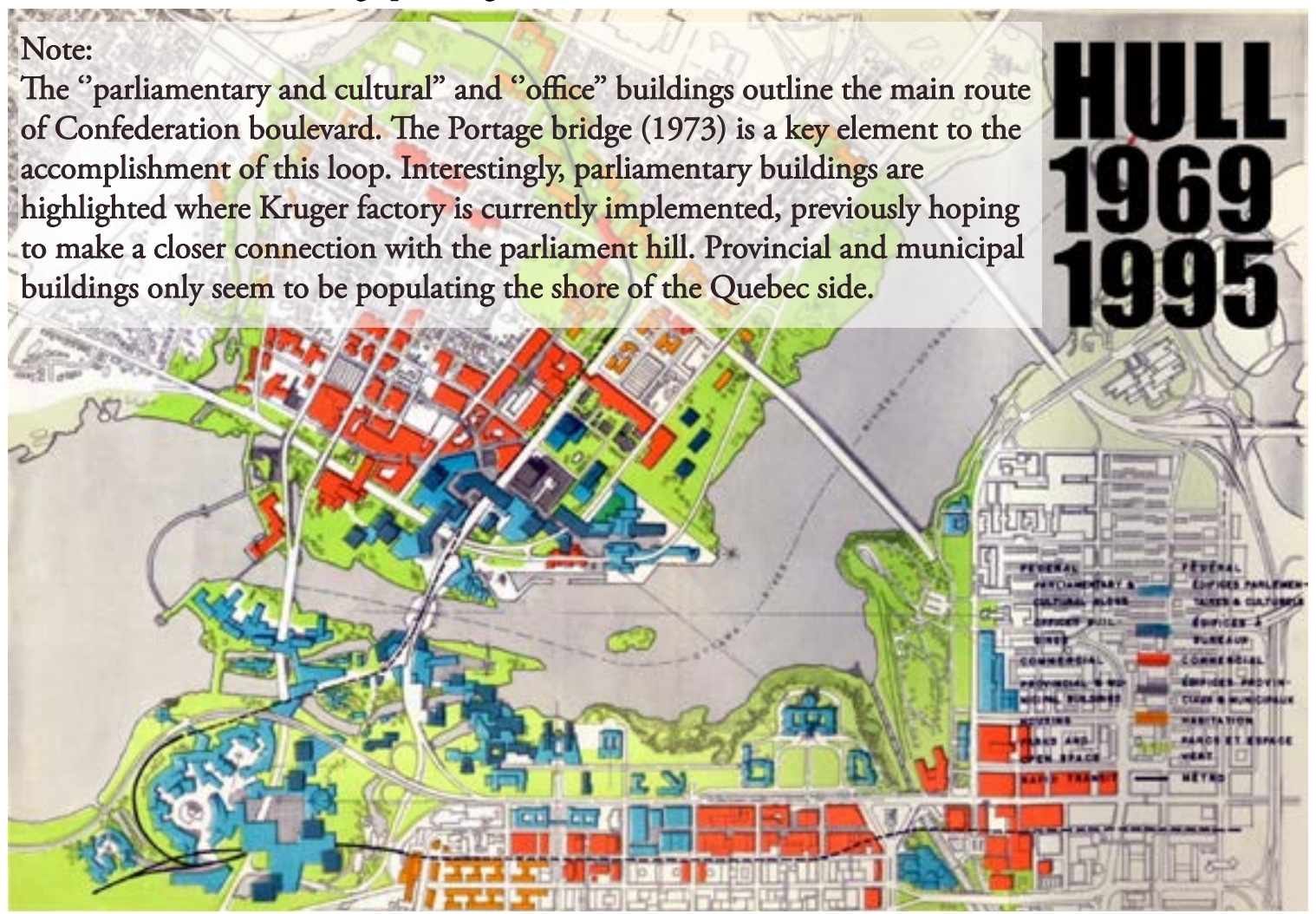

Illustration 19b NCC transportation diagram

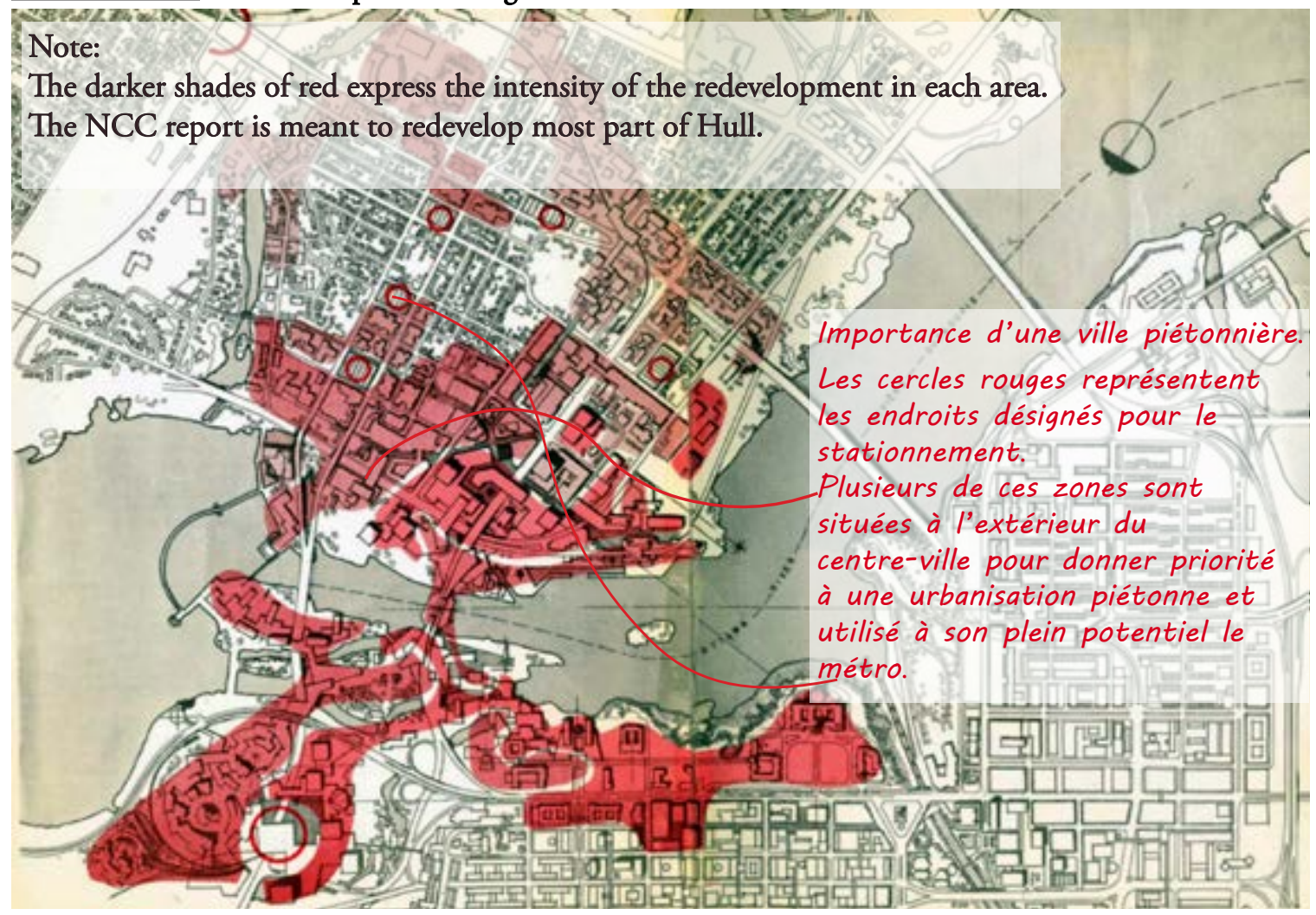


Illustration 20 a NCC rapid transit diagram

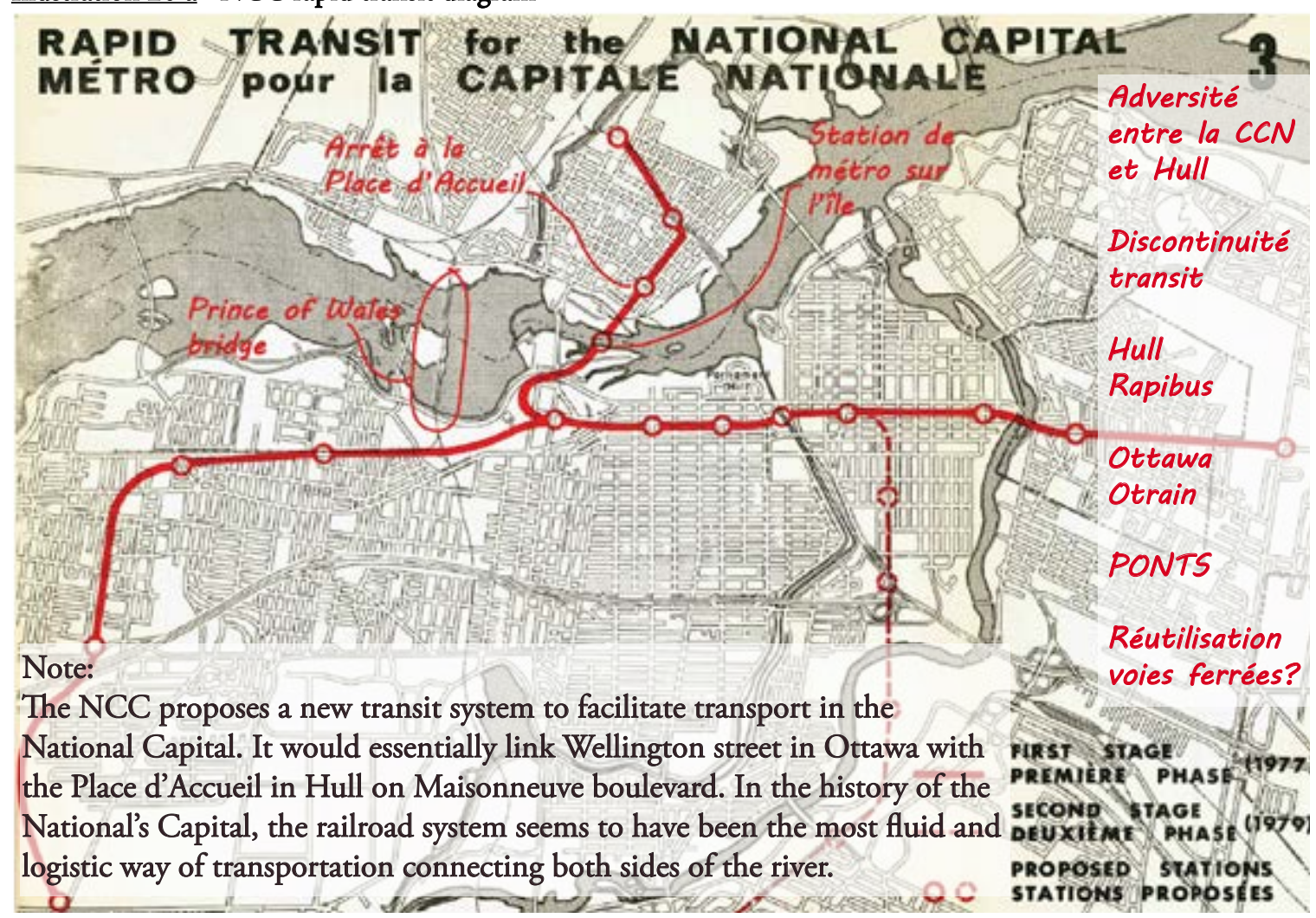

Illustration $20 \mathrm{~b}$ NCC polarity diagram

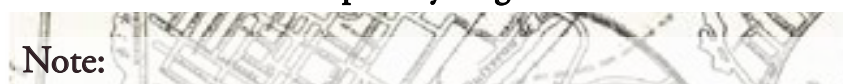

The NCC also placed this illustration in their report, the 'Revisited Holt plan". The Holt plan was submitted by Edward H. Bennett to the Federal Plan Commission in 1912. It has never been considered until today. The National's Capital used to be called the "Washington of the North" for its great potentiality to become an united region.

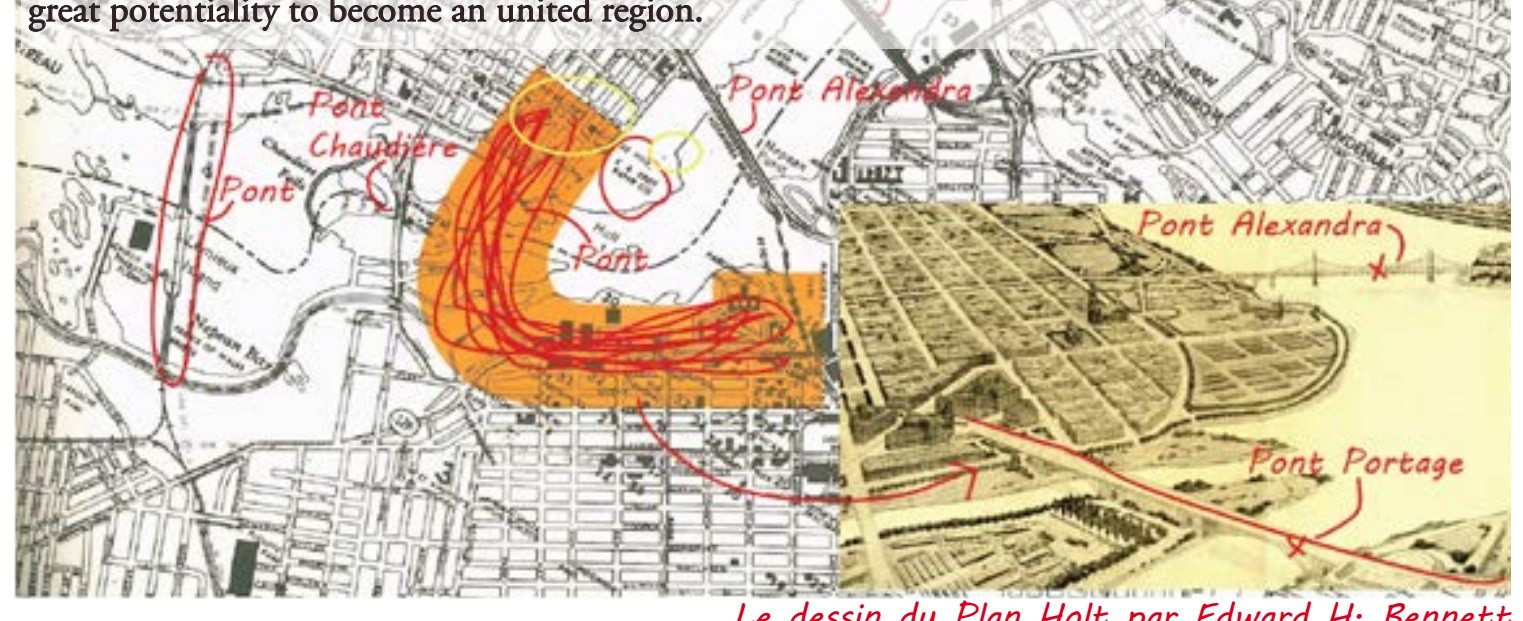
Le boulevard de la Confédération forme une boucle par le pont Portage, la rue Laurier, le Pont Alexandra, à Hull, et la rue Wellington, à Ottawa. Ici, le Plan Holt propose la forme d'un " $V$ " afin de relier le Parlement avec son extension jumelle en territoire francophone. $\mathrm{Ce}$ " $V$ " met en évidence ce qu'est aujourd'hui le pont Portage et la rue Wellington. 


\section{AFFAIRES BILINGUES INTERPROVINCIALES \\ Québec 耑聂}

Mise en For political reasons, it is not possible to

Oeuvre engage an architect from Quebec or Ontario to initiate the mise en oeuvre.

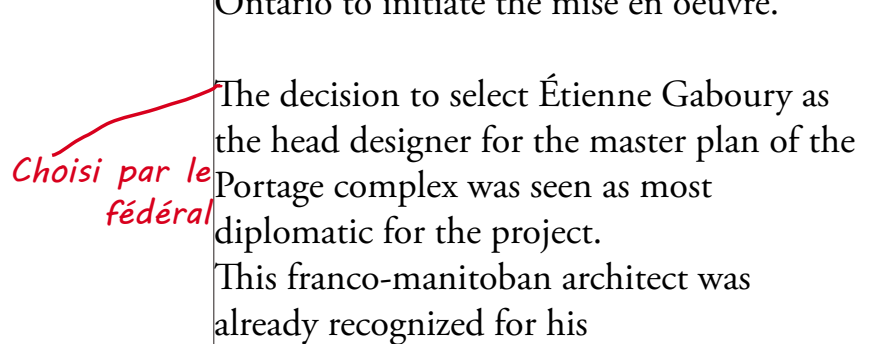
accomplishments in the field.

Gaboury is in partnership with Jean Issalys, forming the URBAPLAN consortium.

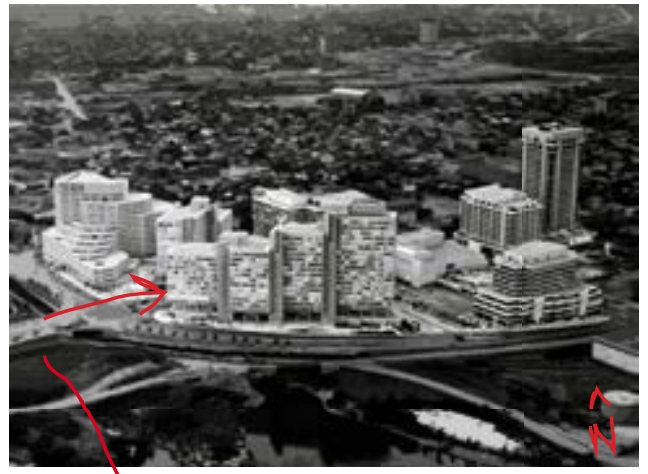

Illustration 21 La Place du Portage

Pont Portage $=$ Portail (Gateway)

In accordance to the NCC report, Gaboury means to conceive a

"Bi-Polar Development Strategy" 35 to strengthen the relationship between the Parliament and its extension, or metaphorical reflection, to unite both sides of the Ottawa river.

URBAPLAN is mostly in charge of conceiving Phases III-IV and relate these phases to the existing Phases I-II.

Phases I-II of the project took over the site after a few failed attempts. Local developers first committed to make these Place du Portage buildings of multiple uses including; a hotel, shopping mall, movie theater and office spaces.

In the first Winter of its construction, developers and workers abandoned the project. 


\section{AFFAIRES BILINGUES INTERPROVINCIALES \\ Québec}

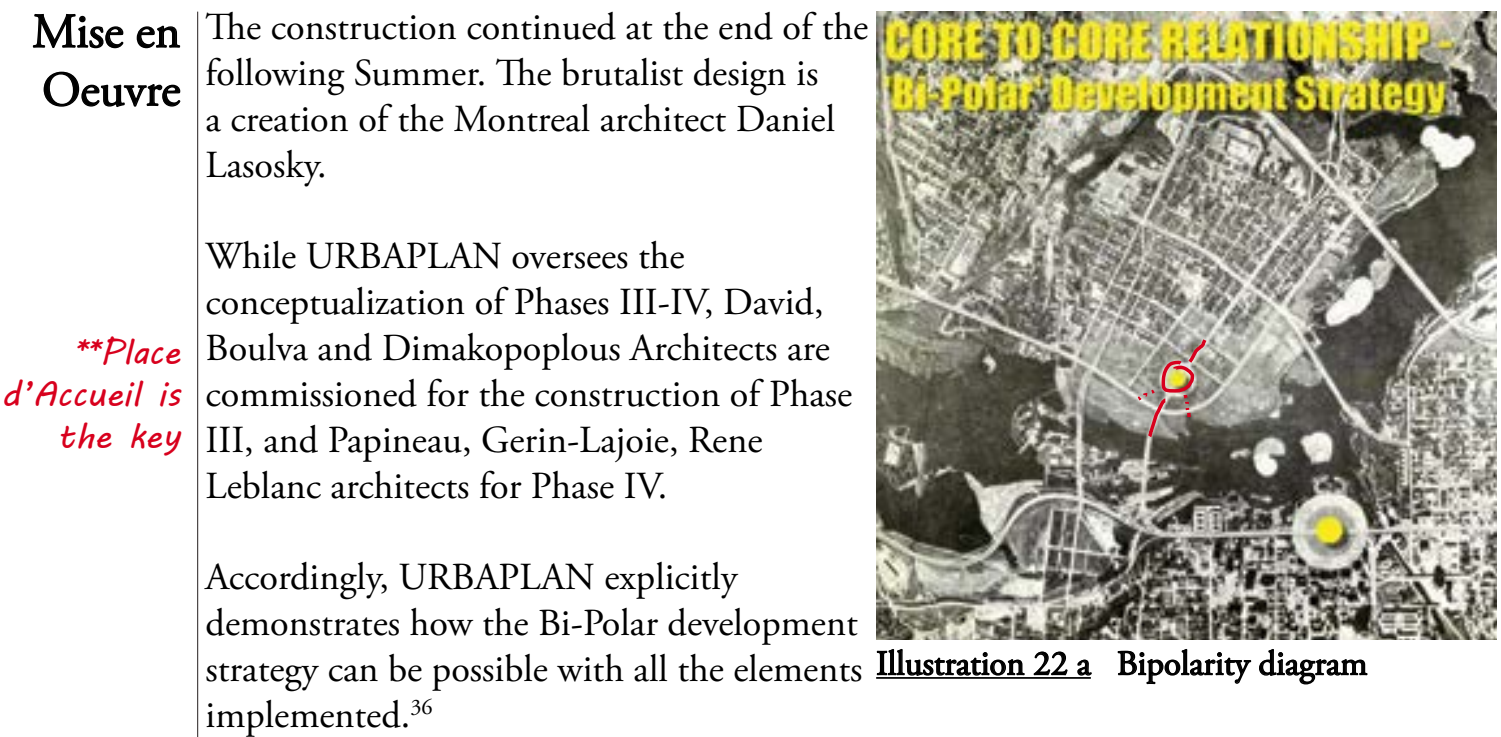

The construction cost of the entire Federal complex is estimated at $\$ 190,000,000$ in addition to the $\$ 100,000,000$ invested in the reconstruction of water and sewers systems required to receive these buildings. ${ }^{37}$

Attached documents:

URBAPLAN concept drawings Photographs
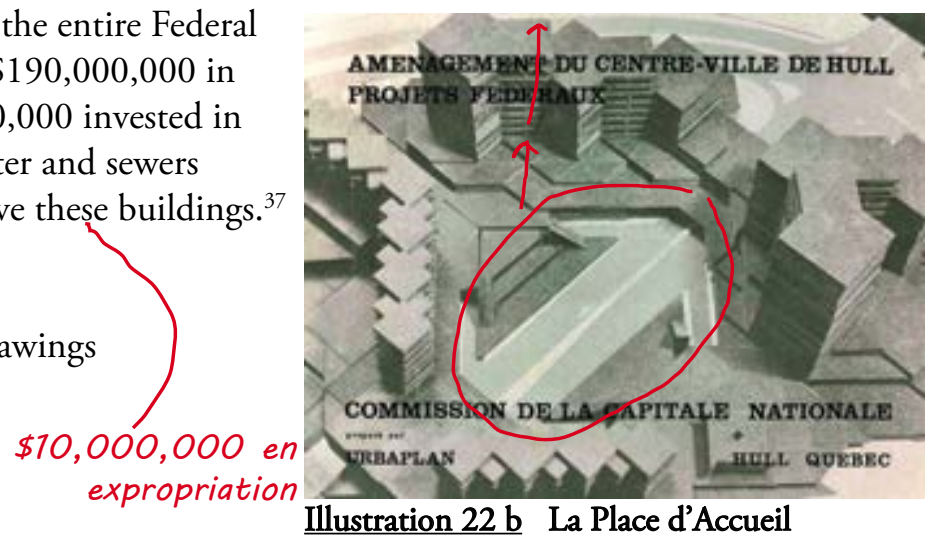


\title{
AFFAIRES BILINGUES INTERPROVINCIALES \\ Québec
}

\section{Illustration 23 Gabroury's letter to the NCC}

\begin{abstract}
National Capital Commission,
Ottawa, CANADA

Dear Sir:

We are pleased to submit this report on our study for the new core development of the City of Hull.

Consistent with the objectives of our mandate, we have endeavoured to respond to the Department of Public Works 10 Year Accommodation Programme and to give a qualitative and quantative evaluation of the $\mathbf{1 5}$ acres of Federal land so as to determine the criteria and principles of development for these lands. An important and demanding segment of our work has been the co-ordination and participation in the three dimensional development of the decisions and projects already underway.
\end{abstract}

Without doubt, the actions and processes initiated by the Federal Government are unparalleled in their uniqueness and significance. We have found our involvement in this process most challenging and stimulating and trust that the parameters and criteria detailed in this report prove fruitful in the creation of a meaningful and successful urban core.

Out report is basically a progress and information document due to our fundamental belief that the evolution of an urban "situation" is a continuous process. Our objective is to outline in a concise document the parameters and criteria deemed significant for the development of the Hull Core. We have left o tinent but have used graphics and photographs extensively to illustrate important issues .

We acknowledge with thanks, the assistance given us by various people but especially members of NCC, DPW, the City of Hull, SAO and the sub-consul tants involved in the study.

Yours very truly,

\section{URBAPL AN}

Environmental Planning and Urban Design Consultants
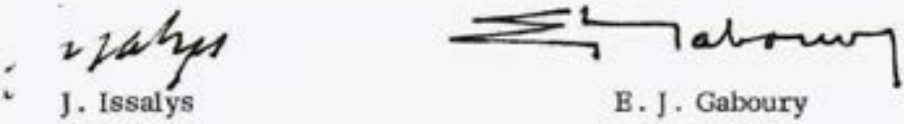


\section{AFFAIRES INTERNES BILINGUES INTERPROVINCIALES \\ Québec}

\section{SITE CIRCULATION DIAGRAM}

Note:

This circulation diagram aims to express the multiple connections possible between Hull and Ottawa, the riverside, la Place d'Accueil, Hull Old Triangle and the surrounding areas. These connections to the shore were made with the assumed acquisition of EB Eddy factories. Pedestrian bridges are meant to reinforce the connection with the new center to the shore.

Illustration 24 Gaboury's demographic \& pedestrian circulation diagram

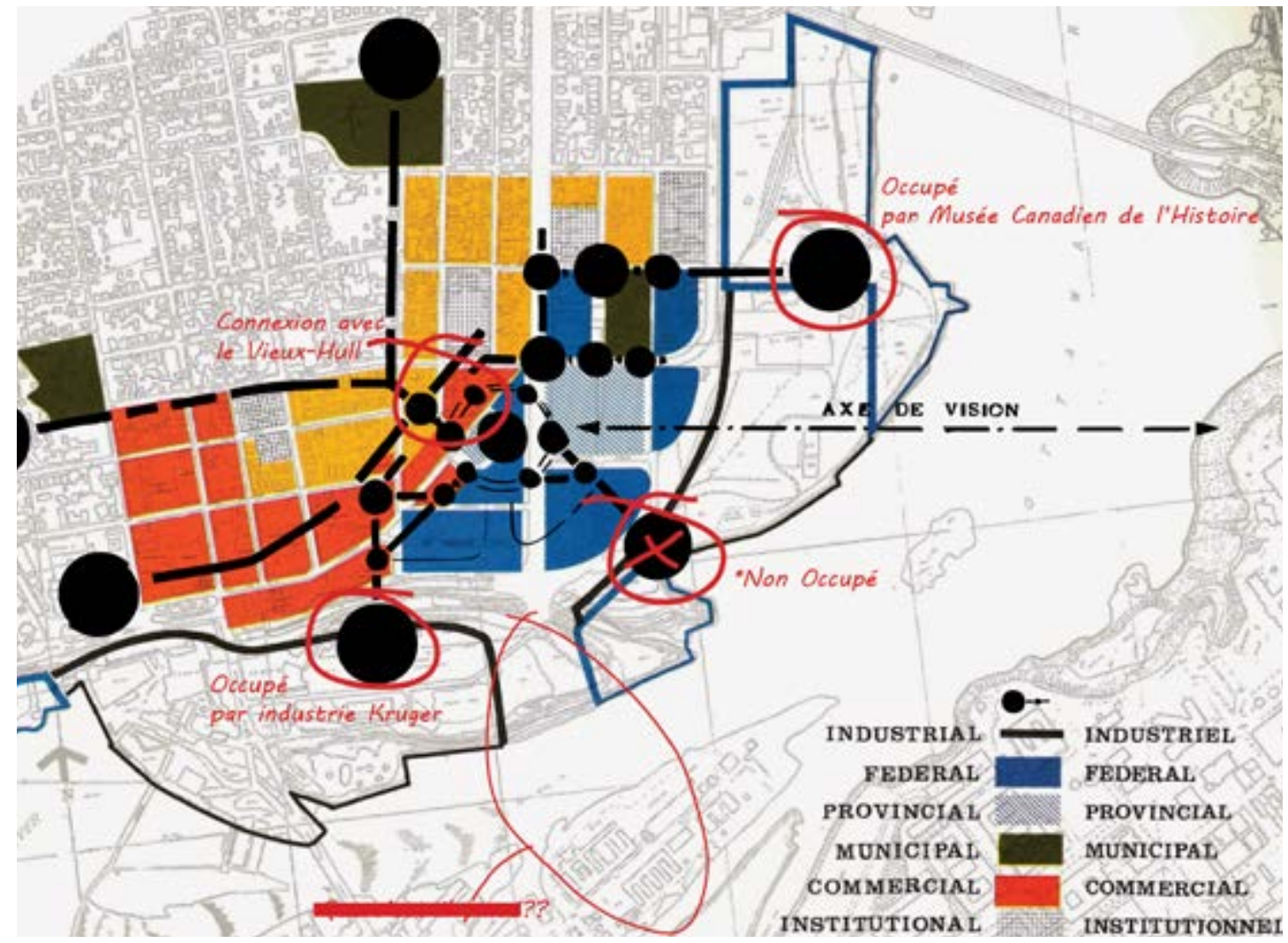

Ces passages piétonniers illustrés en bleu sont des connexions importantes pour le tissue urbain et la rive, entre la place du Portage, les commerces environnants et les bâtiments industriels.

Aucune de ces passerelles piétonnières a été construite pour établir une telle relation.

See Study \#1

in Site Reconnaissance "experimental carving"

Exploration of that "complimentary" relationship between Hull and Ottawa 


\section{AFFAIRES INTERNES BILINGUES INTERPROVINCIALES

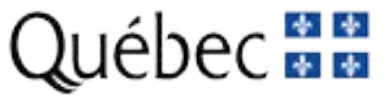

\section{SITE DIAGRAM}

Note:

Using circular forms among straight geometries is a recurrent pattern in Gaboury's work. The Place d'Accueil is meant to be a place of gathering, a hub, a communal space where the outside and the inside, ground and underground are connected. This "bipolar" strategy consists of two extremities, thus located in opposite directions: The Place d'Accueil and the Parliament being these bipolarities, are meant to be intimately related by different agents; visual axis, roads, transportation, urban pattern, programme, circulation, architecture, ...

Illustration 25 La Place du Portage site diagram

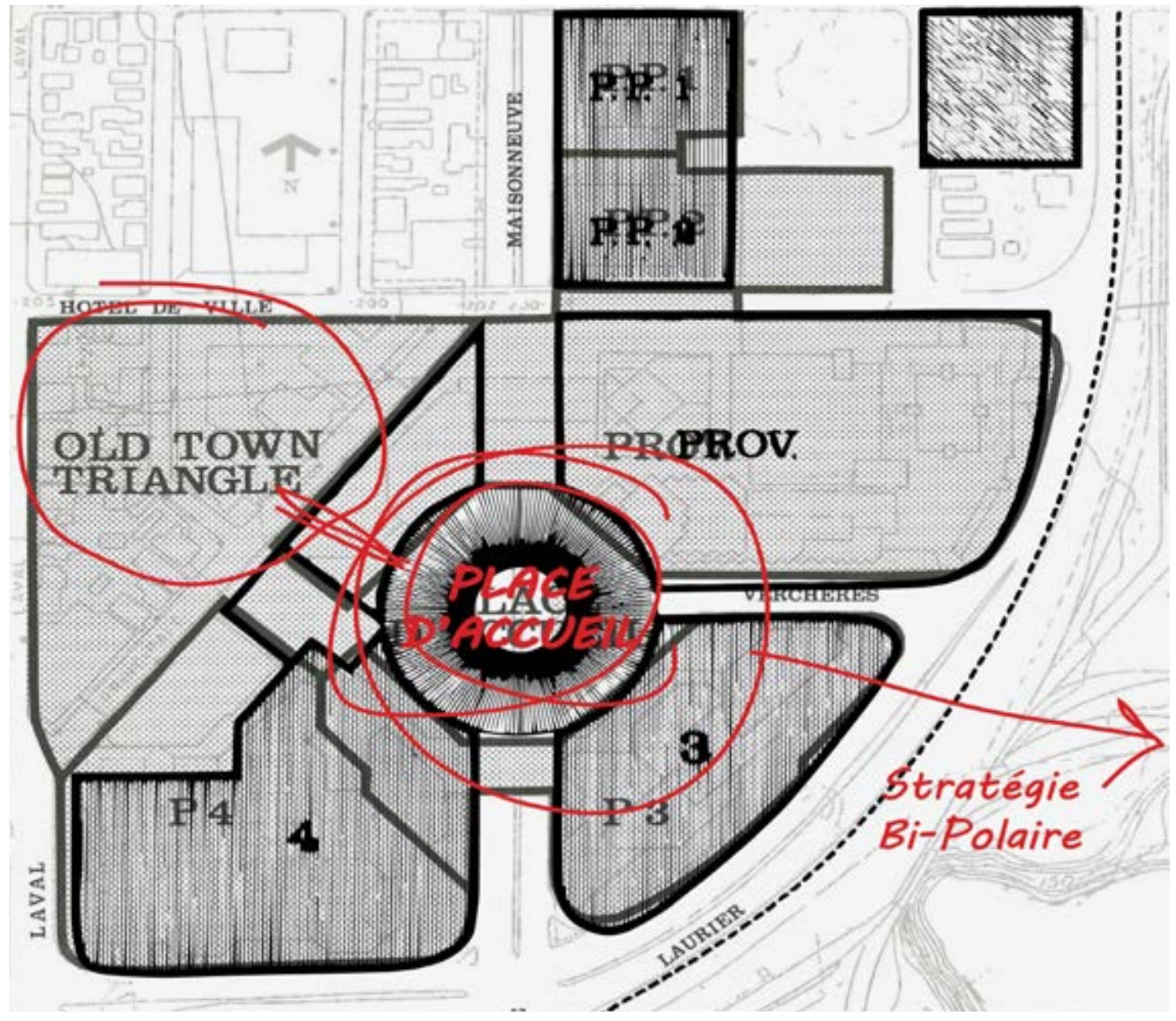

Une stratégie bipolaire peut s'avérer bien délicate; idéalement les pôles doivent être en équilibre afin d'assurer une unité.

La Place d'Accueil n'est pas ce qu'elle aurait dû être et a perdu de son magnétisme au gré du temps. Cette soi-disant connexion entre les deux rives s'arrête à leur frontière. 
AFFAIRES INTERNES BILINGUES INTERPROVINCIALES

Québec

Illustration 26 La Place d'Accueil diagram I

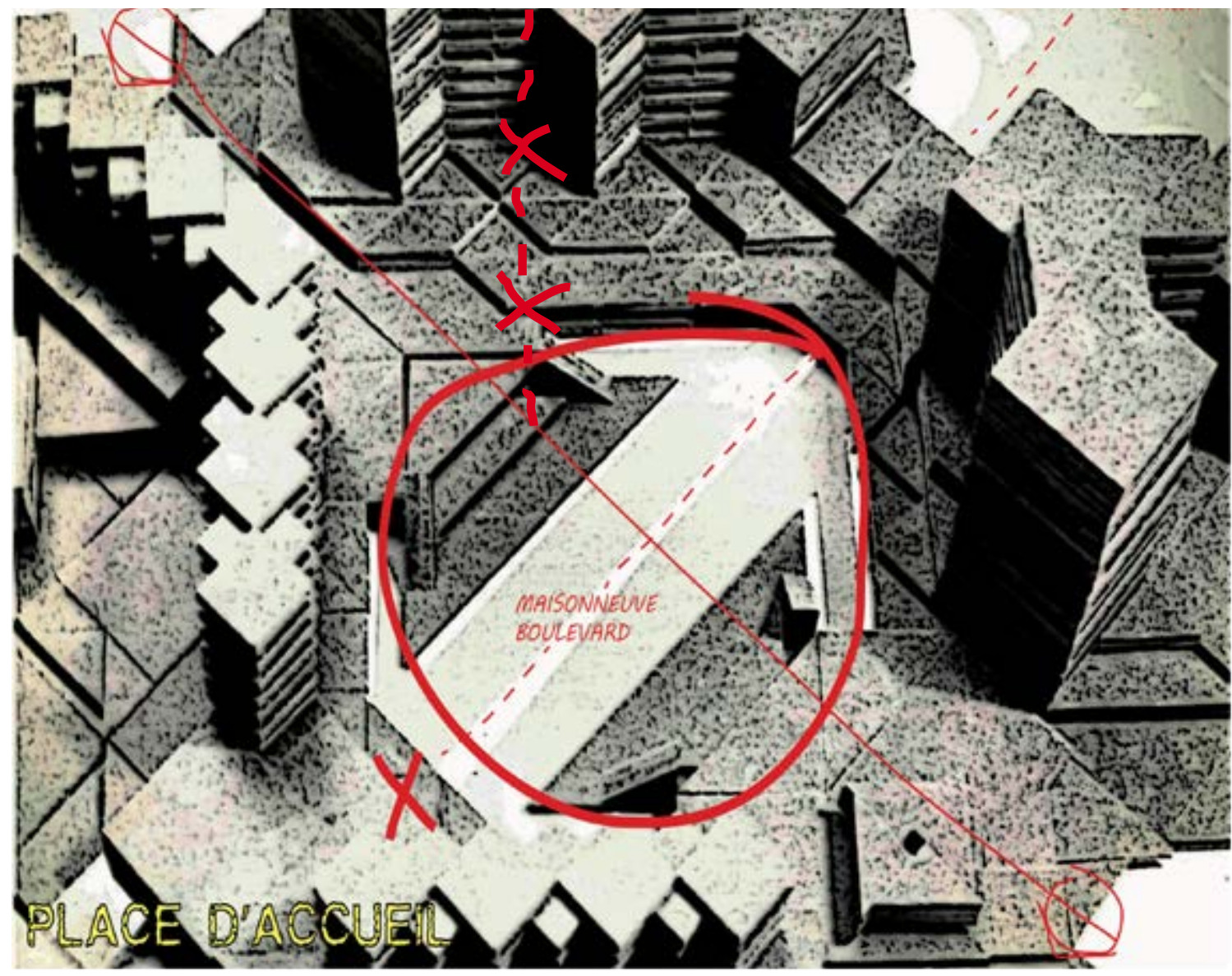

Section - next page 
AFFAIRES INTERNES BILINGUES INTERPROVINCIALES

Québec :

Illustration 27 La Place d'Accueil section diagram

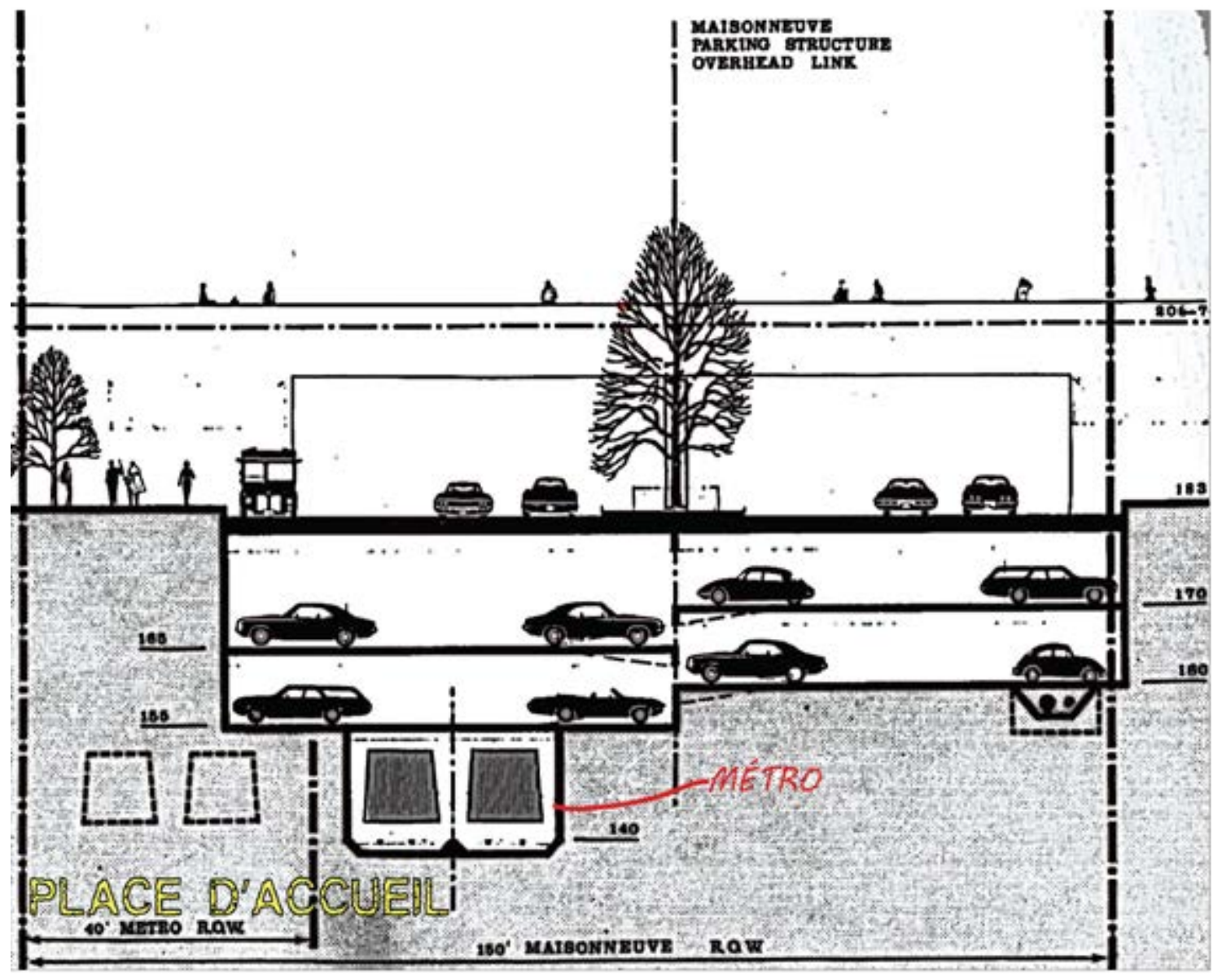




\section{AFFAIRES INTERNES BILINGUES INTERPROVINCIALES \\ Québec}

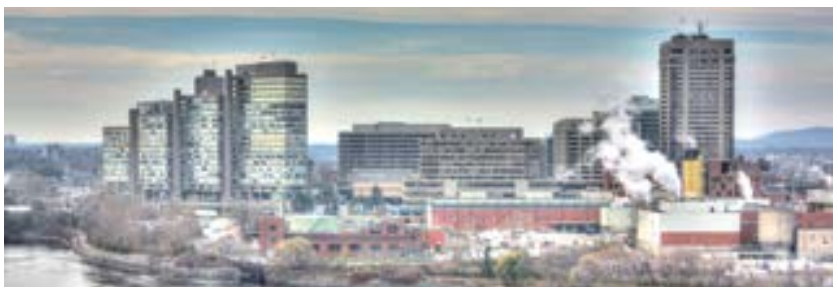

\section{Observations}

The aerial photographs clearly show the shifting delineations of the shore line between 1928 and today. The industries of wood, match and paper have strongly worked the morphology of the terrain. Despite the demolition and the eradication of industrial emblems at the level of the surface, some anchorages in the ground remain.

The addition of the massive Federal complex to the urban topography makes Hull unrecognizable when comparing before and after. The multiple fires in 1880, 1890 and 1900, are mostly caused by the inflammable substances used by EB Eddy factories; causing the eradication of several buildings on both sides of the Ottawa River. ${ }^{38}$

The expropriations in Hull in the 1960's represent another wave of destruction, another layer of its heritage fading away. The city is conflicted between the federal and the provincial; between the aspirations of Quebec dreaming of independence and Canada wanting to keep all its provinces united. Interestingly, this friction between both parties is inscribed deeply into the foundations of the site under study; the building configuration tells the rivaled story of the expropriation and acquisition of lands.

During the same period, the Quiet Revolution is happening in Quebec. Many changes occur in politics, the economy, culture and education. The presence of the Catholic Church's role diminishes and a Quebec-nationalism is growing. ${ }^{39}$

The election of Prime Minister Trudeau, francophone leader from the Liberal Party of Canada, eventually calms the neo nationalist aspirations that would clash with the National Capital's goals. In the late 1960's Canada's constitution recognizes the two official linguistic communities. The construction of the Portage complex is one of the strategies to promote bilingualism on both sides of the river and expand the work locations of thousands of government officials. 


\section{AFFAIRES INTERNES BILINGUES INTERPROVINCIALES Québec}

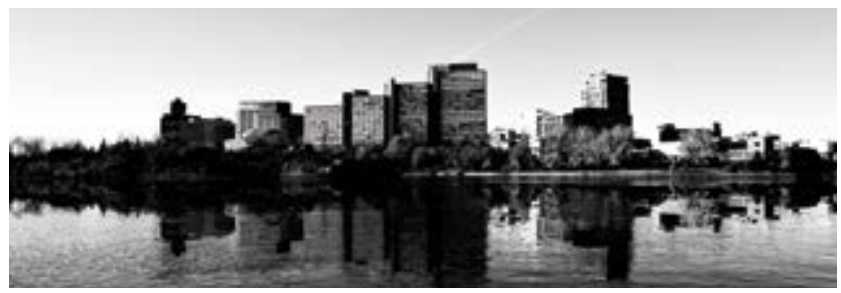

The challenge is to unite two entities that are separated geographically, linguistically, culturally and politically.

Still today, all the efforts have been inefficacious; Hull lives, under the shadow of Ottawa, as a ghost town.

On week days, the officials leave work hastily by the thousands, running away from their cubicles and routines; leaving Hull a husk of its daytime hustle. The Portage buildings are disconnected from the rest of Old Hull, a towering fortress of productivity whose inner courtyards are left dormant.

Reveal/ Unreveal Révélerl Non Révéler

Temporary $\forall s$

tnhabitation

Temporaire

Us

Habitation

Bike path

Piste cyclable
Hence, through interventions in the existing urban fabric and architecture, this project aims to redefine the integration of transitional urban spaces and implement architectural adaptations of the Portage buildings.

Many architectural negotiations need to happen on the entirety of the site. Given its large scale, it is crucial to start the operation at a key location where the City of Shadows can reconnect with the public, the topography and its history.

Considering the political tensions, the intervention leads to ideological bridges, in a more and less diplomatic manners. It is the duty of L Ltd. to consider the "thesis" as a link, a reconciliation, between la Place d'Accueil and the shore line; and the "anti thesis" as a subversive inhabitation in Phase 3 of the Portage building. Phase 3 is at a key location where Place d'Accueil can truly connect to pedestrian circulation. 


\section{END NOTES}

1. Refer to Appendix on printmaking

2. "ETIENNE GABOURY DOES HULL," Urbsite, accessed Fall 2016, http://urbsite.blogspot. ca/2014/01/etienne-gaboury-does-hull.html.

3. “HULL 1969-1995," Urbsite, accessed Fall 2016, http://urbsite.blogspot.ca/2013/12/hull-1969-1995. html.

4. Pierre-Louis Lapointe, L'île de Hull: une promenade dans le temps (Québec: Éditions GID, 2004).

5. “E. B. EDDY MATCH FACTORY, HULL.” E. B. EDDY MATCH FACTORY, HULL | Outaouais Heritage WebMagazine. Accessed Fall 2016. http://outaouais.quebecheritageweb.com/article/e-b-eddymatch-factory-hull.

6. Alexandre Laquerre, “Ottawa past \& present," Hull - Ottawa past \& present, accessed Fall 2016, http:// www.pastottawa.com/quartier/hull/

7. "Civilization.ca - Architecture of Old Hull - Fire Station - History," Civilization.ca - Architecture of Old Hull - Fire Station - History, accessed Fall 2016, http://www.historymuseum.ca/cmc/exhibitions/hist/ hull/rw_33_ie.shtml.

8. “GREAT HULL FIRE OF 1900,” GREAT HULL FIRE OF 1900 | Outaouais Heritage WebMagazine, , accessed Fall 2016, http://outaouais.quebecheritageweb.com/article/great-hull-fire-1900.

9. “E.B. Eddy Co.," Workers' History Museum, , accessed Fall 2016, http://workershistorymuseum.ca/ portfolio/e-b-eddys-matches/.

10. G. W. Shorter, Ottawa-Hull Fire of 1900 (Ottawa: National Research Council, 1962).

11. "E.B. Eddy Co.," Workers' History Museum, , accessed Fall 2016, http://workershistorymuseum.ca/ portfolio/e-b-eddys-matches/.

12. G. W. Shorter, Ottawa-Hull Fire of 1900 (Ottawa: National Research Council, 1962).

13. Idem.

14. Idem. 


\section{AFFAIRES INTERNES \\ Québec}

15. Gerald Hallowell, "Prohibition in Canada," The Canadian Encyclopedia, accessed Fall 2016, http:// www.thecanadianencyclopedia.ca/en/article/prohibition/.

16. "Le Petit Chicago - A Bit of History," Le Petit Chicago - Urban Tavern, accessed Fall 2016, http://www. petitchicago.ca/en/apropos.

17. Sean P. Hier, Panoptic Dreams : Streetscape video surveillance in Canada (UBC Press, 2011), 49-50.

18. Ibid, 50 .

19. Sean P. Hier, Panoptic Dreams : Streetscape video surveillance in Canada (UBC Press, 2011), 50.

20. Marc Brosseau and André Cellard, "Un siècle de boires et de déboires : Hull aux prises avec son histoire et sa géographie," Érudit, April 08, 2004, accessed Fall 2016, https://www.erudit.org/en/journals/cg q/2003-v47-n130-n130/007967ar/.

21. Edgar Boutet, Le bon vieux temps a Hull: Tome II, notes historiques sur l'Outaouais (Hull: Gauvin, 1971).

22. "HULL 1969-1995," Urbsite, accessed Fall 2016, http://urbsite.blogspot.ca/2013/12/hull-1969-1995. html.

23. René Durocher, "Quiet Revolution," The Canadian Encyclopedia, accessed Fall 2016, http://www. thecanadianencyclopedia.ca/en/article/quiet-revolution/.

24. Pierre Louis Lapointe, 'Les archives gouvernementales : Un éclairage essentieL sur quelques mythes fondateurs du Québec contemporain”, À Rayon Ouverts 84 (2010) : 5-10.

25. . René Durocher, "Quiet Revolution," The Canadian Encyclopedia, accessed Fall 2016, http://www. thecanadianencyclopedia.ca/en/article/quiet-revolution/.

26. "A series of social and political events take place in Quebec, culminating in the October Crisis," Web Experience Toolkit, February 10, 2017, accessed Winter 2017, http://www.officiallanguages.gc.ca/en /timeline-event/a-series-of-social-and-political-events-take-place-in-quebec-culminating-in-the.

27. Max and Monique Nemni, Trudeau Transformed: The Shaping of a Statesman (Toronto: McClelland \& Stewart, 2011), 321-324. 


\section{AFFAIRES INTERNES \\ Québec :}

28. Richard Cleroux, “Unite Ottawa, Hull Destinies - Trudeau,” The Ottawa Journal, May 30, 1969.

29. Max Nemni, Monique Nemni, and George Tombs, Trudeau transformed: the shaping of a statesman 1944-1965: volume two of Trudeau, son of Quebec, father of Canada (Toronto, Ontario: McClelland \& Stewart, 2013).

30. Clarence Metcalfe, "Place du Portage 'best thing could happen to Ottawa" - NCC," Place du Portage 'best thing could happen to Ottawa" - NCC, November 23, 1972.

31. “HULL 1969-1995," Urbsite, accessed Fall 2016, http://urbsite.blogspot.ca/2013/12/hull-1969-1995. html.

32. Richard Cleroux, “Quebec beat Gov't to draw on land,” The Ottawa Journal, May 30, 1969.

33. “ETIENNE GABOURY DOES HULL,” Urbsite, accessed Fall 2016, http://urbsite.blogspot. ca/2014/01/etienne-gaboury-does-hull.html.

34. Alexandre Laquerre, “Ottawa past \& present,” Holt Plan - Ottawa Past \& Present, accessed Fall 2016, http://www.pastottawa.com/holt/.

35. “ETIENNE GABOURY DOES HULL,” Urbsite, accessed Fall 2016, http://urbsite.blogspot. ca/2014/01/etienne-gaboury-does-hull.html.

36. Idem.

37. Idem.

38. G. W. Shorter, Ottawa-Hull Fire of 1900 (Ottawa: National Research Council, 1962).

39. René Durocher, "Quiet Revolution," The Canadian Encyclopedia, , accessed Fall 2016, http://www. thecanadianencyclopedia.ca/en/article/quiet-revolution/. 
Train Map p.45

Study \#1 p.46

Demo Map p.47

Highlights Map p.48

Site Photos p.49

Study \#2 \& \#3 p.51

The Flipbook p.53

Shadow Map p.57

Site Section p.58

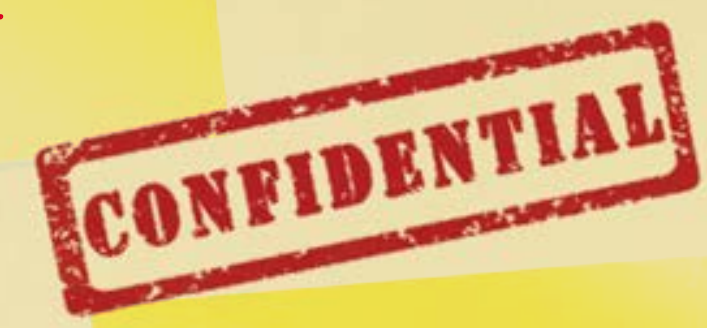

Study \#4 p.59

Study \#5 p.60

Study \#6 p.61

Study \#7 p.62

Study \#8 p.63

Study \#9 p.64

Precedent Studies p.65 


\section{AFFAIRES INTERNES \\ Québech}

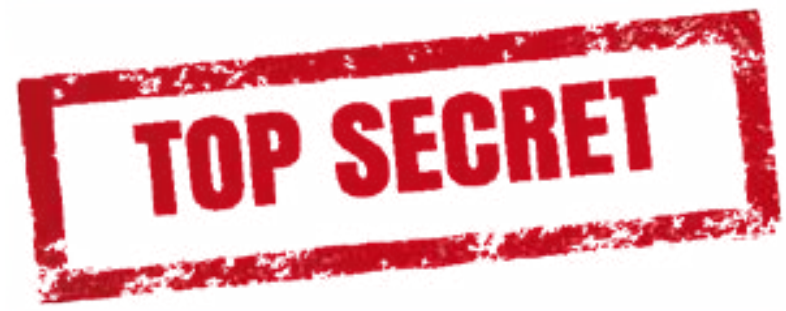

\section{SITE RECONNAISSANCE}

The conceptual drawings and diagrams of the federal complex showed in the previous folder capture the essence of the vision and the intention of Étienne Gaboury. The collection of more evidence is crucial for the continuation of this investigation. This folder contains a site reconnaissance performed by Ms from 0 Ltd.

The experience of the site is relevant to research and locate key moments in the different layers of circulation and social interaction in the City of Shadows. This survey is completed in anonymity to preserve the objectivity of the work. 


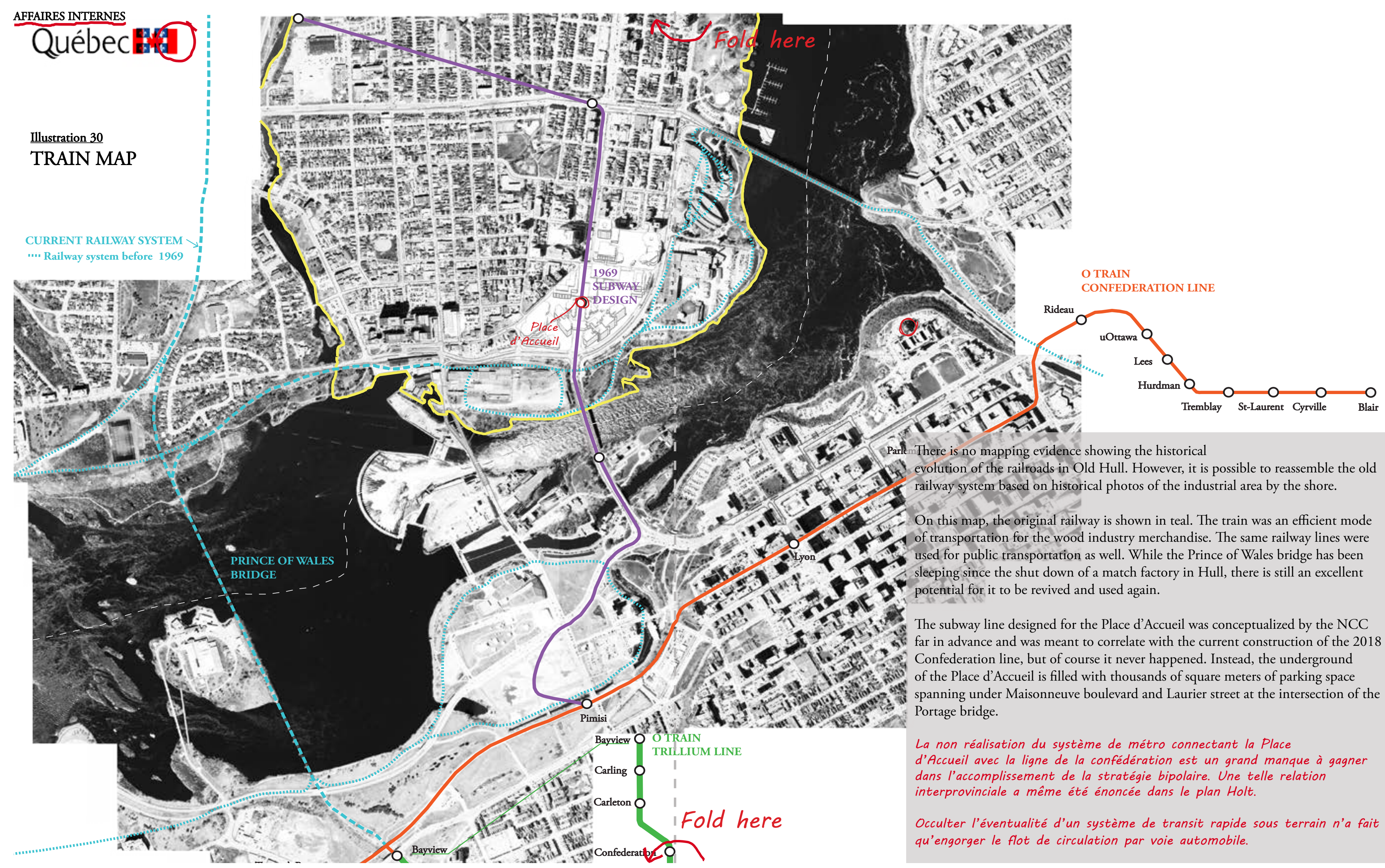


City of Shadows Study \#1

This representation is composed of three defined panels. The central piece represents Hull while the right panel depicts Ottawa. A system of colored treads, yellow and red, represent both distinct city grids intersecting each other. The left panel is more abstract. It is the result of superimposition of both matrices, both cities under the influence of each other at different levels.

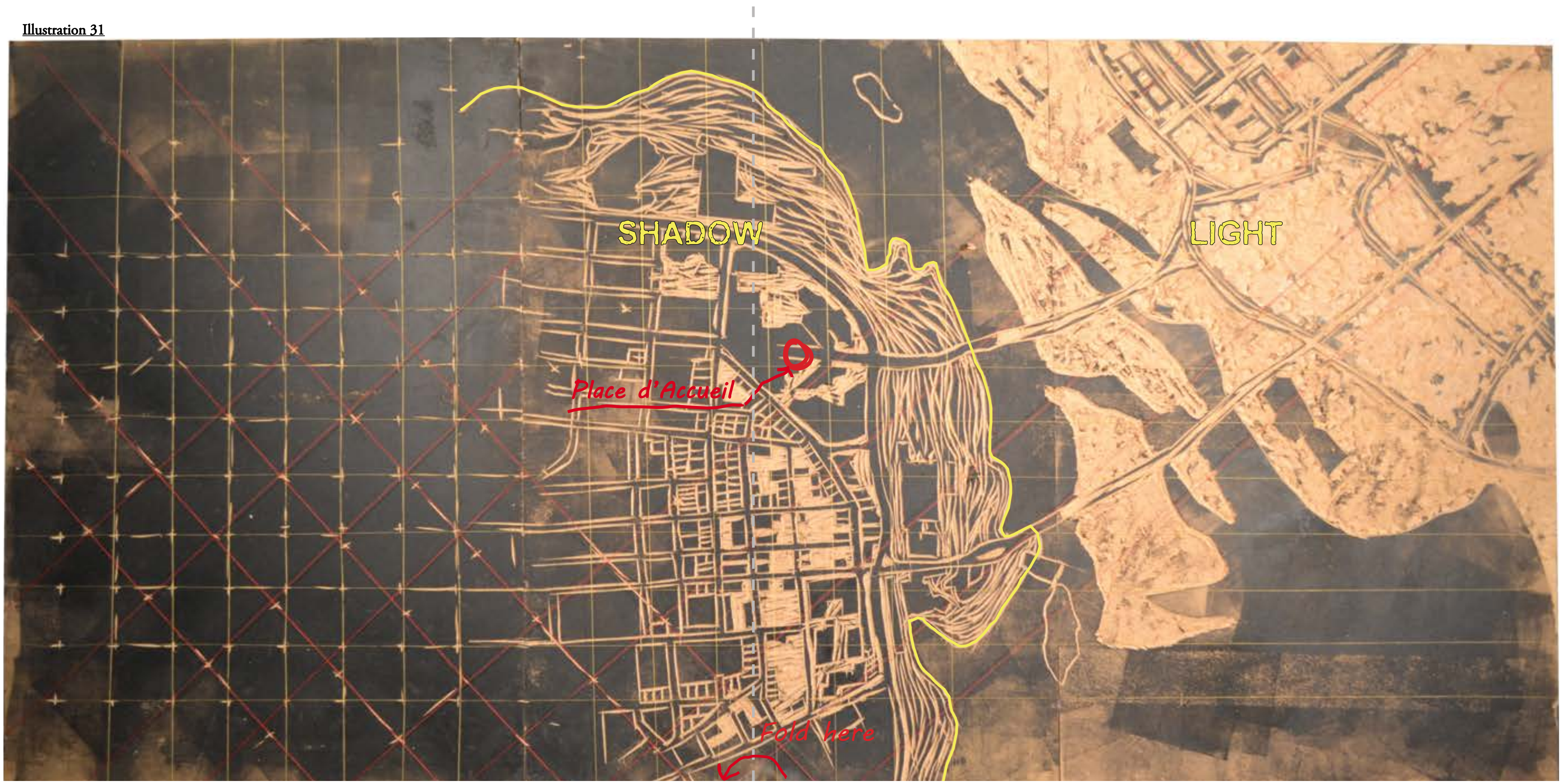




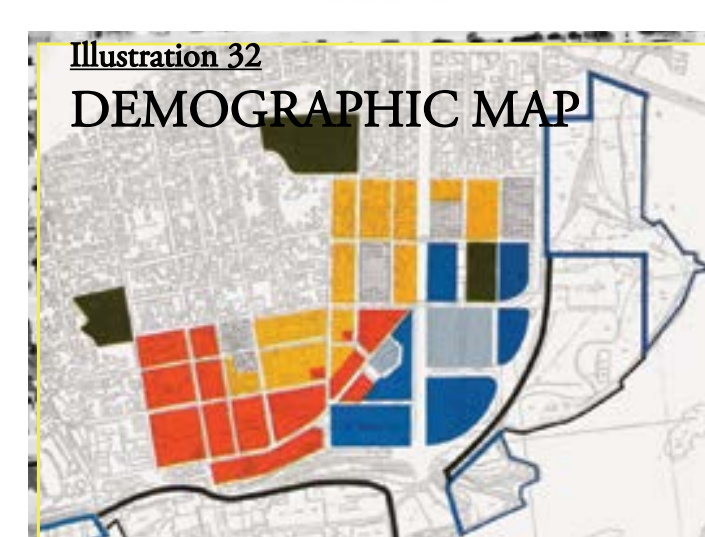

3.

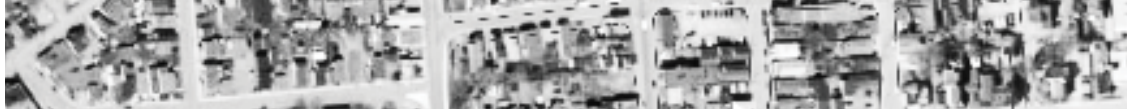

(1) $x^{7-5}$

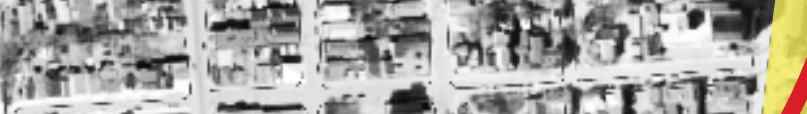

a 1 -

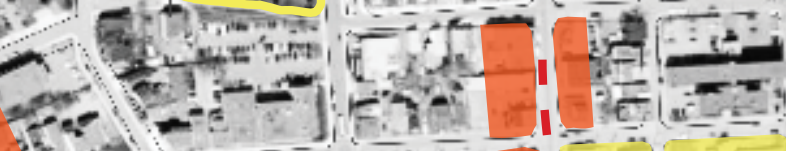

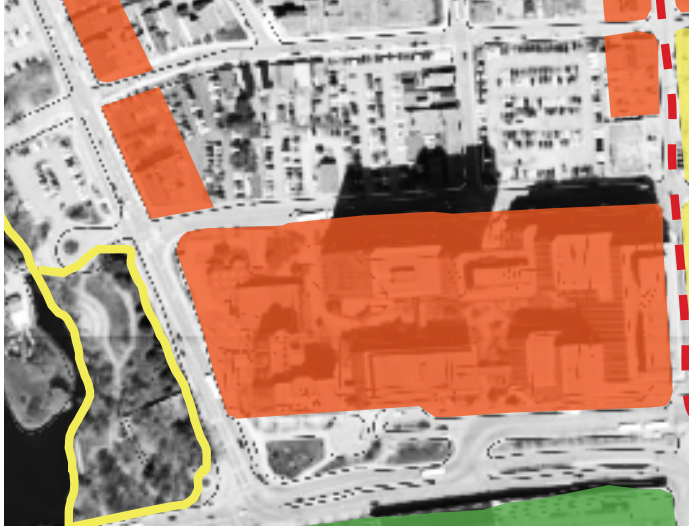

Night life

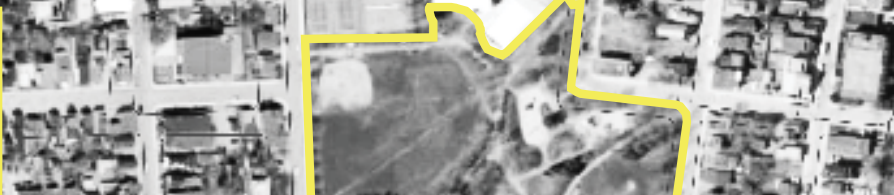

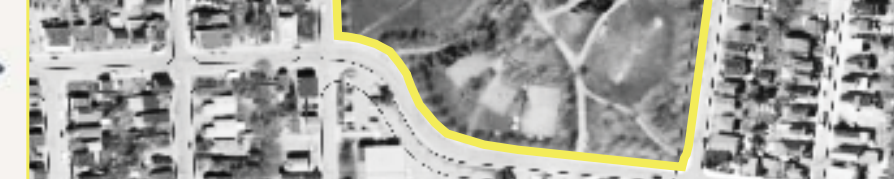

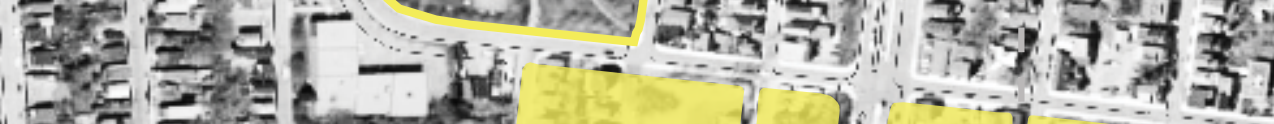

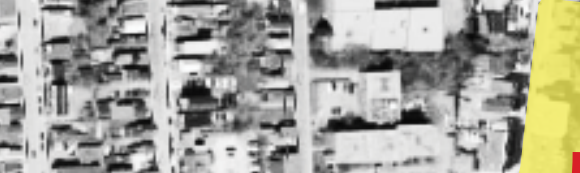
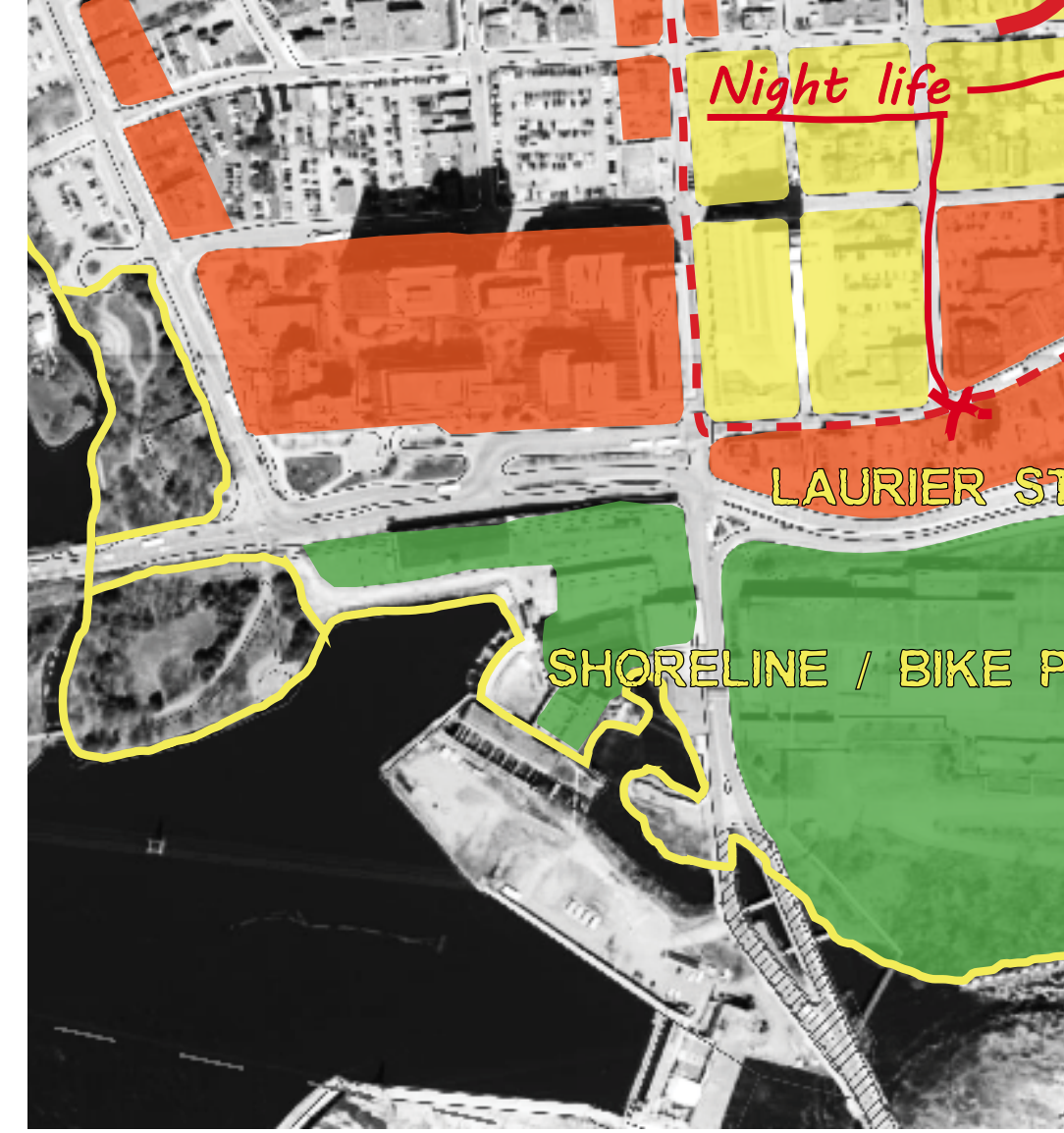

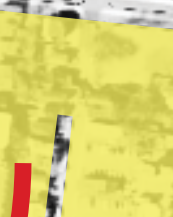

\section{OLD}

HULL
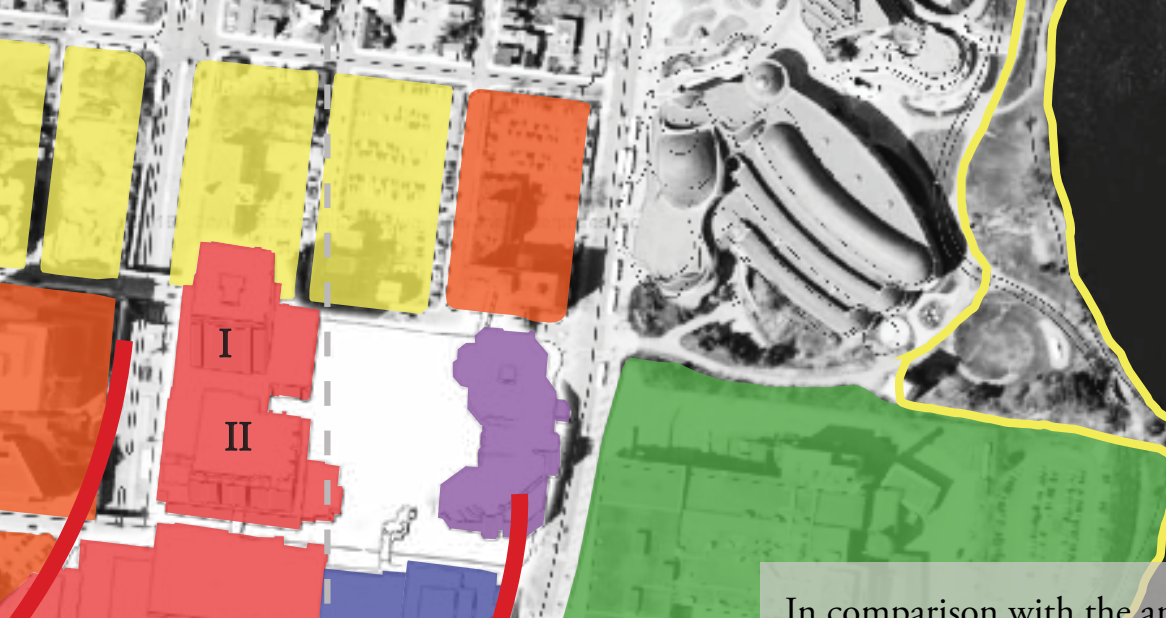

In comparison with the analysis delivered by Etienne Gaboury, the core demographics of Hull has not changed substantially over the past five decades. Interestingly, the industrial, governmental, commercial and residential areas are evolving by juxtaposition from the shore to the Old Hull triangle.

Many of the original industrial buildings continue to occupy the shores of the river with the Many of the original industrial buildings continue to occupy the shores of the river, with the
notable exception of the site reclaimed by the Museum of Canadian History located at the Portage bridge.

The neighborhood to the West side area of Place du Portage I \& II are comprised of mixed use office buildings. The area to the West of Portage IV extending beyond the Old Hull triangle is predominantly residential with a few businesses.

Laval street is more developed with bars, restaurants and businesses all along the Old Hull triangle. Promenade du Portage is commercial all along the street but mostly serves the working hours of government workers. The red dotted line indicates the locations where government employees go during lunch time. After office hours, only the Old Hull triangle shows signs of life at night with the presence of the locals. The occupation of the Portage buildings on such a large footprint does not allow the neigh bourhood to be osmotic with what is left of the shore accessible to the public. La majorité des habitants du Vieux-Hull ne sont que de passage dans la ville et sont que locataires to ville doit gérer avec un nombre considérable d'itinérants, ce qui rend certains coins de la ville moins fréquentables et fréquentés. 


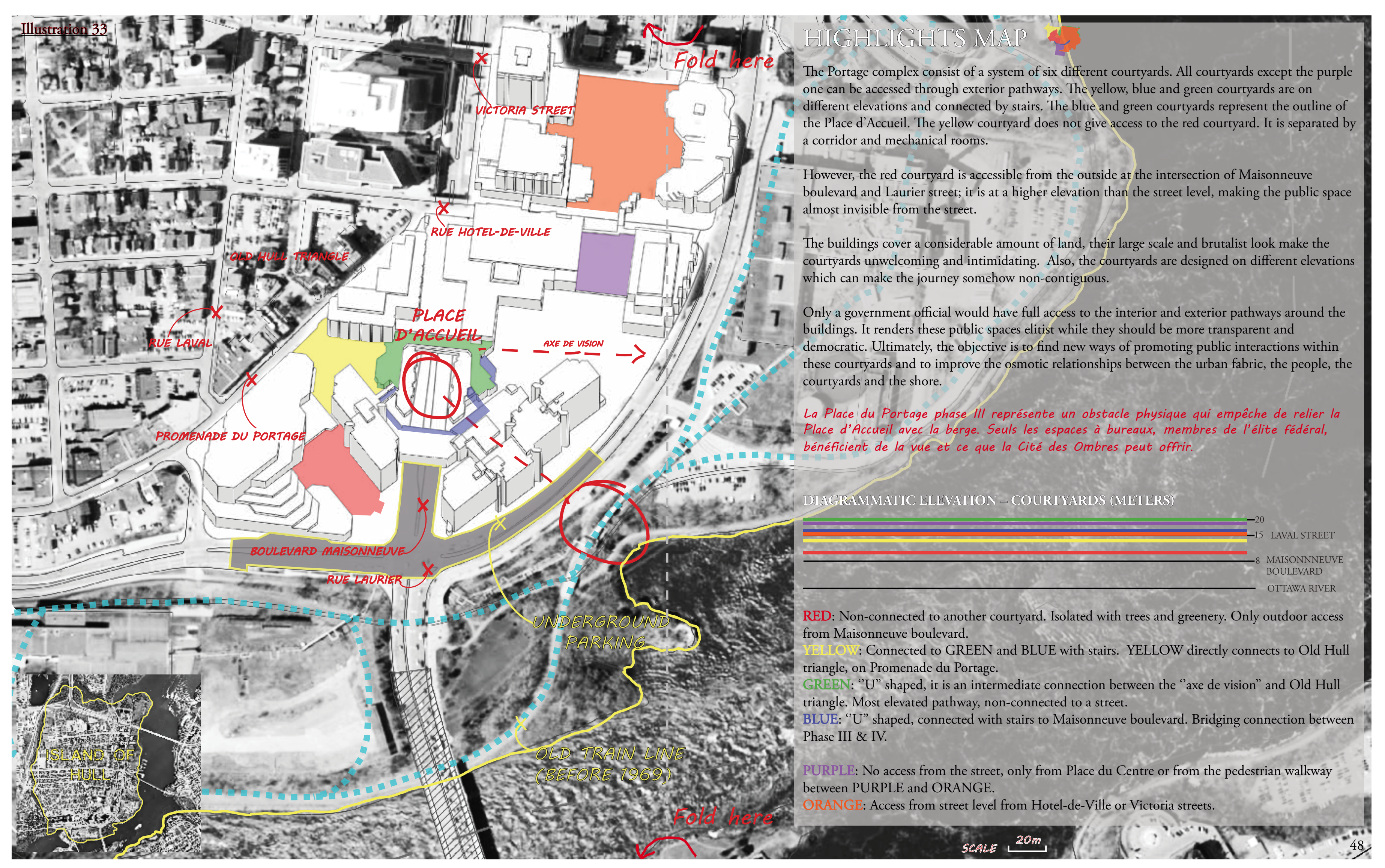


Illustrations $34 \mathrm{a}-\mathrm{f}$
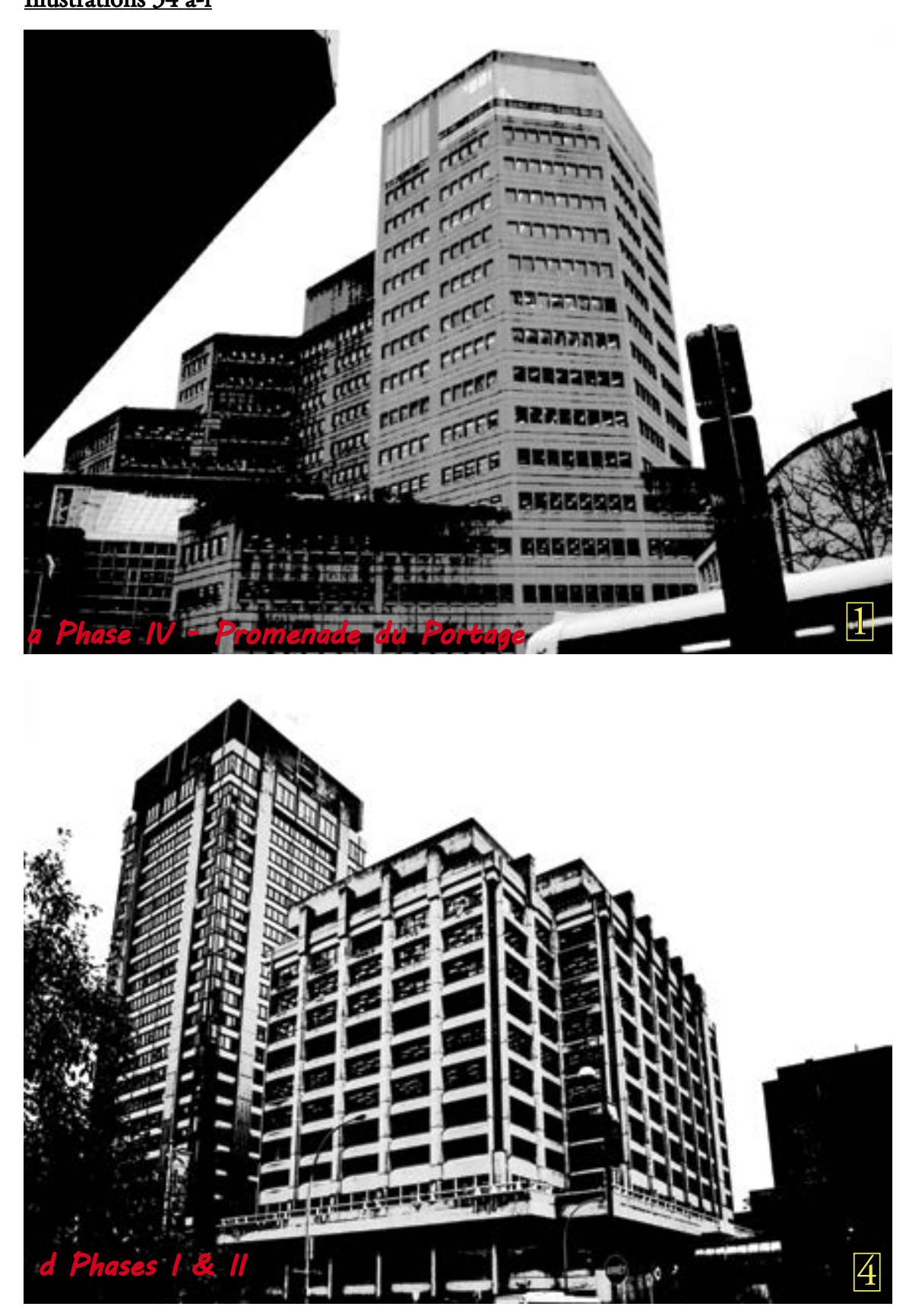
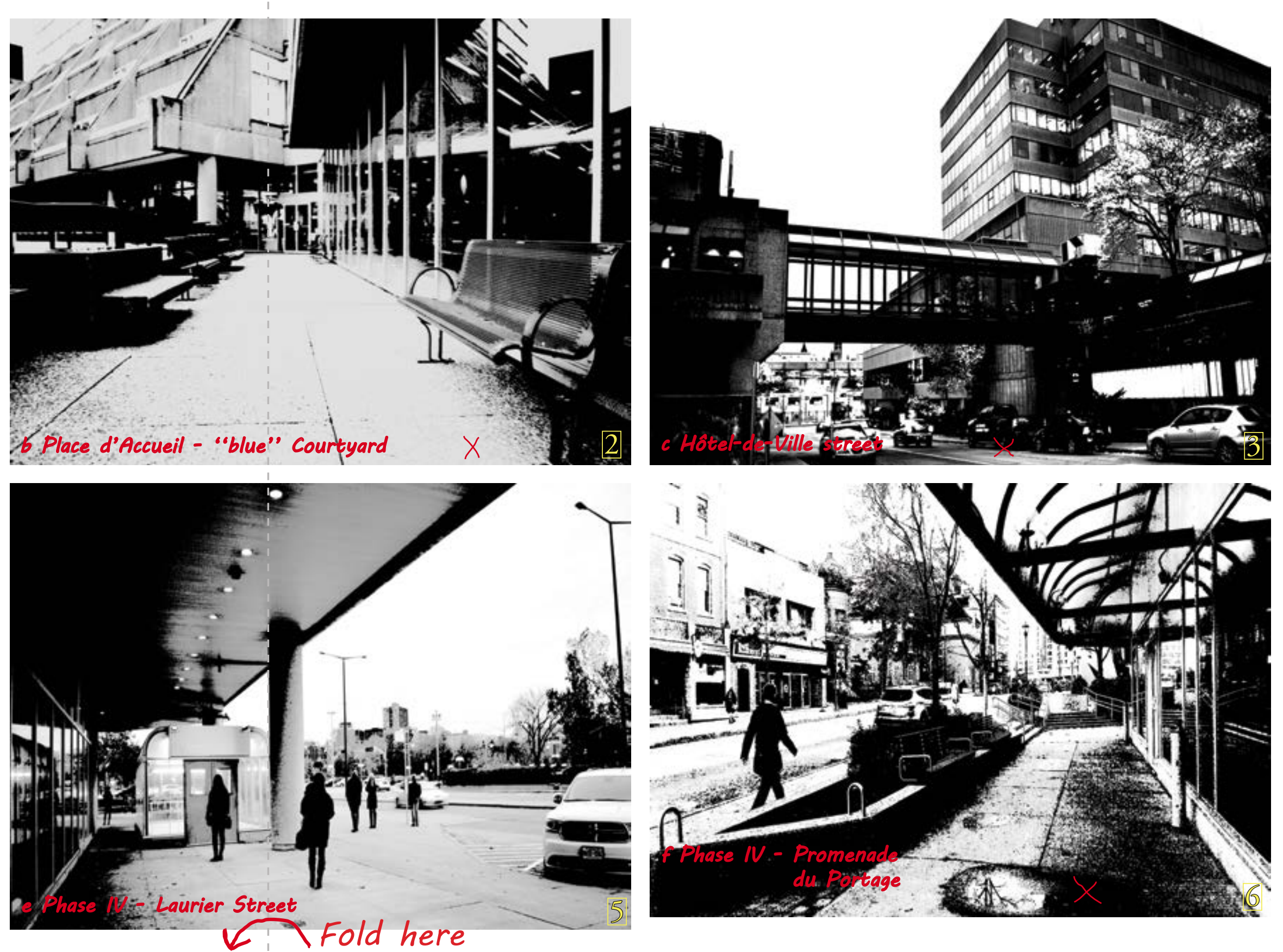
SITE PHOTOS
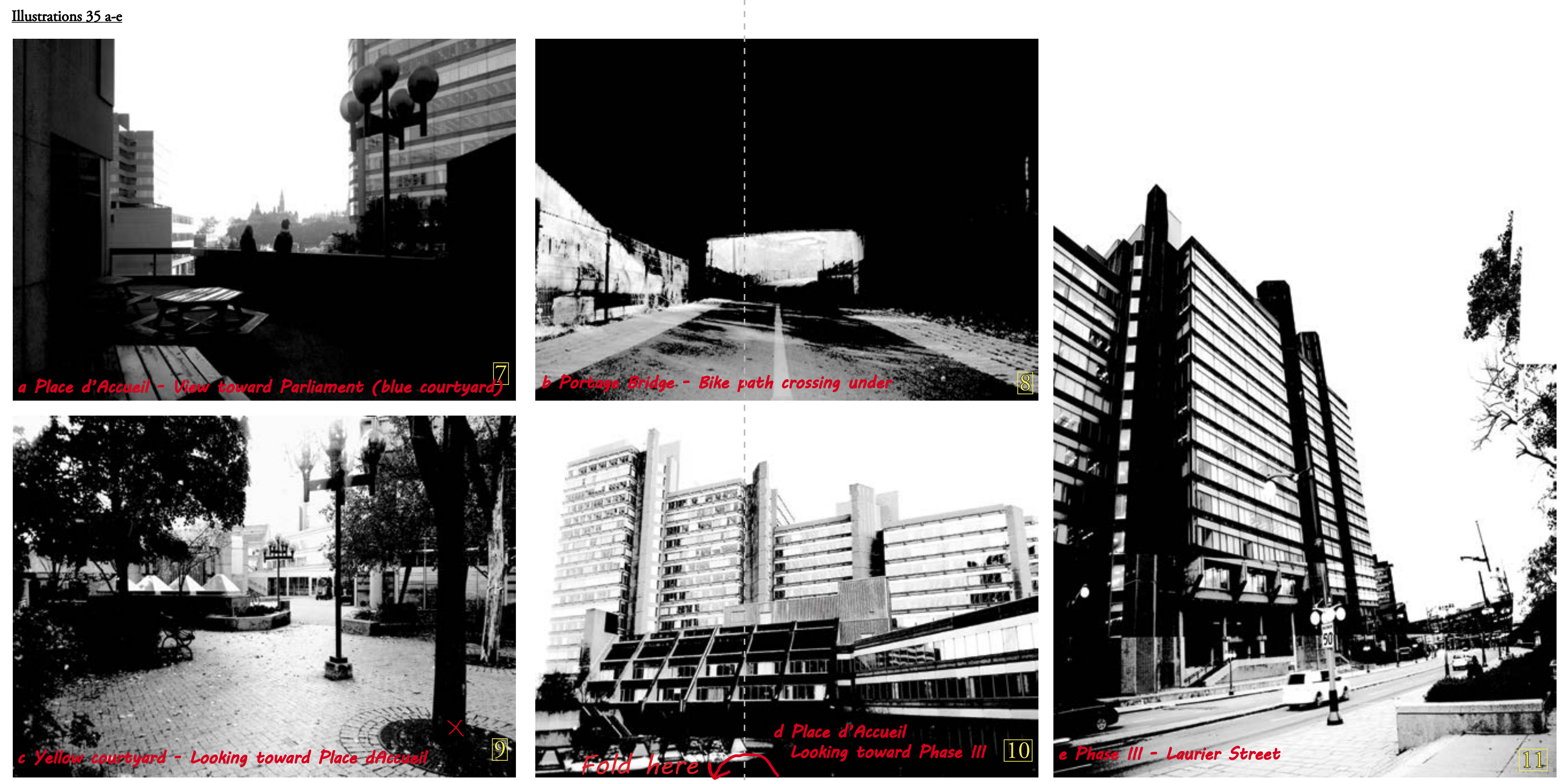


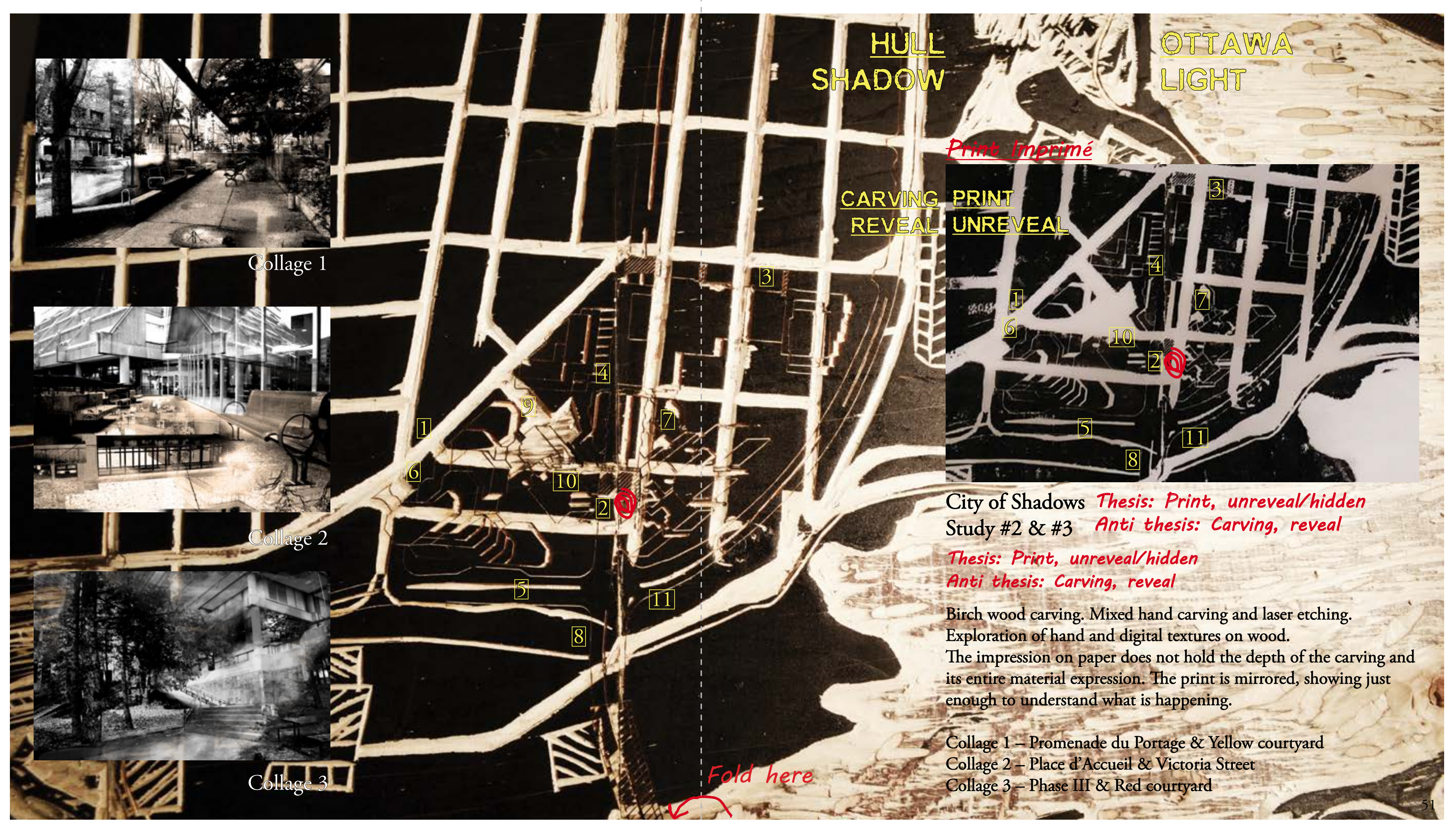


City of Shadows

Study \#3

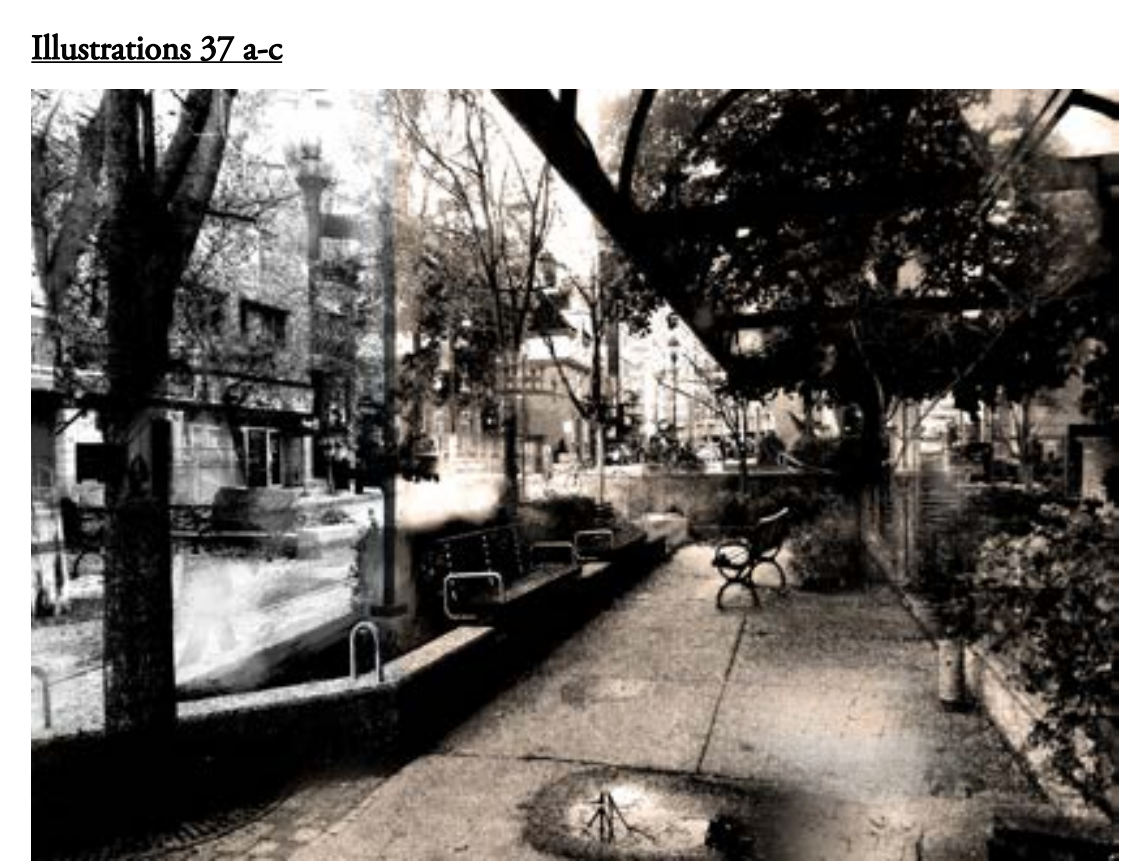

Collage 1 Promenade du Portage \& Yellow courtyard

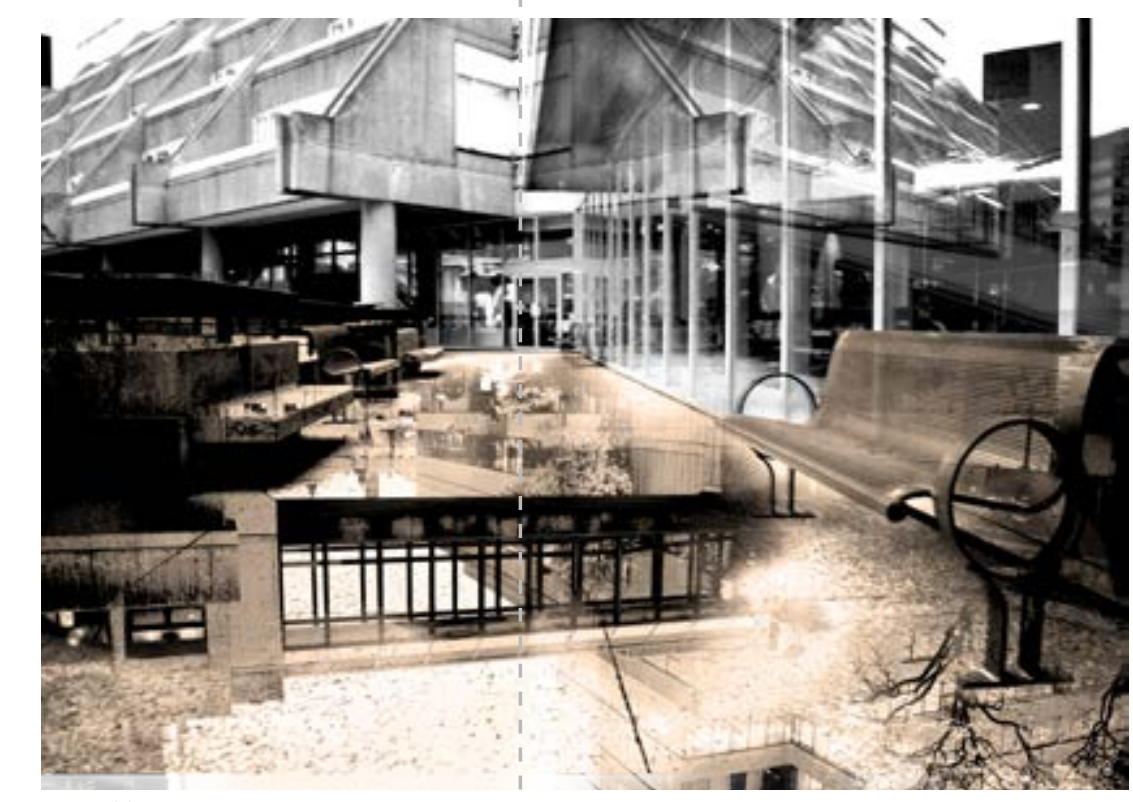

Collage 2 Place d'Accueil \& Victoria Street

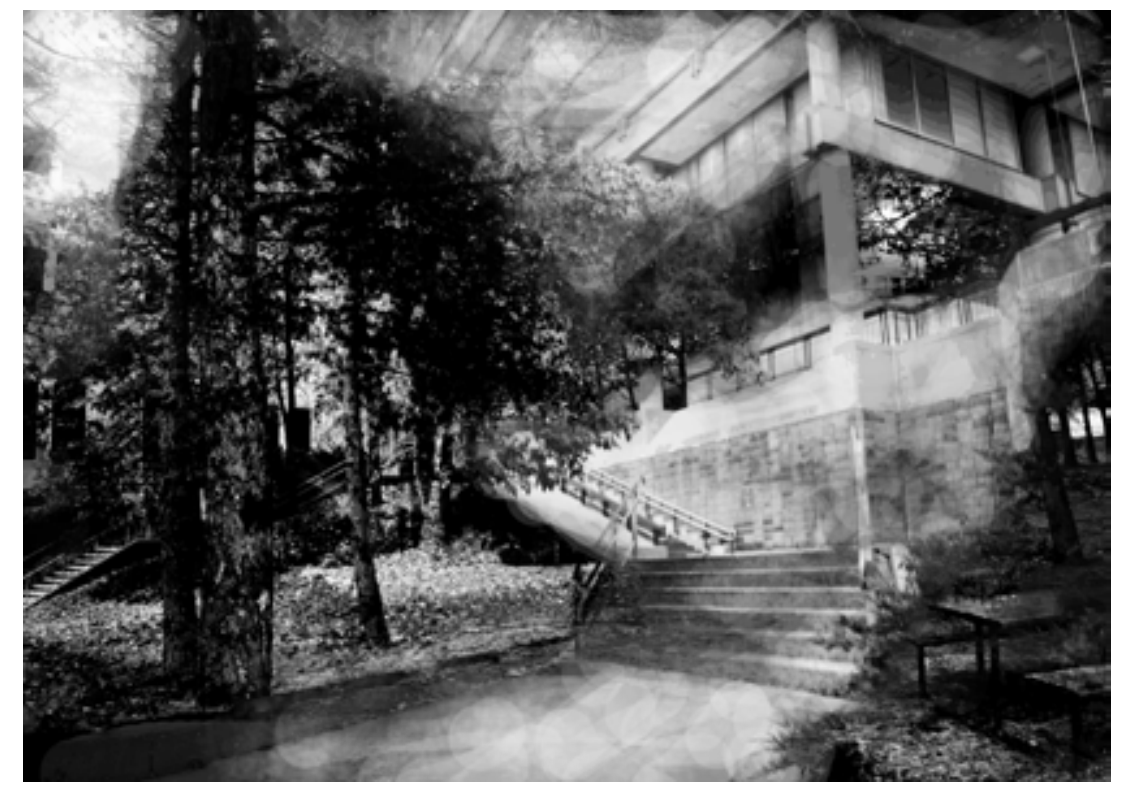

Collage 3 Phase III \& Red courtyard

Study \#3 is an exercise about the possibility of merging existing elements on site to improve the space quality within the courtyards. Using at a higher potential what already exists.

Fold here

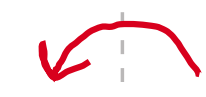




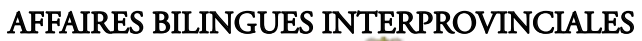 \\ Québec 哭}

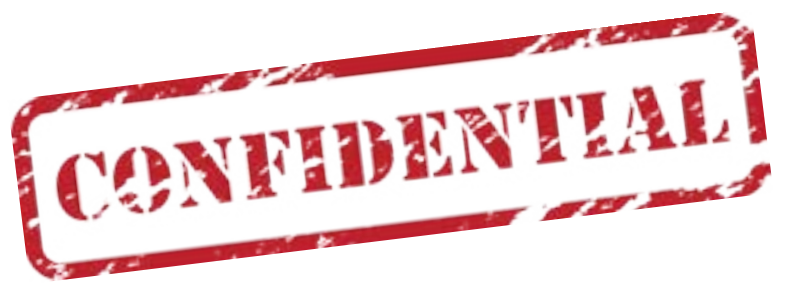

\section{THE FLIPBOOK - PLACE D’ACCUEIL}

With the abandonment of rapid transit during the construction of the Portage buildings, the circulation through the Place d'Accueil is left stagnant. Government officials occasionally use the "Blue" and "Green" courtyards to pass from Phase III to Phase IV. Directly below, the public bus transportation offers transit on Maisonneuve boulevard during week days.

The Place d'Accueil is meant to present more than a concrete platform overlooking the Portage bridge. It was intended to be a core of circulation between the underground, the street levels, the intermediate courtyards, the buildings and the surrounding neighborhood. Most importantly, it was designed to radiate from its circularity to reach the shoreline.

Le parcours actuel qu'emprunte la Place d'Accueil n'est qu'ennuyant. Il ne fait pas honneur auxconvictions de Gaboury, responsable de sa création. À quoi bon sélectionner un architecte à l'extérieur du Québec et de l'Ontario si on $n$ 'applique pas un tant soit peu l'essence de son concept.

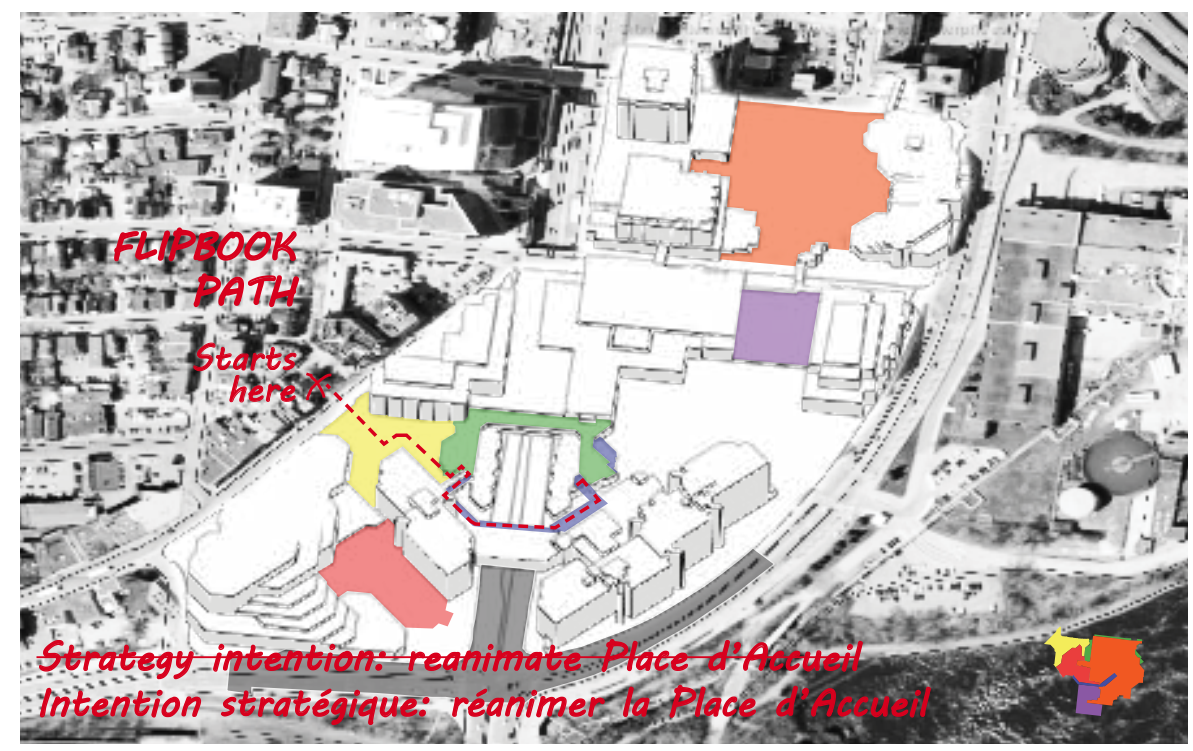



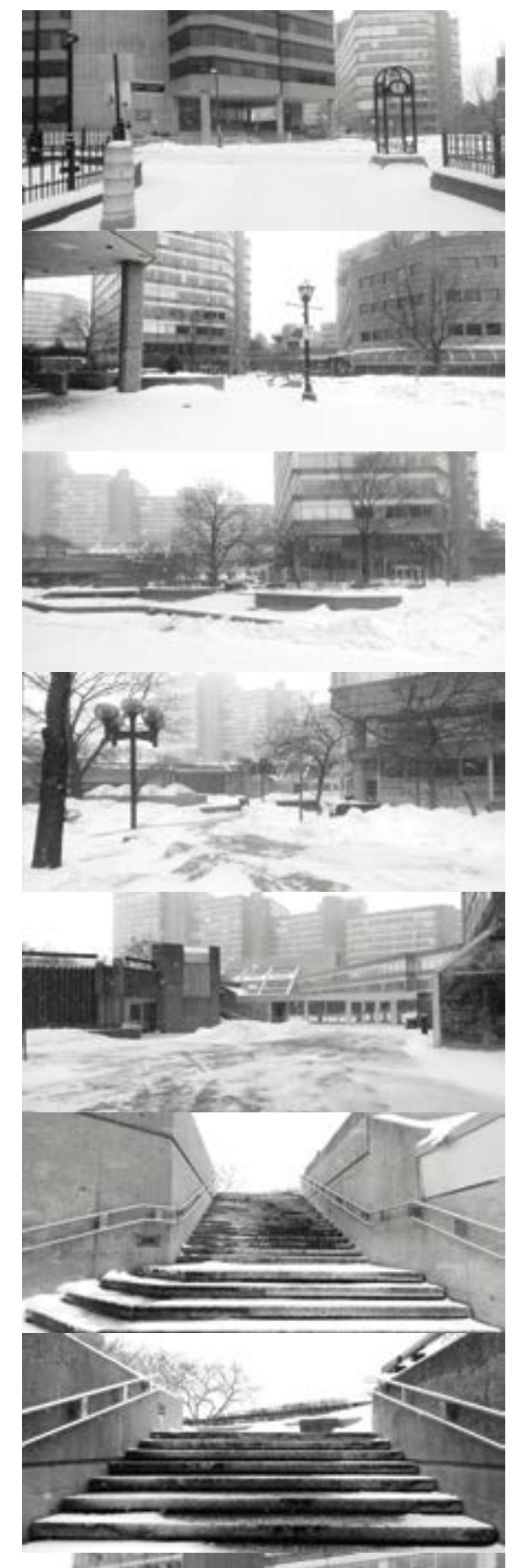

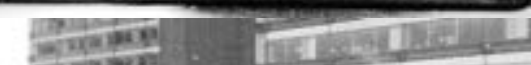
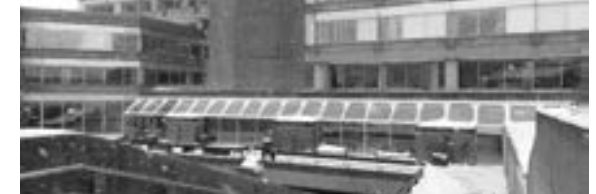

Absence humaine
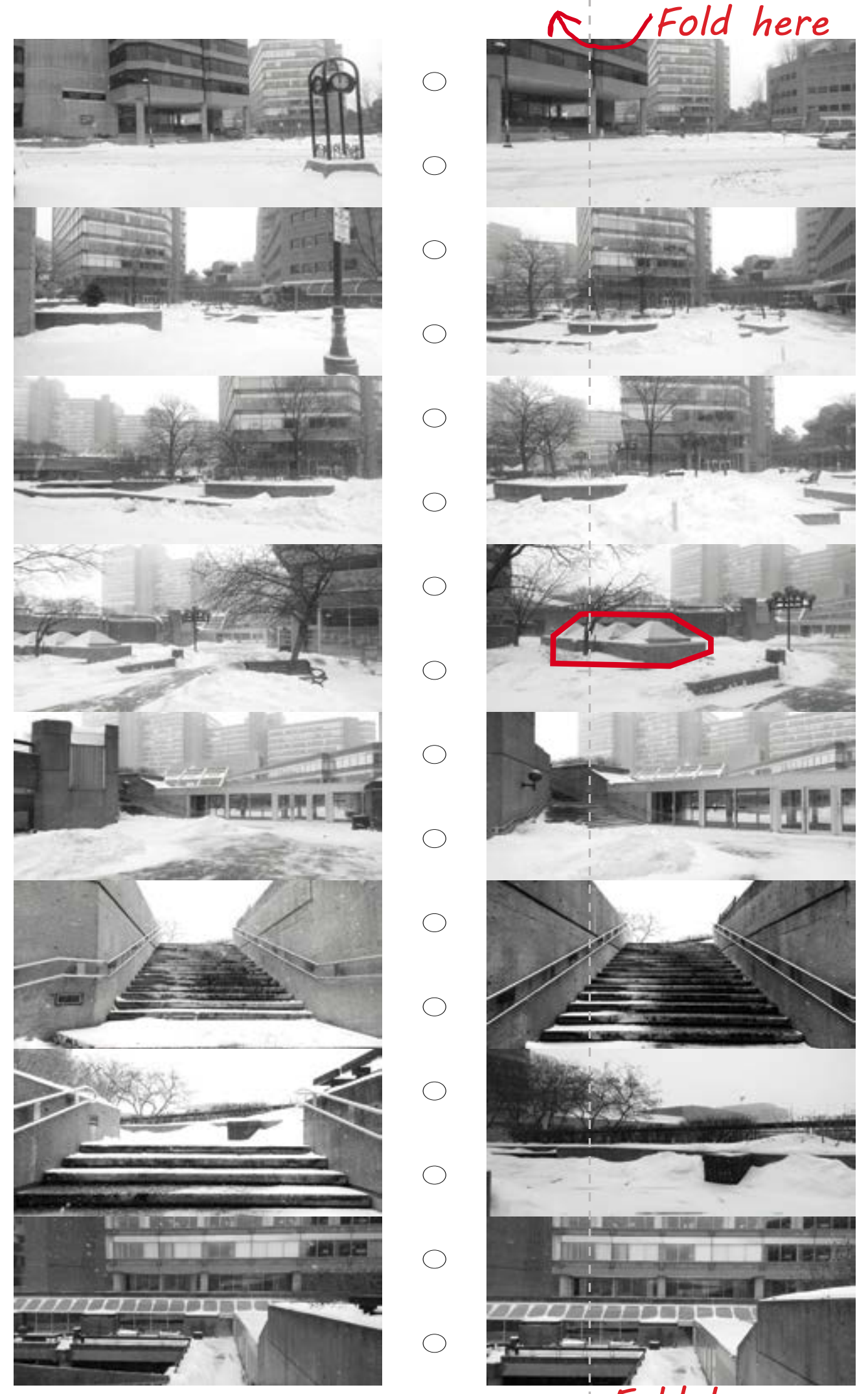
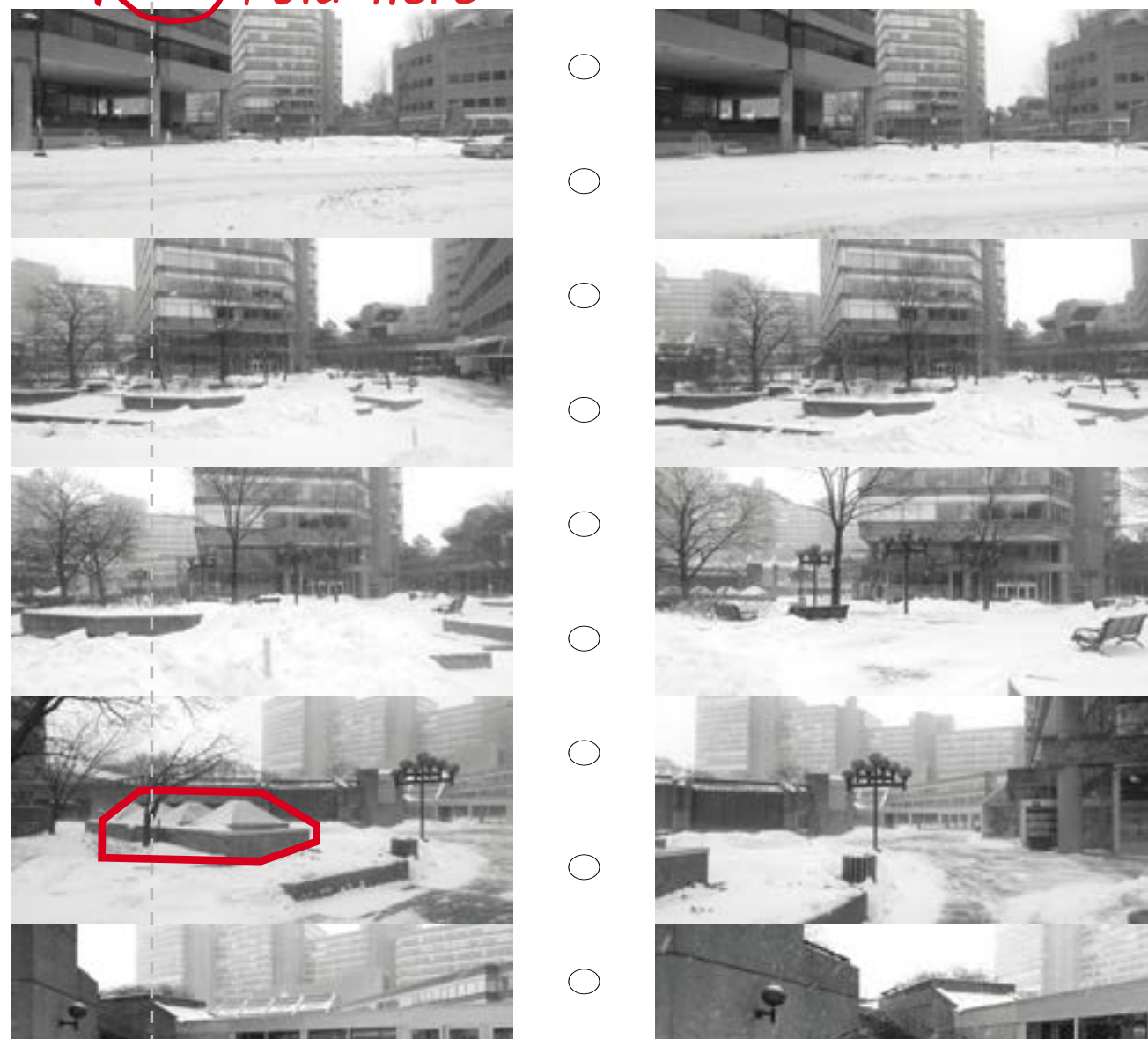

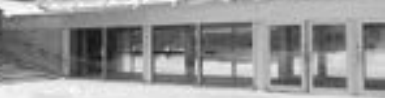

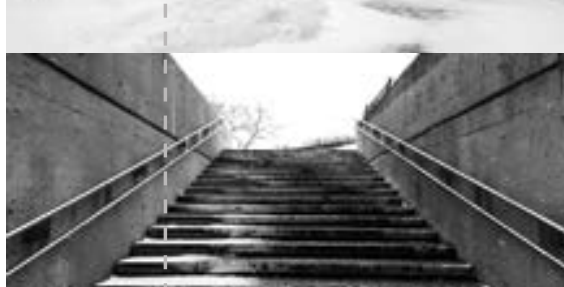

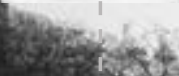

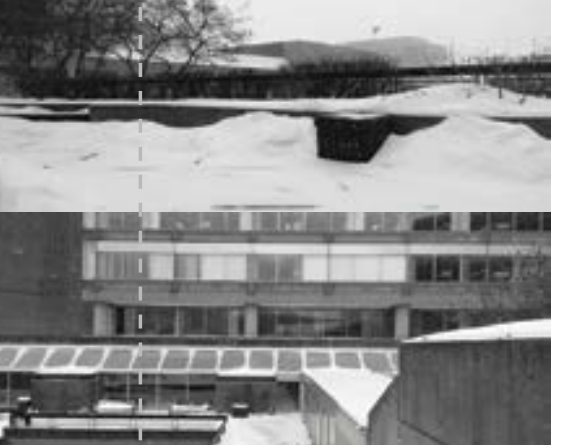

$-\quad-1=-1$

Fold here
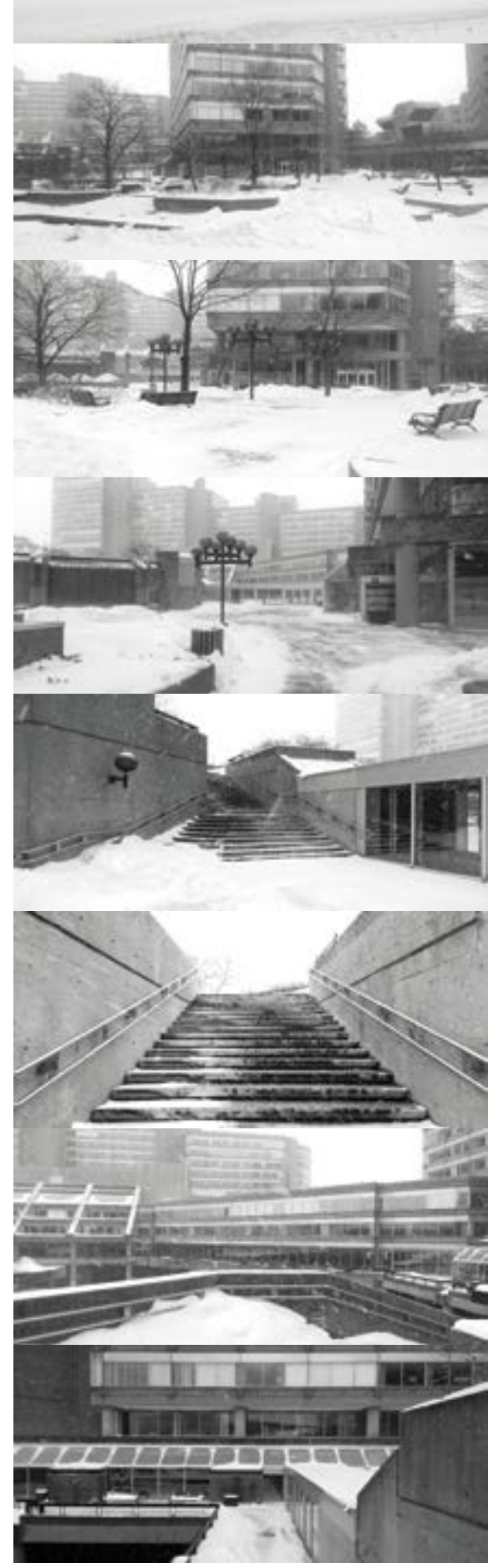

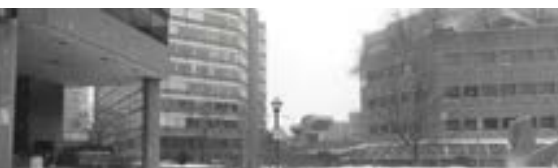

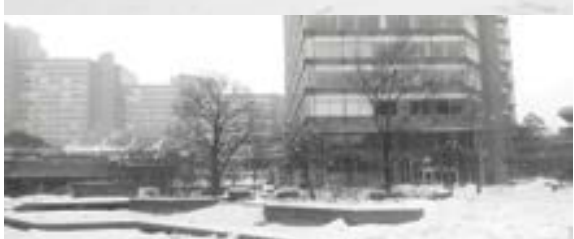

$\sqrt{2} 4^{49}$
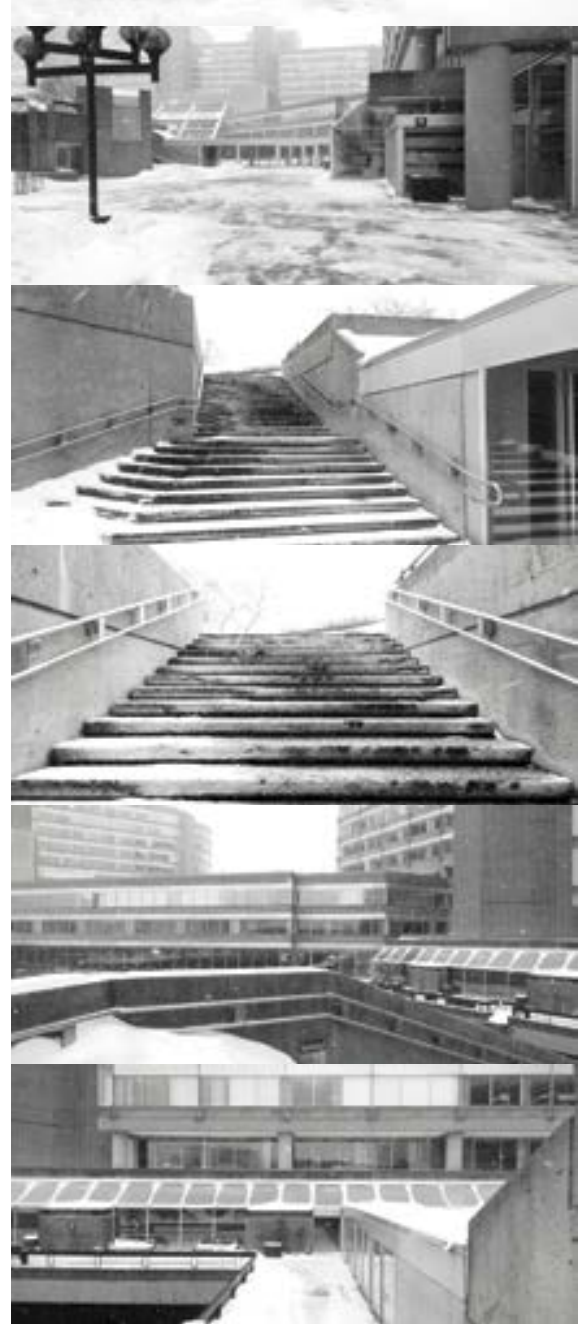

Pictures 1 to 40 - F1 

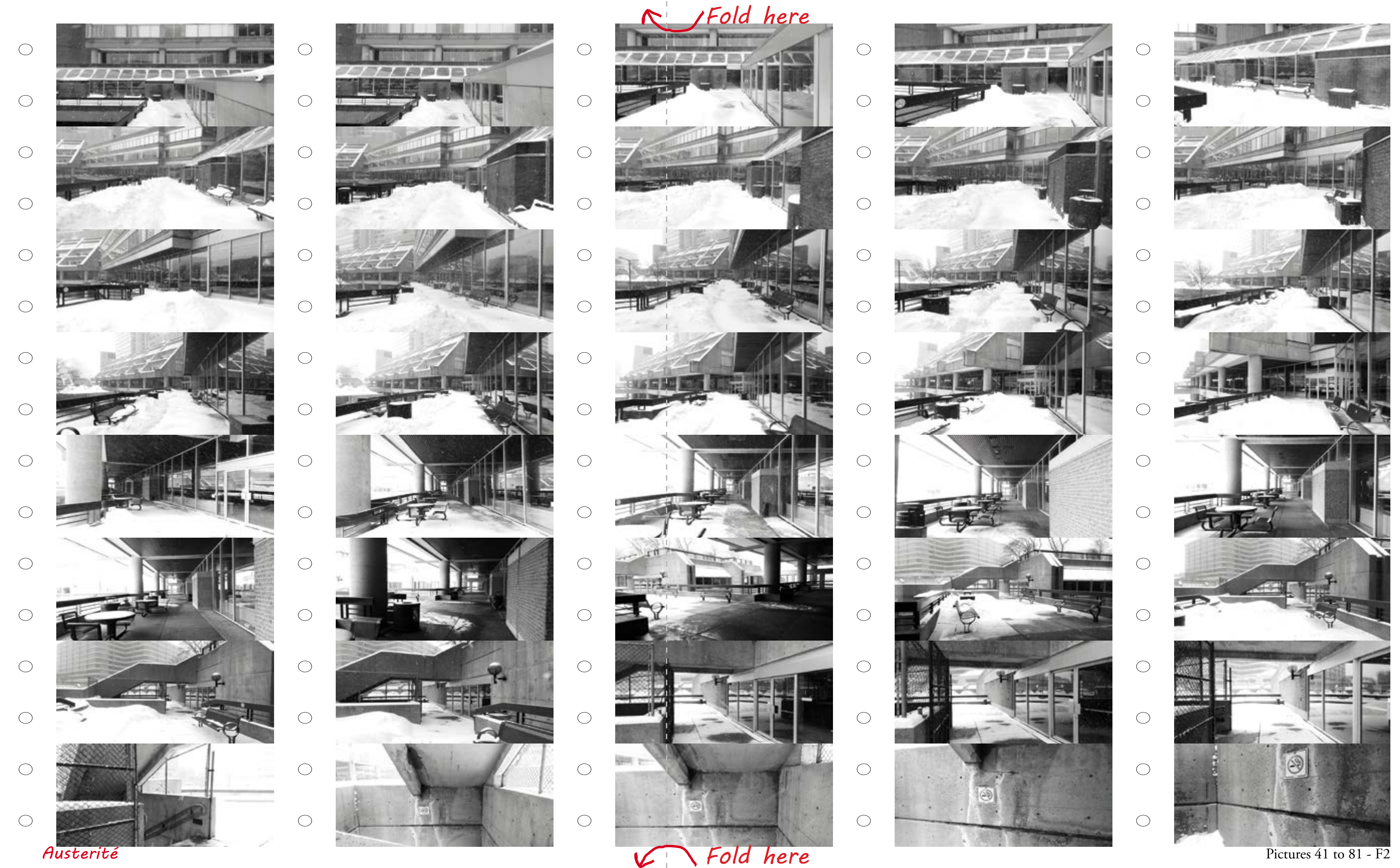

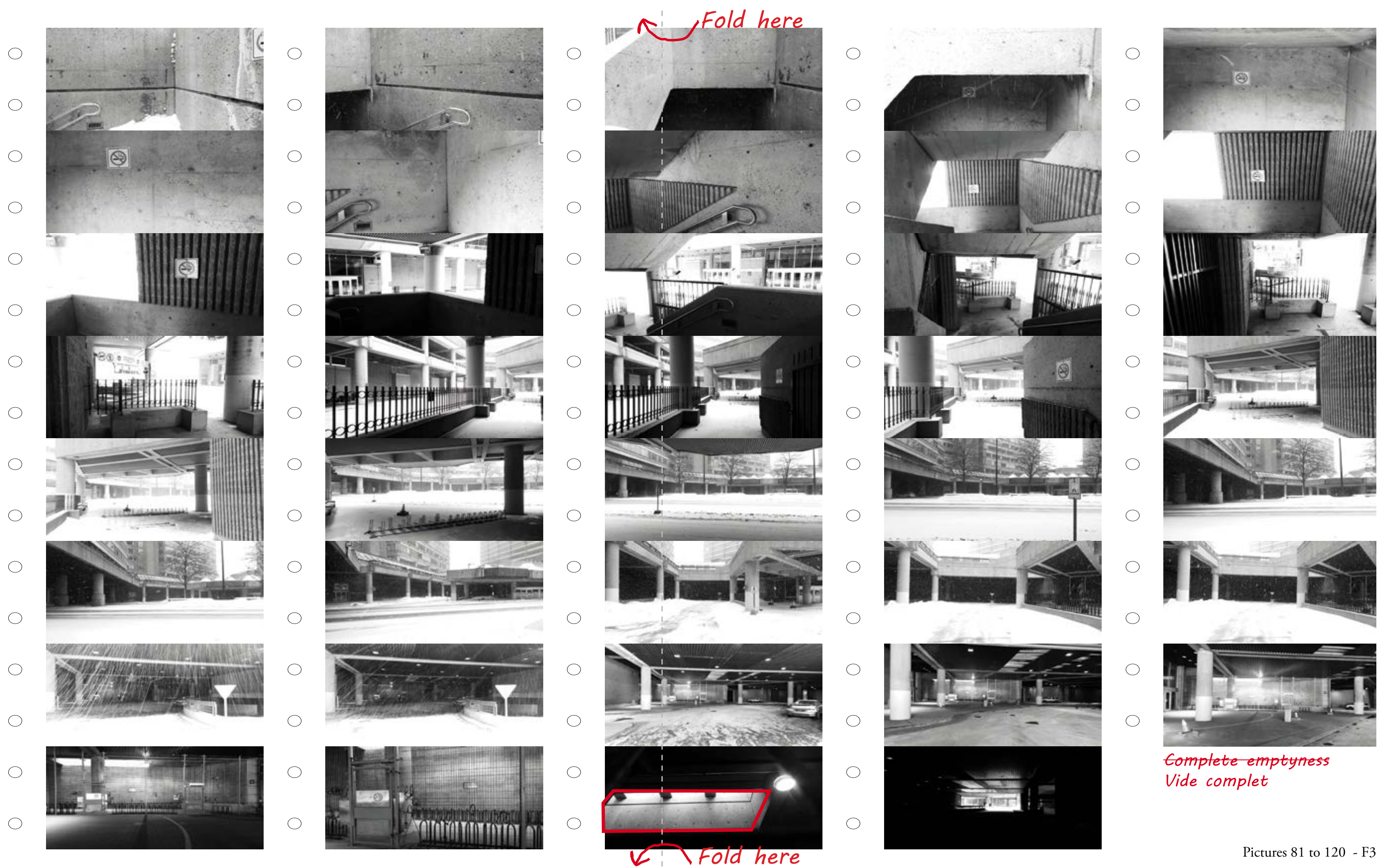
Vide complet 


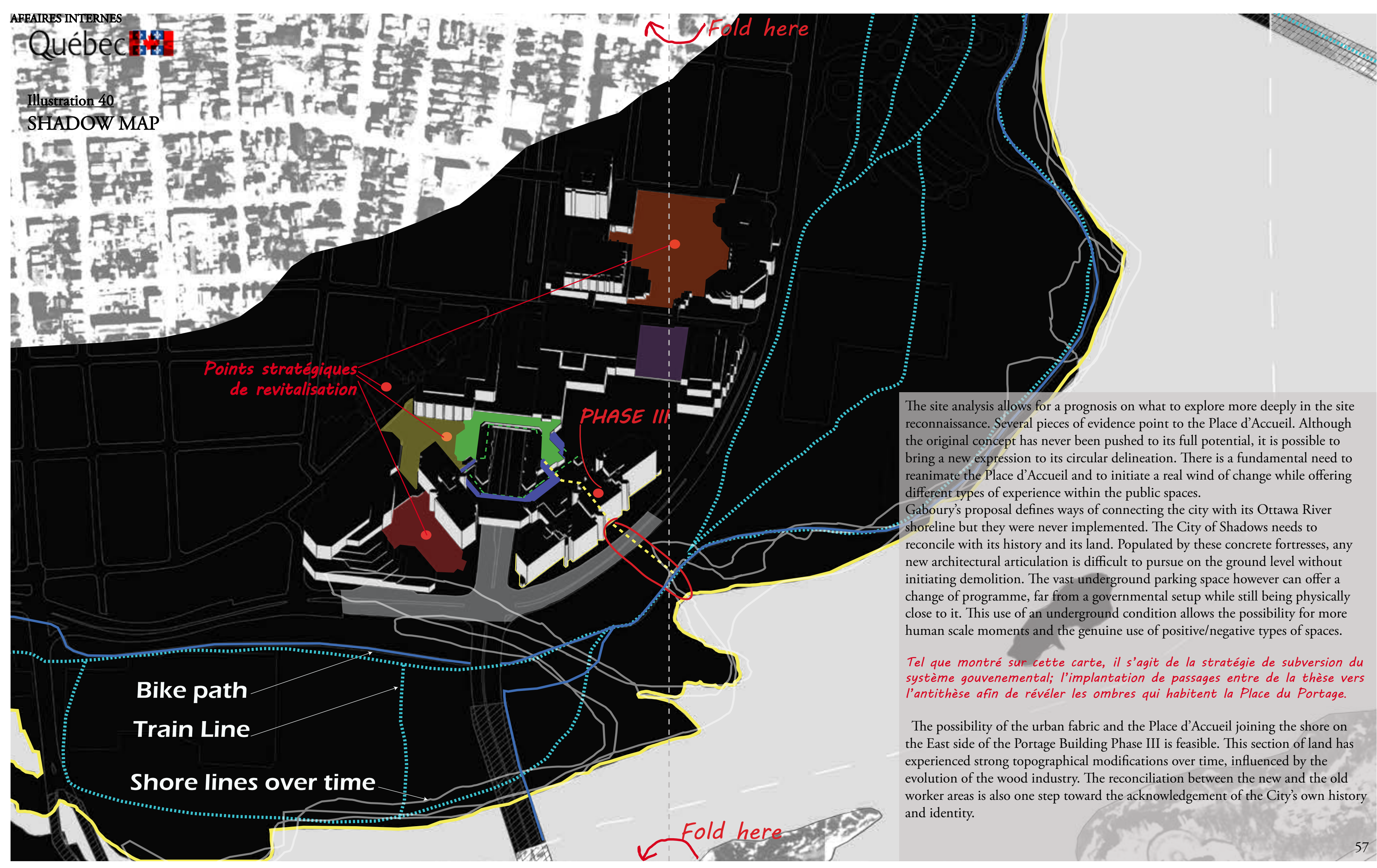




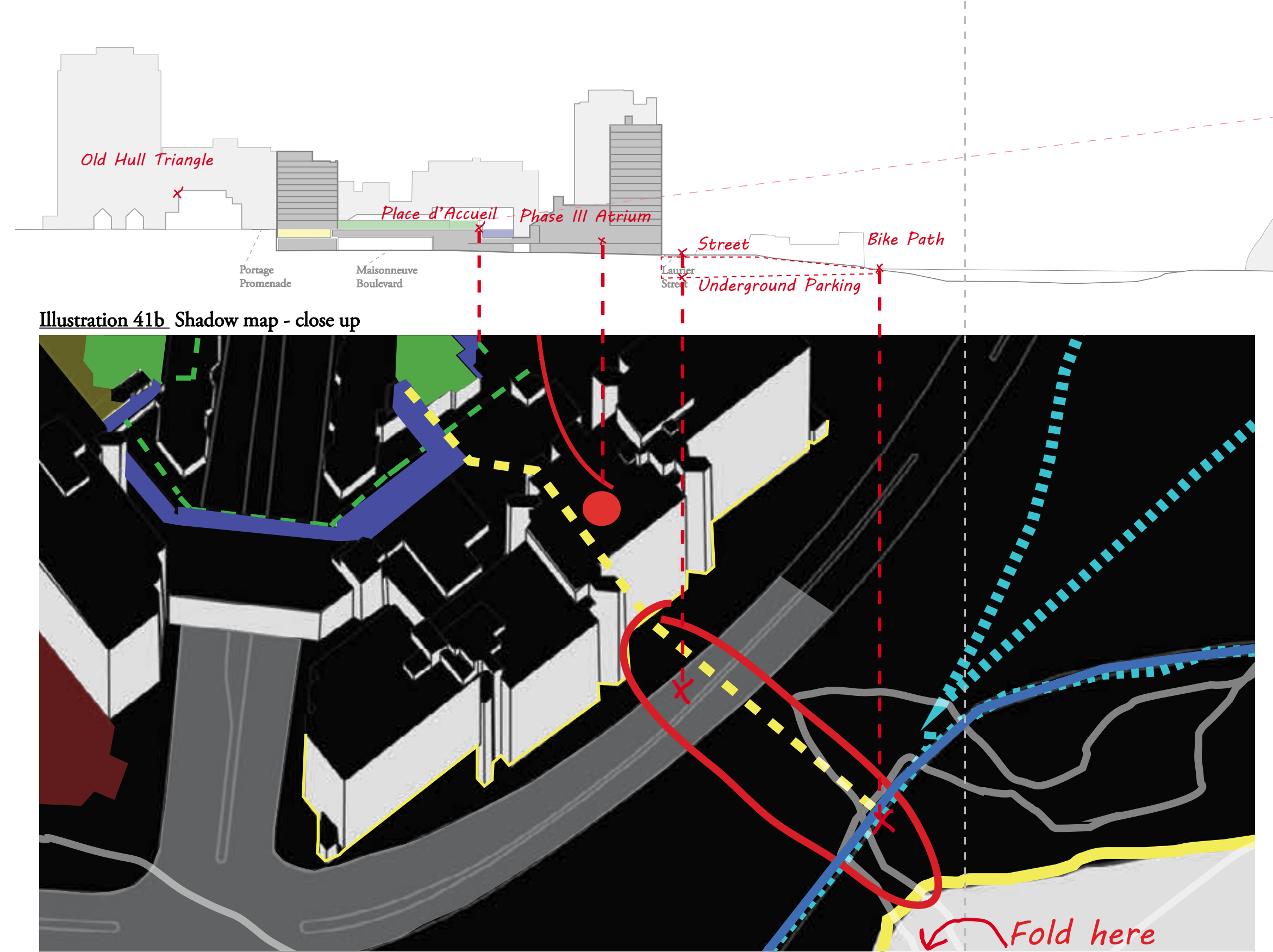

This section shows the "axe de vision" between the Place d'Accueil and the Parliament. On different layers are the residential, industrial and governmental areas. The high-rise architecture disrupts the low-rise dwellings and factories. The monumentality of the buildings and the multiplicity of the working spaces amplify the banality of the government bureaucrats' daily routine. Also, the different elevations of the courtyards make the circulation confusing and discouraging.

Certain sequences of moments need to happen underground in order to disturb this banality. Hence the introduction of a positive-negative concept, borrowed from printmaking, in support of this interruption and contrast. 
THE CITY OF SHADOWS

STUDY \#4 COLLAGE-CARVING

Illustrations 42 a-e
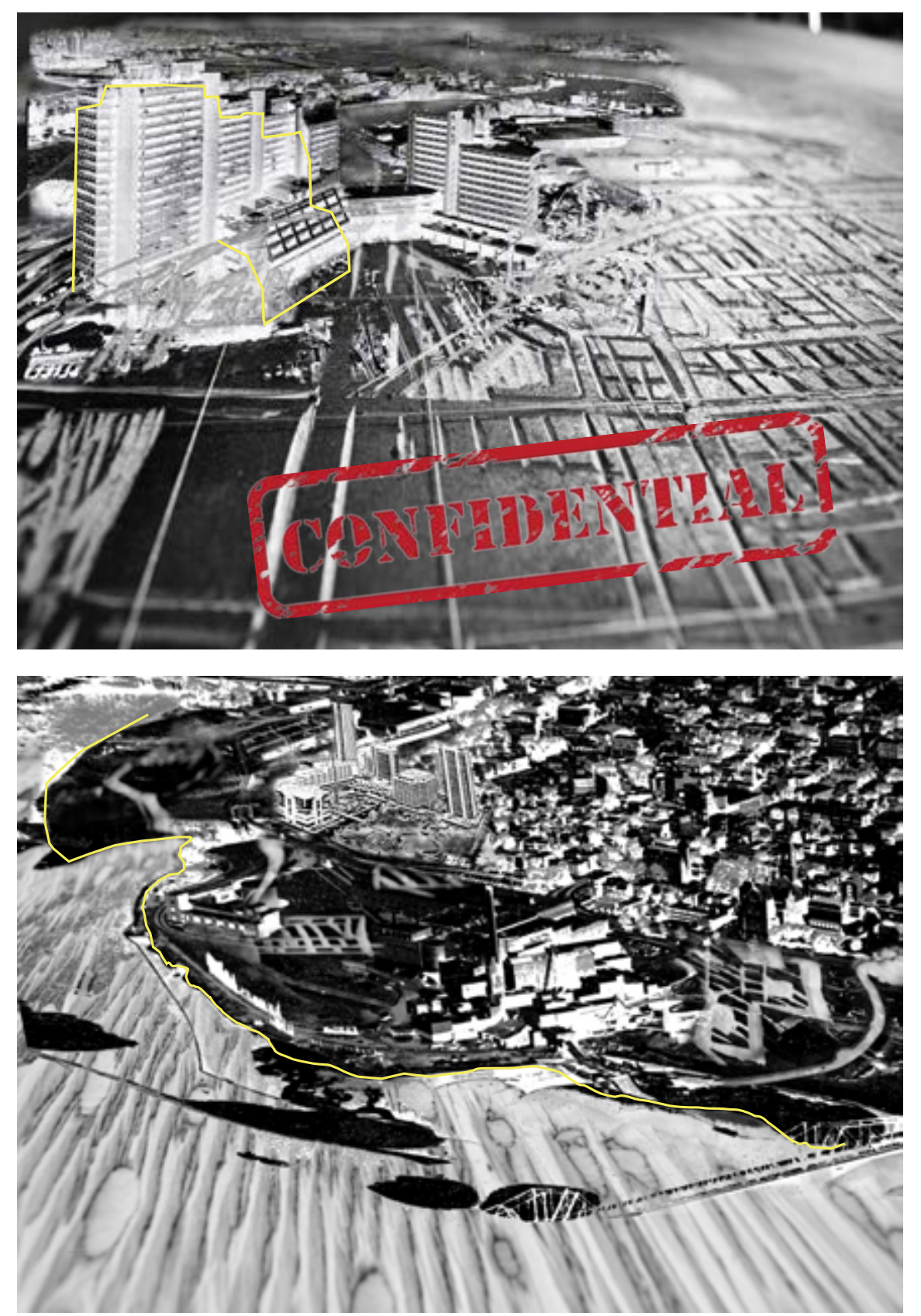

This sequence of collages represents different negotiations between the current conditions of the Portage buildings and printmaking.
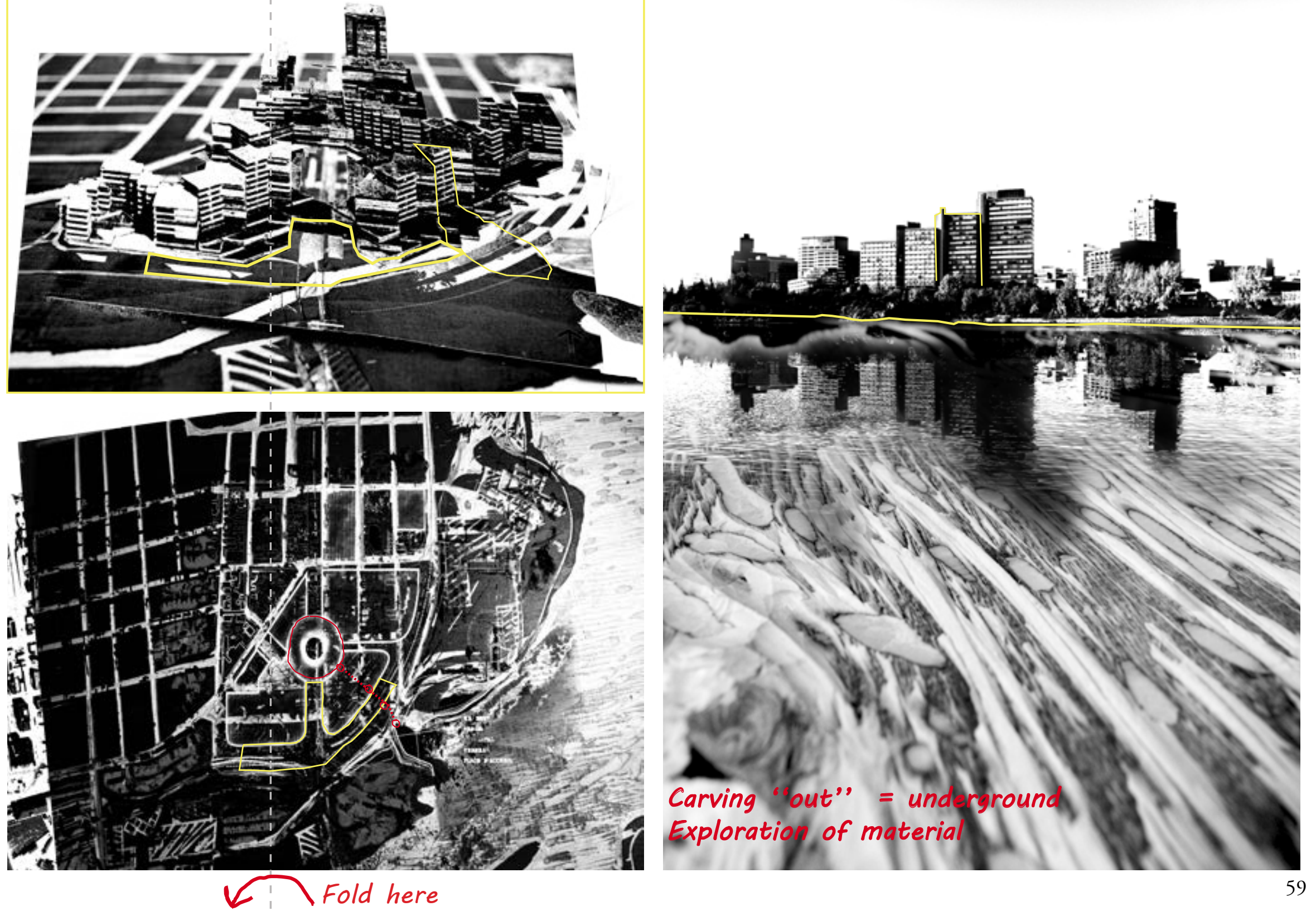
AFFAIRES INTERNES

Québec 缹

\section{THE CITY OF SHADOWS}

STUDY \#5 : Shadow study "Black market"

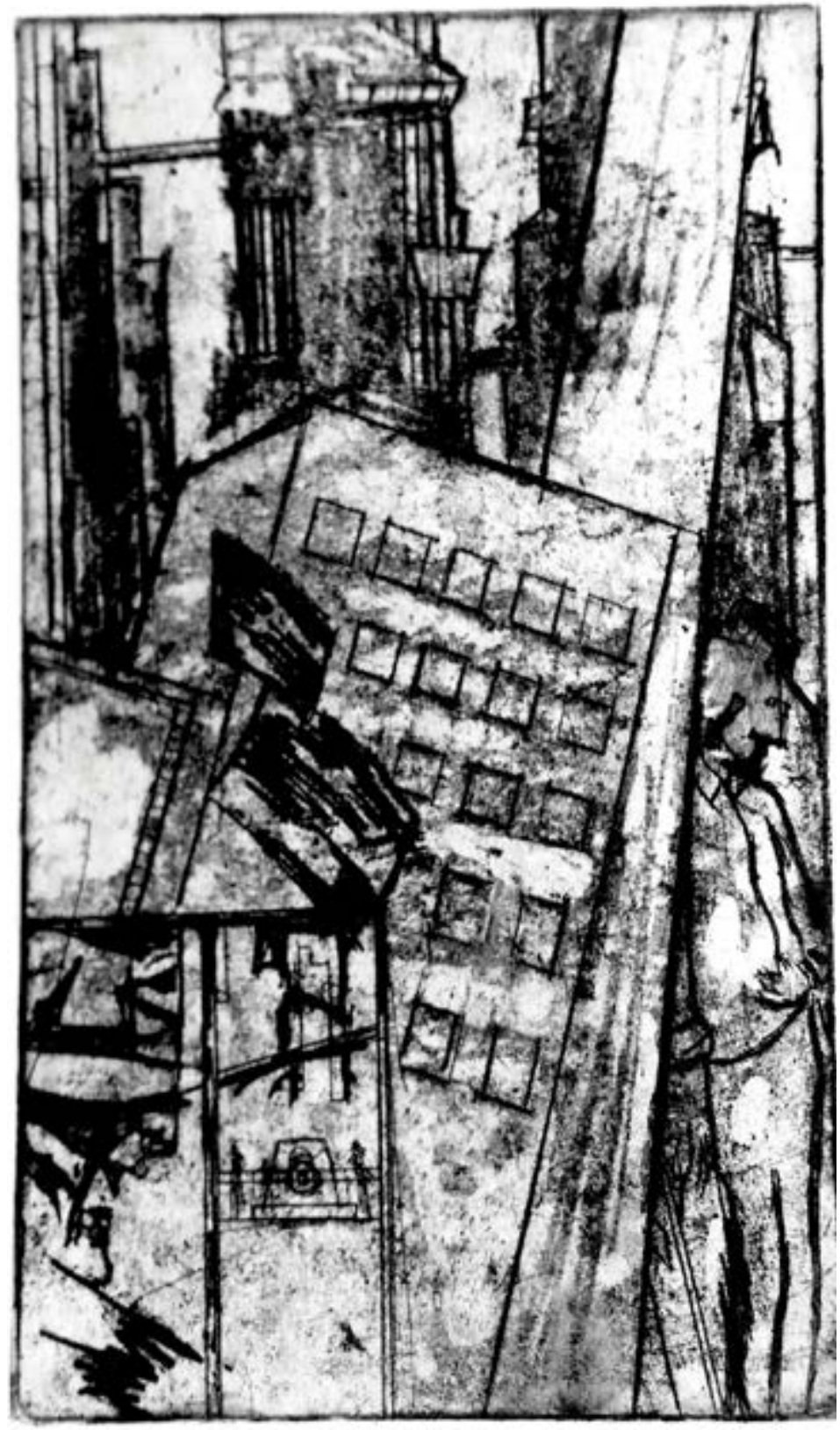

Illustration 43 Zinc etching, black ink on BFK paper 
AFFAIRES INTERNES

Québec 渴

\section{THE CITY OF SHADOWS}

STUDY \#6 : Shadow study of Phase III

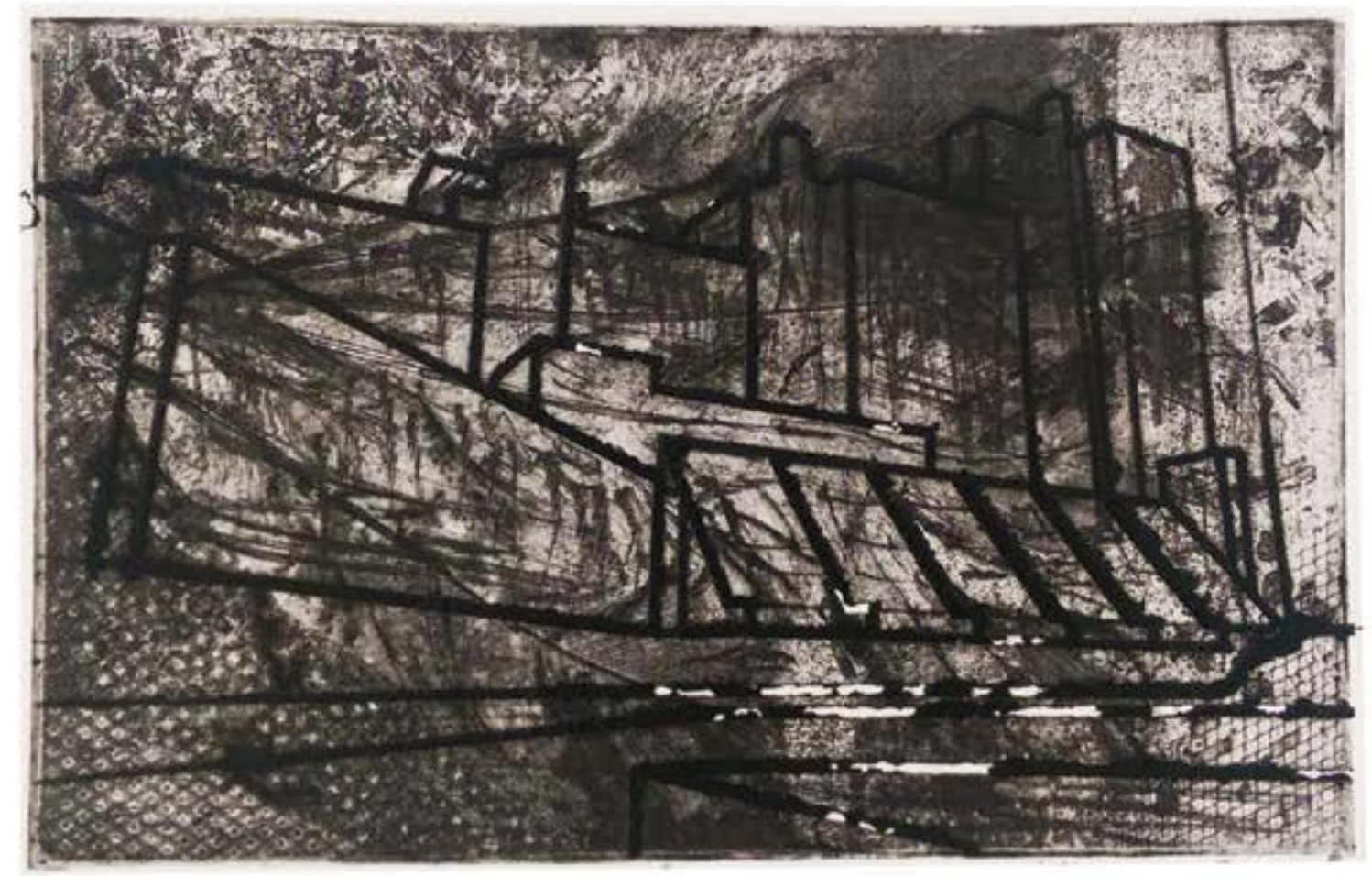

Illustration 44 Zinc etching, black ink on BFK paper

Study on etching plates with mixed hand \& digital techniques. 
AFFAIRES INTERNES

Québec 溲

\section{THE CITY OF SHADOWS}

STUDY \#7 Shadow reflections

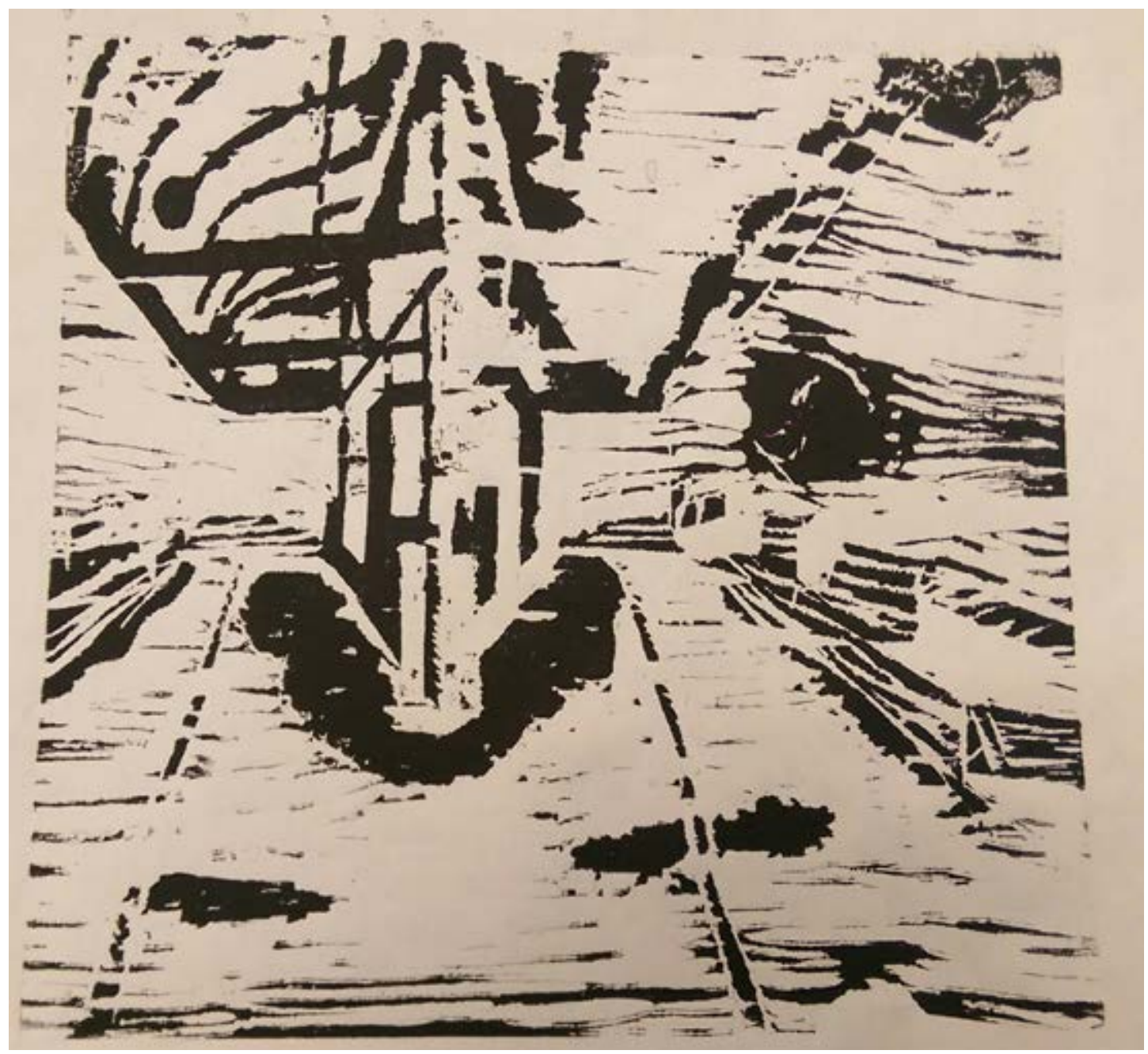

Ilustration 45 Woodcut, black ink on newspaper

Shadow study inspired from Collage \#1 
AFFAIRES INTERNES

Québec 溲

\section{THE CITY OF SHADOWS}

\section{STUDY \#8 Shadow foundation}

As per Confidentiality Agreement clause 44b this evidence cannot be shown to private consultant.

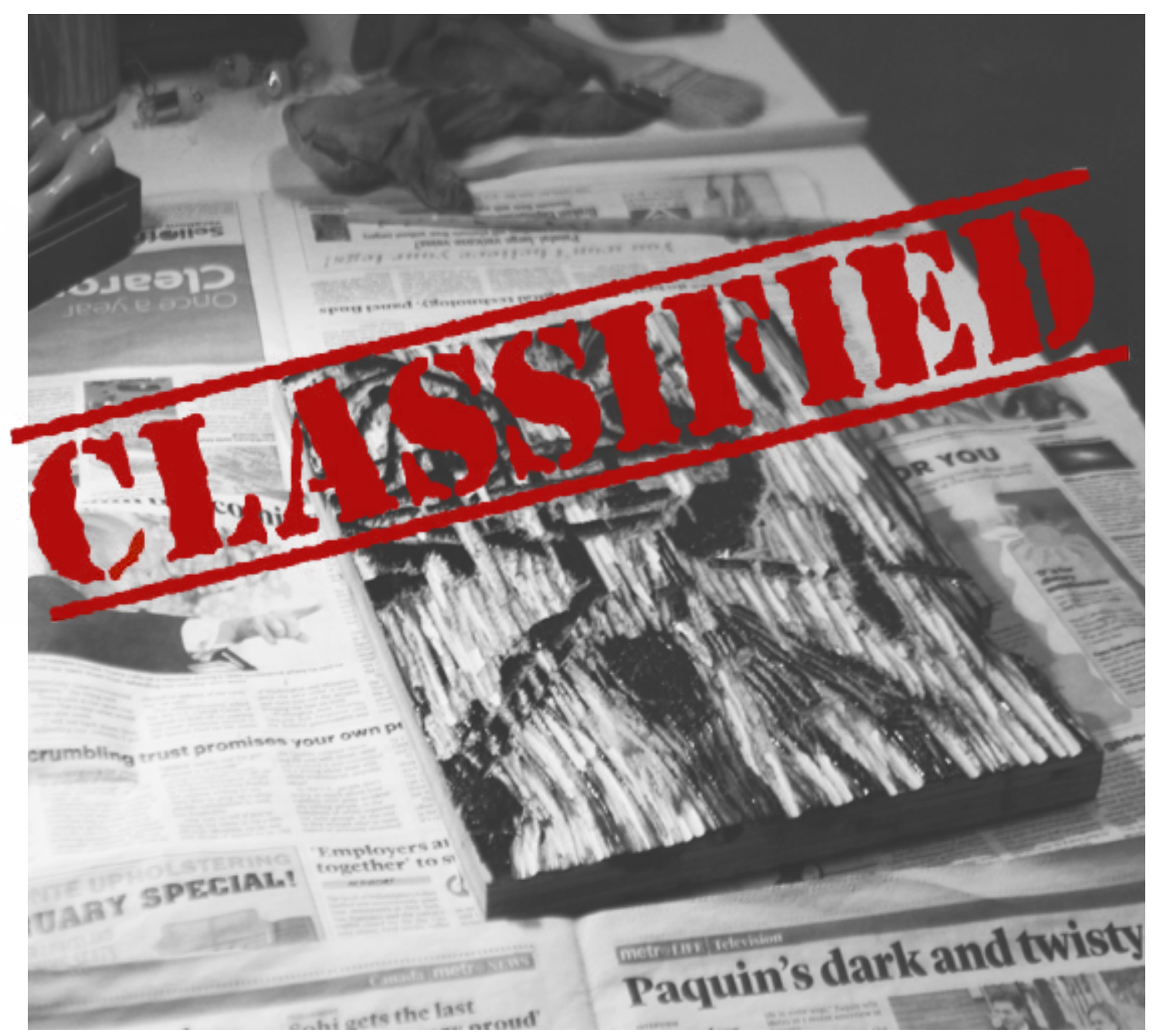

Hlustration 46 Woodeut, reduction technique, ink on rice paper

Shadow study inspired from Collage \#2 \& \#3 


\section{THE CITY OF SHADOWS}

\section{STUDY \#9 : MASSING MODEL}

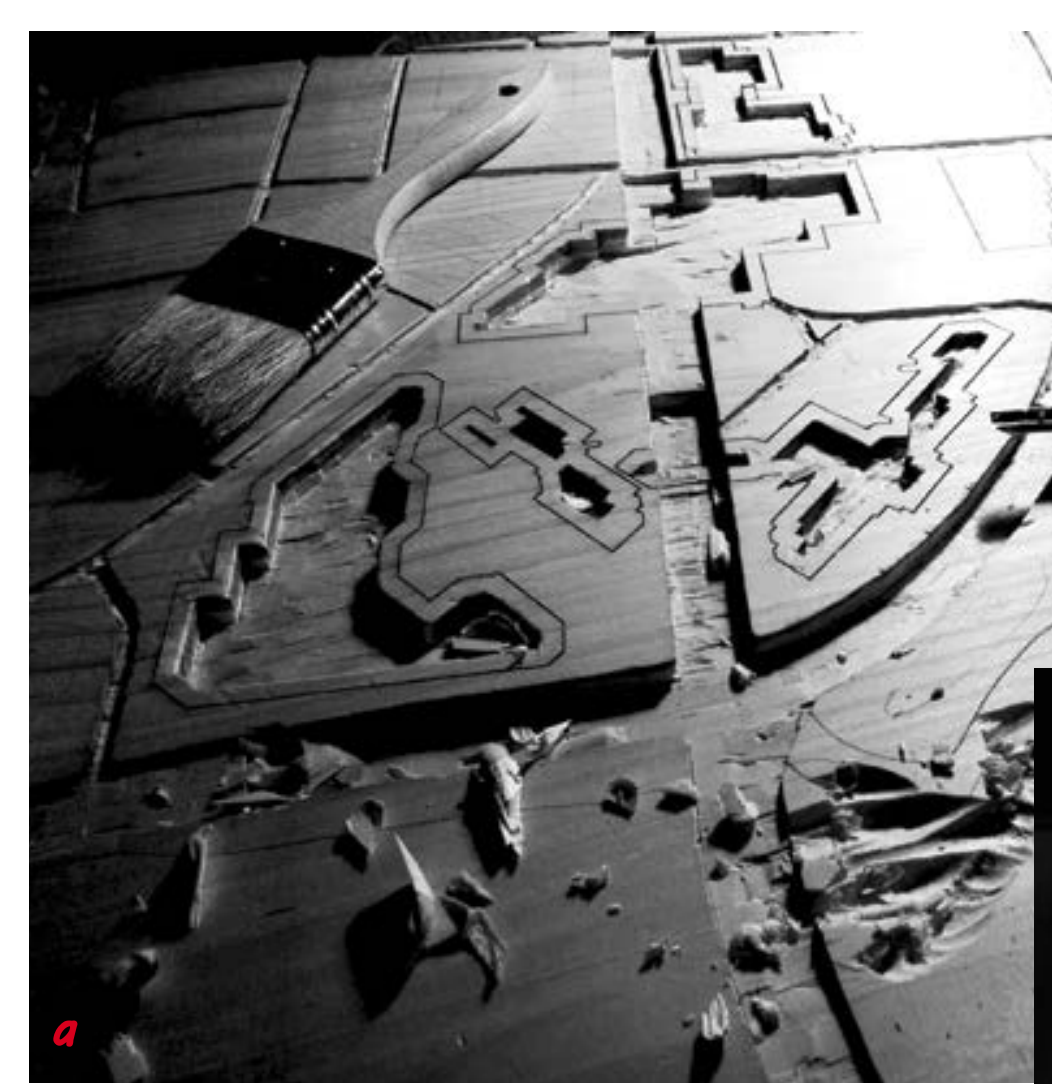

Ilustrations 47 a,b,c 18 "x24" pine block

The carving serves as a massing model but can also be printed.

a Mixed use of hand carving and digital etching. Emphasis on grid and interruptions, where the hand technique meets with the laser etching. Hand carving focuses on topography and undergroud massing.

b Use of hollow acrylic as a paradoxical way to express the heaviness of the federal and provincial buildings at the heart of the city. Only the topography of the focused site was Only the top

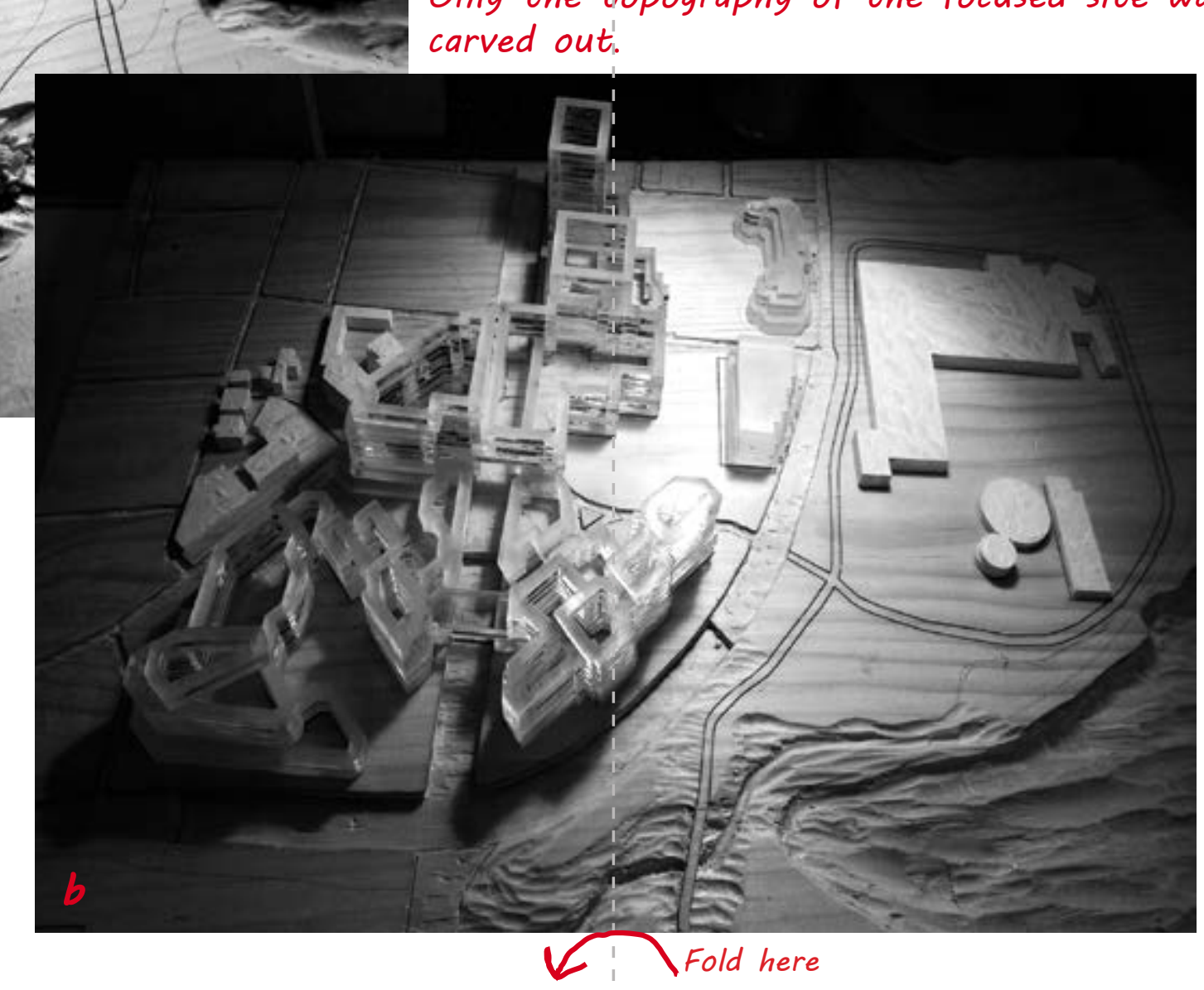

c The hollow acrylic massing casts shadows while absorbing light. Research on providing transparency into the building and governmental system.

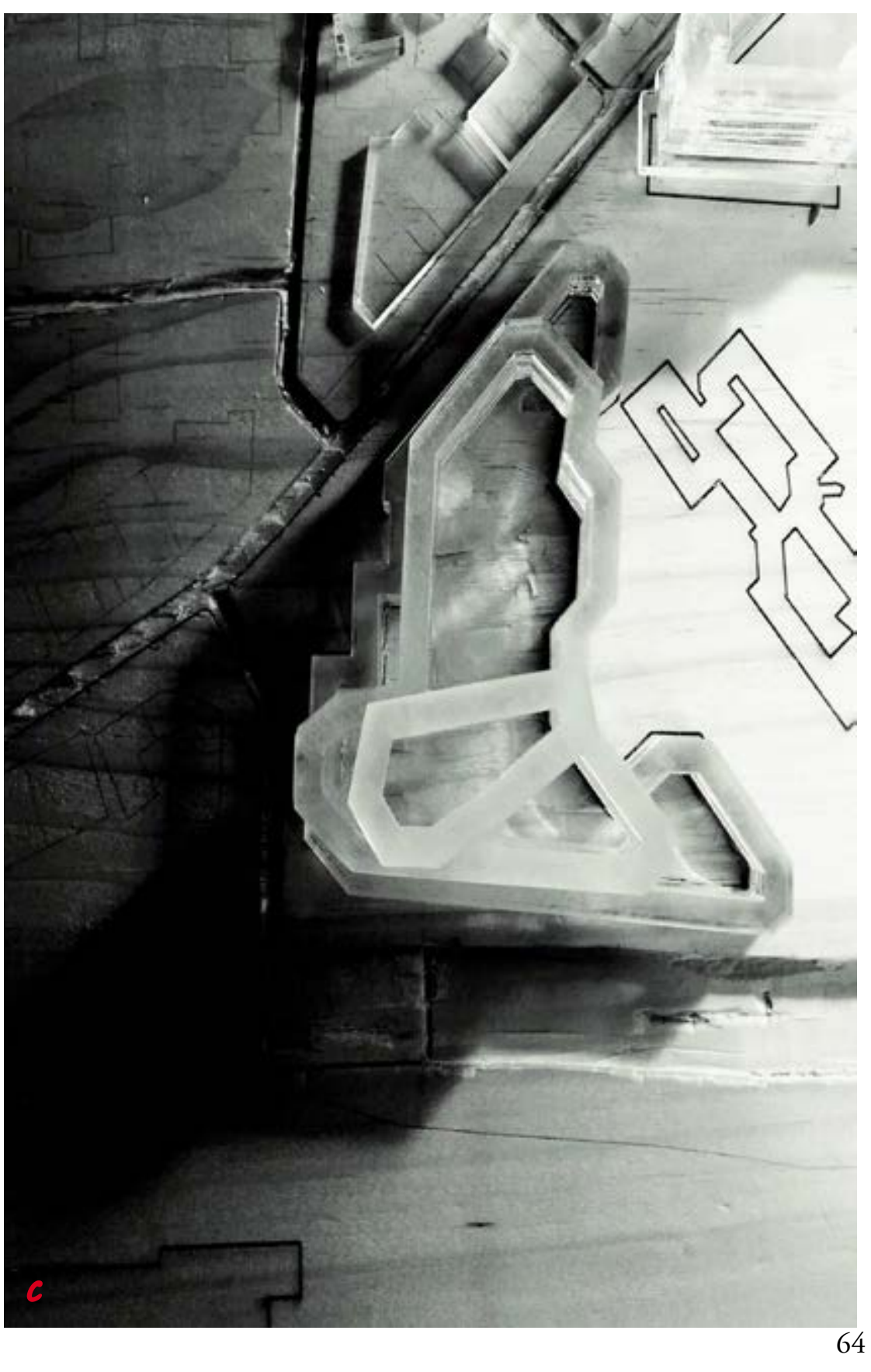




\section{PRECEDENT STUDIES}

This part of the research is an extended investigation beyond the geographical limits of the proposed site. Precedent studies in selected cities are chosen to draw a parallel with the City of Shadows regarding similarities in cultural and historical challenges.

in cultural and historical challenges.
The cities under survey are Quebec City, Montréal, Baltimore and Washington D.C.

As per Confidentiality Agreement clause 46c this evidence cannot be shown to private consultant.

Ilustrations 48 a-d

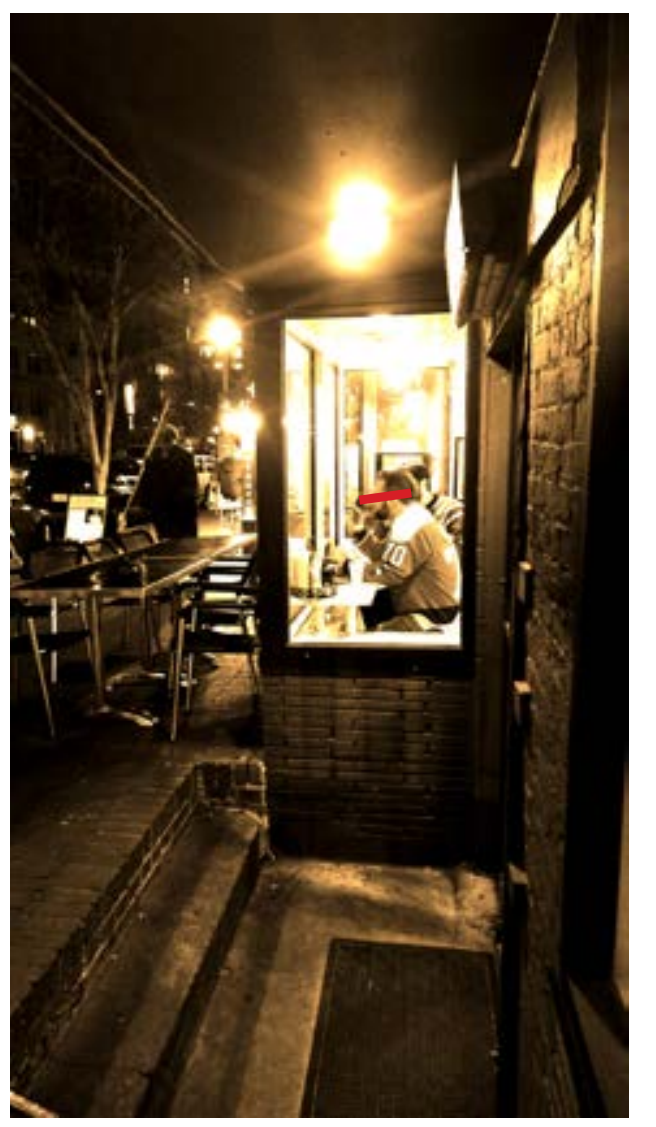

a Documented in Washington DC Interesting architectural moment captured on a busy street.

Note the extension of the building to facilitate the transition of programme.

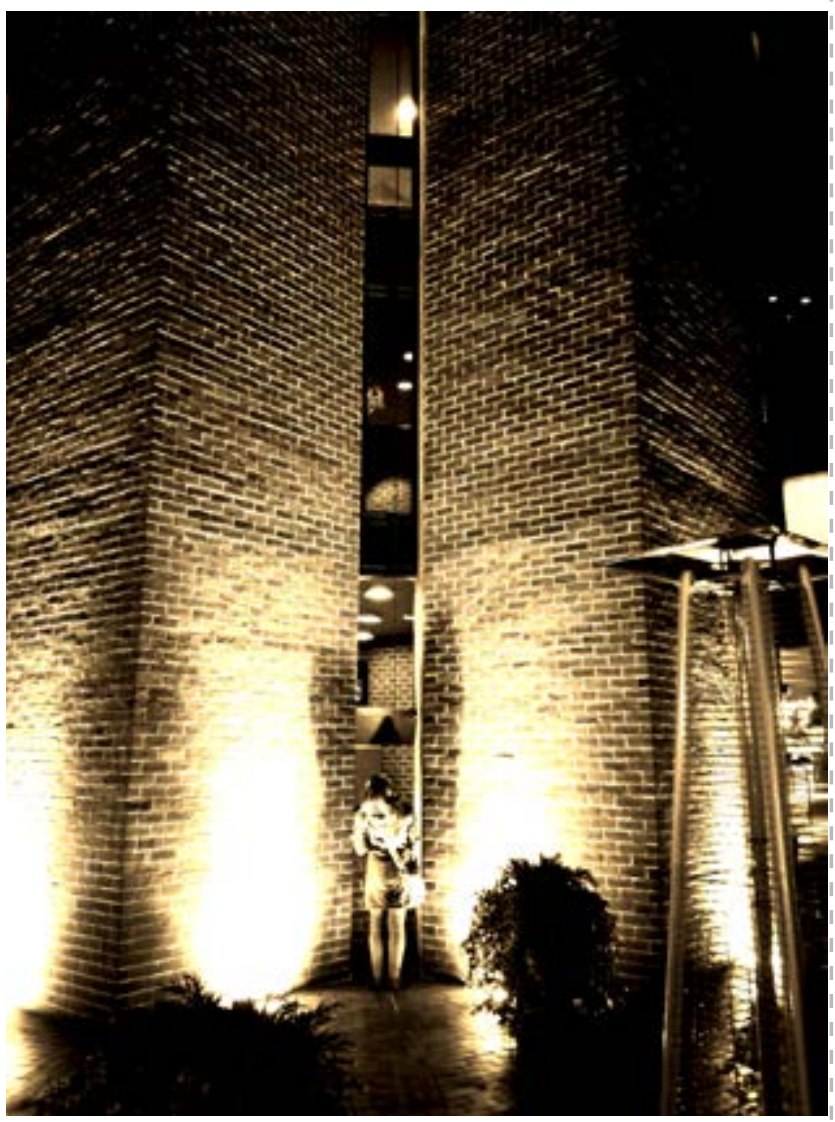

6 Documented in Washington DC in Georgetown. Triple height volume in an intimate courtyard.

Note the verticality of the gesture catching the attention of the viewer.

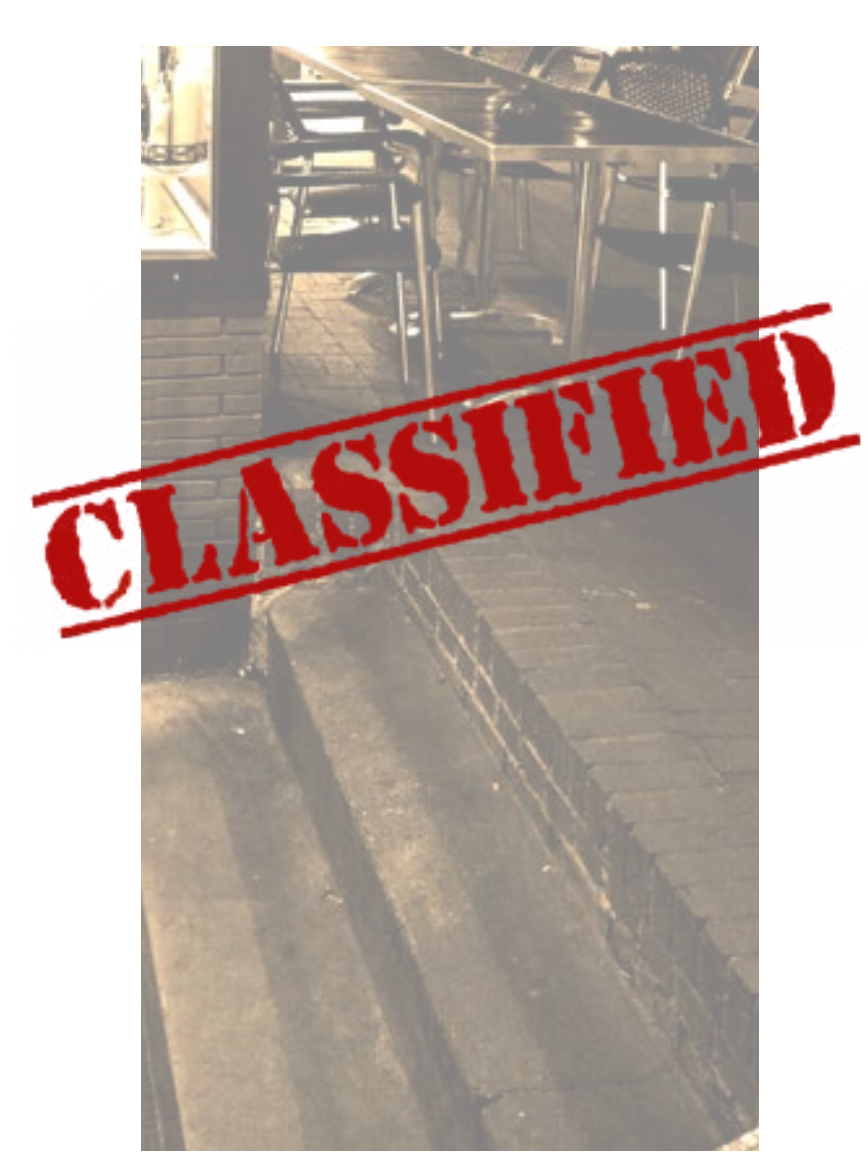

$C$ Documented in Montreal, Qc. Hidden entrance of an underground bar on Saint-Denis street. A password is required to get in and access the estabtishment.

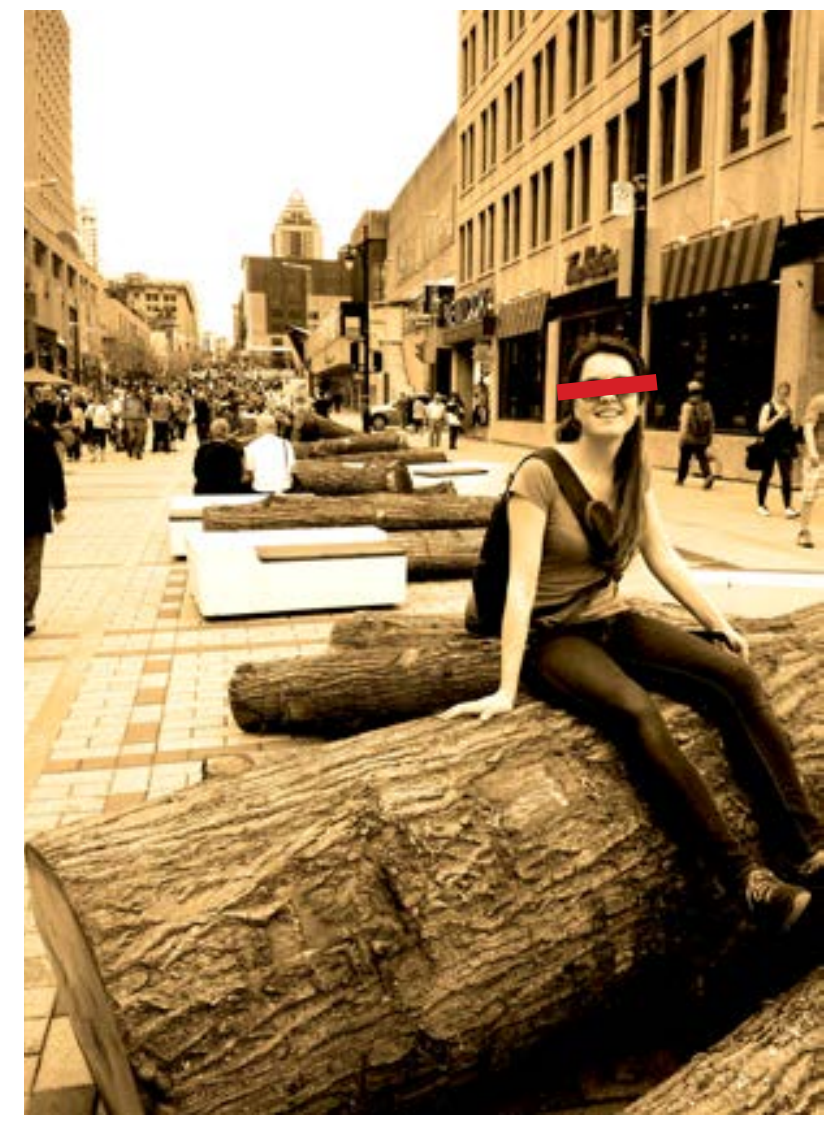

d Documented in Montreal, Qc. Temporary exhibition on timber industry and the expression of the extensive journey along Saint Lawrence River. 
AFFAIRES INTERNES

Québech

Ilustrations 49 a-e
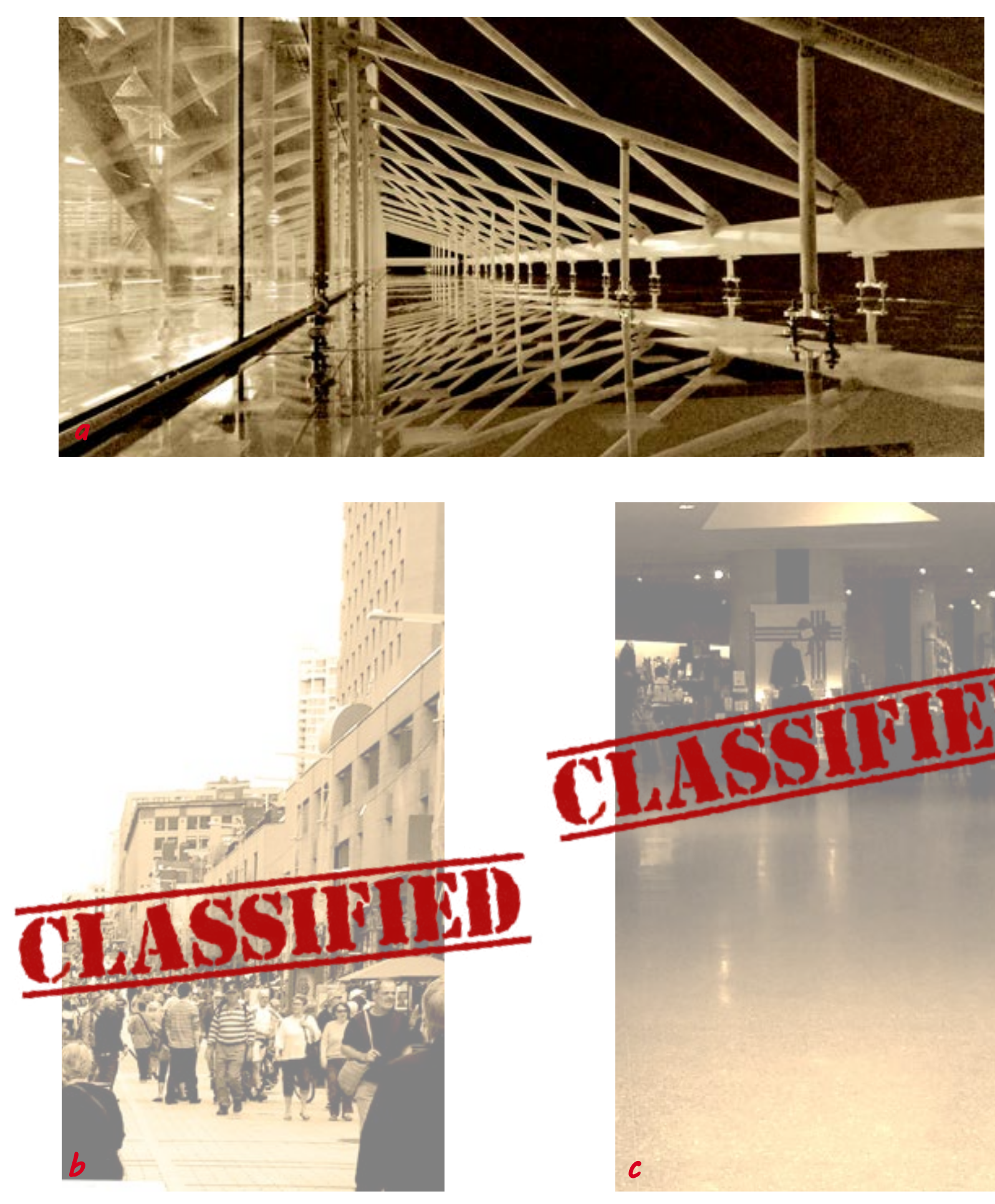

Fold here

'As per Confidentiality Agreement clause 46 b,c the evidences cannot be shown to private consultant.

a In DC. Interesting continuity with play of reflection with the actual structure of the building. Can be interpreted as vertical or horizontal space.

$b$ th QC. Documentation of public interaction in a transitional space surrounded by large scale buildings.

c In QC. Vertical light penetration between an underground sanctuary and the street level. Discrete but effective.

id In QC. Archeological site underneath a public plaza overlooking on Saint Lawrence River. The lightwells allow the viewers on the plaza to observe the under ground site.

e In DC. The National Art Gallery has two buildings and the connection to both buildings is underground. Architectural play with the sklylights and landscape.
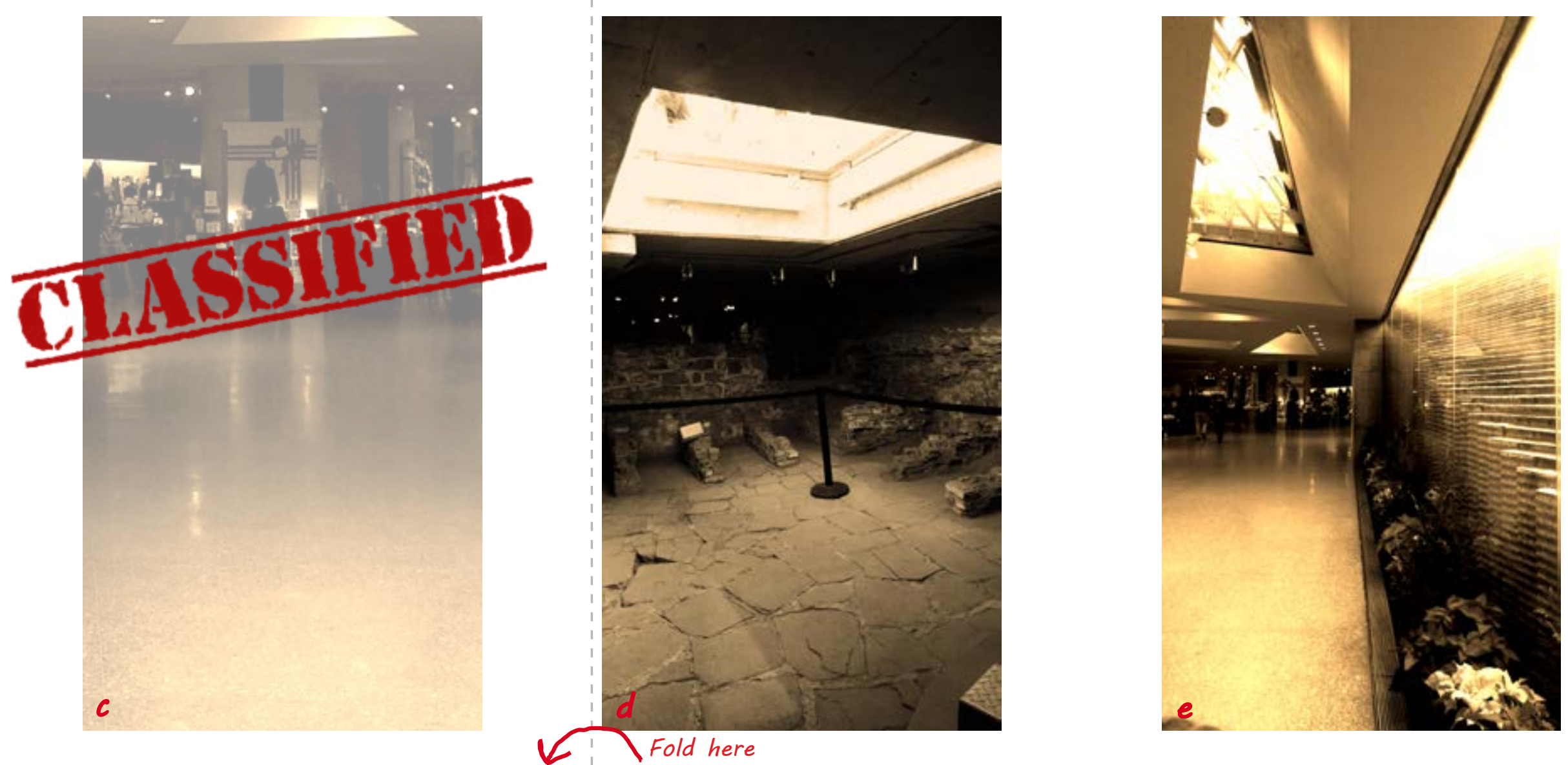


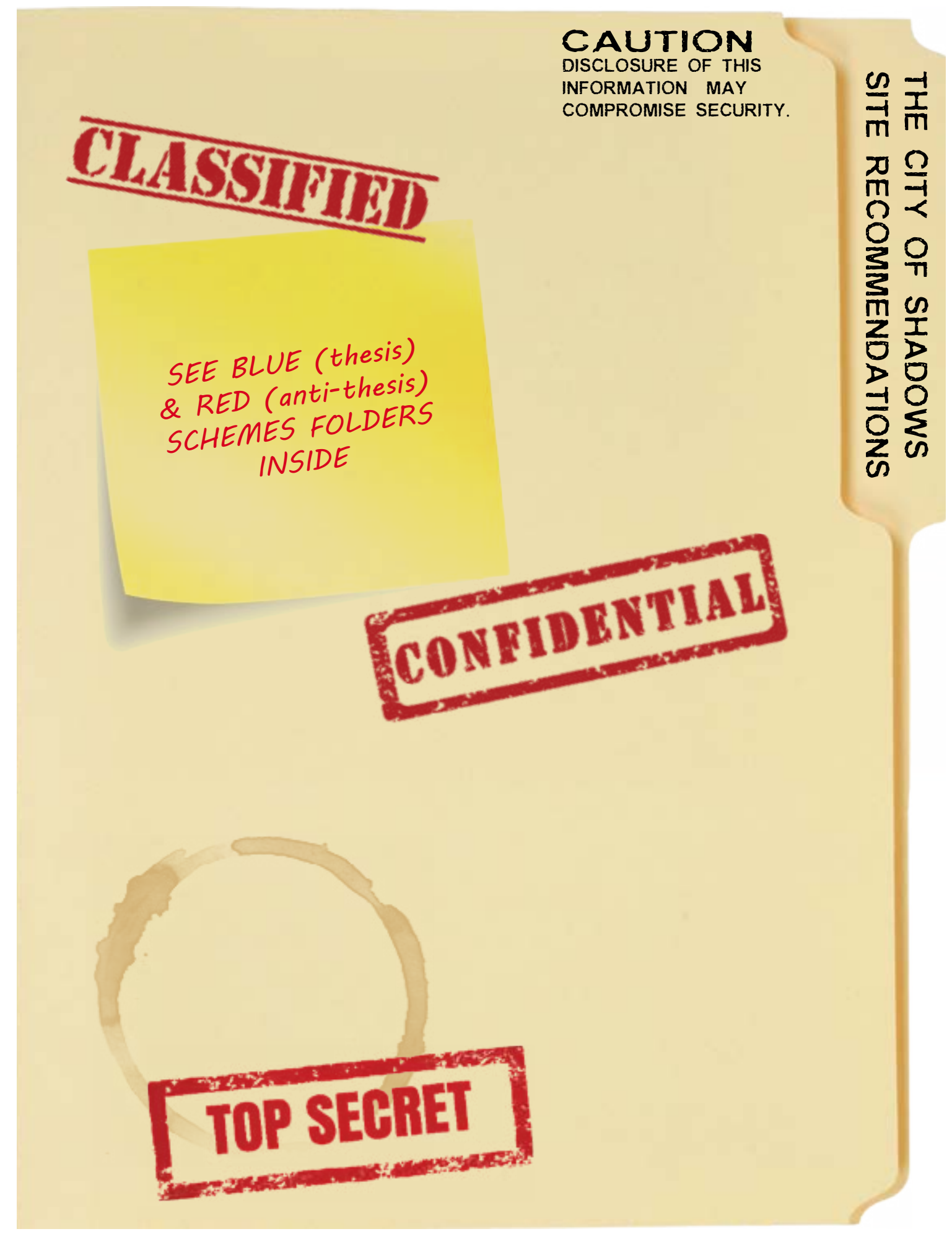




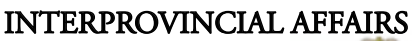 \\ Québec 渄}

As per Confidentiality Agreement clause 68a this page cannot be shown to private consultant.

\section{THE CITY OF SHADOWS - LA CITÉ DES OMBRES}

The thesis and anti-thesis vignettes are exclusively made from site visit photos of the Portage buildings and precedent studies documentation.

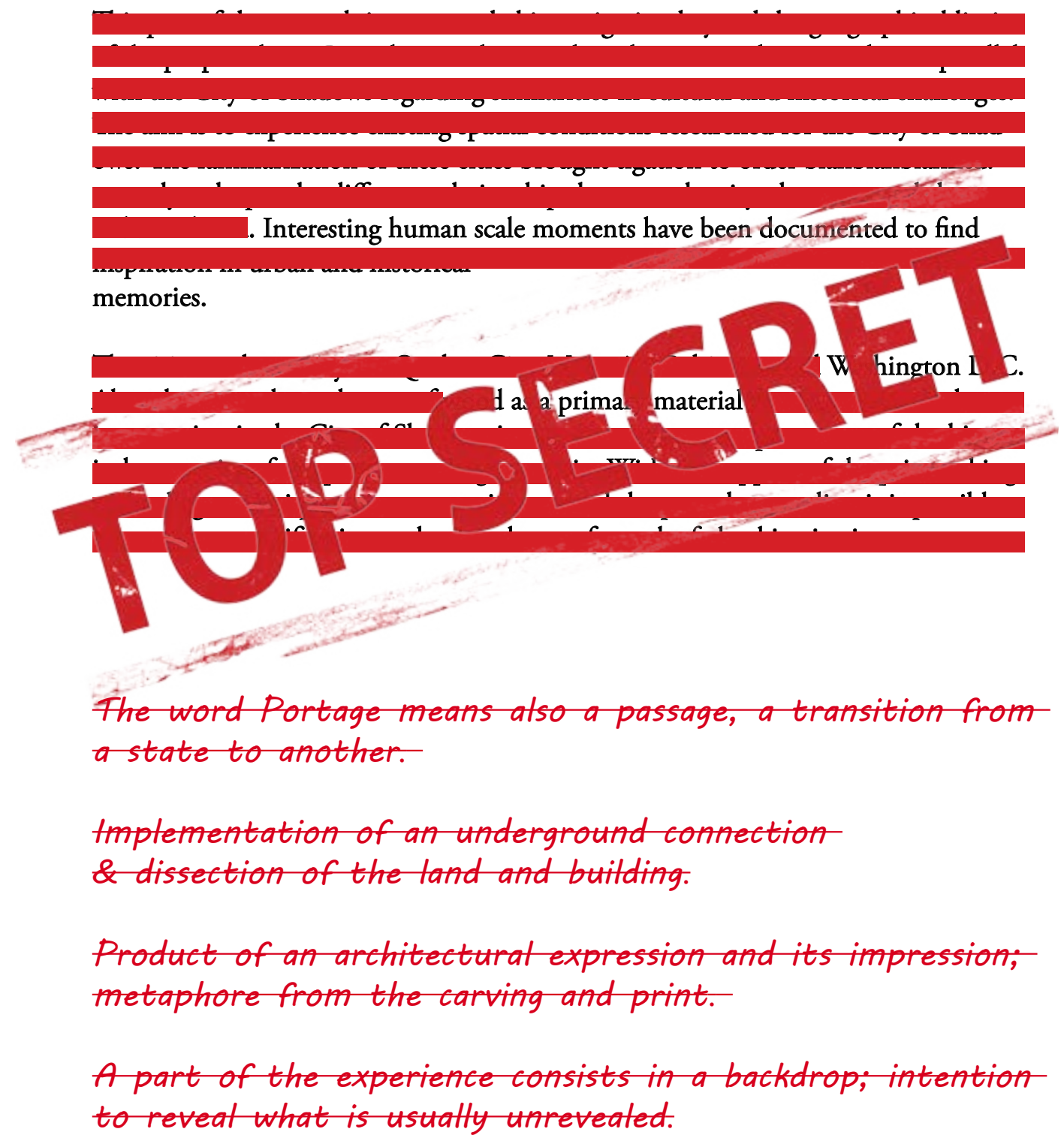




\section{PRELIMINARY DRAWINGS}

Illustrations $50 \mathrm{a}, \mathrm{b}$ Perspectives

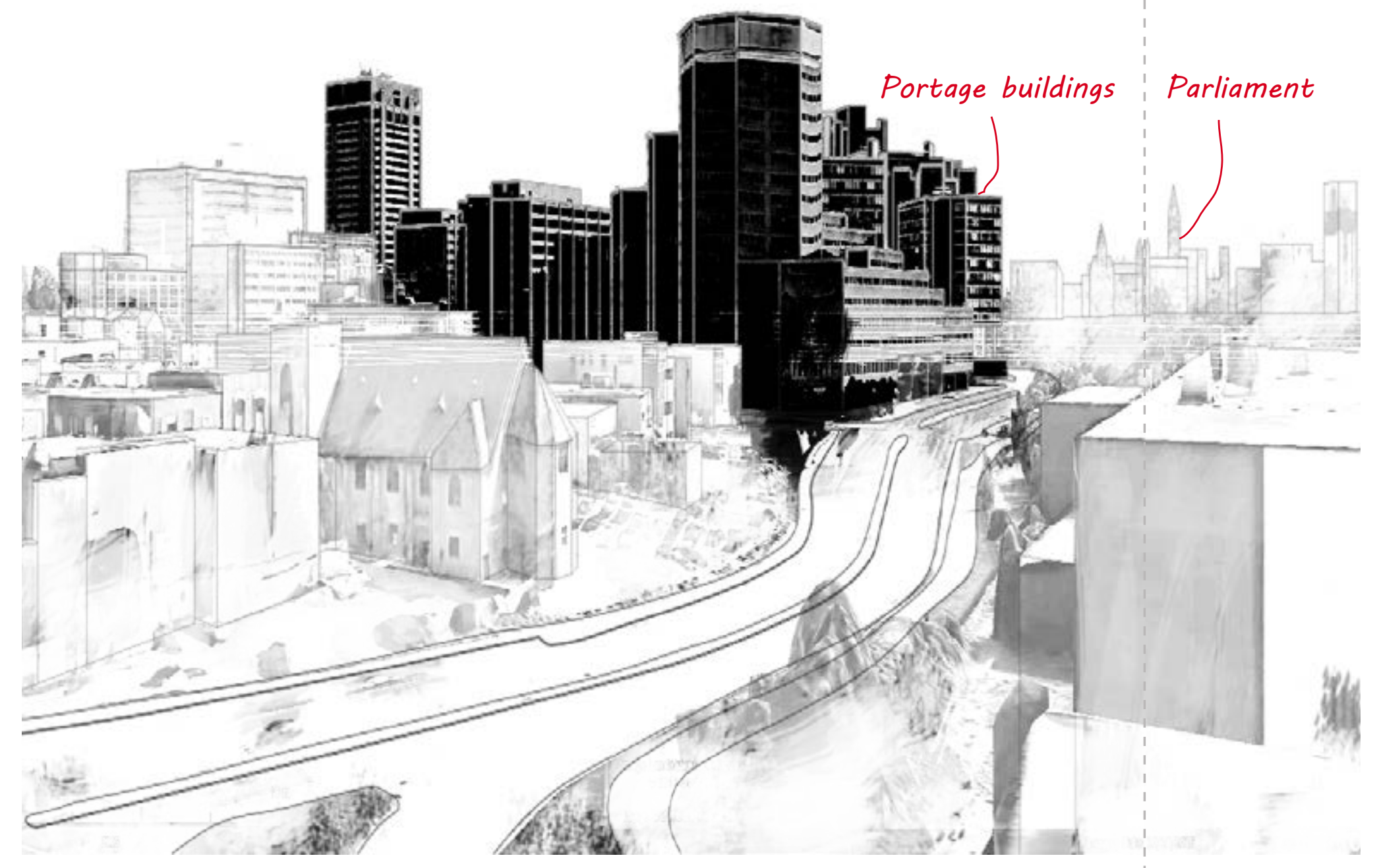

a Disruption in the urban fabric - between neighbourhood and shoreline caused by monumental scale of the Portage buldings

Government "overlooking" on the masses

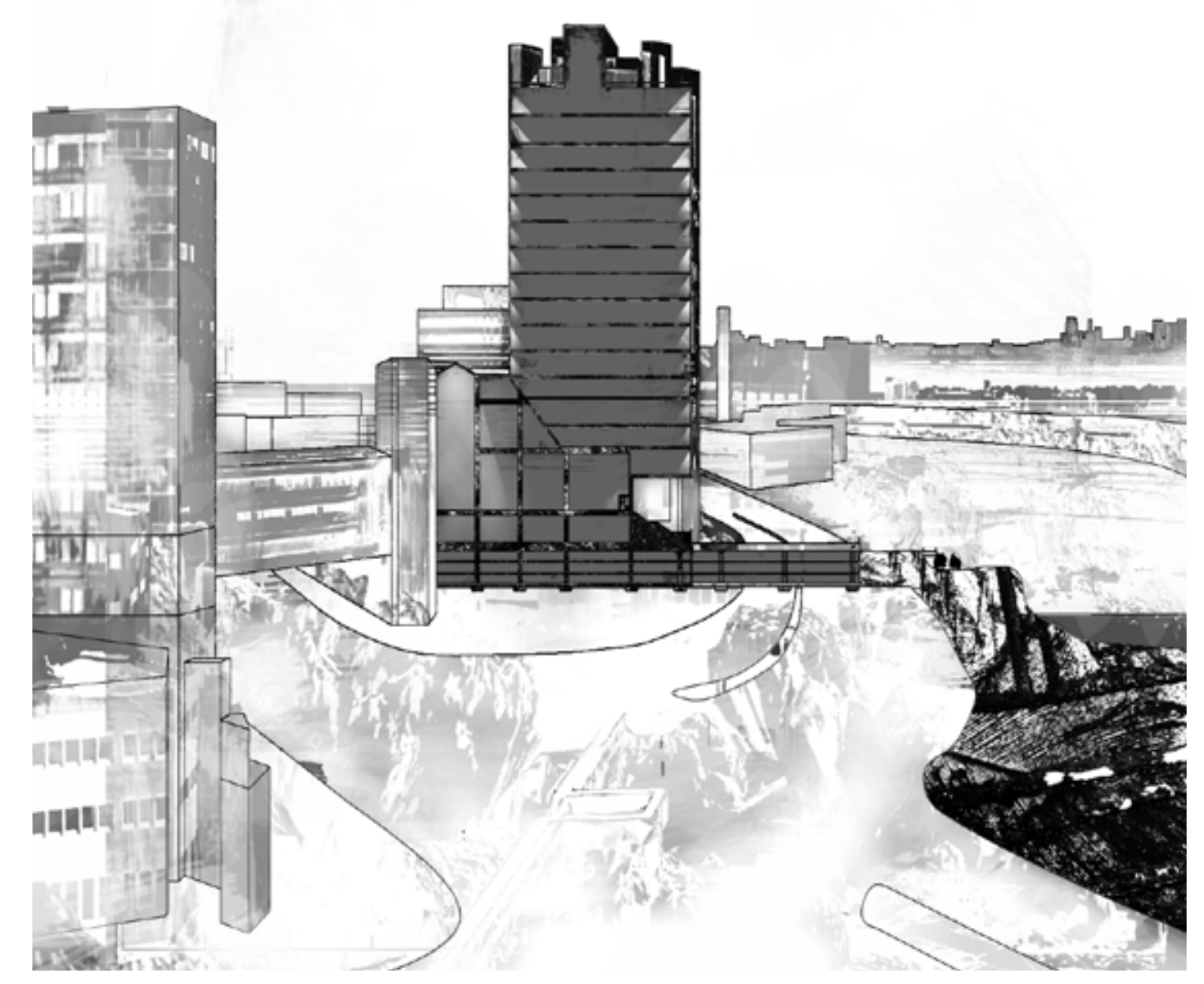

b Section of the Phase III of the federal complex (office floors, atrium, underground parking P7 \& P2) Underground parking is the place of operation 


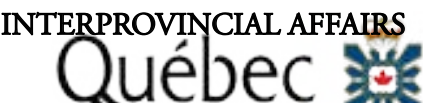

\section{PRELIMINARY DRAWINGS}

Illustration 51 Section

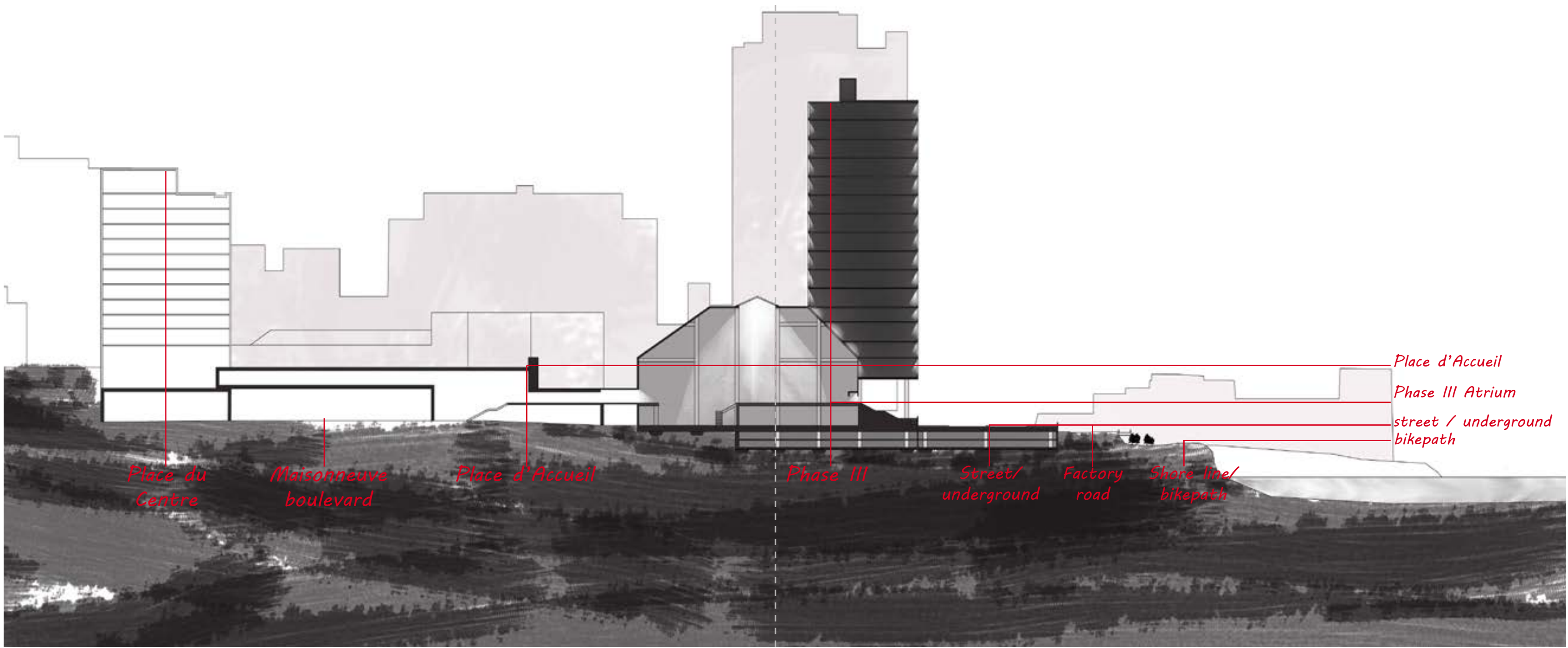

Transparency?: Should people have the possibility to see what is happening? ... Alienation of work and "management" of society Intent of operating on vertical and horizontal points of reference to penetrate through the underground

See Ground plan...

$$
1 \text { Fold here }
$$




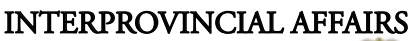 \\ Québec 海}

\section{PRELIMINARY DRAWINGS}

\section{Illustration 52 Ground Plan}

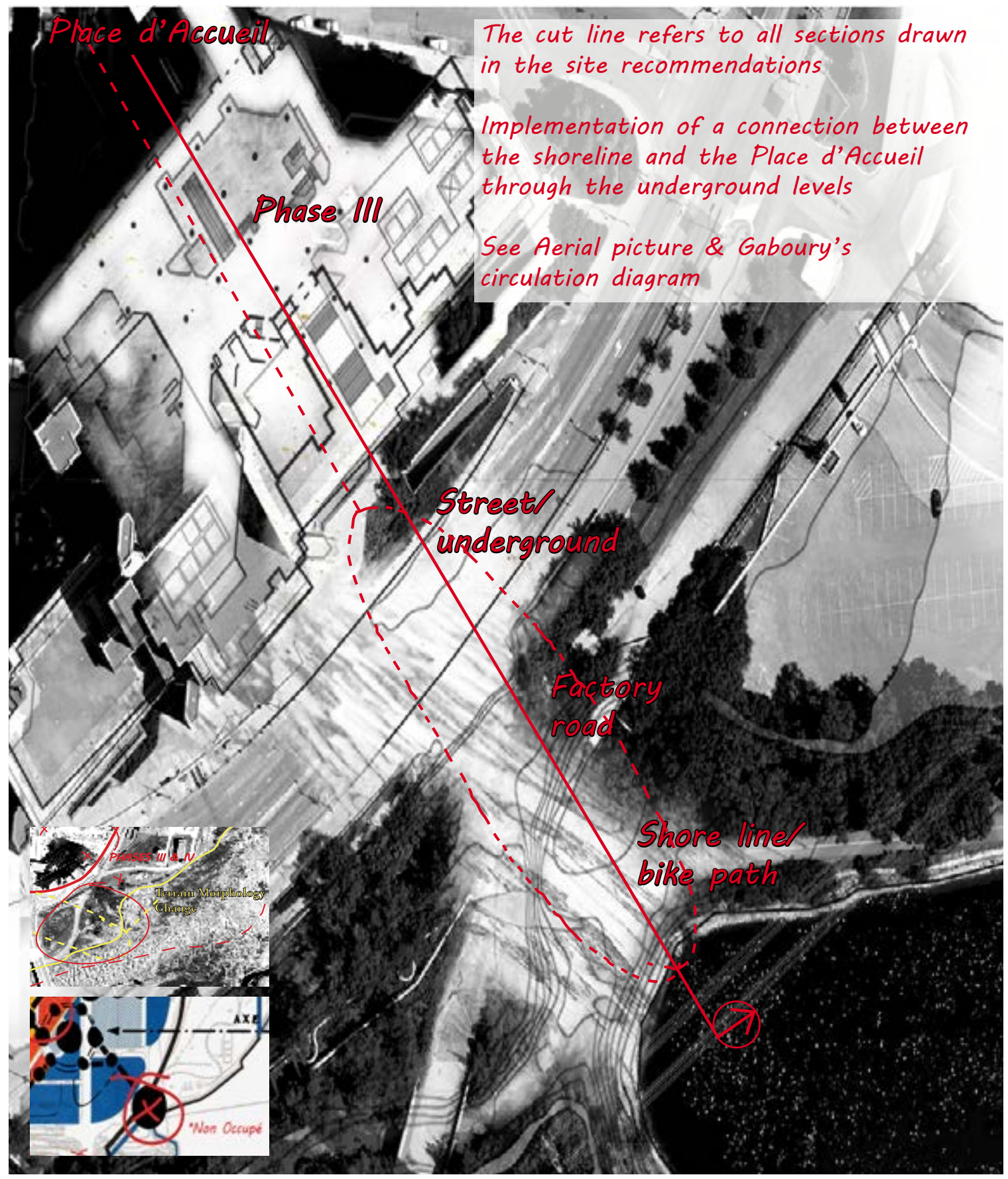




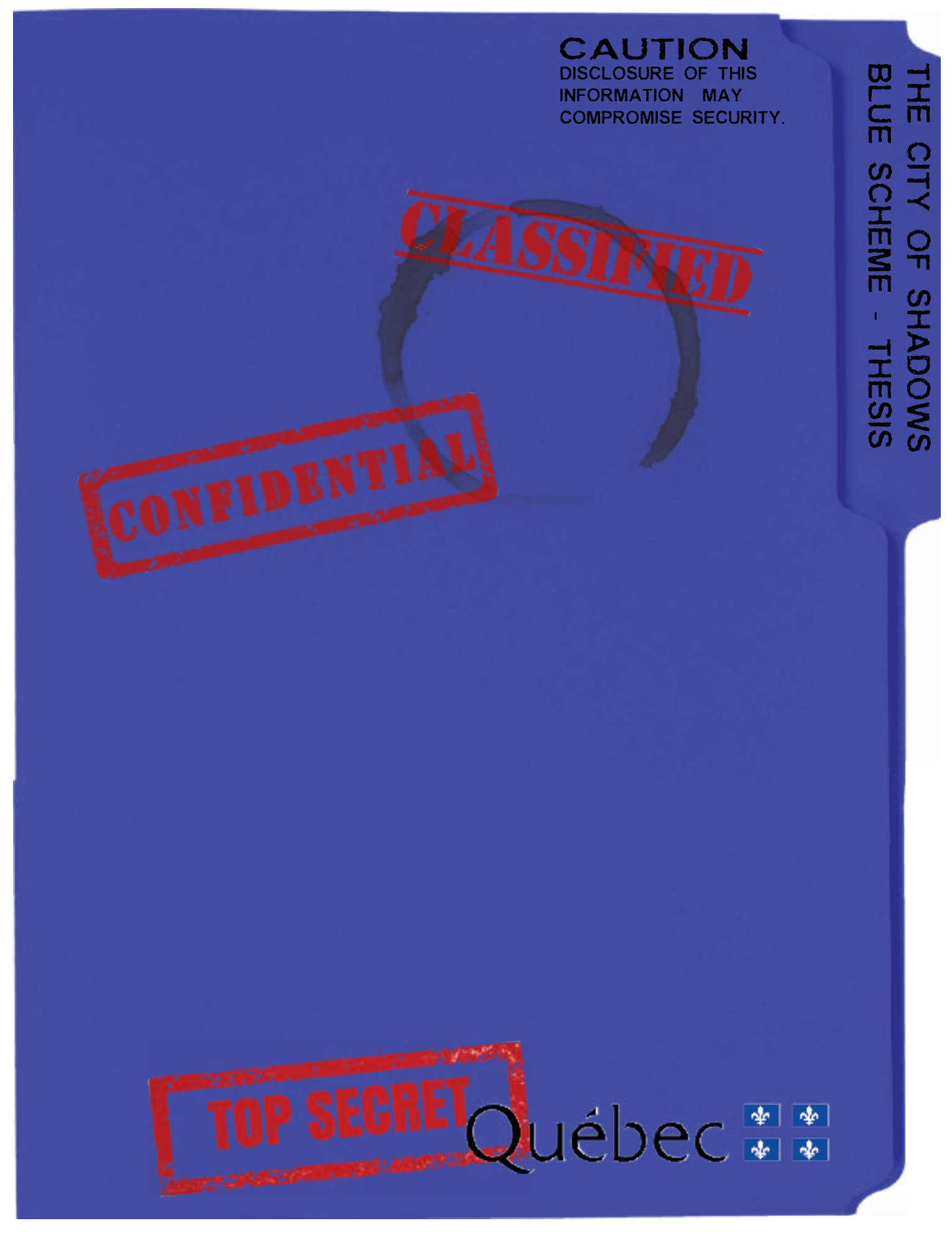




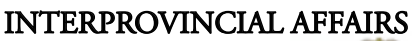 \\ Québec 漈}

\section{BLUE SCHEME - THESIS}

\section{Illustration 53 Underground parking (P1 \& P2)}

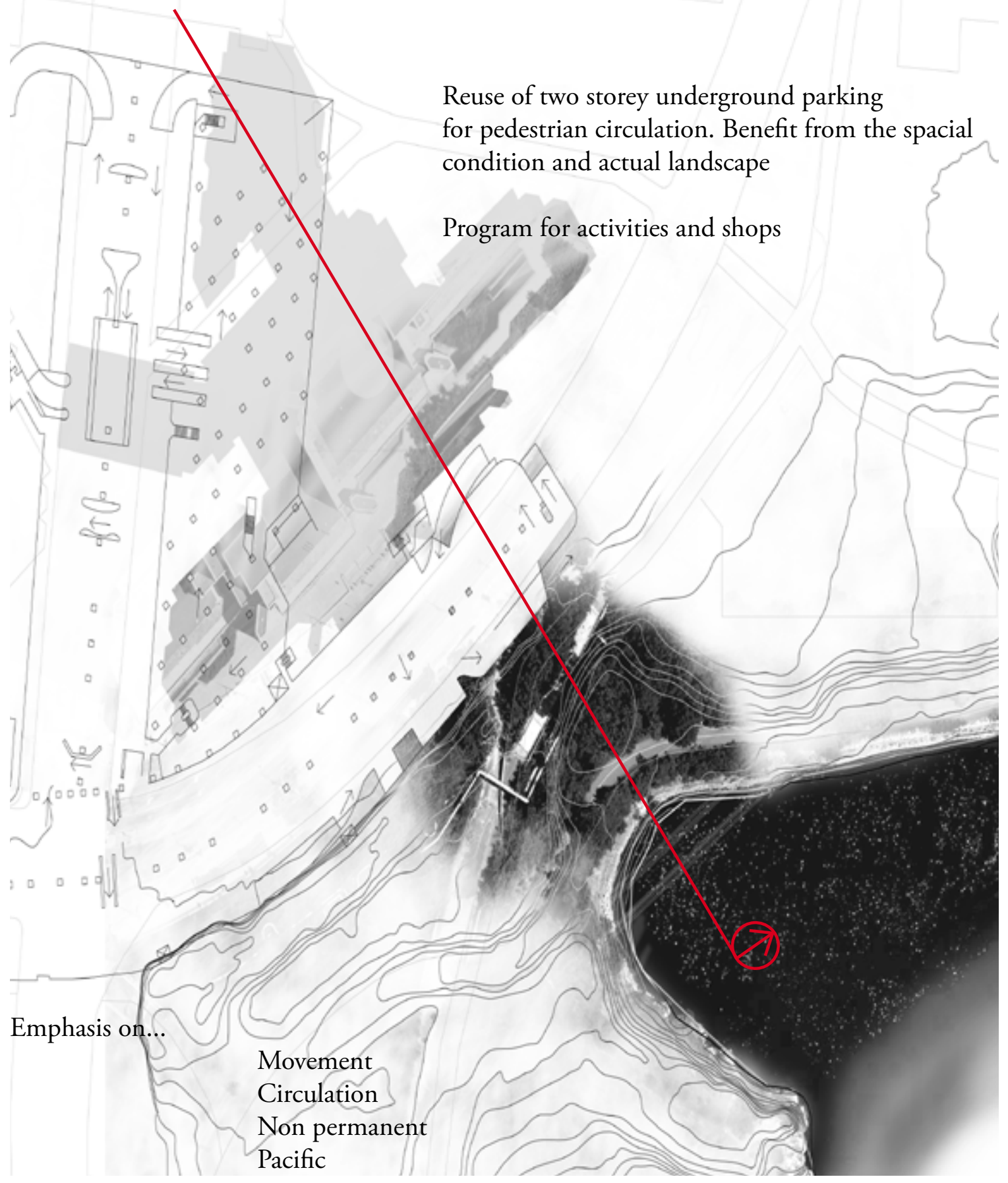




\section{BLUE SCHEME - THESIS}

Illustration 54 Longitudinal Section

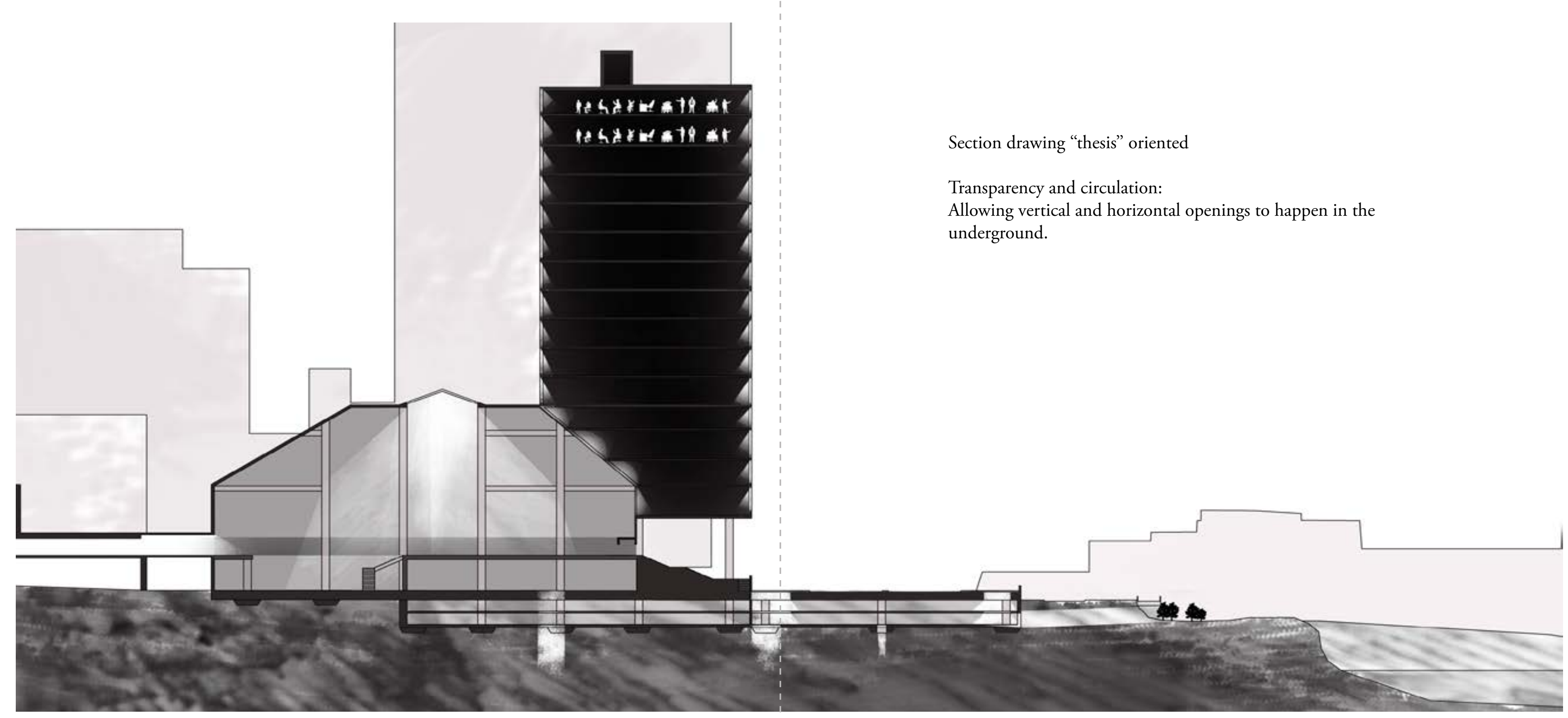




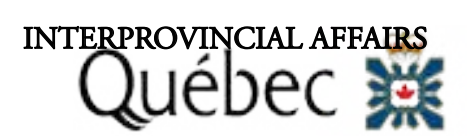

\section{BLUE SCHEME - THESIS}

Illustration 55 Longitudinal Section - Underground

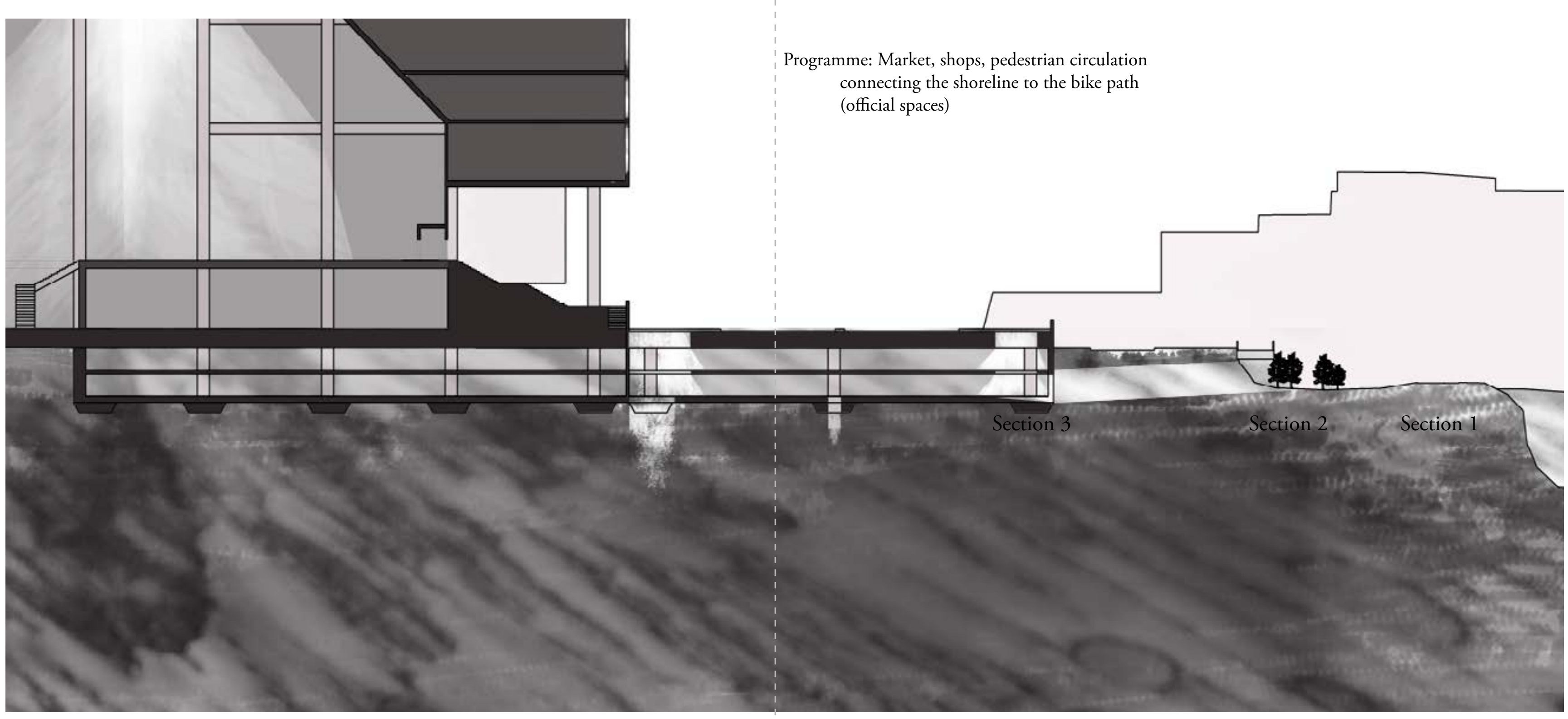

Although the Truth is happening in disguised and non-official spaces...

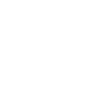

! connecting the shoreline to the bike path
Fold here 
BLUE SCHEME - THESIS

STUDY \#9 : SECTIONAL MODEL

Illustrations 56 a-c

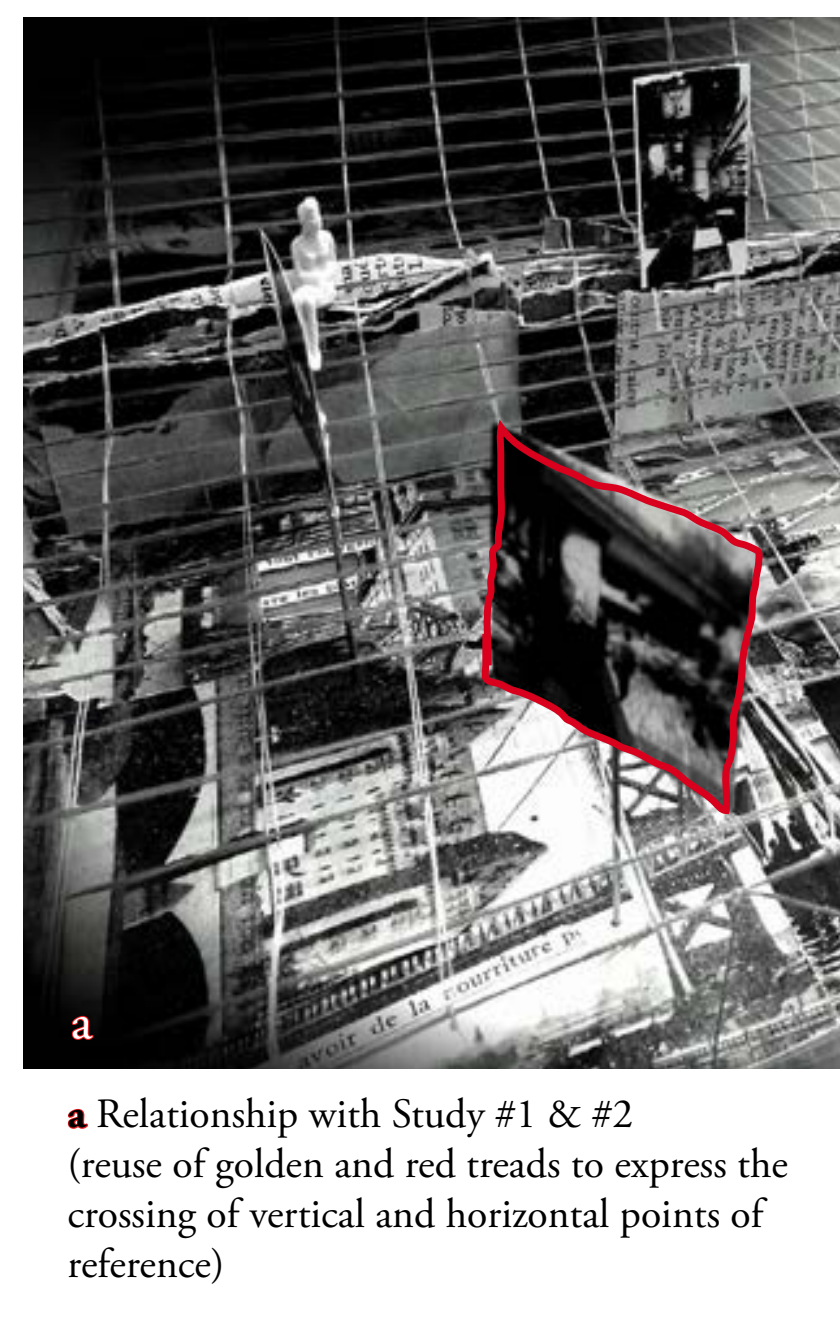

b The treads allow transparency into the sectional model, to see what is happening below the surface the ground
The sectional model offers two point of views: cross section and longitudinal section. There are at least four different points of interaction:

Building level, street level, underground parking level(s) and bike path level.
As per Confidentiality Agreement clause $51 \mathrm{c}$ this evidence cannot be shown to private consultant.

c Eollage hidden below the tread topography. It informs about the history of the tand and how it influences sociat interactions

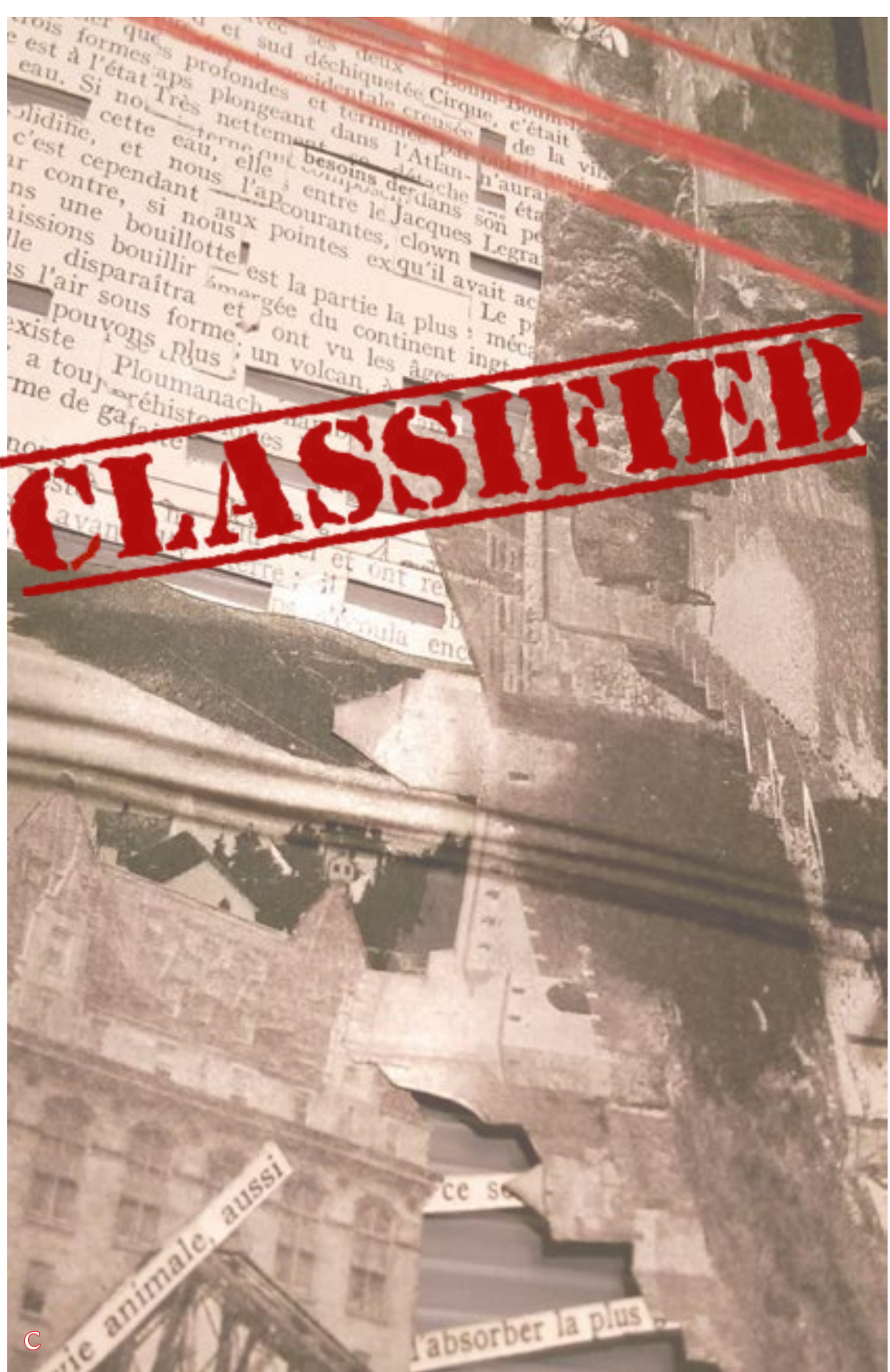




\section{BLUE SCHEME - THESIS}

Illustrations $57 \mathrm{a}, \mathrm{b}$ Vignettes $1 \& 2$

Each vignette relates to a moment happening in each section. The section drawings help to structure the sequence of events. Compare vignettes with sections.

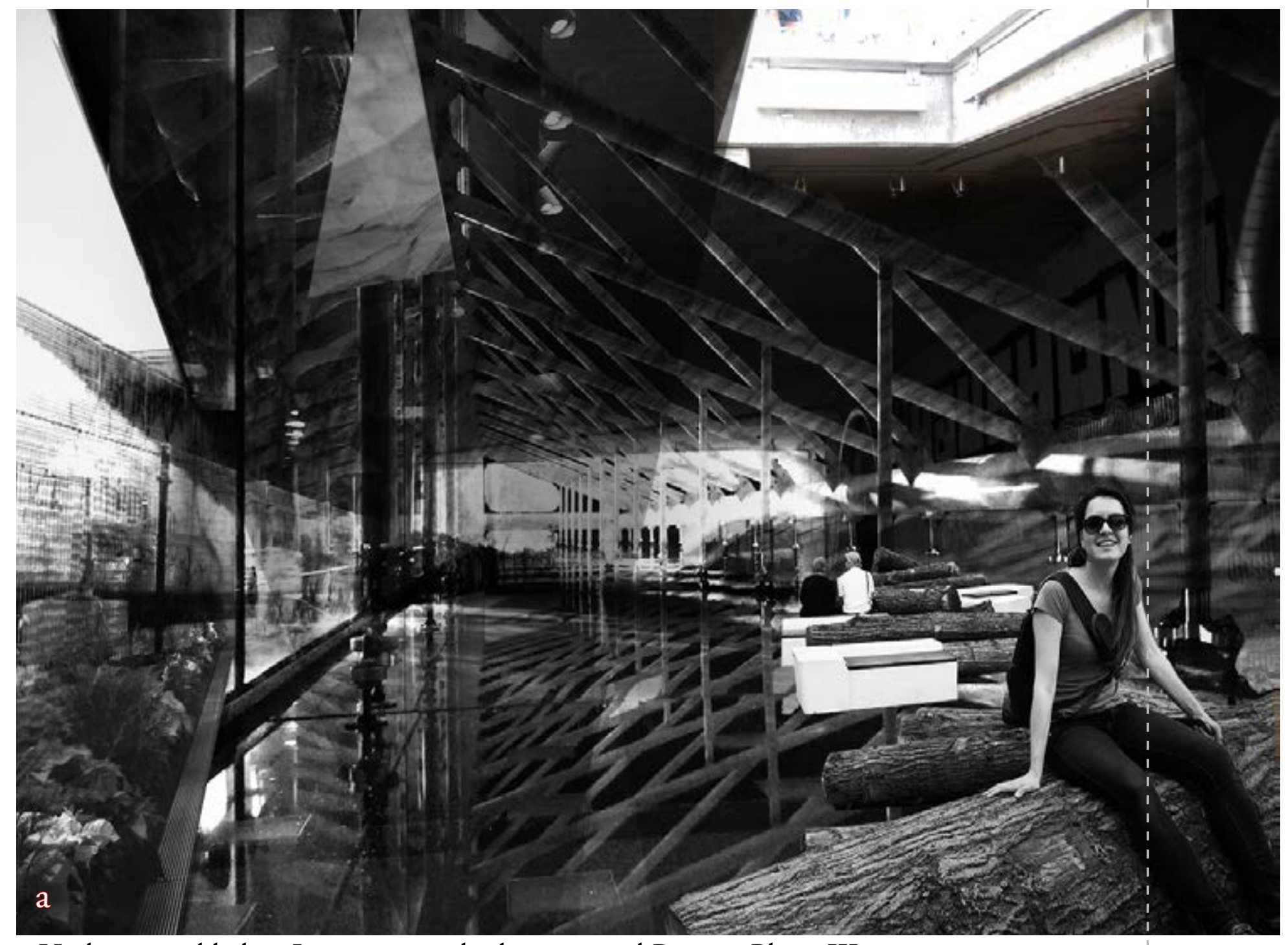

Underground below Laurier street looking toward Portage Phase III

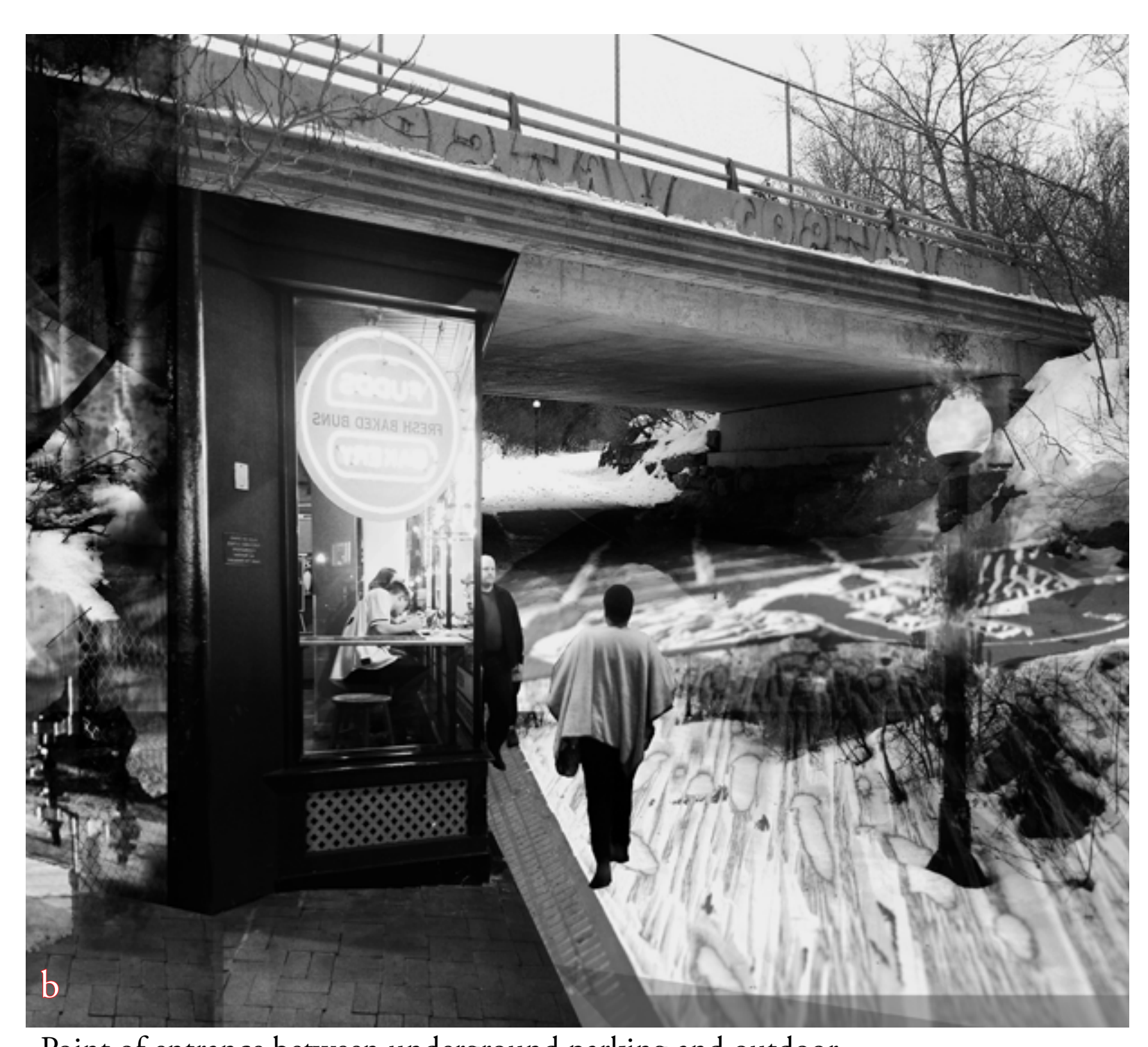

Point of entrance between underground parking and outdoor 


\section{BLUE SCHEME - THESIS}

\section{Illustrations $58 \mathrm{a}, \mathrm{b} \quad$ Sections $1 \& 2$}

Vignettes:

Soft treament of light, low contrast, excavation of materiality, sensorial experience

Section drawings:

Emphasis on Movement, Circulation, Ephemeral, Passivity

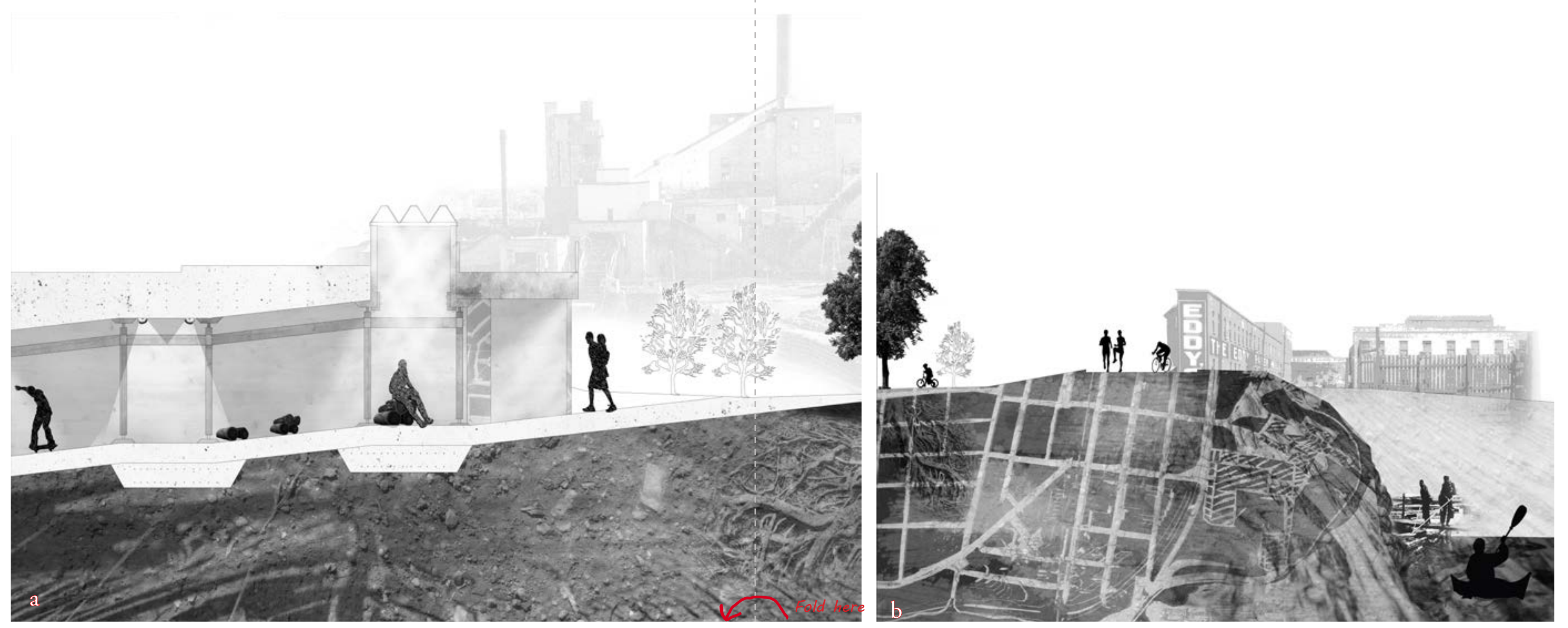




\section{Québec 鶹}

\section{BLUE SCHEME - THESIS}

\section{Illustration 59 Vignette 3}

Vertical opening linking the underground level with Laurier street

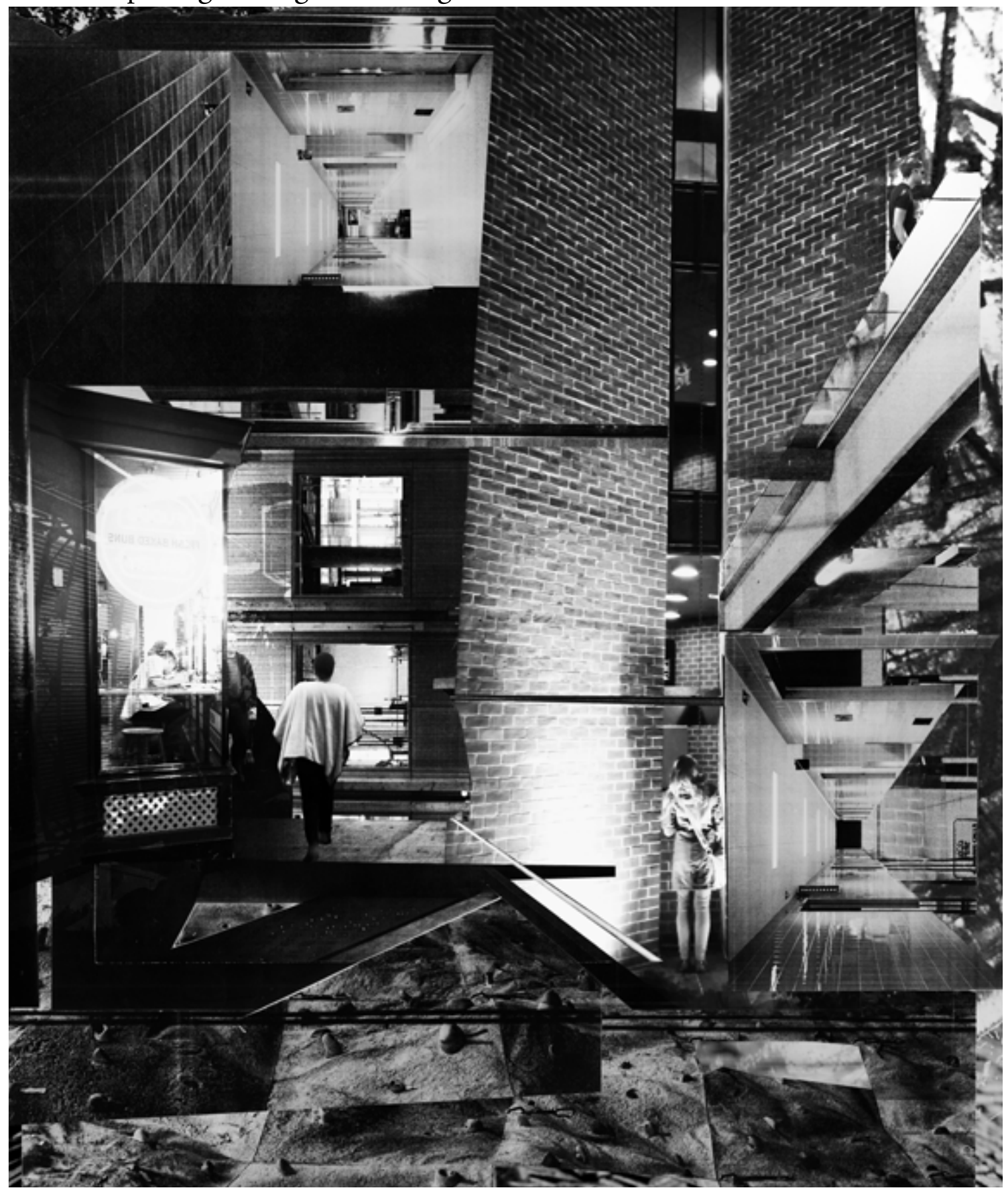




\section{Québec 菢}

\section{BLUE SCHEME - THESIS}

\section{Illustration 60 Section 3}

This section drawing relates to Vignette 3 . The section provides a context to frame the experience.

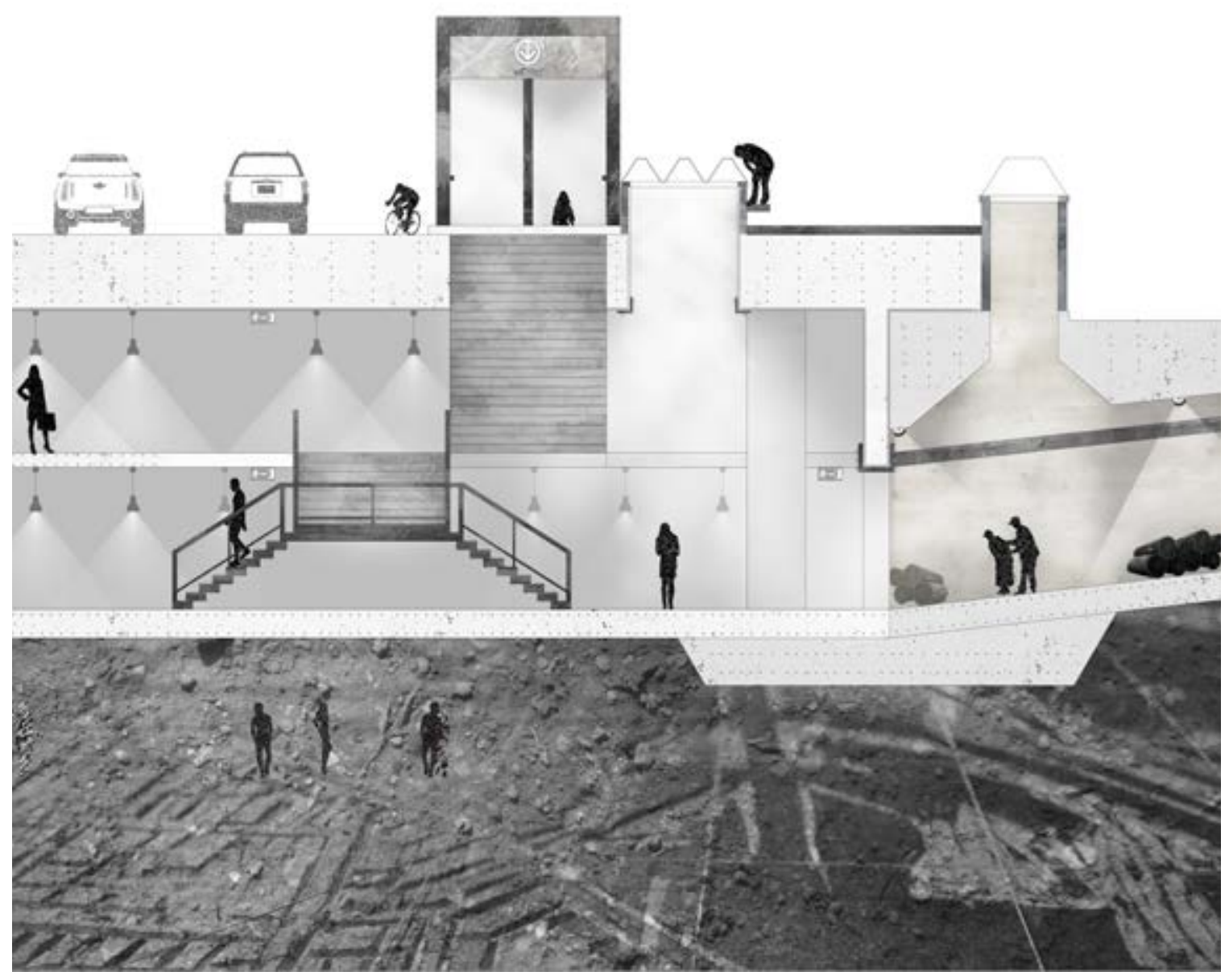

Meanwhile..."Movement is felt from P2; vibration, noise...there must be something else happening below our feet..." 
CHASSIPIDI

CAUTION

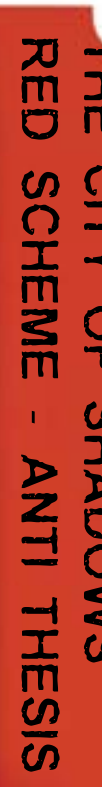

COTHIDENTIA

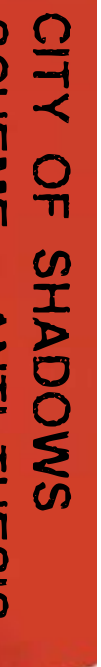

TOP SEGRE Québec **

81 


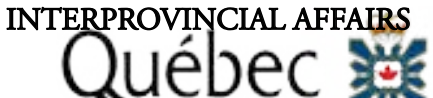

\section{RED SCHEME - ANTI THESIS}

Illustration 61 Longitudinal Section
Fold here

Questions:

How to give back to the individual?

How to raise the viewed to the same level of power?

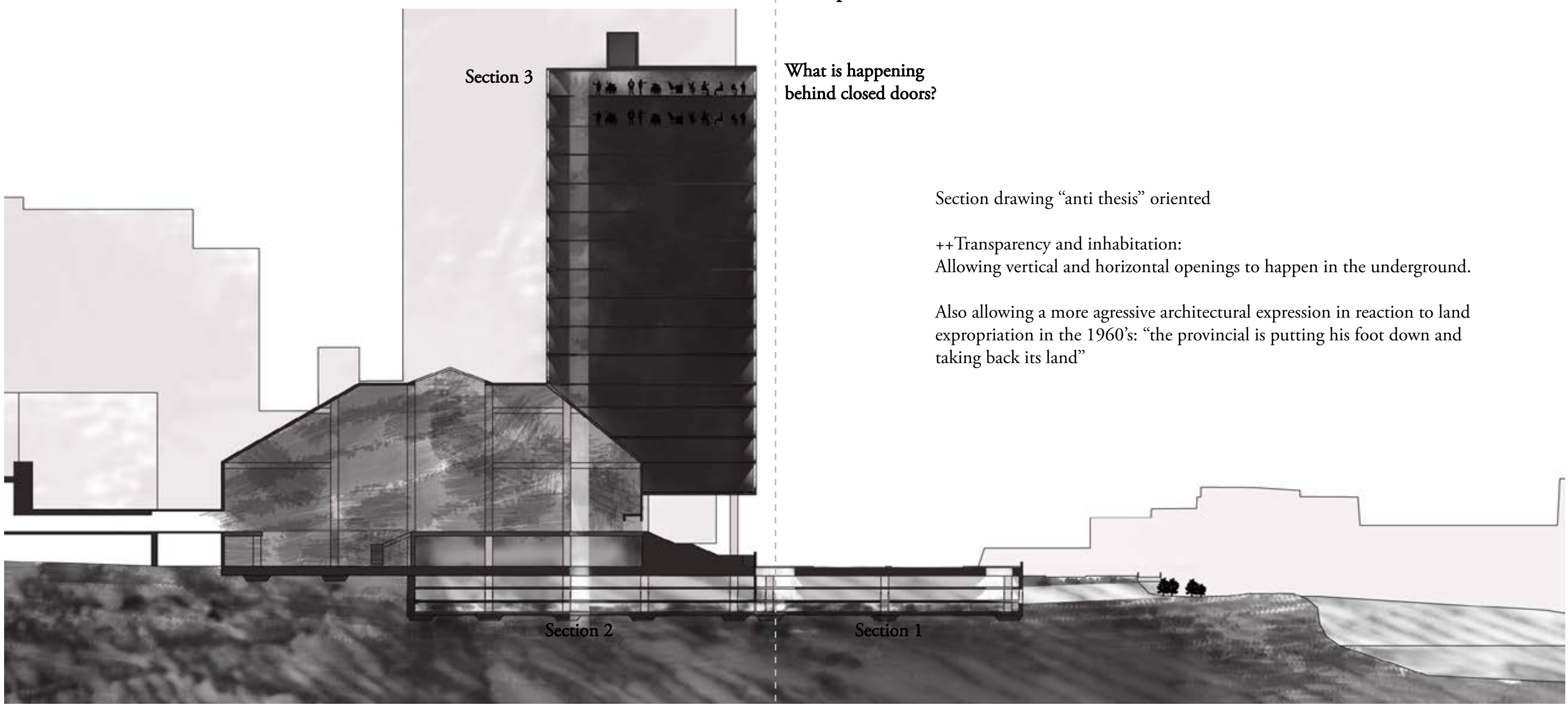




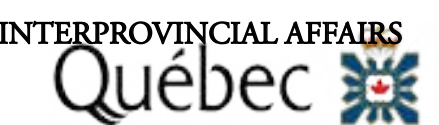

\section{RED SCHEME - ANTI THESIS}

\section{Illustration 62 Longitudinal Section - Underground}

A third level of underground is accessible through disguised openings from the second level of underground parking. This is the transition between the thesis and the anti thesis; between a public space and a BLACK MARKET.

Allowing to show to the public things kept behing closed doors ("Unreveal")

The moment of transition is the "Grey Zone" (... beginning of synthesis...)

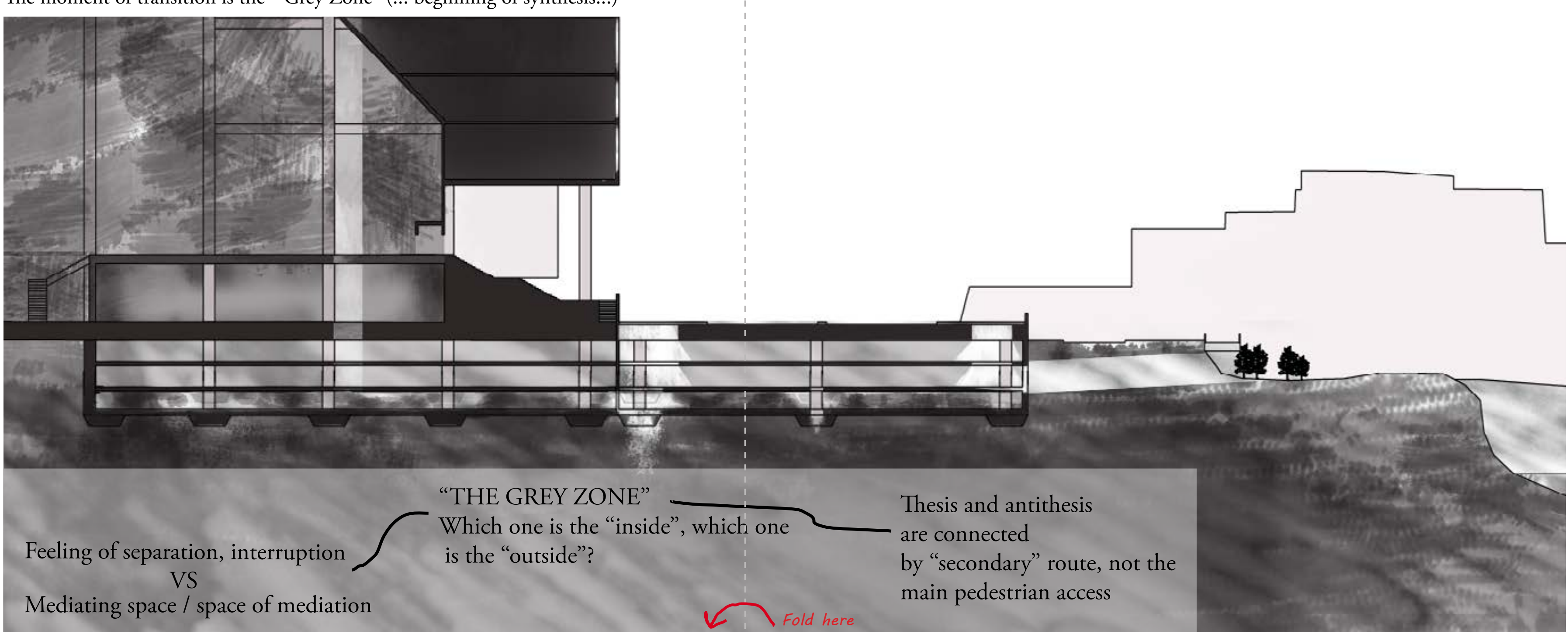




\section{INTERPROVINCIAL AFFAIRS \\ Québec 海}

\section{RED SCHEME - ANTI THESIS}

\section{Illustration 63 Underground parking (P3)}

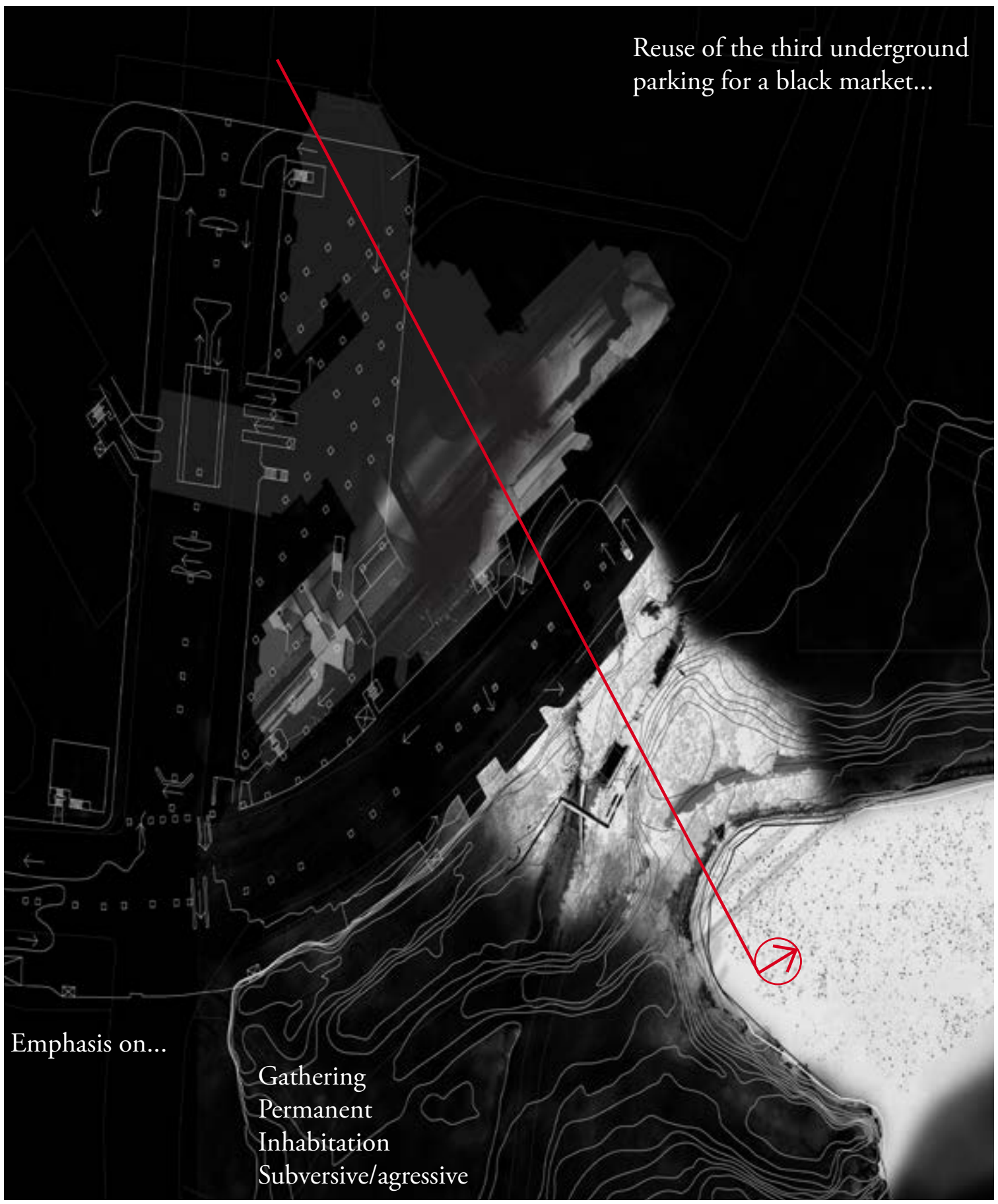




\section{RED SCHEME - ANTI THESIS}

Illustration 64 Section 1 (for Vignettes 1-2-3)

Each vignette relates to a moment happening in this section drawing. The collages section drawings help to structure the sequence of events.

Compare vignettes with this section.
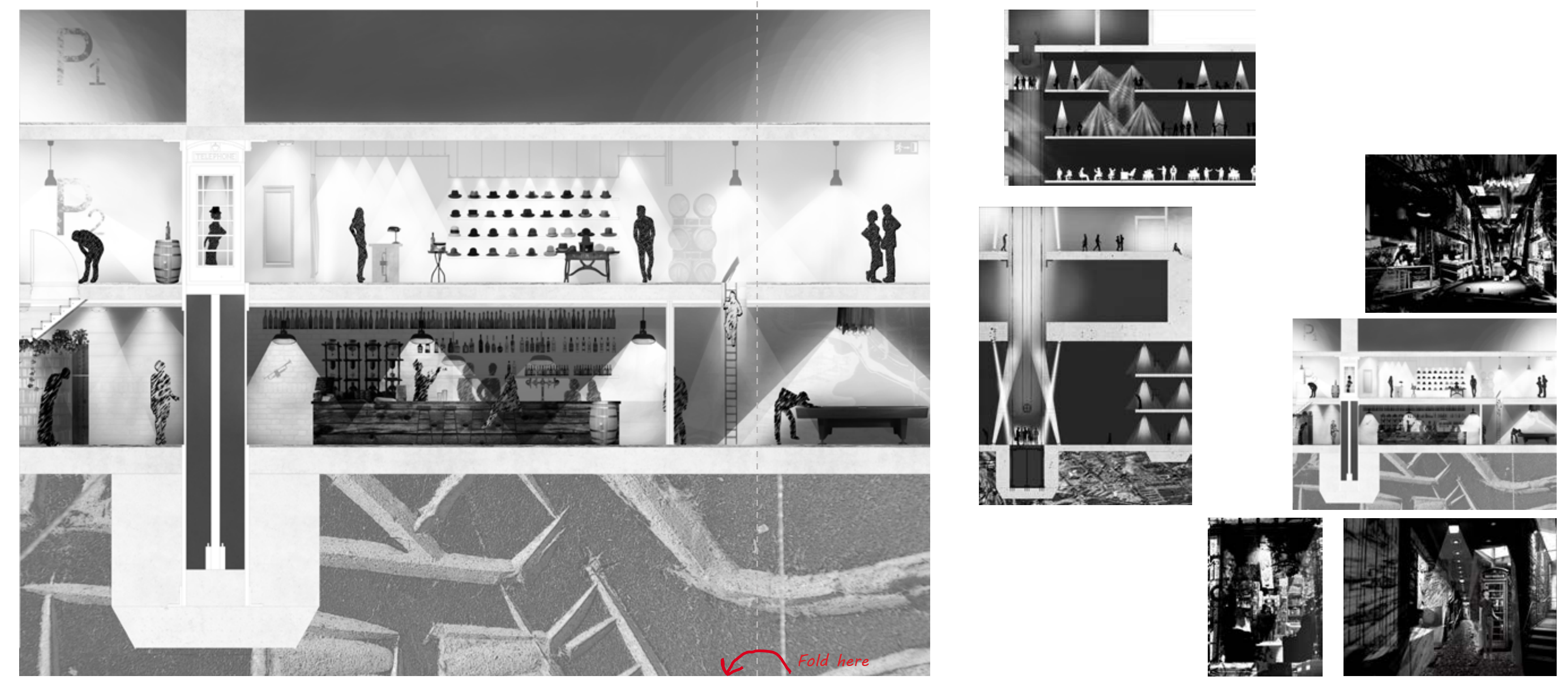


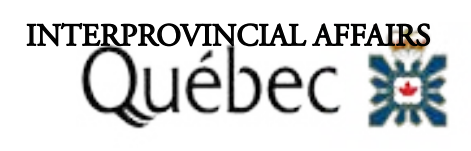

RED SCHEME - ANTI THESIS

Illustrations $65 \mathrm{a}, \mathrm{b} \quad$ Vignettes $1 \& 2$

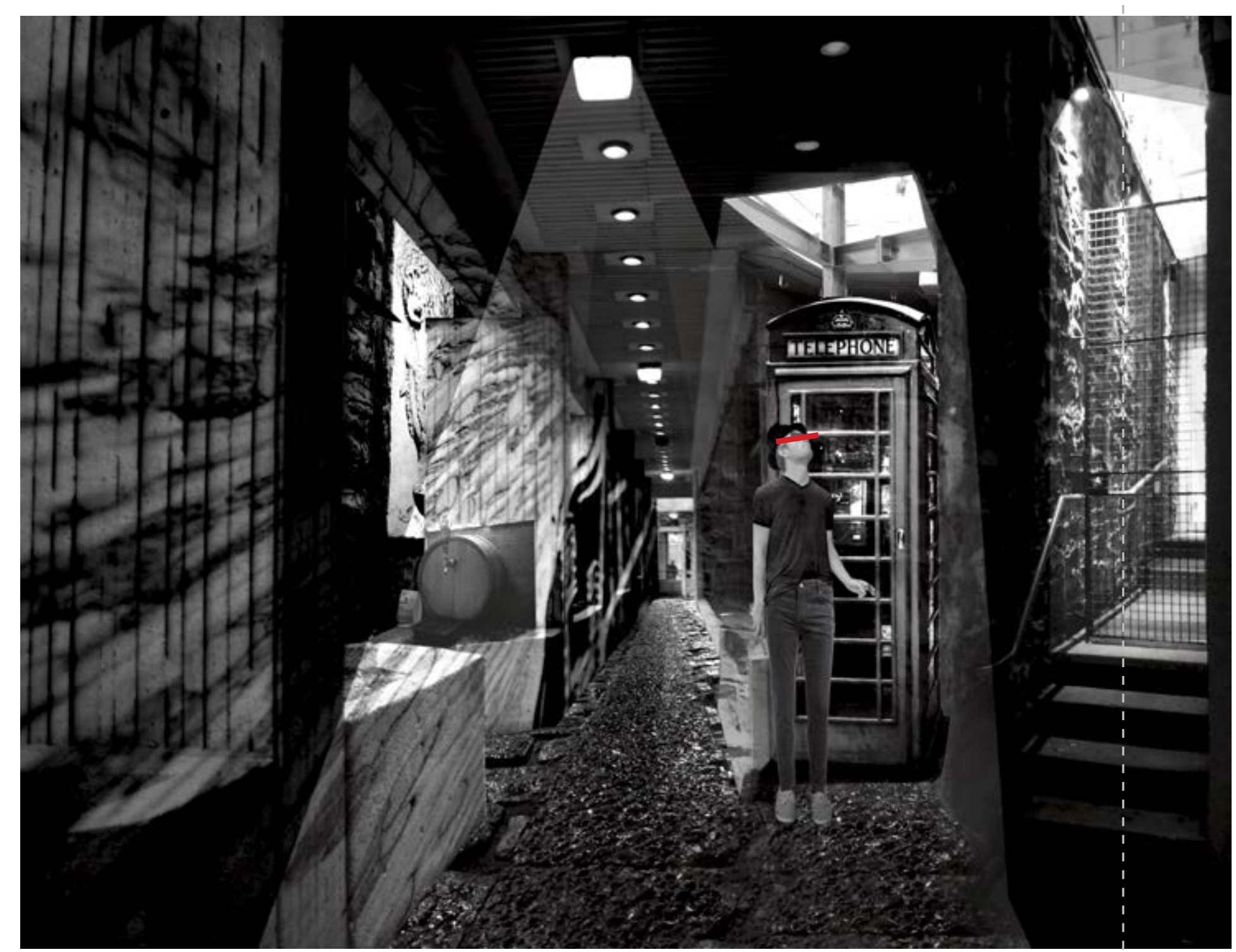

a "The first impression is not necessarily the reflection of reality"
Fold here

Allow the access into non official spaces through disguised entrances...

Vignettes: Hard treament of light, high contrast, sensorial experience

Section drawings: Emphasis on inhabitation through subversion,

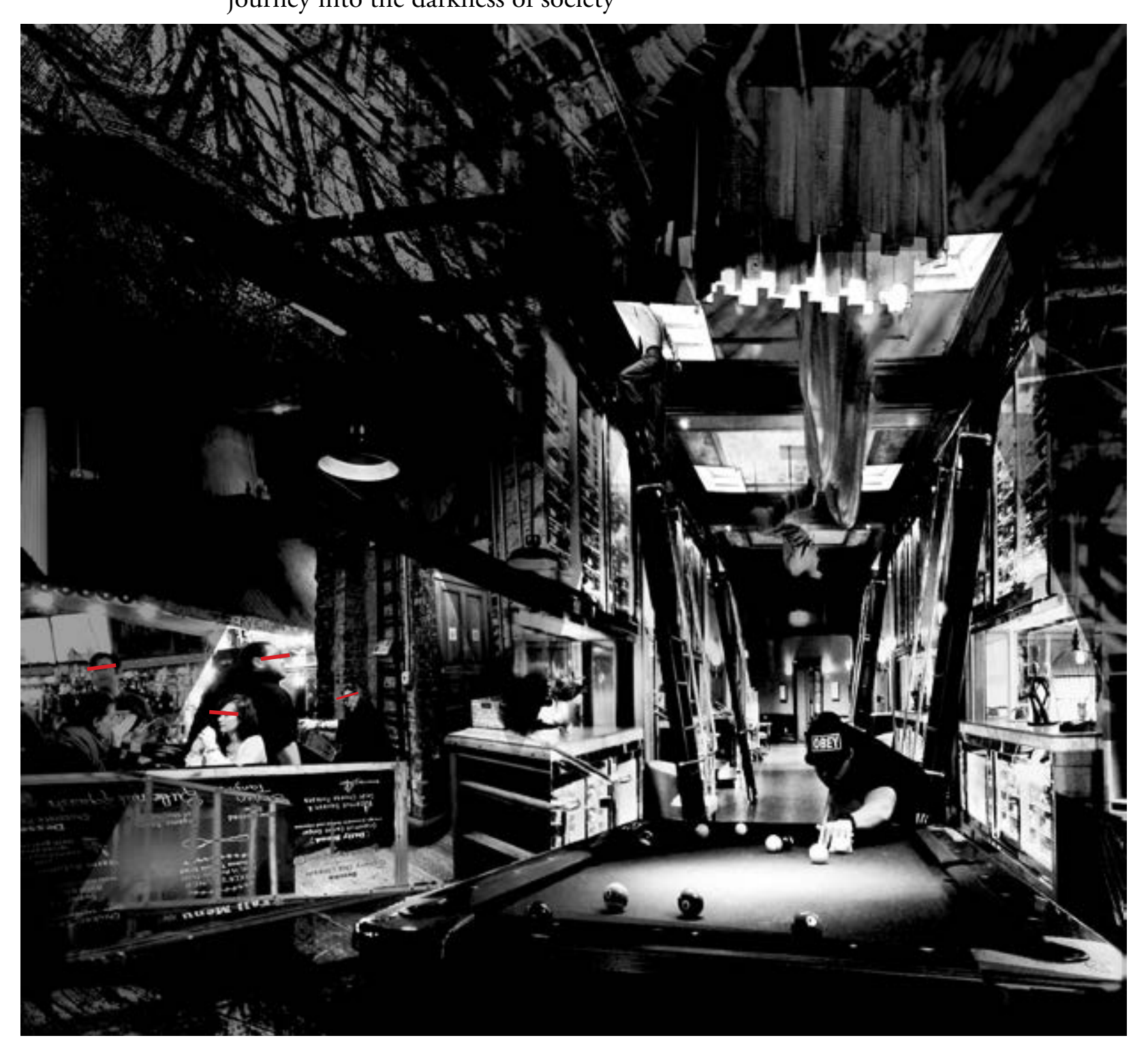

b Activities related to prohibition, activism, speakasies... 
INTERPROVINCIAL AFFAIRS

Québec 湀

\section{RED SCHEME - ANTI THESIS}

Illustration 66 Vignette 3

Compare the vignette with section 1

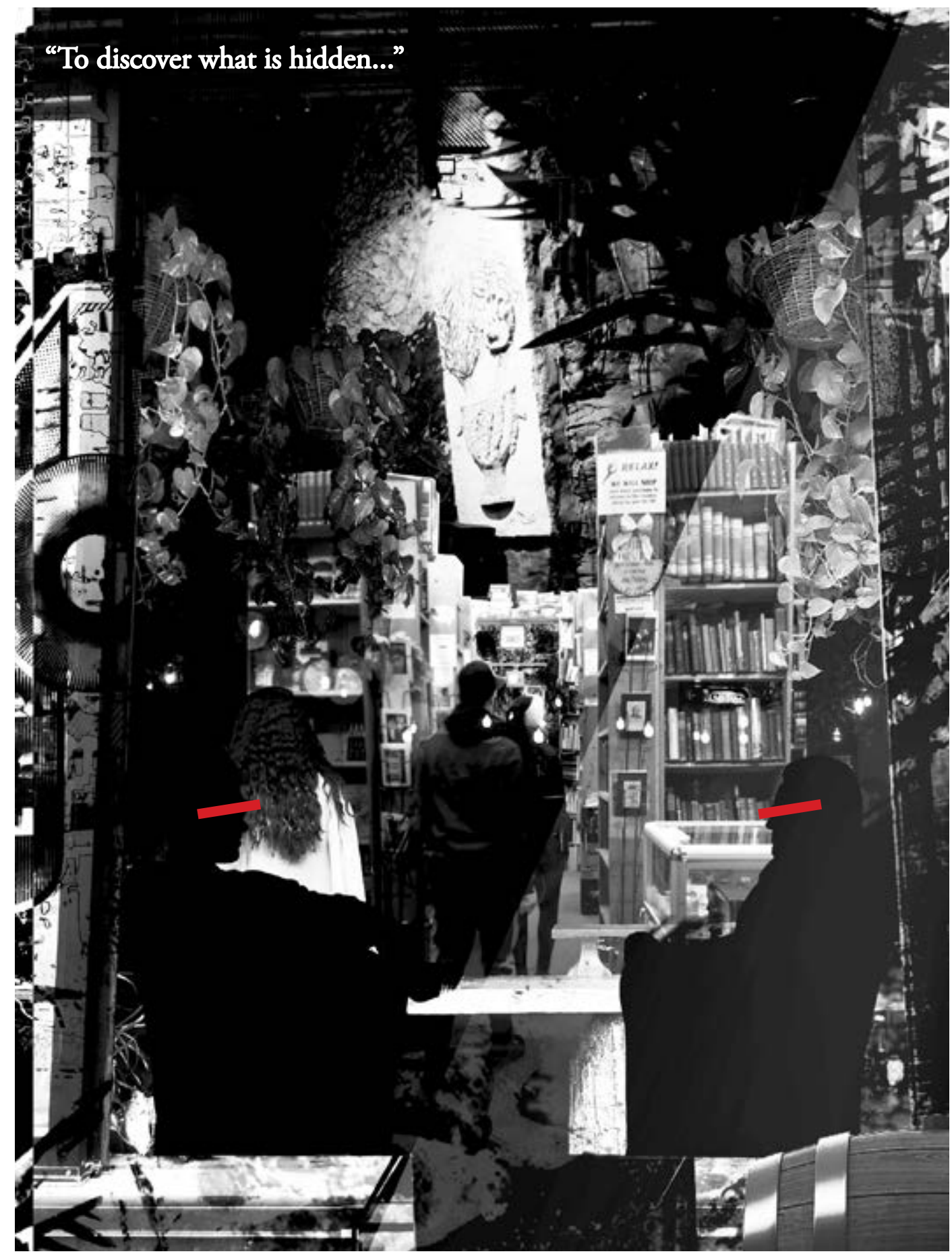




\section{INTERprovícial AFAars}

\section{RED SCHEME - ANTI THESIS}

\section{Illustrations $67 \mathrm{a}, \mathrm{b}$ Sections $2 \& 3$}

a The glass elevator penetrates through the atrium of Phase III (which connects to Place d'Accueil)

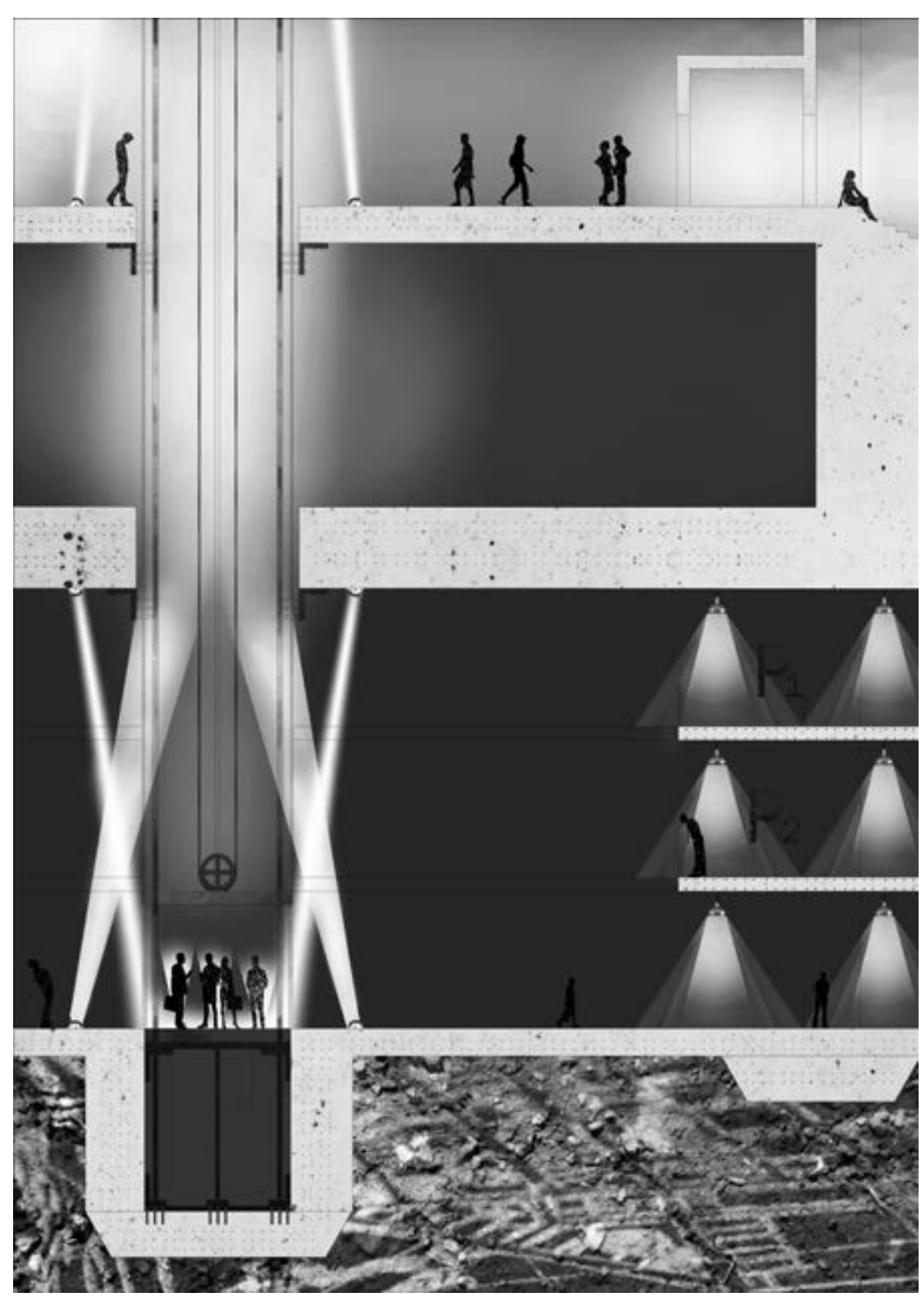

Fold here

"As you go deeper into the darkness, deeper in the underground of the Portage building, you get to an elevator. It has one stop; which is the top floor of the building (penthouse). This is the transition between the darkest depth (Section 2) of the building to its darkest moments (Section 3)."

"On this floor, most important persons of the government system are making most important decisions influencing our life, community and most importantly the relationship between Hull (provincial) and Ottawa (federal)."

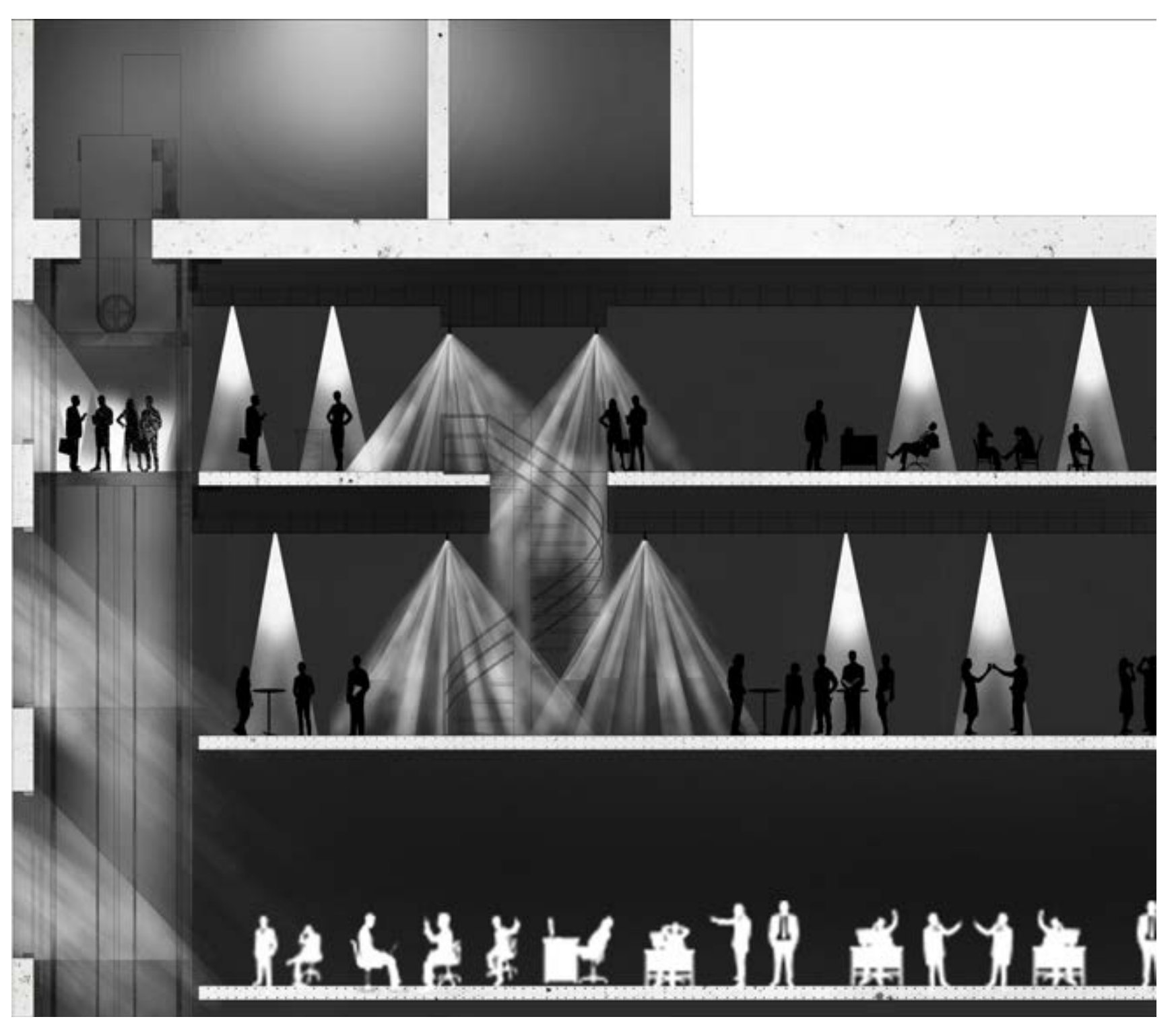

b Darkest moment of Portage buildings 


\section{INTERPROVINCIAL AFFAIRS \\ Québec 䳆}

\section{THE CITY OF SHADOWS - LA CITÉ DES OMBRES SYNTHESIS}

As per Confidentiality Agreement clause 87a this evidence cannot be shown to private consultant. This part relates to the "Classified " evidences in this report. Our organization cannot risk a breach of information.

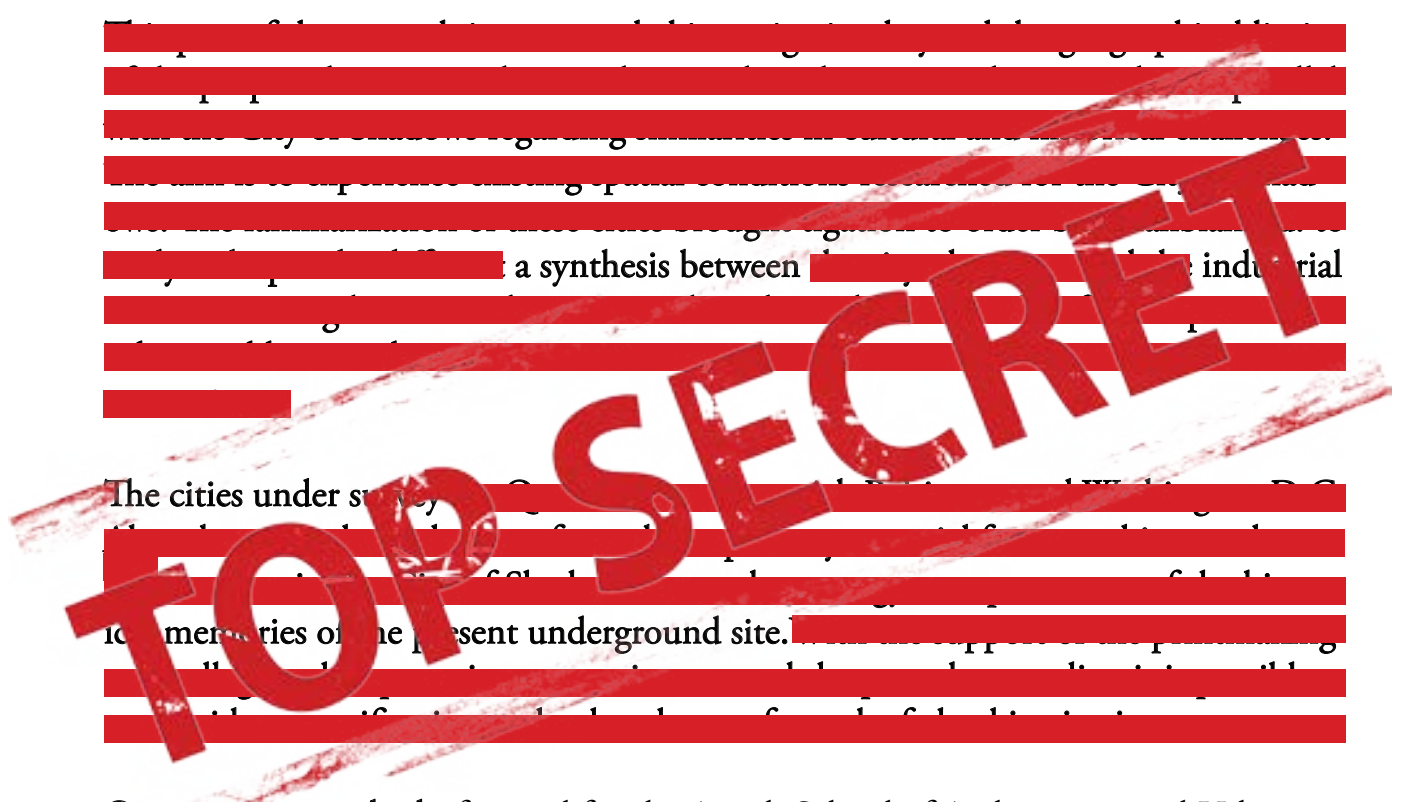

Our organization looks forward for the Azrieli School of Architecture and Urbanism to share their final recommendations.

Middle ground between OCCUPATION and CIRCULATION 


\section{INTERPROVINCIAL AFFAIRS \\ Québec 漝}

End of report.

Note: Burn document after reading as per Confidientiality Agreement clause 90. 


\title{
The City of Shadows - La Cité des Ombres
}

\author{
Bibliography
}

\section{Mise-en-scene Research}

Artaud, Antonin. The theater and its double. New York: Grove Press, 2004.

Brook, Peter. The empty space. London: Penguin Books, 2008.

Debord, Guy and Ken Knabb. The society of the spectacle. Berkeley, CA: Bureau of Public Secrets, 2014.

Lee, Pamela M., and Gordon Matta-Clark. Object to be destroyed: the work of Gordon MattaClark. Cambridge, MA: MIT Press, 2001.

Smith, Keri. The Wander society. NY, NY: Penguin Books, 2016.

\section{$\underline{\text { Historical Research }}$}

\section{BOOKS}

Boutet, Edgar. Le bon vieux temps à Hull : Tome II, notes historiques sur l'Outaouais. Hull : Gauvin, 1971.

Boutet, Edgar. Le bon vieux temps à Hull : Tome III, notes historiques sur l'Outaouais. Hull : Gauvin, 1971.

Gaboury, Étienne, and Faye Hellner. Étienne Gaboury. Saint-Boniface, Man., Manitoba : Éditions du Blé, 2005.

Hier, Sean P. Panoptic dreams: streetscape video surveillance in Canada. Vancouver, BC: University of British Columbia, 2011.

Lapointe, Pierre-Louis. L'île de Hull : une promenade dans le temps. Québec: Éditions GID, 2004.

Nemni, Max, Monique Nemni, and George Tombs. Trudeau transformed: the shaping of a statesman 1944-1965: volume two of Trudeau, son of Quebec, father of Canada. Toronto, Ontario: McClelland \& Stewart, 2013.

Rossignol, Léo, Pierre-Louis Lapointe, and Gaston Carrière. Hull, 1800-1975 : histoire illustrée. Hull, QC : Comité de la Grande fête de Hull, 1975.

Sean P. Hier, Panoptic Dreams: Streetscape video surveillance in Canada. UBC Press, 2011. 
Shorter, G. W. Ottawa-Hull Fire of 1900. Ottawa: National Research Council, 1962.

Taché, Louis-H. Le nord de l'outaouais; manuel-répertoire d'histoire et de géographie régionales; Ottawa, Ontario: Le Droit, 1938.

\section{NEWSPAPER}

Cleroux, Richard. “Place du Portage Project Rescued.” The Ottawa Journal, May 30, 1969.

Cleroux, Richard. “Unite Ottawa, Hull Destinies - Trudeau.” The Ottawa Journal, May 30, 1969.

Cleroux, Richard. “Quebec beat Gov't to draw on land." The Ottawa Journal, May 30, 1969.

Cleroux, Richard. "Relocation of E.B. Eddy Co. Being considered - Trudeau." The Ottawa Journal, May 30, 1969.

Mahaffy, Robert. “A longer life with less material.” The Ottawa Journal, November 18, 1972.

Metcalfe, Clarence. "Place du Portage "best thing could happen to Ottawa" - NCC." Place du

Portage "best thing could happen to Ottawa" - NCC, November 23, 1972.

Minton, Eric. “Bridging the years." The Ottawa Journal, June 17, 1972.

Nichols, Marjorie. “Opposition backs Hull plan.” The Ottawa Journal, May 30, 1969.

\section{ONLINE SOURCES}

“ETIENNE GABOURY DOES HULL.” Urbsite. Accessed Fall 2016. http:/ / urbsite.blogspot. ca/2014/01/etienne-gaboury-does-hull.html.

“HULL 1969-1995.” Urbsite. Accessed Fall 2016. http:/ / urbsite.blogspot.ca/2013/12/hull-19691995.html.

"Great Fire 1900". Accessed October 3rd, 2016. http:/ / outaouais.quebecheritageweb.com/article/great-hull-fire-1900

“Great Hull Fire of 1900." Great Hull Fire of 1900 | Outaouais Heritage WebMagazine. Accessed Fall 2016. http:/ / outaouais.quebecheritageweb.com/article/great-hull-fire-1900.

"Civilization.ca - Architecture of Old Hull - Fire Station - History". Accessed October 3rd, 2016. http://www.historymuseum.ca/cmc/exhibitions/hist/hull/rw_33_ie.shtml

Laquerre, Alexandre. “Ottawa past \& present." Holt Plan - Ottawa Past \& Present. Accessed Fall 2016. http://www.pastottawa.com/holt/.

Laquerre, Alexandre. “Ottawa past \& present." Hull - Ottawa past \& present. Accessed Fall 2016. http://www.pastottawa.com/quartier/hull/. 
Hallowell, Gerald. "Prohibition in Canada." The Canadian Encyclopedia. Accessed Fall 2016. http://www.thecanadianencyclopedia.ca/en/article/prohibition/.

Durocher, René. “Quiet Revolution.” The Canadian Encyclopedia. Accessed Fall 2016. http:/ / www.thecanadianencyclopedia.ca/en/article/quiet-revolution/.

"You never told who your bootlegger was". Accessed on October 2nd, 2016. http:/ / outaouais. quebecheritageweb.com/article/you-never-told-who-your-bootlegger-was

"Ottawa and Hull Relief Fund". Accessed on October 3rd,2016. https://archive.org/ details/ cihm_11661

"EB Eddy". Accessed on March 1st, 2017. http://workershistorymuseum.ca/category/eb-eddy/

"Hull et les Allumetières". Accessed on October 3rd, 2016. http:/ /www.reseaupatrimoine.ca/ cyberexpositions/les-tresors-du-patrimoine/hull-et-les-allumettes/e-b-eddy/

"Ezra Butler Eddy". Accessed March 1st, 2017. http://www.biographi.ca/en/bio/eddy_ezra_ butler_13E.html

"My encounter with the architecture of Old Hull". Accessed on October 1st, 2016. http://www. historymuseum.ca/cmc/exhibitions/hist/hull/introe.shtml

"A brief history of Le Petit Chicago". Accessed on October 1st, 2016. http:/ /www.petitchicago. ca/en/apropos

"The Bank Hotel". Accessed on October 2nd, 2016. http://www.historymuseum.ca/cmc/exhibitions/hist/hull/rw_15_ie.shtml

"Civilization.ca - Architecture of Old Hull - Fire Station - History." Civilization.ca - Architecture of Old Hull - Fire Station - History. Accessed Fall 2016. http://www.historymuseum.ca/cmc/ exhibitions/hist/hull/rw_33_ie.shtml.

"Canadian International paper company." CRAO - Centre régional d'archives de l'Outaouais. December 31, 2015. Accessed Fall 2016. http://craoutaouais.ca/canadian-international-paper-company/.

"Le Petit Chicago - A Bit of History." Le Petit Chicago - Urban Tavern. Accessed Fall 2016. http://www.petitchicago.ca/en/apropos.

“Urbsite - Hull's Post Office.” Urbsite. Accessed Fall 2016. https:/ / urbsite.blogspot. ca/2014_01_01_archive.html?view=classic.

“Reclaimed Wood from the Log Drive." Ecohome. Accessed Winter 2017. http:/ /www.ecohome. net/news/latest/reclaiming-sunken-timber-log-drive.

"1960 à nos jours - Moving towards sustainable development Vignette D3 The end of log-driving." Outaouais' Forest History - The end of log-driving. Accessed Fall 2016. http:/ / www. histoireforestiereoutaouais.ca/en/d3/\#1.

"Souvenir photo views of the big fire, Ottawa \& Hull, April 26th 1900 [microform] ." Internet Archive. Accessed Fall 2016. https://archive.org/details/cihm_01008. 
"Report of the Ottawa and Hull Fire Relief Fund, 1900 [microform] : Ottawa and Hull Fire Relief Fund ." Internet Archive. Accessed Fall 2016. https://archive.org/details/cihm_11661.

"A series of social and political events take place in Quebec, culminating in the October Crisis." Web Experience Toolkit. February 10, 2017. Accessed Winter 2017. http:/ / www.officiallanguages.gc.ca/en/timeline-event/a-series-of-social-and-political-events-take-place-in-quebec-culminating-in-the.

"Civilization.ca - Architecture of Old Hull - E. B. Eddy manufacturing building - History." Civilization.ca - Architecture of Old Hull - E. B. Eddy manufacturing building - History. Accessed Fall 2016. http://www.historymuseum.ca/cmc/exhibitions/hist/hull/rw_26_ie.shtml.

“E.B. Eddy Co." Workers' History Museum. Accessed Fall 2016. http:/ /workershistorymuseum. ca/portfolio/e-b-eddys-matches/.

“Category: EB Eddy.” Workers' History Museum. Accessed Winter 2017. http://workershistorymuseum.ca/category/eb-eddy/.

“Biography - EDDY, EZRA BUTLER - Volume XIII (1901-1910) - Dictionary of Canadian Biography." Home - Dictionary of Canadian Biography. Accessed Winter 2017. http:/ / www.biographi.ca/en/bio/eddy_ezra_butler_13E.html.

"Hull et les allumettes." Ezra Butler Eddy | Les trésors du Patrimoine. Accessed Fall 2016. http://www.reseaupatrimoine.ca/cyberexpositions/les-tresors-du-patrimoine/hull-et-les-allumettes/e-b-eddy/.

"Hull / EB Eddy Heritage Conservation District Plans - MTBA Architecture Urbanism Conservation." MTBA: Mark Thompson Brandt Architect \& Associates Inc. Accessed Fall 2016. http:/ / mtbarch.com/portfolio/hulle-b-eddy-heritage-conservation-district-plans/.

Brosseau, Marc, and André Cellard. "Un siècle de boires et de déboires : Hull aux prises avec son histoire et sa géographie." Érudit. April 08, 2004. Accessed Fall 2016. https:/ /www.erudit.org/ en/journals/cgq/2003-v47-n130-n130/007967ar/.

“E. B. EDDY MATCH FACTORY, HULL." E. B. EDDY MATCH FACTORY, HULL | Outaouais Heritage WebMagazine. Accessed Fall 2016. http:/ / outaouais.quebecheritageweb.com/article/eb-eddy-match-factory-hull. 


\title{
The City of Shadows - La Cité des Ombres
}

\author{
Appendices
}

Appendix A - Essay

La Place du Portage : Public courtyards \& the Panopticon effect

Appendix B - Essay

Printmaking: Exploration of digital and traditional techniques 


\section{Appendix A}

\section{INTRODUCTION}

"We shape our buildings; thereafter they shape us" - Winston Churchill

The Portage buildings in Hull, Québec, were built in the early 70's by Prime Minister Pierre-Elliott Trudeau to bring bilingualism across the Ottawa river. Federal work in the city would make Hull a national and provincial cultural landmark. It was meant to provide a new breath to Hull, a new identical sense with better conditions and aspirations. The effort was inefficacious; the Portage buildings are not attracting people and tourists across the Ottawa river as intended.

On week days, the officials leave hastily work by thousands, running away from their cubicles and routine; leaving Hull a husk of its daytime hustle. The courtyards are meant to be a transitional space to connect the office space with the public but instead the Portage buildings are disconnected from the rest of the urban fabric. A towering fortress of productivity whose inner courtyards are left dormant. These public spaces do not serve their purpose of social gathering as they should be. Even though there is no physical presence of monitoring, the monumentality of the governmental buildings leaves somehow an intimidating feeling of an omnipresent surveillance.

Architectural aesthetic and meaning of the Portage buildings will be discussed to understand the tensions between the government office buildings and the courtyards; these courtyards meant to be a public space throughout the complex.

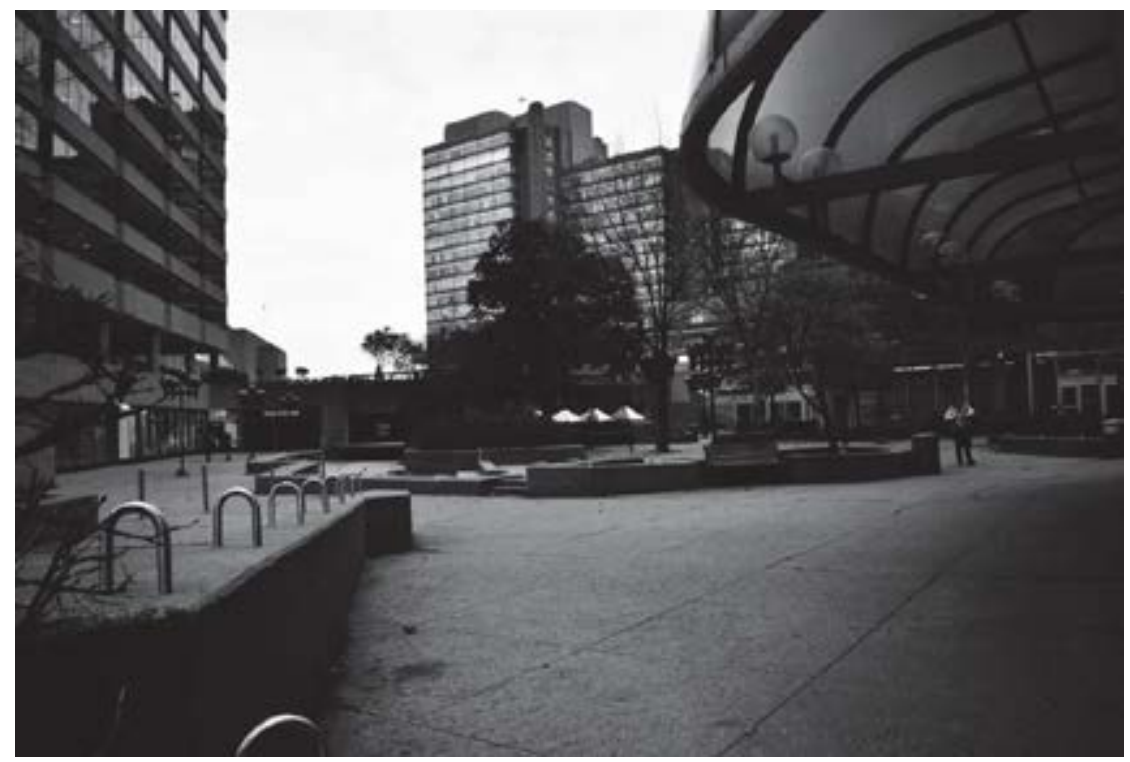

Place du Portage, West courtyard.

Photo credit : Alexandra Blanchet, 2017. 


\section{The Complex}

The four phases of the Portage buildings were built between 1973 and 1979. The federal buildings consist in a total of $232000 \mathrm{~m}^{2}$ of office space on a 12 acres' site near the Ottawa River shore line. ${ }^{1}$ The Franco- Manitoban architect Étienne Gaboury was commissioned by the National Capital Commission to conceptualize the complex.

\section{Materiality and Public Space}

The aesthetic follows a pure brutalist architecture. Each building has its own exterior concrete pattern to differentiate itself. The textured variations go from wood framework to heavy sandblast and corduroy. The roughness of the exterior concrete facade absorbs the moisture and turns black overtime, adding to the austerity of the complex. ${ }^{2}$ The space between the buildings are filled with courtyards, also made of concrete. The implementation of the federal buildings on these expropriated lands have asepticised the site, banning anything else to grow. The flow of pedestrian circulation is almost inexistent. Pedestrians prefer taking the longer route surrounding the government buildings instead of taking advantage of the shortcuts that the federal complex can offer through the urban fabric. The use of the same heavy material and brutalist architecture seem to repel the viewer, intimidated by the cold monumentality. The courtyards are designed to be a busy public space but are also conflicting with the program of the federal buildings that is highly secured and not allowing any kind of transparency on its activities. In Space: Social Product and Use Value, Henri Lefebvre describes well the idea of the space used as a political instrument:

"Space has become for the state a political instrument of primary importance. The state uses space in such a way that it ensures its control of places, its strict hierarchy, the homogeneity of the whole, and the segregation of the parts. It is thus an administratively controlled and even a policed space. ${ }^{\prime \prime 3}$

The federal buildings extend their power onto the public courtyards, regimenting a spatial condition devoted to urban freedom. Which destabilizes the assumption of heterotopia in a public space:

\footnotetext{
1 "La Place Du Portage." Place Du Portage. N.p., n.d. Web. Accessed Spring 2017. http://www.placeduportage.ca/ .

2 "Brutalism." Washington State Department of Archaeology \& Historic Preservation Protect the Past · Shape the Future. N.p., n.d. Web. 25 Apr. 2017. http://www.dahp.wa.gov/styles/brutalism .

3 "Space: Social Product and Use Value," Henri Lefebvre. In State, Space World: Selected Essays, p.188.
} 
"The heterotopia has the power of juxtaposing in a single real place different spaces and locations that are incompatible with each other." 4

In that regard, the concept of heterotopia by Michel Foucault is not compliant with the reality of the phenomenon happening in these courtyards. The element of power is fracturing the potentiality for social interaction. The viewer is aware of what can await for him if he chooses to walk through the courtyards. The transitions between the urban fabric, the federal buildings and the courtyards need to be more blended: The courtyards should act as a space of transition, a grey zone, without marking the territory between the office buildings and the neighborhood.

"... a function that takes place between two opposite poles. On the one hand they perform the task of creating a space of illusion that reveals how all of real space is more illusory, all the locations within which life is fragmented. On the other, they have the function of forming another space, another real space, as perfect, meticulous and well arranged as ours is disordered, ill-conceived and in a sketchy state." 5

The uncertainty of space is not inviting and thus not allowing complete freedom of movement. The exterior space can be seen as elitist, non-democratic, as it favors government officials to take advantage of the courtyards while it could also be adapted to the use of the neighborhood for different time of the day and week. "In acting and speaking, men show who they are, reveal actively their unique personal identities and thus make their appearance in the human world. " 6 Lack of these actions create only shadows, non-entirely existent "unique personal identities".

\section{$\underline{\text { An inverted Panopticon }}$}

Surrounding the public space, the countless office windows are overlooking on the courtyards, witnessing every single pedestrian passing through. The federal towering fortresses represent power

\footnotetext{
4 "Panopticism," Michel Foucault, from Discipline and Punish, in Rethinking Architecture, p. 334.

${ }^{5}$ Ibid, p. 335.

${ }^{6}$ Hannah Arendt and Margaret Canovan. The Human Condition. Chicago: U of Chicago, 2012, p. 179.
} 
and authority and they are acting as an "inverted" panopticon. The traditional panopticon proposed a, non-transparent, central tower of surveillance within a space, monitoring each cell or cubicle ${ }^{7}$ :

"It reverses the principle of the dungeon; or rather of its three functions - to enclose, to deprive of light and to hide... Full lighting and the eye of a supervisor capture better than darkness, which ultimately protected. Visibility is a trap." 8

In this case, four federal towers are looking over a central space where courtyards are intersecting at different elevations. The large scale and the political meaning of the buildings are constantly reminding the viewers that they are being watched.

"This enclosed, segmented space, observed at every point, in which the individuals are inserted in a fixed place, in which the slightest movements are supervised, in which all events are recorded, in which an uninterrupted work of writing links the centre and periphery, in which power is exercised without division, according to a continuous hierarchical figure, in which each individual is constantly located ..." 9

The Portage buildings consist in a function this disciplinary mechanism where the government officials are systematically assigned to a task on the specified floor, in a cubicle and must work without interruption from 9 a.m. to 5 pm., Monday to Friday.

This mechanism should reflect only the inside of the infrastructure, not the outside; to allow freedom to happen in the public spaces surrounded by the buildings. In this case, the exercise of blurring the lines between the urban fabric and the federal office buildings would bring the courtyards to their real use: a common ground where the public and private, the reveal and unreveal can coexist.

\footnotetext{
7 "Panopticism," Michel Foucault, from Discipline and Punish, in Rethinking Architecture, p. 340.

8 Idem.

9 "Panopticism," Michel Foucault, from Discipline and Punish, in Rethinking Architecture, p. 338.
} 


\section{CONCLUSION}

The Portage courtyards are not monitored nor protected by any security devices. At night, the exterior lighting is minimal which makes it easy for anybody to hide in the shadows. Not being able to locate a physical device of monitoring in the courtyards, at the ground level, makes the viewer question about him being watched anywhere from the federal towers; without being able to locate the observers.

The use of heavy material and oppressive surveillance does not allow the courtyard to achieve its purpose of public space. The courtyards are in fact lacking of welcoming elements to improve movement, circulation and transparency between the Portage buildings and its courtyards with the rest of the neighborhood. As Foucault says: "The liberty of men is never assured by the institutions and laws that are intended to guarantee them. ${ }^{10}$ It is crucial for public space to detach itself from the influence of the governmental apparatus.

Even the implementation of an illusion of safety within the space could attract people: the use of a different material such as wood and the scaling up of green spaces in the courtyards could be the perfect distraction to the panopticon phenomenon.

${ }^{10}$ Panopticism," Michel Foucault, from Discipline and Punish, in Rethinking Architecture, p.350. 


\section{BIBLIOGRAPHY}

\section{Books}

Arendt, Hannah, and Margaret Canovan. The Human Condition. Chicago: U of Chicago, 2012.

Lefebvre, Henri, Neil Brenner, Stuart Elden, and Gerald Moore. State, Space, World: Selected Essays. Minneapolis: U of Minnesota, 2010.

Leach, Neil. Rethinking Architecture: A Reader in Cultural Theory. London: Routledge, 2010.

Flowers, Benjamin Sitton. Architecture in an Age of Uncertainty. Farnham: Ashgate, 2014.

Sorkin, Michael. Indefensible Space: The Architecture of the National Insecurity State. New York: n.p., 2008.

\section{Online sources}

Anderson, Lamar. "Gensler Wants To Turn Doomed FBI Fortress Into A Futuristic Office Playground." Architizer. November 06, 2012. Accessed Spring 2017. http://architizer.com/blog/gensler-wants-to-turndoomed-fbi-fortress-into-a-futuristic-office-playground/.

"La Place Du Portage." Place Du Portage. N.p., n.d. Web. Accessed Spring 2017. http://www. placeduportage.ca/.

"Brutalism." Washington State Department of Archaeology \& Historic Preservation Protect the Past . Shape the Future. N.p., n.d. Web. 25 Apr. 2017. http://www.dahp.wa.gov/styles/brutalism .

"Anxious Architectures. The Aesthetics of Surveillance." Volume. N.p., n.d. Web. 25 Apr. 2017. http://volumeproject.org/anxious-architectures-the-aesthetics-of-surveillance/ . 


\section{Appendix B}

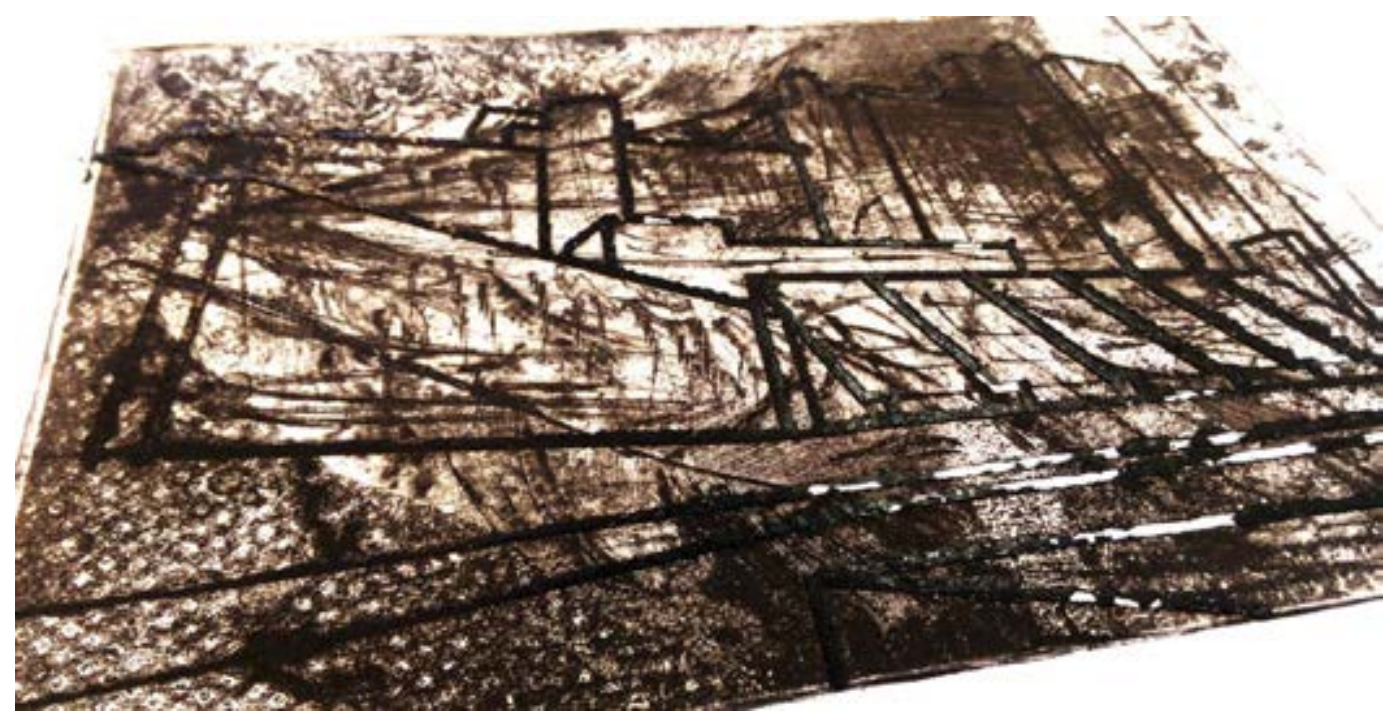

Figure 1. Zinc etching, black ink on paper.

Printmaking is the art or the technique of making prints, more specifically as performed traditionally in engraving, etching, dry point, woodcut or serigraphy. ${ }^{12}$ Printmaking methods range from simple to complex. With a variety of types and techniques, an artist can select the medium based on the kind of impression that they are looking to create. Modern printing technologies have evolved print making from the conventional processes. A few of these techniques include digital printing, photographic mediums and the combination of both digital and the conventional process. ${ }^{3}$ This paper will discuss the relationships between conventional and digital etchings on metal plate. First, it is relevant to understand how printmaking works to discuss its potential for mechanical reproduction and the understanding of its matrix, the image and the print.

${ }^{1}$ Oxford Dictionary

${ }^{2}$ Walter Benjamin, Hannah Arendt and Harry Zohn. Illuminations (New York : Harcourt, Brace \& World, 1968), 2.

${ }^{3}$ Abidin, Mursyidah Zainal, Daud Wan Samiati, Andriana Wan Mohd, and Mohd Razif Mohd Rathi. "Printmaking: Understanding the terminology," Procedia - Social and Behavioral Sciences 90 (2013): 407. 
The basic idea and advantage to the printmaking processes is the ability to make more than one specific image in a limited edition; the quantity of prints may be affected by the preciosity of the edition. ${ }^{45}$ The nature of printmaking requires that the entire edition to be printed simultaneously because the artist must print one colour at a time on each piece of paper. Prints are meant to be relatively inexpensive and many people can afford them which enhances the accessibility of the medium.

The term printmaking is referring to the process of making artwork by printing, normally on paper, which is called a print. ${ }^{6}$ The print is the imprint of a mark on a surface, produced by applying ink on a piece of paper. The terminology also refers to a mould into which a liquid substance is poured to set or cool in a desired shape. The use of matrix or mould in which a thing, an image, is cast or shaped can clearly relates to the print process itself. ${ }^{7}$

One can say that each piece is not a copy but an original since it is not a reproduction of another work of art and is technically understand as an impression. ${ }^{8}$ As mentioned, the original piece or the matrix is made by hand, as opposed to a reproduction which is made by a photomechanical method. ${ }^{9}$ One can also say that with the attempt to make visible the hand of the artist in an assertion of craft; printmaking like photography and other media has the potential for mechanical reproduction. ${ }^{10}$ "A remote experience must either extend the reach of the body and the body's senses, or assert that the divorce of body from medium is complete."11 Printmaking is a medium floating in a grey area of visual representation. The different techniques and tools used are redefining relationships between the matrix and the image, the original and the paper. For the case of metal etching in printmaking, everything starts with the

\footnotetext{
${ }^{4}$ Idem.

${ }^{5}$ Walter Benjamin, Hannah Arendt and Harry Zohn. Illuminations (New York: Harcourt, Brace \& World, 1968), 10.

${ }^{6}$ Abidin, Mursyidah Zainal, Daud Wan Samiati, Andriana Wan Mohd, and Mohd Razif Mohd Rathi.

"Printmaking: Understanding the terminology," Procedia - Social and Behavioral Sciences 90 (2013): 408.

${ }^{7}$ Oxford Dictionary

${ }^{8}$ Abidin, Mursyidah Zainal, Daud Wan Samiati, Andriana Wan Mohd, and Mohd Razif Mohd Rathi. "Printmaking: Understanding the terminology," Procedia - Social and Behavioral Sciences 90 (2013): 405.

${ }^{9}$ Walter Benjamin, Hannah Arendt and Harry Zohn. Illuminations (New York: Harcourt, Brace \& World, 1968), 17-18.

${ }^{10}$ Slaven, Michael. "Out of print," Afterimage 23 (1996): 5.

${ }^{11}$ Slaven, Michael. "Out of print," Afterimage 23 (1996): 5.
} 
creation of a drawing or a sketch that will be transferred on the plate with wax. It can also be done the other way around where the plate is entirely covered with wax, then directly etched freestyle on the plate. As the plate is being engraved, it removes the wax. The positive/negative space process starts here. The etching work will be properly "settled" through a chemical reaction with nitric acid; the metal plate is immersed in acid for a certain amount of time to obtain desired etch depth. What is cover by wax is not intended to be touched by the chemical reaction. This step is repeated as many times as needed, using different etching techniques to bring texture, lightness, darkness, depth into the piece.

The matrix or the metal plate acts as an intermediary with many characteristics; flat, hard and rigid surface containing a picture and/or message. The image receives ink and the inked image will transfer to the paper by pressure with a printing press. The result of the image is its mirror. What is etched or "carved out" from the plate is what will be shown on the paper. Depending on the depth and pressure from the printing press, a relief will appear on the impression. When the metal plate is completed, the printing process can be repeated many times with the same plate to produce almost exact copies, called an edition. Also, the versatility of the medium encourages variable editions. ${ }^{12}$

The print is "perhaps the ultimate work of simulation," and blurs the distinction between the virtual and the real. The processes that come between the artist's hand and the finished product raise the issue of authenticity, a key concept for a discussion of virtuality. ${ }^{13}$ In other words, without the intent, there is no real way to define if the print has been produced by hand or a product of mechanical reproduction.

Now that it comes to combine conventional and digital processes together, what happens to the status of the image and its authenticity, its potential for mechanical reproduction ${ }^{14}$ ?

The use of digital etchings adds another layer of complexity in the process. The steps of the process need to be calculated more precisely to ensure superimposition between hand and

\footnotetext{
${ }^{12}$ Abidin, Mursyidah Zainal, Daud Wan Samiati, Andriana Wan Mohd, and Mohd Razif Mohd Rathi. "Printmaking: Understanding the terminology," Procedia - Social and Behavioral Sciences 90 (2013): 409.

${ }^{13}$ Slaven, Michael. "Out of print," Afterimage 23 (1996): 6.

${ }^{14}$ Walter Benjamin, Hannah Arendt and Harry Zohn. Illuminations (New York: Harcourt, Brace \& World, 1968), 11.
} 
digital etchings. Digital etching on metal plate can be performed through a CNC machine; however, a lasercutter is not likely to work depending on the toxicity level and rigidity of the metal. Digital etching can perform any depth of cut into the metal and offers a very clean and structured engraving. The CNC machine will respond to a certain type of drawing, a specific file format, that will translate the line works into engraving movements, a matrix. The hand etching is left to the intuitive interpretation of an atmosphere, a feeling; the digital can offer a frame or a grid to that sensorial experience. At this point it can be suggested that the collaboration work between the hand tools and the CNC machine brings the matrix also on another level of complexity; it is doubled. The two matrices coexist together when they intersect but are also independent when they don't touch. Like a screen, a depth into the two-dimensional plate is being created. The negotiations between traditional and digital techniques vary depending on the printmaking techniques and the material of the plate. For example, it will be necessary for a hybrid woodcut to receive the digital etching or carving first to direct the hand carving. A uniform wood thickness is required to use digital equipment.

"In the woodcut, where the traces of the carving are impossible to obscure after the panel has been passed through the printing press. The physical, direct working process may be seen as a comment on the degrees of alienation in our own time. ${ }^{15}$

For a metal plate, no major part of the material is being removed as it is a finer type of etching; hand and machine can be mixed for a more versatile design. When one says "etching made by hand" it really refers the etching tools that the hand is using to do the work. With this hybrid technique, it is suggested that the creation of the image is a combination of two apparatuses; human and mechanical hands. Both apparatuses are performing the same program which the action of etching. ${ }^{16}$ However, there is some uncertainty in regard of the information; the print. The print is the mirror result of the image. Again, the image is the metal plate that was etched by a combination conventional and digital techniques. The print does not necessarily expose every little topographic details of the engraving; the print mostly captures the ink inscribed on the surface. ${ }^{17}$

\footnotetext{
${ }^{15}$ Kierulf, Caroline. "Printmaking and multiple temporalities." Journal of Visual Art Practice 14 (2015): 179-180.

${ }^{16}$ Vilém Flusser, Towards a Philosophy of Photography (England: Cromwell Press, 2000), 76.

${ }^{17}$ Ibid, 8.
} 
It is also suggested that hybrid printmaking can offer a potentiality for architectural exploration of space and sensorial experience: "The potential for dialogue between experiment, design and fabrication is now incredibly sophisticated. We can generate and manipulate geometries too complex to imagine without digital technology and then use that same technology to rationalise our designs." 18

There is no such thing as digital shortcut or substitute for talent or intelligent thinking. The appropriation of digital technologies as tools for design and fabrication may have given us great liberties in form-making but it comes with a lot of responsibility. The quality of a form can never replace the integrity and intent of a carefully developed concepts. It is crucial to preserve that connection between the hand and the brain; and printmaking is a way to preserve it. Being engaged with an etching tool on a horizontal surface, just like a pencil on a piece of paper, engages you in a different way from looking at a vertical screen. ${ }^{19}$

"When digital technologies are used with clever conceptual thinking and imagining, they are transformed from being merely tools. Innovation comes from harnessing this digital power with creative and intellectual rigour." 20

There are two aspects to consider; the intent and the difference between original prints and reproductions. If the work is conceived to be digital and printed as a digital work, it can be the same principle as using an etching plate or a wood block. The digital device becomes a matrix from which the prints find their origins and can be considered as original as prints created from a printing press. ${ }^{21}$ The digital work has to exist as the intended print; it is not to be confused with a photographic reproduction of already existing works such as painting or drawing. Printmaking has always been inclined to embrace new methods and technologies often evolving from other ends. This is one of many techniques that can provide a balance between reality and virtuality.

\footnotetext{
18 Levete, Amanda. "Fusing Digital Technology with the Hand-Made." Architects' Journal 233 (2011): 22.

19 Idem.

${ }^{20}$ Levete, Amanda. "Fusing Digital Technology with the Hand-Made." Architects' Journal 233 (2011): 23.

21 "Digital prints," last modified March 2013. http://www.markgraver.com/digital-prints/
} 


\section{BIBLIOGRAPHY}

\section{Primary}

Benjamin, Walter, Hannah Arendt and Harry Zohn. Illuminations. New York: Harcourt, Brace \& World, 1968.

Flusser, Vilém. Towards a Philosophy of Photography. England: Cromwell Press, 2000.

\section{Secondary}

Abell, Catharine. "Printmaking as an art." The Journal of Aesthetics and Art Criticism 73 (2015): 23-30.

Abidin, Mursyidah Zainal, Daud Wan Samiati, Andriana Wan Mohd, and Mohd Razif Mohd Rathi.

"Printmaking: Understanding the terminology." Procedia - Social and Behavioral Sciences 90 (2013): 405-10.

Anglesea, Martyn. Printmaking. In The Oxford Companion to Irish History. Oxford University Press, 2002.

Coldwell, Paul. "Hybrid practices within printmaking." Journal of Visual Art Practice 14 (2015): 175-178.

Graver, Mark. "Digital Prints." Last modified March 2013. http://www.markgraver.com/digital-prints/

Kierulf, Annette. "Printmaking and place." Journal of Visual Art Practice 14 (2015): 192-202.

Kierulf, Caroline. "Printmaking and multiple temporalities." Journal of Visual Art Practice 14 (2015): 17991.

Levete, Amanda. "Fusing Digital Technology with the Hand-Made." Architects' Journal 233 (2011): 22-23.

Slaven, Michael. "Out of print." Afterimage 23 (1996): 5-10.

Tierney, Therese. "Formulating Abstraction: Conceptual Art and the Architectural Object." Leonardo 40 (2007): 43-57.

Image

Alexandra Blanchet, City of Shadows: Study \#3,15cmX20cm, Zinc etching, black ink on BFK paper, 2017. 
The City of Shadows - La Cité des Ombres

END - FIN 